\begin{abstract}
UNIVERSIDADE DE SÃO PAULO
ESCOLA DE COMUNICAÇÕES E ARTES

PROGRAMA DE PÓS-GRADUAÇÃO EM CIÊNCIAS DA COMUNICAÇÃO (PPGCOM/ECA/USP)
\end{abstract}

ANA FLÁVIA MARQUES DA SILVA

A REDAÇÃO VIRTUAL E AS ROTINAS PRODUTIVAS NOS NOVOS ARRANJOS ECONÔMICOS ALTERNATIVOS ÀS

CORPORAÇÕES DE MÍDIA

SÃO PAULO

2019 


\title{
A REDAÇÃO VIRTUAL E AS ROTINAS PRODUTIVAS NOS NOVOS ARRANJOS ECONÔMICOS ALTERNATIVOS ÀS CORPORAÇÕES DE MÍDIA
}

Dissertação apresentada à Escola de Comunicações e Artes para obtenção do título de mestre em Ciências da Comunicação.

Versão Corrigida (versão original disponível na Biblioteca da ECA/USP)

Área de concentração: Teoria e Epistemologia da Comunicação

Orientadora: Professora Doutora Roseli Fígaro

\author{
SÃO PAULO
}


Autorizo a reprodução e divulgação total ou parcial deste trabalho, por qualquer meio convencional ou eletrônico, para fins de estudo e pesquisa, desde que citada a fonte.

Catalogação na Publicação

Serviço de Biblioteca e Documentação

Escola de Comunicaçōes e Artes da Universidade de São Paulo Dados inseridos pelo(a) autor(a)

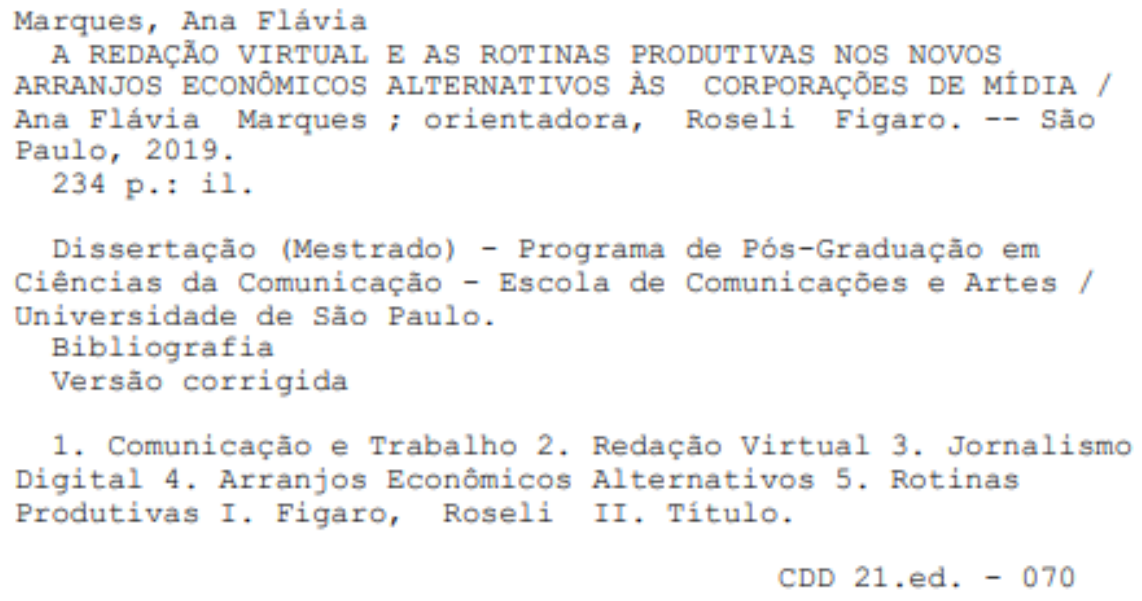




\section{Termos de Aprovação}

Nome do autor: Ana Flávia Marques da Silva

Título da dissertação: A redação virtual e as rotinas produtivas nos novos arranjos econômicos alternativos às corporações de mídia.

Presidente da Banca: Profa. Dra. Roseli Figaro

Prof. Dr. Instituição

Prof. Dr. Instituição

Prof. Dr. Instituição

Prof. Dr. Instituição 
O desenvolvimento dessa dissertação obteve apoio e financiamento do CNPq. 


\section{Agradecimentos}

Agradeço ao Conselho Nacional de Desenvolvimento Tecnológico (CNPq) pelo apoio e financiamento da pesquisa. À Coordenação de Aperfeiçoamento de Pessoal de Nível Superior (CAPES) pelo suporte às atividades científicas.

Fazer pesquisa está longe de ser uma atribuição solitária. Em tempos de tentativa de rebaixamento da ciência, agradeço ao Centro de Pesquisa em Comunicação e Trabalho da ECA-USP pelo acolhimento e estímulo para buscar respostas e questionar os pensamentos deterministas. À Cláudia Nonato, Rafael Grohmann, Camila Acosta, João Augusto Moliani, Jamir Kinoshita, Fernando Pacchi, Cláudia Rebecchi, Naiana Rodrigues, Michele Roxo, Janaina Visibeli meus agradecimentos. Aos bolsistas de iniciação científica Amanda, Will e Janaína, meus agradecimentos pela companhia no cotidiano.

À Profa. Roseli Figaro, mais do que orientadora, foi uma companheira terna, fraterna e serena, mas não menos rigorosa, que nos conduziu em todos os embates teóricos, metodológicos e existenciais mostrando na prática como vencer o pessimismo da razão com o otimismo da vontade, como bem formulou Antonio Gramsci em seu livro Cadernos do Cárcere.

À minha mãe, Gesana Oliveira, por me ensinar a lutar por uma vida melhor e às minhas irmãs, Andreia, Adriana e Isabelly, e ao meu padrasto Wagner, por compreender as ausências nas datas comemorativas. Do mesmo modo, agradeço ao meu companheiro de vida, Marcelo Cardia, por me estimular e acompanhar durante toda a jornada acadêmica, trocar o lazer e o descanso pela discussão sobre o Brasil, os pensamentos sobre comunicação e a euforia das novas descobertas.

Agradeço ao Altamiro Borges por seu exemplo de amplitude e todos os membros do Centro de Estudos da Mídia Alternativa Barão de Itararé por insistir que é preciso democratizar a comunicação, especialmente às "baronesas" Cláudia Rocha, Larissa Gould, Érica Aragão e Célia Medina por tanta camaradagem.

À Mayara Vasconcelos, ao Hobert dos Santos, Bruno Prado, André Gomes e Benito Vásquez agradeço ao incentivo à concentração e as risadas dos textos que ainda buscavam nexo. 
"O sistema neoliberal procura neutralizar o pensamento crítico, reduzir o espaço para ideias alternativas e contestadoras, ainda que estas continuem se manifestando, resistindo e reiventando-se."

(Denis de Moraes, 2013)

"Quando pensávamos ter todas as respostas, de repente, mudaram todas as perguntas."

(Mario Benedetti) 


\section{Resumo}

Marques, Ana Flávia. A redação virtual e as rotinas produtivas dos arranjos econômicos de comunicação alternativos às corporações de mídia. 2019. Dissertação (Mestrado em Ciências da Comunicação) - Escola de Comunicações e Artes, Universidade de São Paulo. São Paulo.

O objetivo desta dissertação é analisar as relações de comunicação e trabalho dos jornalistas em arranjos econômicos alternativos às corporações de mídia e compreender como é produzida a matéria jornalística desde a seleção da pauta até a sua publicação, bem como apreender os espaços constituintes dessa produção, o financiamento e os sentidos sobre jornalismo em quatro veículos: Agência Pressenza, Jornalistas Livres, Opera Mundi e Outras Palavras. Ao empregar o binômio comunicação e trabalho na pesquisa junto com o ponto de vista do trabalho da Ergologia identificamos novas formas de organização do trabalho. Essas mutações acontecem em um espaço próprio que denominamos como 'redação virtual'. É neste ambiente em que as relações de trabalho do jornalista são moduladas e padronizadas, sendo também o local possível para se observar como os jornalistas constroem valor de uso e de troca; como se dão as novas formas culturais das relações de produção; os valores mobilizados para o trabalho e o que levam do trabalho para a sociedade. Na dialética do trabalho há, em um lado a precarização estrutural das relações, porém, no outro a busca por saídas para produzir um jornalismo independente e garantir diversidade e pluralidade de informação. As tensões advindas desse cenário e o uso central de tecnologias de informação e comunicação evidenciam novos enquadramentos profissionais na área da comunicação e as tensões na deontologia do jornalismo, principalmente na Teoria Newsmaking e Gatekeeping.

Palavras-chave: Comunicação e Trabalho. Jornalismo. Redação Virtual. Mídia Alternativa. Arranjos Alternativos. 


\begin{abstract}
Marques, Ana Flávia. The virtual newsroom and productive routines of alternative economic communication arrangements for media corporations. 2019. Dissertation (Master in Communication Sciences) - Escola de Comunicações e Artes - Universidade de São Paulo. São Paulo

The aim of this dissertation is to analyze the relations of communication and work of journalists in alternative economic arrangements to the media corporations and to understand how journalistic material is produced from the selection of the agenda until its publication, as well as to apprehend the constituent spaces of this production, funding and senses on journalism in four vehicles: Pressenza Agency, Free Journalists, Opera Mundi and Other Words. By employing the binomial communication and work in research together with the work point of view of Ergology we identified new forms of work organization. These mutations happen in a space of their own that we call 'virtual writing'. It is in this environment where the journalist's working relationships are modulated and standardized, and it is also the possible place to observe how journalists build use and exchange value; how the new cultural forms of production relations take place; the values mobilized for work and what they take from work to society. In the dialectic of work there is, on the one hand, the structural precariousness of relationships, but on the other, the search for ways out to produce independent journalism and to guarantee diversity and plurality of information. The tensions arising from this scenario and the central use of information and communication technologies show new professional frameworks in the area of communication and the tensions in journalistic ethics, especially in Newsmaking and Gatekeeping Theory.
\end{abstract}

Keywords: Communication and Work. Jornalism. Virtual Newsroom. Alternative Media. Alternative Arrangements. 


\section{Lista de Tabelas}

Tabela 1 - Caminho da produção jornalística Agência Pressenza .................................97

Tabela 2 - Títulos coletados na amostragem ...................................................... 100

Tabela 3 - Levantamento feito pela autora a partir de declaração dos 62 membros em questionário on-line

Tabela 4 - Caminho da produção da matéria jornalística .......................................... 119

Tabela 5 - Caminho da produção jornalística no Opera Mundi................................. 141

Tabela 6 - Caminho da produção jornalística no Outras Palavras .............................. 158

Tabela 7 - Relação de matérias coletadas no arranjo ............................................ 162 


\section{Lista de ilustrações e gráficos}

Figura 1 - Lista do interfone do Ateliê do Bixiga no início da pesquisa ....................... 32

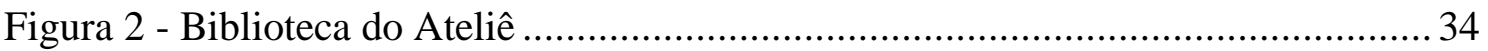

Figura 3 - Os espaços e horários comuns, como o almoço são os momentos de troca... 35

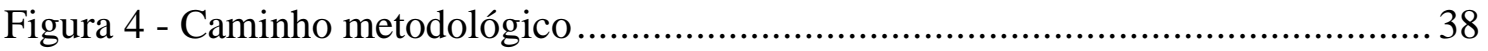

Figura 5 Organograma da Agência Pressenza Internacional de Notícias ..................... 84

Figura 6 - Cartaz da Agência Pressenza que é colocado em escolas técnicas e universidades

Figura 7 - Arte para site e redes sobre a campanha em torno do Manual .................... 87

Figura 8 - Cartaz distribuído em escolas e universidades que visava ação eleitoral ......90

Figura 9 - Organograma da organização do Agência Pressenza Brasil ........................ 90

Figura 10 - Trabalho improdutivo e produtivo...................................................... 94

Figura 11 - Livros e a fotografia de Silo ficam em lugar de dessaque na sede da Agência98

Figura 12 - Reunião de pauta presencial dos Jornalistas Livres no Ateliê do Bixiga.. 103

Figura 13 - Imagem coletada na observação da redação virtual ............................... 110

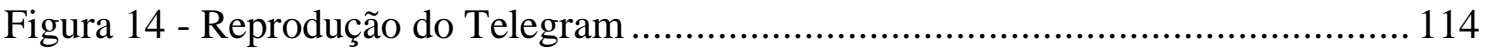

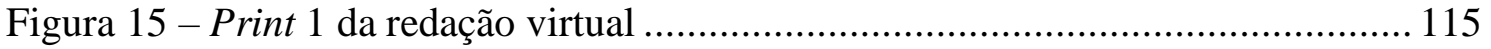

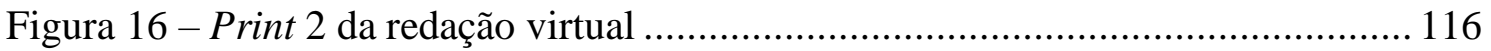

Figura 17 - Print 3 da redação virtual ................................................................ 116

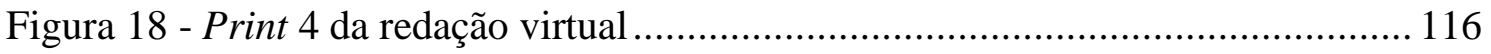

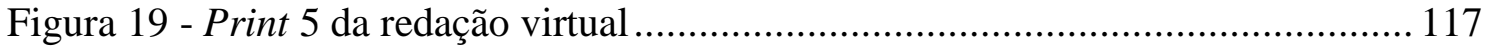

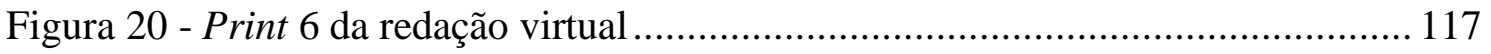

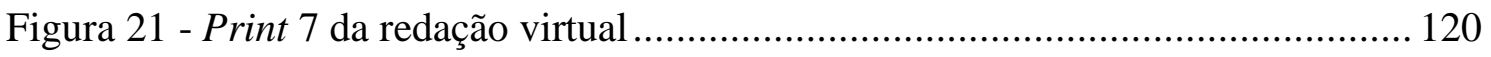

Figura 22 - Organograma do Opera Mundi ............................................................ 139

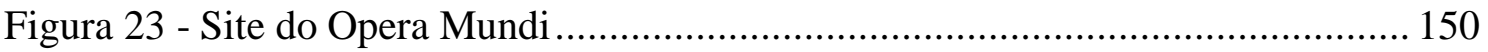

Figura 24 - Nuvem de palavras mais usada....................................................... 151

Figura 25 - Organograma de trabalho do Outras Palavras ....................................... 154

Figura 26 - Reprodução do site Outras Palavras..................................................... 161

Figura 27 - Fotografia da organização do site ........................................................... 162

Figura 28 - Nuvem de Palavras-chave encontradas nas matérias coletadas ................ 163 


\section{Sumário}

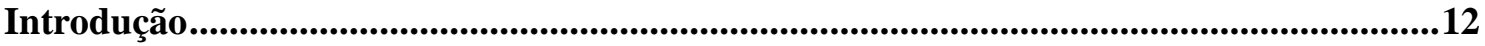

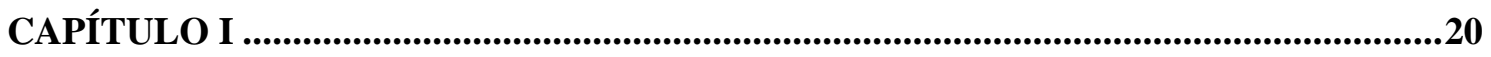

Além da aparência: a construção do objeto de análise .................................................................20

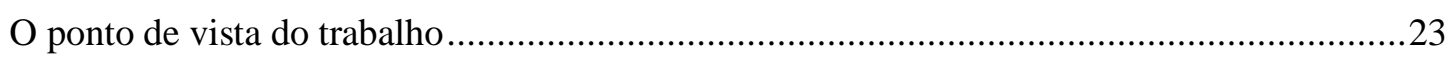

Uma triangulação da linguagem sobre/como/no trabalho .....................................................28

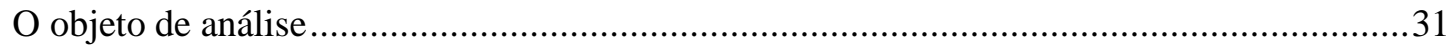

Conselheiro Ramalho, 945 - Ateliê do Bixiga .....................................................................................34

Combinação de técnicas utilizadas na pesquisa.............................................................................37

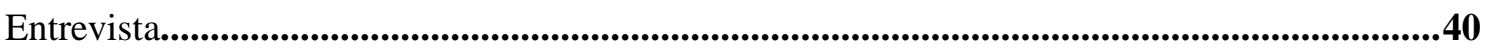

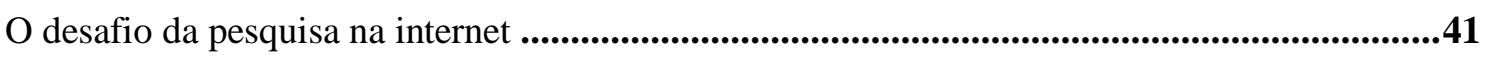

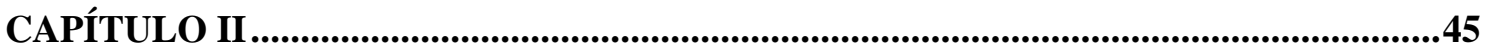

Mídia alternativa: um olhar histórico dacontra-hegemonia na comunicação............................45

O conceito de comunicação alternativa do ponto de vista histórico e social ...........................46

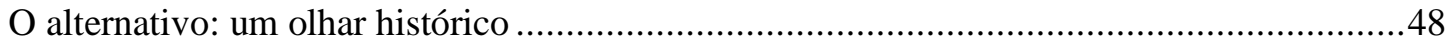

Imprensa anarquista e imprensa operária ….................................................................5

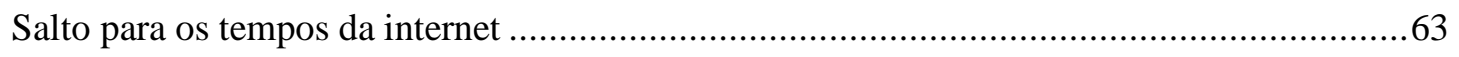

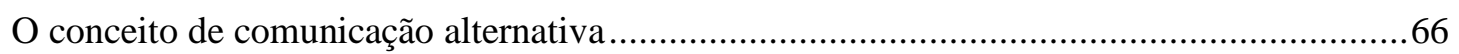

_O alternativo como um conceito "sede" ..................................................................................68

O conceito de hegemonia e a teoria dos Estudos Culturais ................................................... 71

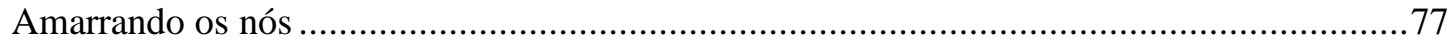

Capítulo III ..........................................................................................................................................8

Os arranjos alternativos de comunicação do Ateliê do Bixiga..............................................81

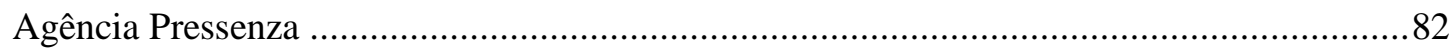

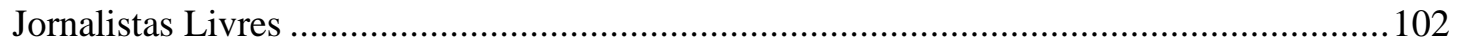

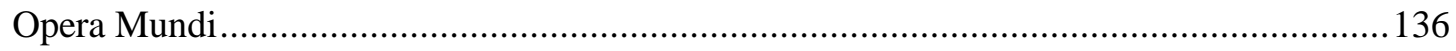

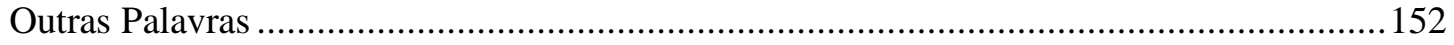

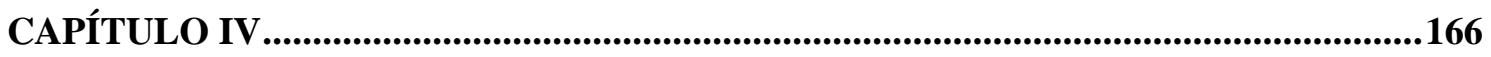

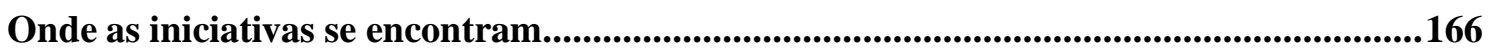

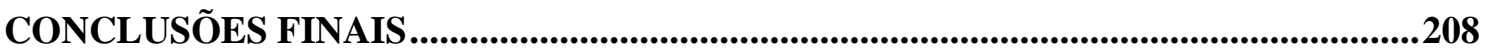

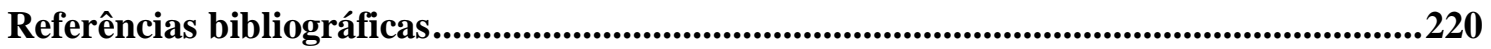




\section{Introdução}

O objetivo central dessa pesquisa é aprofundar como se dão as relações de comunicação no trabalho dos jornalistas que atuam em arranjos de comunicação alternativos às corporações monopolizadas e oligopolizadas de mídia. Ancoradas no objetivo principal, outras questões secundárias complementaram nossa análise como, por exemplo, as relações de produção, a descrição do processo desde a seleção da pauta até a elaboração final do discurso, as noções e pilares do jornalismo acionados para construção da matéria e, por fim, quais as relações e recursos mobilizados para garantir o financiamento desses sites.

As relações de comunicação nesses arranjos alternativos se dão de forma diferente daquelas que tratam o discurso jornalístico como mercadoria e têm como objetivo principal o capital, o lucro de suas atividades.

O jornalismo feito pelos arranjos é encarado como forma de conhecimento do cotidiano, como um espaço comum que serve de referências para formulação de outras informações e opinião acerca de acontecimentos e fatos.

Nossa análise esteve inserida no curso da primeira fase de pesquisa realizada pelo Centro de Pesquisa em Comunicação e Trabalho $(\mathrm{CPCT})^{1}$, denominada As relações de comunicação e as condições de produção no trabalho de jornalistas em arranjos econômicos alternativos às corporações de mídia. $O$ fator que nos diferencia e dá especificidade é o de aprofundar aspectos levantados na investigação coletiva.

Diante disso, adotamos o conceito de "arranjos econômicos alternativos" (FIGARO, 2018, p. 17) para nos referir aos veículos de comunicação que contavam com mais de três pessoas na produção dos materiais jornalísticos. Essa nomeação destaca a “[...] possibilidade de micros e pequenas empresas, organizações não governamentais, organizações da sociedade civil, coletivos e outros grupos de trabalhadores da comunicação e do jornalismo que possam representar efetiva alternativa de trabalho e emprego" (ibidem, p. 19).

Já para o Serviço Brasileiro de Apoio às Micro e Pequenas Empresas (Sebrae), que tem como uma das áreas prioritárias de atuação os negócios de mídia e comunicação, o arranjo produtivo é definido “[...] como uma aglomeração de empresas com especialização

\footnotetext{
${ }^{1}$ Pesquisa financiada pela Fundação de Amparo à Pesquisa do Estado de São Paulo (Fapesp). Processo 16/06992-3. Acesse em http://www.bv.fapesp.br/pt/auxilios/94453/as-relacoes-de-comunicacao-e-as-condicoesde-producao-no-trabalho-de-jornalistas-em-arranjos-economi/
} 
produtiva e vínculos de articulação, interação, cooperação e aprendizagem entre si e com outros atores locais" (CARDOSO, 2014, p. 7).

Em artigo sobre arranjos alternativos de trabalho, Spreitzer, Cameron e Garret (2017, p. 477) adicionam à classificação de alternativo de Capelli e Keller (2013) a flexibilidade na relação de trabalho, na programação do trabalho e na localização onde o trabalho é realizado a partir da concepção que o trabalho alternativo está relacionado ao controle da empresa das atribuições do trabalhador - "como e o que ele faz" - e o contrato, onde, em tese, o trabalhador teria controle para decidir como é seu trabalho.

Mais do que forma jurídica de relação de trabalho, os arranjos alternativos dos jornalistas são espaços de sobrevivência, de arranjar formas criativas para desenvolver a atividade de comunicação e, embora muitos deles não sejam remunerados, têm condições de ofertar conteúdo informativo para regiões e cidades que não possuem nenhuma fonte de informação sobre suas realidades. Nesse "arranjar" cabe a constituição de empresas, associação, conjunções de microempreendedor individual ou outras formas não prescritas que sustentam a produção noticiosa.

Além do conceito emprestado de arranjos econômicos alternativos, utilizamos a investigação do CPCT como suporte teórico, empírico e como trânsito de ideias entre a análise coletiva e esta pesquisa. Absorvemos informações como as formas de financiamento, o uso de alternativo e independente, o trabalho de categorização dos arranjos e núcleos diferentes, a definição de marcadores jornalísticos utilizados pelos próprios veículos e, principalmente, quem faz a mídia alternativa e os contextos em que estão inseridas as pessoas que realizam essa atividade que tanto contribui para a sociedade.

No Capítulo I, explicitamos as operações teóricas e metodológicas com a perspectiva do binômio comunicação e trabalho (FIGARO, 2018) como duas faces do mesmo movimento dialético, o qual tem como base o vínculo entre a ontologia do ser social (MARX; ENGELS, 2007, LUKÁCS, 2012) e o conceito de ergologia (SCHWARTZ; DURRIVE, 2008), que considera o trabalho como uma atividade humana sempre inédita, cuja utilização pressupõe o ponto de vista do trabalho, as normas prescritas e a renormatização derivada da prática inovadora à qual as relações de comunicação são determinantes porque o trabalho é sempre coletivo. 
Segundo Leontiev (2004, p. 92), trabalho e comunicação formam um processo único, sendo que "[...] no trabalho os homens entram forçosamente em relação, em comunicação uns com os outros." Nessa perspectiva, o ponto de vista do trabalho foi apreendido através também da atividade linguageira, que explora os sentidos da linguagem sobre, no e como trabalho (NOUROUDINE, 2002, grifo nosso).

O corpus de análise definido teve como critério o princípio da diversificação que podemos apreender em um mesmo espaço físico, como é o caso dos arranjos que são sediados no Ateliê do Bixiga, espaço compartilhado de trabalho que, no início da pesquisa, agregava veículos de comunicação, editoras, escritório de advocacia, um restaurante e duas empresas de produção de eventos. Dentro da casa, selecionamos os veículos de comunicação para compor a análise, sendo eles: Agência Pressenza, Jornalistas Livres, Opera Mundi e Outras Palavras.

Através da etnografia e da observação participante trouxemos à superfície aspectos das relações de comunicação e do trabalho dos jornalistas, da construção narrativa da mídia alternativa, das formas criativas de organização de iniciativas que almejam contribuir com a sociedade ao buscar a função social da comunicação.

Em entrevista à Revista Matrizes, Jesús Martín-Barbero (2009, p. 147) defendeu que a “[..] universidade está deslocada da sociedade [...]” e que, comparando-a com outros tempos, havia a capacidade de propor iniciativas e alternativas em uma discussão em que o "[...] país estava sempre no centro da mesa."

Por isso, refletir sobre as lacunas que existem no tratamento do tema desses novos arranjos de comunicação, compreender a sua lógica e dinâmica de produção e as relações de trabalho é pensar também o país, as suas estruturas dominantes e quem faz a contraposição para construção, através da comunicação, de uma sociedade mais democrática. Assim, acreditamos seguir uma importante orientação de Martín-Barbero sobre a produção de conhecimento em que ele diz ser “[...] preciso colocar o país na pesquisa em comunicação, é preciso colocá-lo na pesquisa em ciências sociais.” (ibidem)

Temos noção de que a posição a que nos associamos com esta pesquisa dentro do campo da comunicação está longe de ser caracterizada como dominante. Contudo, é preciso ter consciência da disputa e provocar as tensões necessárias para que o levantamento de aspectos, discussão sobre esses fenômenos existam sob o ponto de vista científico. 
No Capítulo II, evidenciamos como o contexto é importante por exprimir a materialidade da luta política que esses novos arranjos buscam ao se contraporem aos conglomerados de mídia. Nesse sentido, podemos citar a fundação da Revista Fórum, que aconteceu como fruto da narrativa contra o Fórum Econômico de Davos e a favor do primeiro Fórum Social Mundial (2001); a Revista Caros Amigos (1997), criada para denunciar as privatizações da ofensiva neoliberal, proposta pelo então presidente Fernando Henrique Cardoso (1995-2002); os diversos sites e blogs criados com o aumento do serviço de internet, mas também após 2002, primeiro ano de governo do ex-presidente Luiz Inácio Lula da Silva; e a recente fundação dos Jornalistas Livres, fruto de um plano de cobertura das manifestações pró e contra impeachment da ex-presidente Dilma Rousseff, entre outros exemplos de arranjos que podem ser relacionados no cenário político e econômico brasileiro.

Esse fenômeno não é novo. Apontamos a influência da categoria geral e particular do movimento dialético que intervém na formação de experiências de comunicação alternativa ao longo da história do Brasil. São exemplos que demonstram que a análise das relações de produção pode agregar vários veículos de comunicação sob o mesmo conceito-sede de "comunicação alternativa", onde mais do que descrever sobre tipologia de mídia, trata-se de um sentido que busca, através da disputa social, constituir-se como força contra-hegemônica.

Mesmo havendo o crescimento de estudos acerca dos novos arranjos, existem lacunas que carecem de estudo em busca de aprofundar o conhecimento dos fenômenos desses meios de comunicação em facetas ainda não exploradas, como as relações de comunicação e trabalho.

No Capítulo III, sistematizamos e realizamos já alguns nexos analíticos, identificando categorias que emergiram do próprio processo de pesquisa. Descrevemos como os quatro veículos (Agência Pressenza, Jornalistas Livres, Opera Mundi e Outras Palavras) foram criados; analisamos o jornalismo produzido; como se dá o caminho da pauta até a publicação; e como o trabalho é organizado com o uso das tecnologias de informação e comunicação (TICs).

Diferentemente de como a historiografia dominante sobre os veículos de comunicação retrata, a mídia comercial não é a única que faz a mediação com a sociedade. As TICs, ao mesmo tempo que proporcionam aos novos arranjos a possibilidade de produção de conteúdo jornalístico, facilitam também a organização do trabalho dos jornalistas. Se antes o profissional não tinha esse elemento de apoio e facultativo diante das práticas de assédio, cerceamento da liberdade de expressão, entre outros sintomas da relação entre capital e trabalho, atualmente a possibilidade de 
construir ou participar de um arranjo alternativo é muito mais próxima e real, embora também tenha muitas dificuldades como veremos ao tratar sobre financiamento.

No contexto da crise que assola diferentes instituições, as próprias noções de jornalismo estão em movimento e o crescimento do jornalismo nas plataformas digitais contribui com o tensionamento das convenções e normatizações na prática da produção da forma discursiva.

Ao tratarmos das formas discursivas, é importante ressaltar que, para compreendermos o movimento dialético da linguagem, destacamos seus elementos estruturais: enunciado, enunciação, discurso, condições de produção e sujeito enunciador. Esses princípios evidenciam a vivacidade e a dinâmica da linguagem e a faz, como espelho do mundo, refletir e refratar o pensamento e o conhecimento humanos (VOLOCHINOV/BAKHTIN, 2014). A análise do discurso é que vai proceder à compreensão das relações entre a formação discursiva e a formação ideológica na construção dos sentidos do discurso e, além disso, revelar as vozes dos sujeitos.

No Capítulo IV, analisamos os pontos de intersecções onde se encontram os veículos de comunicação alternativa e as inovações quanto à produção jornalística. Além do cenário de precarização estrutural, o trabalho desempenhado nesses arranjos é marcado pelos ideários da acumulação flexível (HARVEY, 1992), cuja tecnologia, ao mesmo tempo que inova a atividade laboral, também representa a densidade do trabalho.

Nesse capítulo, também apresentamos a base conceitual para delimitar a redação virtual como novo espaço social do trabalho jornalístico, a lógica de organização, as diferenças e semelhanças com a redação física.

Além dessa nova configuração do trabalho, demonstramos como as novas práticas realizadas nesses arranjos tensionam teorias do jornalismo, como o newsmaking e o gatekeeper, mudanças advindas principalmente do uso que esses veículos alternativos fazem das tecnologias de informação e comunicação.

É nesse capítulo também que evidenciamos como os arranjos se financiam e as tentativas de cooptação de forças que buscam neutralizar o conteúdo crítico produzido por eles através do financiamento das fundações.

Por fim, não fechamos a pesquisa em conclusões deterministas, mas apontamos considerações tanto sobre o tema da pesquisa quanto ao ofício do pesquisador em busca da 
produção de conhecimento para dialogar com questões concretas e necessárias da realidade social.

\section{A luta de ideia é mãe de todas as batalhas}

Em meio a tantas incertezas de um mundo e modo de produção em transição, em que a lógica da financeirização reduz Estados a meras agências reguladoras de interesses privados, ao vivenciar isso no Brasil percebemos que era necessário buscar ajuda para contribuir com essa realidade concreta.

Mais do que falas, discursos em praças públicas, era preciso tornar conscientes os movimentos que levaram o país a essa situação, realizar um balanço e apontar perspectivas em nosso campo de atuação da comunicação, passando necessariamente pela reflexão científica para que, com método, possamos travar essa luta em seu berço e, nesse embate, contribuir com propostas para uma sociedade mais justa e democrática.

À vista disso, a relação entre sujeito e o objeto tem como ponto de partida o caráter ético que permeia todo o processo da dissertação.

Como afirma Bianchi (2006, p. 136) “[...] e mais do que isso, se pode dizer que esse viés da ética precisa ir além, precisa, de alguma maneira, ter em sua constituição um senso de respeito ao ser humano, um sentimento de troca e não apenas de captação, que muitas vezes se traduz até mesmo em exploração".

Participamos ativamente da construção de iniciativas da mídia alternativa desde 2009, ano da I Conferência Nacional de Comunicação do Brasil. A nossa função não é reportar as atividades, mas conseguir com que todos esses arranjos possam dialogar e construir o sentido unitário da narrativa e, consequentemente, garantir espaços e ações unificadas em rede. Longe de ser um ofício prescrito, o nosso papel é, como nos denominam no seio do movimento, de "costurar redes".

Essa atribuição ficou muito mais complexa nos últimos tempos devido às condições históricas, políticas e sociais. Após a crise do capital deflagrada em 2007/2008, iniciou-se um movimento de disputa em torno dos recursos naturais, estatais, das relações de trabalho e da geopolítica, uma corrida que visa aumentar o lucro e cristalizar as diferenças sociais. 
Faz parte dessa disputa o rebaixamento da democracia, os embates sobre o papel do Estado e, consequentemente, a dissolução das fórmulas de economia políticas formuladas desde a última grande crise do capital de 1929, como o keynesianismo ${ }^{2}$, que previa minimamente uma política de Estado de bem-estar social.

Assim como também faz parte a disputa das subjetividades dos sujeitos para implantação de programas de austeridades, pois com o aumento do conservadorismo e as medidas austeras ficam mais fáceis de serem adotadas pelos Estados ou, ao menos, não são alvos de contestações das camadas populares.

Contribui para esse movimento no Brasil o posicionamento de forças que organizam o capitalismo por dentro do Estado como uma "gestão legalizada e autoritária", além do discurso dos últimos governos de Luiz Inácio Lula da Silva e Dilma Rousseff não terem feito a disputa ideológica no seio da sociedade. Ao contrário, assumiram a ideologia do capital, cujo centro do debate era acerca da técnica, da gestão, das competências, do estímulo ao crescimento da "classe média". Essa prática desses governos progressistas também serviu para desidratar o sentido da política e alimentar a antipolítica que hoje predomina no país.

Dessa forma, após o golpe no Estado Democrático de Direito em 2015 e, consequentemente, no pacto que resultou na Constituição Federal, de 1988, as forças democráticas e progressistas passaram a atuar em refluxo, refletindo na diminuição da militância e do engajamento. Assim, com menos pessoas e o aumento da agenda de defesa da democracia e dos direitos, ficamos embalados pelo "movimentismo e voluntarismo" que, de tantas atividades, fazem com que o processo consciente esteja em segundo plano.

Além da atuação no movimento pela democratização da comunicação, também conhecemos a realidade dos jornalistas nas redações das empresas comerciais do Estado de São Paulo por atuar na diretoria executiva do Sindicato dos Jornalistas Profissionais do Estado de São Paulo. A nossa principal atividade é acompanhar as mesas de negociações entre os sindicatos patronais de empresas de rádio e televisão, jornais e revistas, internet e assessoria de imprensa. Isso só é feito após o diálogo com os jornalistas nas redações. Fazemos visitas

\footnotetext{
${ }^{2}$ Conjunto das teorias e medidas propostas pelo economista britânico John Maynard Keynes e seus seguidores que defendiam, dentro dos parâmetros do mercado livre capitalista, a necessidade de uma forte intervenção econômica do Estado com o objetivo principal de garantir o pleno emprego e manter o controle da inflação.
} 
constantes in loco em redações de veículos como Folha de S. Paulo, Estado de S. Paulo, Globo, Record, SBT, Gazeta, entre outros.

A cada visita percebemos a redação dessas empresas diminuir, os jornalistas buscarem alternativas na profissão e muitos fora dela.

Essa realidade e incômodo intelectual foi o que fez perceber o valor da pesquisa para a sociedade e para o sujeito que encontra na epistemologia possibilidade de questionar, conhecer e abrir caminhos para transformar a realidade. 


\section{CAPÍTULO I}

Além da aparência: a construção do objeto de análise 
Nosso objeto de pesquisa são as relações de comunicação e trabalho do jornalista que atua nos veículos da mídia alternativa. As questões que conduzem o percurso teórico e metodológico são como se dão essas relações, em quais espaços e condições, bem como o papel das tecnologias de informação e comunicação (TICs) na organização do trabalho da produção jornalística, desde a seleção da pauta até a sua publicação.

Através da análise dos arranjos alternativos de mídia - Agência Pressenza, Jornalistas Livres, Opera Mundi e Outras Palavras - sediados no Ateliê do Bixiga, espaço compartilhado de trabalho, buscamos compreender essas relações, generalizar e abstrair fenômenos que possam dar suporte para pesquisas sobre o tema.

A primeira reflexão que fazemos no nível metodológico da pesquisa e na fase de construção do objeto é sobre a necessidade de adquirir vigilância epistemológica nas operações e relações que serão feitas durante todo o percurso da pesquisa. Uma abordagem teórica metodológica para um corte cirúrgico dos arranjos alternativos aos conglomerados de mídia no Brasil precisa apresentar os aspectos novos do cenário de comunicação transformados pelas TICs.

A crítica ao real transparente (LOPES, 2014) se faz necessária para a ruptura com o senso comum na busca de compreensão da lógica e das características dos objetos para ir além do que já é demonstrado sem aplicação de operações científicas e metodológicas. Pode parecer um movimento óbvio, mas sem o olhar científico não conseguimos nos distanciar das implicações que a realidade impõe ao objeto, dando à aparência o estado de essência. Vale a pena citar a afirmação de Karl Marx, contida no volume III de O capital. "Toda ciência seria supérflua se a aparência, a forma das coisas fosse totalmente idêntica à sua natureza." (2017, p. 551)

Essa vigilância epistemológica é ainda mais necessária quando o sujeito tem relação direta com o seu objeto. Isso porque pode haver a tendência de naturalização de fenômenos que são essenciais para alcançar o aprofundamento de determinadas explicações da pesquisa ou, ao contrário, de aumentar o impacto de questões que, individualmente, são problemáticas na visão do pesquisador.

Isso não significa que adotaremos a visão positivista de que quanto mais longe estiver o sujeito de seu objeto, mais conseguirá pesquisá-lo com profundidade. Essa tendência é 
realmente muito forte dentro do campo científico em que o sujeito é compreendido como neutro, restando a "relevância epistemológica" somente ao objeto do conhecimento.

Objeto e conhecimento são frutos de relações produzidas coletivamente, assim sendo, a função do pesquisador não é um trabalho individual. Portanto, é fundamental que conste como referencial teórico certo "estado da arte" sobre o assunto, referências às outras obras, em que são consideradas a produção da pesquisa - também compreendida como resultado de ação coletiva - por exemplo, com a contribuição de comunidade acadêmica em participação de eventos, grupos de pesquisas em que o conhecimento é discutido, socializado e referenciado dentro do campo científico da comunicação.

A relação sujeito-objeto também é refletida no conceito de reflexividade que, de acordo com Lopes (2010, p. 30), está presente desde Descartes, quando este consagrou o “cogito, ou seja, a capacidade da consciência de pensar-se a si mesma." Para o marxismo, essa posição foi considerada um avanço por deslocar Deus do centro das discussões.

De acordo com Giddens e Beck (1997, p. 16), é “[...] a premissa clássica de uma teoria da reflexão da modernidade [...]" que defende a modernização das sociedades e como impulsionar a capacidade de "[...] reflexão dos sujeitos sobre as condições sociais de sua existência e, assim modificá-las [...]” Do mesmo modo, Bianchi (2006, p. 135) trata os “[...] mecanismos utilizados na apropriação de uma informação, uma mensagem, sempre como sociais, histórica e culturalmente construídos.”

Outros autores, como Jean-Pierre Deslauriers e Michéle Kérisit (2008, p. 127), também discorrem sobre essa relação no processo de definição do objeto de pesquisa. De acordo com eles, “[...] haveria dois modos de conceber e de construir o objeto de pesquisa: para uns, é preciso conhecer para modificar; para outros, é preciso conhecer para conhecer melhor.” Para explicitar ainda mais, os autores se apoiam na dedução de Silverman:

Eu suspeito que as primeiras etapas da pesquisa se distanciam demasiado da lógica e da cronologia, como atestam as comunicações científicas. A maior parte da pesquisa está ligada ao acaso e a circunstâncias concernentes ao próprio pesquisador, no contexto econômico, social e político, no qual ele atua. (SILVERMAN, 1985, p. 4)

As mudanças nas relações de trabalho advindas pelo uso das tecnologias de informação e comunicação, somadas ao reflexo da crise do capital no jornalismo e a consequente diminuição das redações, exigem métodos que visam alcançar os aspectos estruturais do objeto. Estudar a mídia alternativa, as relações de comunicação e produção discursiva requer uma amálgama de técnicas para recortar as singularidades do fenômeno. 
Essas técnicas estão articuladas com categorias estruturantes, tendo como recurso teórico metodológico o materialismo histórico dialético, o binômio comunicação e trabalho (FIGARO, 2008) e a ergologia (SCHWARTZ; DURRIVE, 2008).

Essa é a ideia fundante da ligação dialética entre comunicação e trabalho. Sem trabalho não é possível haver comunicação; sem comunicação não há maneiras de realizar a atividade de trabalho. Isso desde o desenvolvimento da consciência humana até os dias atuais e, possivelmente - modalizamos para evitar uma visão determinista da história -, será no futuro. Junto com o materialismo histórico dialético ${ }^{3}$, usaremos a ergologia (SCHWARTZ, 2008) como abordagem teórica metodológica para apreender a comunicação no trabalho, tema do próximo ponto.

\section{O ponto de vista do trabalho}

O mundo do trabalho é denominado assim porque é complexo, com muitas contradições, decisivo para entender as relações sociais - materiais e históricas - e apreender a realidade além de sua aparência, na essência, na radicalidade do mundo concreto.

Karl Marx, em seu livro A ideologia alemã (1985), sustenta que a relação do homem com a natureza para garantir a produção e a reprodução de suas condições existenciais é a base do materialismo. "Uma forma específica de apropriação da natureza determina as formas de organização social e a consciência.” (MARX apud SADER, 2010. p. 15)

\footnotetext{
${ }^{3}$ A relação entre pensamento e o ser marcou as principais discussões filosóficas em toda a história. Matéria e consciência, natureza e sociedade, homem e natureza são temas que caracterizam a filosofia desde os seus primeiros pensadores. Mesmo se baseando na vanguarda do pensamento filosófico, o marxismo criticou desde o início os idealistas e os pré-materialistas como Feuerbach que, segundo Marx e Engels (1984), "[...] quer objetos sensíveis, realmente distintos daqueles do pensamento; mas ele não concebe a própria atividade humana como atividade objetiva." A crítica geral pode ser observada na seguinte afirmação de Marx em A ideologia alemã: "Toda concepção histórica, até o momento, ou tem omitido completamente esta base real da história, ou a tem considerado como algo secundário, sem qualquer conexão com o curso da história. Isto faz com que a história deva sempre ser escrita de acordo com um critério fora dela. A produção da vida real aparece como algo separado da vida comum, como algo extra e supraterrestre. Com isto, a relação dos homens com a natureza é excluída da história, o que engendra a oposição entre natureza e história.” (MARX;ENGELS, 1984, p. 57)A partir da ideia de que a consciência é fruto da prática social, ou seja, "[...] que os homens, ao desenvolverem sua produção material e seu intercâmbio material, transformam também, com esta atividade a sua realidade, seu pensar e os seus produtos de pensar [...]" (MARX, 1984), o ponto de partida para o movimento dialético e as categorias que refletem a relação ser e natureza pode ser considerado como passo inicial para compreensão da dialética materialista. Engels, em Dialética da natureza (1952), afirma que "[...] é precisamente a transformação da natureza pelo homem, e não a própria natureza como tal que é o fundamento mais essencial e mais direto do pensamento humano, e a inteligência do homem aumentou na medida em que ele aprendeu a transformar a natureza."
} 
Desde suas primeiras obras, Marx e Engels identificam um papel para a categoria trabalho, porém inicialmente era apenas uma forma geral de luta do homem contra a natureza, como base de todas as sociedades humanas. O labor esteve, desde o início, ligado à alienação, provocando a questão da forma como essa degeneração da atividade humana foi possível. Mas desde o começo, o trabalho era analisado na perspectiva da sua abolição, do processo de desalienação, revelando como se tratava já de uma análise ao mesmo tempo negativa e positiva. (SADER, 2010, p. 14)

O autor de $\mathbf{O}$ capital coloca o trabalho como pressuposto de toda existência humana, como "primeiro ato histórico" para suprir as necessidades de se alimentar, morar, vestir etc. Também é no trabalho, na troca com outros indivíduos que se dá a existência da consciência e da linguagem.

A linguagem é também a consciência real, aponta a teoria marxiana. Nascem juntas, siamesas, pela necessidade de o homem viver com o outro, em troca, estimulando e articulada com o trabalho do cérebro humano.

Engels, em seu clássico texto Dialética da natureza (1979), defende que a consciência é, entre outras habilidades, a capacidade de abstração e de discernimento que contribuiu com o desenvolvimento do trabalho, ação do homem sobre a natureza e sobre a "palavra".

Esse desenvolvimento dos sentidos, da linguagem, da consciência fez com que o homem evoluísse, se tornasse capaz de realizar operações complexas e pudesse viver em grupo. É justamente o trabalho - e a fabricação de instrumentos -, a linguagem e a consciência que distinguem o homem de outros animais.

A atividade essencialmente humana do trabalho é social por este não poder existir sem a cooperação entre os sujeitos. Conseguimos imaginar divisão de trabalho sem comunicação entre os indivíduos? Para Marx apud Leontiev, em O desenvolvimento do psiquismo, isso não é possível:

$\mathrm{Na}$ produção os homens não agem apenas sobre a natureza. Eles só produzem colaborando de uma determinada maneira e trocando entre si as suas atividades. Para produzir, entram em ligações e relações determinadas uns com os outros e não é senão nos limites dessas relações e dessas ligações sociais que se estabelece a sua ação sobre a natureza, a produção (MARX apud LEONTIEV, 2004, p. 81).

Ao se apoiar nesse raciocínio marxista, Leontiev afirma que a “[...] linguagem não desempenha apenas o papel de meio de comunicação entre os homens, ela é também uma forma da consciência e do pensamento humano.” (ibidem p. 82) 
Por consciência, entendemos o sentido que orienta a ação humana, reflexo da realidade concreta destacada das relações que existem entre a própria realidade e o sujeito.

A linguagem age na produção desse reflexo da realidade e é ao mesmo tempo produto forjado na prática social, segundo o polonês Adam Schaff (1975, p. 239):

Ao falar da ação da prática humana sobre conhecimento, fizemos a reserva de que se trata da prática acumulada, tanto na ontogênese como na filogênese do homem; de que se trata, portanto, não só (e nem sequer principalmente) das transformações que o indivíduo opera na realidade e que compõem a sua experiência social, mas antes de tudo, da prática social cujos produtos são referenciados de modos diversos aos membros da sociedade.

Se a linguagem atua na formação da realidade, ela também age na percepção humana e define até certo grau a nossa visão de mundo. Essa realidade é formada predominantemente no trabalho, na atividade em que aqueles que não têm os meios de produção passam na jornada cada vez mais prolongada de, no mínimo, oito horas por dia.

A abordagem ergológica que "[...] conforma o projeto de melhor conhecer e, sobretudo, de melhor intervir sobre as situações de trabalho, para transformá-las [...]" (SCHWARTZ; DURRIVE, 2008) mobiliza o trabalho enquanto categoria central na relação micro e macrossocial da atividade.

Influenciado pelas ideias de Georges Canguilhem, Yves Schwartz debruça-se sobre a atividade micro de trabalho para compreender como se dá a relação entre sujeito e o trabalho, buscando identificar o que o trabalhador apreende para as suas experiências e como ele contribui com a sociedade.

A partir dessa associação, Figaro vai além da ergologia e posiciona o sujeito como ser "histórico concreto em meio a embates sociais". A perspectiva sobre o papel da ergologia auxilia a identificação das contradições entre capital e trabalho.

O sujeito, portanto, é o indivíduo/social, ser histórico concreto, que se posiciona em relação aos embates das lutas entre as classes sociais e sofre esses embates, com as injunções do trabalho explorado e do poder do capital. É este o sujeito da comunicação, o ser social que diz "eu" e identifica ou escamoteia o "outro" da comunicação. Nesse sentido, as relações de comunicação revelam os conflitos e as contradições sociais. A comunicação não tem por si mesmo o papel de criar consenso. Estudar a comunicação no mundo do trabalho, na perspectiva do binômio comunicação e trabalho, é identificar os sujeitos sociais e as contradições, conflitos (do trabalho) na sociedade contemporânea; é entender as relações de comunicação entre os sujeitos sociais como totalidade que revela a sociedade. (FIGARO, 2015, p. 117) 
Nessa perspectiva, a atividade de trabalho, de acordo tanto com Marx e Engels, como no sentido ergológico, quanto a partir do binômio comunicação e trabalho, é considerada uma atividade humana, muito além da simples execução ou um processo de alienação.

Vale fazermos duas ressalvas: a primeira é a de que se considerarmos o trabalho como emprego deixaremos passar, assim como água entre os dedos, a complexidade do trabalho como expressão específica de um movimento mais geral que é a atividade humana. A segunda é sobre o conceito de alienação que, muitas vezes, encontramos na literatura ou no uso comum de maneira deturpada do conceito originário.

A alienação derivada do trabalho é aquela que aliena o sujeito do processo por inteiro sobre a sua produção. Diz respeito ao estranhamento de si no trabalho; à impossibilidade de decidir e de se apropriar dos frutos do trabalho. É natural, portanto, que os sujeitos busquem a todo o momento formas de conduzir o próprio trabalho. Esse embate revela o esforço pelo reconhecimento e o domínio sobre a condição de sujeito humano.

Para a ergologia, durante todo o processo de trabalho, o indivíduo depara com debates, normas, necessidade de escolhas de como realizar as suas funções. Esse conjunto de embates gera e encontra valores na realidade concreta. É uma batalha permanente a qual faz com que o sujeito queira sair da norma. É o que Schwartz e Durrive denomina de "renormalização" (2018). É o esforço do corpo si (grifo nosso) para fazer a gestão de si no trabalho e colocar limites na gestão do outro sobre si.

\footnotetext{
Mas a ideia de atividade é sempre um 'fazer de outra forma' um 'trabalhar de outra forma'. Não é uma palavra de ordem projetada no futuro: está dentro da realidade, é uma espécie de obrigação mesma de qualquer situação de atividade de trabalho humano já incluir uma dimensão de transformação. (SCHWARTZ; DURRIVE, 2008, p. 35)
}

O ponto de vista do trabalho para a ergologia é compreendido como esse processo que se dá a partir do lugar em que se encontra o trabalhador. O conhecimento de apoio para as decisões no trabalho está em todo corpo do sujeito e em sua experiência. Schwartz prefere utilizar o conceito de "corpo-si" por julgar que o conceito de sujeito está muito desgastado.

Ao conceito de "corpo-si" agrega a dimensão física e a relação do homem com o meio durante toda história cultural da humanidade. Inseparável da evolução da vida e diferentemente do meio vivo, ele é "[...] atravessado por valores, histórias, normas antagônicas [...]" (SCHWARTZ; DURRIVE, 2008) Isso significa que a “[...] atividade de 
trabalho é o momento maior de expressão da capacidade do corpo-si. É na atividade que o corpo-si completa-se.” (FIGARO, 2008)

O conceito evidencia diferentes dimensões e nos traz tantas reflexões que é preciso explicitar como o próprio autor define:

O corpo-si é a história, a história da vida, da espécie, da pessoa, é a história dos reencontros sempre renovados entre um ser em equilíbrio mais ou menos instável e uma vida social com seus valores, suas solicitações, seus dramas. O corpo-si é história, história como memória sedimentada, organizada nas miríades de circuitos da pessoa; mas também história como matriz, energia produtora do inédito: na medida em que a finalidade renormalizadora é às vezes imposta ao ser - o meio 'infiel'; como 'reencontro' reclama que se escolhendo tal ou qual maneira de tratá-lo e, ao mesmo tempo, requerido como exigência de vida, como apelo nele de saúde, utilizando-o sem repouso para tentar transformar o que é objetivamente para ele meio (ambiente) (umgebung) no que poderia torná-lo o seu meio (ambiente) (Umwelt). (SCHWARTZ; DURRIVE, 2008, p. 120)

Embora o autor não aproxime a teoria marxiana da ergologia, vamos relacionar a materialidade que adquire o trabalho concreto na transformação da vida humana, da natureza e da sociedade ao ponto de vista ergológico. Também podemos salientar que essa aproximação se dá nos termos da materialidade objetiva em que o "corpo si" é compreendido, ou seja, uma miríade de atividades que colocam o ser que trabalha em perspectiva no centro das transformações sociais.

Apontamos dessa forma, pois a questão não resolvida entre marxismo e ergologia é que esta última limita-se a compreender o micro do trabalho em função das questões macrossociais sem, no entanto, fazer o retorno de como as questões mais gerais da economia e do poder são normativos e prescritivos (controladores) das situações de trabalho; outra questão pendente para a ergologia é a de que ela não trata a luta de classes. Centra-se no micro do trabalho por meio da compreensão das "entidades" (relativamente pertinentes) que ali se criam para a gestão do si e do outro no trabalho, desvinculando essas "entidades" do embate entre as classes.

Mesmo assim, a ergologia potencializa a análise das situações concretas de trabalho. Desse modo, essa abordagem nos é útil na pesquisa, bem como permite perceber o ineditismo do trabalho e seu potencial transformador, forma concreta e objetiva que se debate com a apropriação privada dos valores do trabalho.

A partir do ponto de vista do trabalho e do trabalhador, a ergologia considera o trabalho real sempre inédito a cada ato e em constante renormatização. Essa afirmação aponta 
o desafio sobre qual método podemos utilizar para apreender as relações de comunicação, os valores acionados no e pelo trabalho (grifo nosso) e como entendermos essa atividade além da aparência das normas, manuais e prescrições.

Schwartz elaborou o "dispositivo dinâmico em três polos", uma abordagem teóricoprática que coloca em movimento dois tipos de conhecimento utilizados na atividade de trabalho. $\mathrm{O}$ dispositivo revela o tensionamento entre o conhecimento científico e o ampliado com o conhecimento engajado na história concreta do trabalho. O terceiro polo é a ergologia, que movimenta os dois polos para que o eixo se renove. Figaro explana sobre a aplicação do dispositivo:

O dispositivo dinâmico em três polos permite pela força do questionamento, confrontar a norma e a experiência pela atividade de trabalho, revelando os conflitos e as contradições sociais e, principalmente, a potencialidade de transformação do sujeito (corpo-si). Essa proposta permite ainda articular a dialética do micro ao macrossocial. Dá condições de se compreender como as transformações no mundo do trabalho se articulam com os valores e as normas sociais e como a realidade do mundo do trabalho transborda para outras instituições e grupos sociais. (FÍGARO, 2008, p. 122)

Ao utilizarmos o dispositivo para análise dos veículos de comunicação da mídia alternativa, vamos perceber a ligação entre a realização inédita do trabalho e a concepção de mundo dos jornalistas, ao mesmo tempo em que a própria atividade nos revelará conflitos além dos manuais e das orientações para a redação, tais como é o tratamento com a fonte e entre os trabalhadores de outros arranjos, os quais têm o mesmo objetivo e visão da comunicação coincidentes, por exemplo.

Desse modo, a atividade de trabalho será utilizada como unidade para compreender os sentidos produzidos pelo próprio trabalho e como esse sentido retorna para a sociedade.

\section{Uma triangulação da linguagem sobre/como/no trabalho}

Ao dar continuidade às questões teórico-metodológicas que articulam comunicação e trabalho, recorremos ao conceito de atividade linguageira materializada nas diferentes situações de comunicação. Abdallah Nouroudine (2002) usa o termo genérico de "práticas linguageiras", que abrange conceitualmente a atividade da linguagem como linguagem sobre o trabalho, linguagem como trabalho e linguagem no trabalho (grifo nosso). Tal distinção dessas atividades se faz necessária para identificação das relações de comunicação enunciadas na ligação entre linguagem e trabalho e, consequentemente, captar o uso do discurso no 
mundo do trabalho. O autor reflete que "[...] ao tratar essa questão, a reflexão recairá, necessariamente, em um debate sobre as condições de produção de saber, a partir de prospecções acerca das condições de produção simplesmente.” (idem, p. 16)

A linguagem como trabalho é realizada pelo sujeito para orientar o próprio trabalho e acontece no processo coletivo de produção que exige cooperação e diálogo, mesmo sendo econômico, porque faz parte a gestão do tempo no trabalho. A orientação do trabalho e a cooperação somente são oportunos se permitirem conciliar a saúde dos atores do trabalho e a eficácia do produto produzido.

[...] a linguagem como atividade integra aspectos estratégicos definíveis como fala para si e fala ao outro, centrada essencialmente aqui nos desafios da realização do trabalho e da existência da identidade pessoal dentro e pelo grupo, sobretudo através do tempo. (NOUROUDINE, 2002. p.19)

A própria linguagem é parte do trabalho, legitimada por ele, em que a complexidade de ambas categorias se confunde e entrelaça. "A linguagem como trabalho não é somente uma dimensão, dentre outras, do trabalho, mas ela própria se reveste de uma série de dimensões." (idem, p. 20) Com essa lógica todos os gestos, falas, sinais que são feitos com o objetivo de realizar a ação, fazem parte do trabalho.

Esse olhar metodológico é importante para apreender os aspectos do trabalho como um todo e não somente a prescrição formal da atividade. Omitir essas características é atingir apenas a superficialidade de qualquer análise das relações de comunicação no trabalho.

Da mesma forma não podemos anular a linguagem no trabalho (grifo nosso), pois como atividade contém elementos complexos como as formas de relacionamento dentro do coletivo, as interações, as relações feitas pela linguagem.

\footnotetext{
Enquanto a "linguagem como trabalho" é expressão pelo ator e/ou coletivo dentro da atividade, em tempo e lugar reais, a linguagem no trabalho (grifo nosso) seria, antes, uma das realidades constitutivas da situação do trabalho global na qual se desenrola a atividade. É nesse ponto que os dois aspectos da linguagem são, simultaneamente, distintos e ligados. (NOUROUDINE, 2002, p. 22)
}

Os limites entre as duas situações da linguagem no e como trabalho são híbridos e representam também múltiplas dimensões para análise no local onde se manifestam as relações de comunicação: falas, emoções e evidenciando, inclusive, os aspectos históricos e sociais do indivíduo e da realidade do trabalho. Por exemplo, um trabalhador pode, na mesma situação, utilizar a linguagem no trabalho, enquanto outro estará utilizando a linguagem como trabalho. 
Conversar sobre a vida pessoal de um ou de outro, sobre problemas da política atual, fazer observações sobre as ferramentas empregadas no setor vizinho ou na empresa concorrente, comentar o jogo de futebol da véspera, etc. - todos esses assuntos fazem parte da linguagem no trabalho, uma vez que favorecem trocar na situação de trabalho. A interação entre os elementos materiais e simbólicos da situação de trabalho a partir de um centro de referência, que é o sujeito individual/coletivo, atribui à linguagem um papel privilegiado no processo de representação e de discriminação dos fatores pertinentes a um momento determinado para realizar o trabalho com eficiência e segurança. (NOUROUDINE, 2002, p. 24)

Não há uma linha divisória entre a linguagem como e no trabalho, mesmo quando se busca alcançar a linguagem sobre o trabalho (grifos nosso), o ponto que fecha o triângulo dos níveis da produção discursiva da linguagem no mundo do trabalho.

Linguagem sobre o trabalho são as falas do trabalho produzidas pelos próprios protagonistas da atividade. É expressa na convocação do trabalho através de comentário, avaliação, projeção.

Para perceber a linguagem sobre trabalho é importante a averiguação "[...] acerca de quem fala, de onde o ator fala, quando ele fala para compreender onde se situa o campo de validade e de pertinência da linguagem sobre trabalho." (NOUROUDINE, 2002, loc. cit.)

Os desafios de análise dessa triangulação são relevantes, principalmente devido à dificuldade de identificar quando a linguagem é como, no ou sobre o trabalho (grifos nosso) ou mesmo quando se dá o entrelaçamento dos níveis.

Analisar uma situação de trabalho através das práticas linguageiras no cenário atual, no qual as redes e grupos de conversa organizam o trabalho, em nosso caso, significa participar por dentro dos aplicativos e sites de redes sociais. Os jornalistas dialogam mais nesses espaços do que presencialmente. $\mathrm{O}$ debate sobre o trabalho fica concentrado nessas ferramentas e pode ser comentado, compartilhado, registrado todo tempo com todos que fazem parte da redação, bastando a pessoa estar on-line naquele momento e querer opinar sobre algum tema.

Essa forma de pesquisa de campo e observação é desafiadora. Em alguns casos, o volume é incontável e exige novas técnicas para análise, como a mineração de dados no grupo. Em redações menores e com espaço físico e sem o espaço virtual de trabalho - o qual falaremos mais nos capítulos III e IV - há a dificuldade de entrar nas conversas bilaterais ou grupos paralelos no espaço virtual. A conversa que antes acontecia no "cafezinho", para falar algo reservado sobre o trabalho, acontece agora no celular, na conversa entre duas pessoas ou em grupos que se formam por afinidades ou acontecimentos nas redes. 
Como já afirmamos, a própria linguagem tem suas dimensões e sua complexidade e se dá em um processo entrelaçado às complexidades do mundo do trabalho.

Isso reflete na necessidade de o pesquisador ter vigilância epistemológica durante todo processo de investigação em relação ao sujeito entrevistador e ao entrevistado, em fazer uma espécie de diário de entrevistas, em deixar a fala do entrevistado aparecer e não se precipitar ou adiantar dentro da sua própria perspectiva, no cuidado quanto à elaboração do questionário, entre outras ações conscientes do sujeito da pesquisa, que podem garantir que o fenômeno seja estudado de maneira complexa, global e estruturante.

\section{O objeto de análise}

O nosso objeto de análise é o Ateliê do Bixiga, um espaço de trabalho compartilhado entre quatro arranjos alternativos de comunicação que atuam nesse ambiente.

O Ateliê do Bixiga ganhou esse nome recentemente (setembro de 2018) em um processo para tornar o espaço "mais profissional". Faz parte das mudanças programadas a criação de uma zeladoria que cuida das contas, reformas, agenda do espaço, limpeza, condomínio e todos os espaços comuns da casa. No começo era chamado de Ateliê do Gervásio, sobrenome do proprietário do espaço. Antes de ser voltado a grupos de trabalho, era uma casa de eventos e festas. 


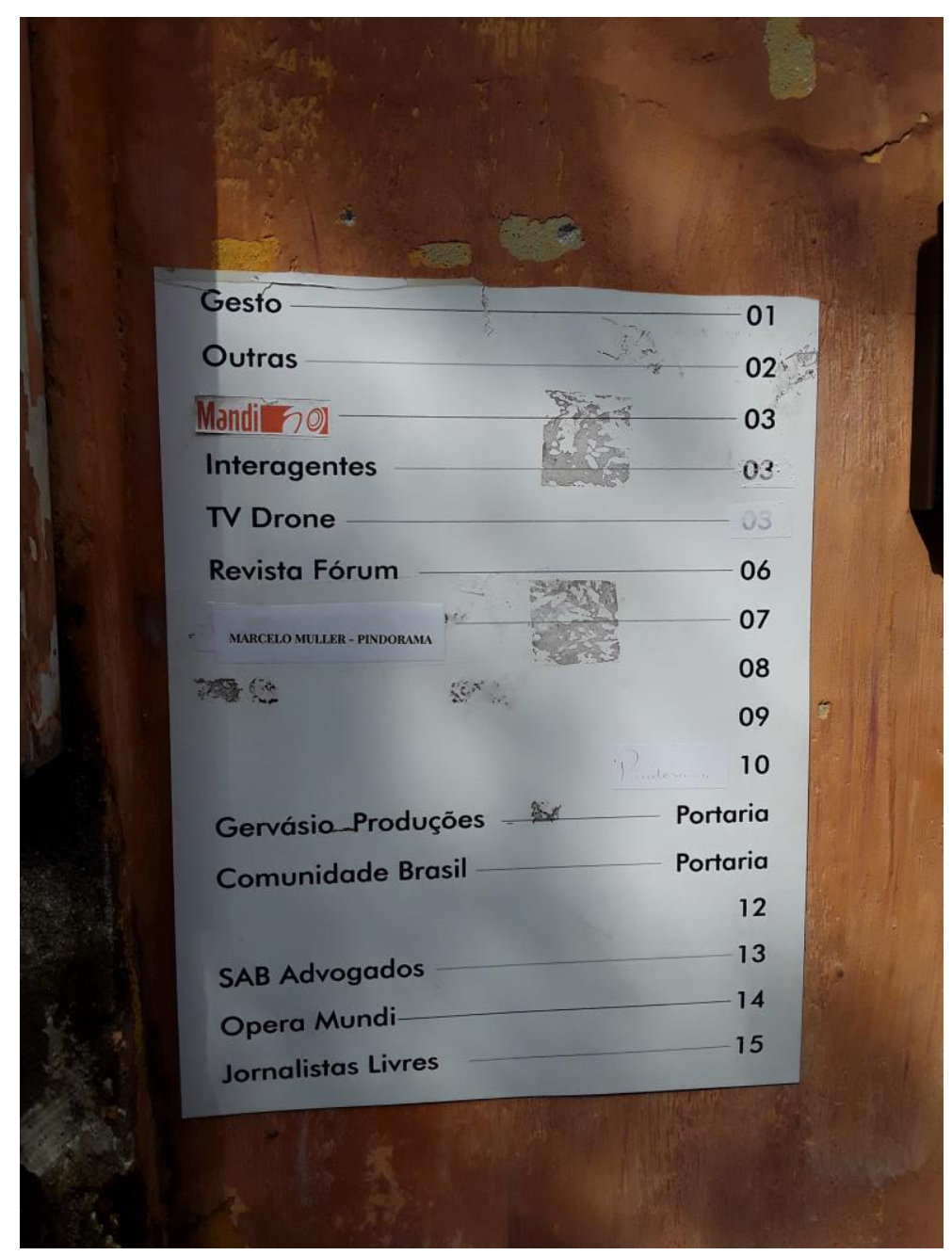

Figura 1 - Lista do interfone do Ateliê do Bixiga no início da pesquisa. Fonte: Autora

Já se encontraram no espaço veículos de comunicação, organizações sociais e empresas. São elas: Govinda Restaurante, Pindorama (empresa de manutenção de ar condicionado), Sempre Viva (produtora de eventos), Mandi (produtora de eventos), Saccomani Albuquerque Biral (SAB Advogados, que também atua no Advogados Ativistas ${ }^{4}$ ), Autonomia Literária (editora de livros), Actantes (coletivo hacker) e os arranjos da área de comunicação que compõem o nosso corpus:

- Jornalistas Livres: apresentam-se como realizadores de um jornalismo democrático, plural, em rede, pela diversidade e defesa implacável dos direitos humanos. Foi criado no dia 12 de março de 2015 em meio às manifestações pelo impeachment da ex-presidente Dilma Rousseff, devido à "necessidade urgente de enfrentar a escalada da narrativa de ódio, antidemocrática e de permanente desrespeito aos direitos humanos e sociais" ${ }^{\text {, em grande }}$

\footnotetext{
${ }^{4}$ Grupo de advogados que defendem oferecem instrução jurídica para manifestantes.

${ }^{5}$ Ver mais em https://jornalistaslivres.org/tag/manifesto
} 
parte apoiada pela mídia tradicional. Os Jornalistas Livres - conhecidos como JLs - são oriundos da campanha de cobertura jornalística "Conta D’Água"6, que reuniu diferentes coletivos da mídia alternativa para falar sobre a crise hídrica em São Paulo.

- Outras Palavras: primeiro arranjo a fazer parte do Ateliê do Bixiga e que convidou outros coletivos e veículos para compartilhar o espaço. Foi fundado em 2009 e teve influência dos coletivos de mídia livre articulados em torno do Fórum Social Mundial e do programa Pontos de Cultura, política governamental implementada nos governos de Luiz Inácio Lula da Silva e Dilma Rousseff. Ganhou o Prêmio Ponto de Mídia Livre. Hoje conta com 200 colaboradores e aborda o "exame crítico da globalização, as novas culturas políticas da autonomia e os movimentos de ocupação das redes e das ruas". ${ }^{7}$

- Opera Mundi: lançado em $2008^{8}$, o site propõe a fazer uma ampla cobertura da política internacional com a produção de reportagens e "[...] incursões na área da cultura, comportamento e debate ideológico." (CERAVOLO; TERRA, 2014, p. 7) Assume o posicionamento de esquerda e afirma que "nunca abriu mão de princípios e fundamentos do fazer jornalístico informativo" com a influência da imprensa independente e alternativa. "É impossível ler Opera Mundi e não perceber a sua filiação a projetos como a 'Revista Movimento', 'Versus', 'Opinião' e até mesmo 'Pasquim'. Também há evidentes com projetos nos anos 1980 e 1990" afirmam os organizadores do livro O Mundo em Movimento, Haroldo Ceravolo e Marina Terra (ibidem, ibidem).

- Agência Pressenza: é a representação da agência de notícias internacional que tem sede em Quito e foi criada em Milão, Itália, em 2009. Com uma concepção pacifista e humanista, "participa de uma ampla rede de novos meios que conseguem difusão mundial de suas propostas locais ao mesmo tempo em que nutrem suas informações com o material que provê a agência" ". É formada por trabalhadores voluntários que atuam como colunistas, repórteres, fotógrafos, gráficos, videomakers, tradutores em 24 países. Em São Paulo, a equipe também faz parte da agência de conteúdo $4 \mathrm{~V}$, que elabora vídeos como prestação de serviços.

Para aprofundar a caracterização e análise faremos o detalhamento de cada um no terceiro capítulo dessa dissertação.

\footnotetext{
${ }^{6}$ Articulação que agregou diferentes veículos da mídia alternativa para cobertura da crise hídrica de São Paulo de 2014.

${ }^{7}$ Ver mais em outraspalavras.net

${ }^{8}$ Ver mais em operamundi.com.br

${ }^{9}$ Ver mais em https://www.pressenza.com/pt-pt/sobre-nos/
} 


\section{Conselheiro Ramalho, 945 - Ateliê do Bixiga}

Fruto de uma experiência de política pública de cultura, o Ateliê do Bixiga abriga diferentes perfis de arranjos, de produtora de eventos a escritório de advocacia. Porém, no início agregava arranjos alternativos de comunicação. Por isso, decidimos ter esse recorte empírico.

Analisar o espaço compartilhado de trabalho de diferentes arranjos significa entender o potencial de saídas coletivas para o fortalecimento de iniciativas contra-hegemônicas, mas também quais são as particularidades e semelhanças de cada um deles.

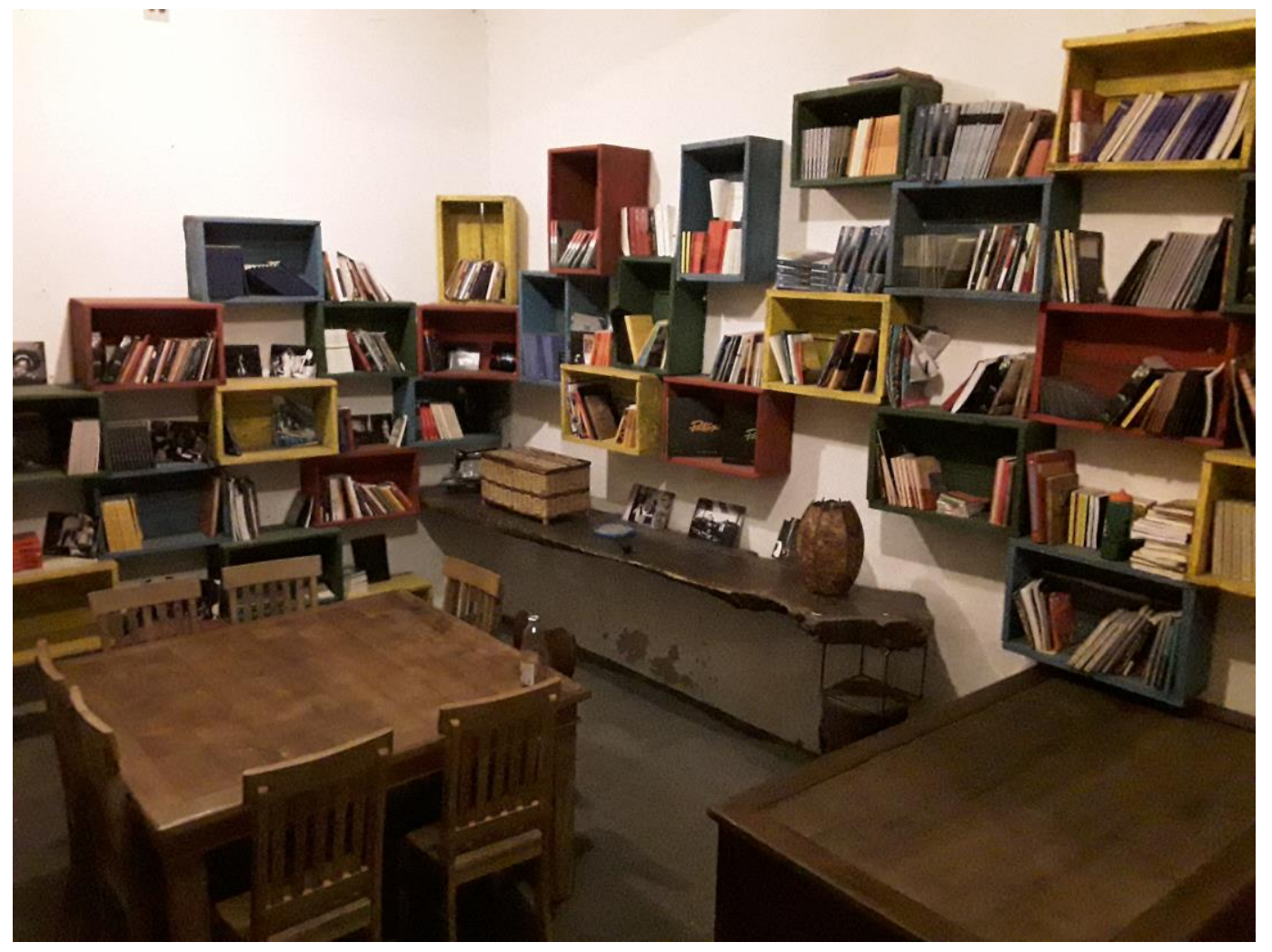

Figura 2 - Biblioteca do Ateliê. Fonte: Autora (2018)

O programa Pontos de Cultura foi criado na gestão de Luiz Inácio Lula da Silva para financiar e apoiar organizações não governamentais ou entidades governamentais já existentes como medida de apoio sociocultural em comunidades como a rádio comunitária de Heliópolis, os Caiçaras de Cananeia, o Museu da Maré, entre outros:

Ponto de Cultura é um conceito. Um conceito de autonomia e protagonismo sociocultural. Na dimensão da arte vai além da louvação de uma arte ingênua e simples, como se ao povo coubesse apenas o lugar do artesanato e do não elaborado 
nos cânones do bom gosto. Pelo contrário, busca sofisticar o 'olhar', apurar os ouvidos, ouvir o silêncio e ver o que não é mostrado. (TURINO, 2011, ${ }^{10}$ p. 6)

Para "desesconder o Brasil" e "acreditar no povo", o financiamento não previa uma forma única para ser gasto o recurso. A única condição era a aquisição de, pelo menos, um pequeno equipamento para edição de áudio e imagem, computadores funcionando como ilha de edição em software livre, filmadora digital, equipamento de som para gravação de CD e conexão por internet em banda larga. O objetivo era "[...] potenciar o que já existe, firmar pactos e parcerias com 'os de baixo'.” (idem, p. 9)

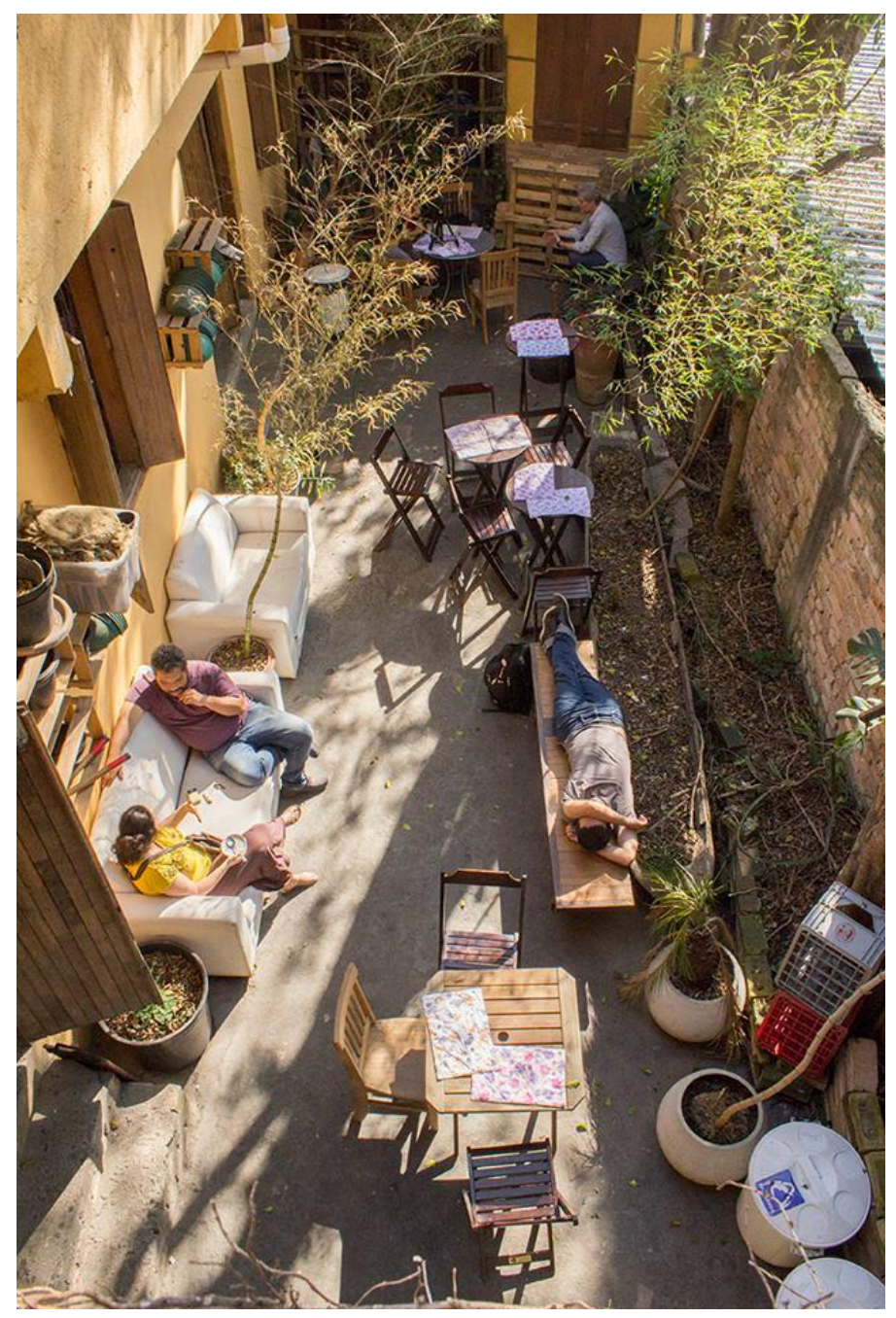

Figura 3 - Os espaços e horários comuns, como o almoço são os momentos de troca - Fonte: Reprodução Facebook (2018)

Dessa maneira, estavam dadas as condições para que os coletivos pudessem produzir a sua própria comunicação. A utilização desse investimento e maquinário foi responsável pelo

\footnotetext{
${ }^{10}$ Não consta ISBN na publicação utilizada.
} 
surgimento e fortalecimento de arranjos alternativos de comunicação, como o Fora do Eixo/Mídia Ninja e o site Outras Palavras, componente de nossa pesquisa.

A etapa seguinte do programa foi a proposição do Ministério da Cultura, na gestão da presidente Dilma Rousseff, de um edital específico para fomentar mídia livre.

A possibilidade de formular uma proposta de política pública a partir da análise do espaço compartilhado de trabalho, mediante a experiência dos Pontos de Cultura, os chamados desertos de notícias e a posse de imóveis por parte do Estado, como apoio de espaços comuns para coletivos jornalísticos para viabilizar a pluralidade de produtores de informação na sociedade, foi fator determinante para definir o recorte de nossa pesquisa.

No Ateliê do Bixiga já trabalharam, além dos quatro arranjos que fazem parte desta dissertação, a revista Fórum, Ponte Jornalismo e o De Olho nos Ruralistas (este continua no espaço). O primeiro a se instalar foi o Outras Palavras, que liderou a constituição de um lugar comum para esses coletivos/veículos de comunicação.

Diferentemente de um coworking ${ }^{11}$, o espaço não tem uma estrutura centralizada como gerente ou administrador, mas ao mesmo tempo as pessoas pagam aluguel do espaço para usar as salas de trabalho. $\mathrm{O}$ zelador, Márcio $\mathrm{Mendes}^{12}$, pontua que além de ser apenas uma casa alugada, as entidades que dividem o local criaram uma associação para realização de projetos sociais para a comunidade e que há projetos pontuais que articulam as empresas e /ou coletivos, "[...] lutas em comum e interesses em auxiliar e ampliar a força da luta".

Para organizar a associação, cada condômino está representado na direção, incluindo a cozinheira que tem um restaurante vegetariano no espaço, os advogados que têm uma empresa no local e o responsável pela editora. As reuniões são o ambiente para debater tanto os projetos quanto as questões de manutenção.

A presidente da associação, Patrícia Mourão, defende que não é apenas um local de trabalho que aluga sala, mas um local de convivência em que há socialização e troca do trabalho:

Se preciso de uma agência pra fazer um vídeo, então a gente já tem na casa, eu preciso de advogado, tem na casa também, a gente se ajuda, os projetos eles se completam, então, é mais que um local de trabalho onde você tem o horário de entrada e o horário de saída e ponto final. E tem também esse modelo que é mais

\footnotetext{
${ }^{11}$ Compartilhamento de local e recursos de trabalho de escritório que serve de alternativa para a modalidade home-office.

12 Todos os nomes dos entrevistados presentes nessa pesquisa foram alterados a pedido dos participantes.
} 
corporativo, que não me agrada inclusive, mas são empresas que querem ser modernas, descoladas e aí vão para um coworking e aí é todo mundo usa terno gravata, sapatinho bem lustrado e tem aquela formalidade toda assim, que é minha mesa, meu espaço mas não conversar com a pessoa do lado, não tem essa interatividade, já conheci alguns assim (PATRÍCIA MOURÃO, 2018).

Podemos usar o conceito de Schwartz (2008) de "entidades coletivas relativamente pertinentes" para compreender a circulação da comunicação no Ateliê do Bixiga, através do compartilhamento de valores e o fortalecimento dos laços entre as pessoas que transborda além do trabalho. Para ficar mais claro, Schwartz explica que:

[...]cada vez que há um novo princípio técnico a empregar, criam-se entidades coletivas para os operar que jamais recobrem exatamente aquelas que tínhamos previsto de maneira dedutiva. É "relativamente pertinente" porque não está dentro de um organograma. (2008, p. 89)

Não raro, o grupo de advogados da Casa prepara os contratos de aluguéis, participa das matérias como fonte, oferece suporte para casos - como de apreensão de máquinas em manifestações e defendem manifestantes, como aconteceu em 2013, no período dos atos contra o aumento da passagem em que foram mais de 2 mil boletins de ocorrências e 5 mil atendimentos.

[...] gente não tem esse padrão, a gente tem um público que frequenta aqui. A gente sabe quem vem aqui, quem vai ao Ópera, na Matrioska, o público é diversificado e as vocações também são diversificadas, a gente não engessou colocando só uma regra, é só comunicação, é só direito. Não. A gente juntou vários seguimentos e acho que isso que dá uma coisa diferente pra casa, aqui você encontra de tudo qualquer um de qualquer ramo consegue vim e trabalhar aqui. (LUÍS GOMES, 2018)

A escolha da casa como recorte do objeto tornou a nossa pesquisa mais relevante por ver os arranjos como parte do contexto de outras entidades e empresas, bem como a influência desse fator nas relações de comunicação e trabalho.

Agora, vamos explicitar o conjunto de técnicas metodológicas utilizadas no processo de análise.

\section{Combinação de técnicas utilizadas na pesquisa}

Por se tratar de um estudo de casos múltiplos, com observação participante, o conjunto de dados é volumoso e requer uma vigilância prática no planejamento da pesquisa e organização do conteúdo. A relação entre entrevistador e entrevistado vai muito além da observação, "[...] acabam se identificando, sobretudo quando os objetos são sujeitos sociais também.” (DEMO, 1984, p. 115) 
A utilização de estudo de caso múltiplos tem como proposta ofertar características para expandir o conhecimento, alargar a compreensão teórica acerca dos elementos estruturantes, tornando-os mais evidentes para continuidade e confirmações futuras.

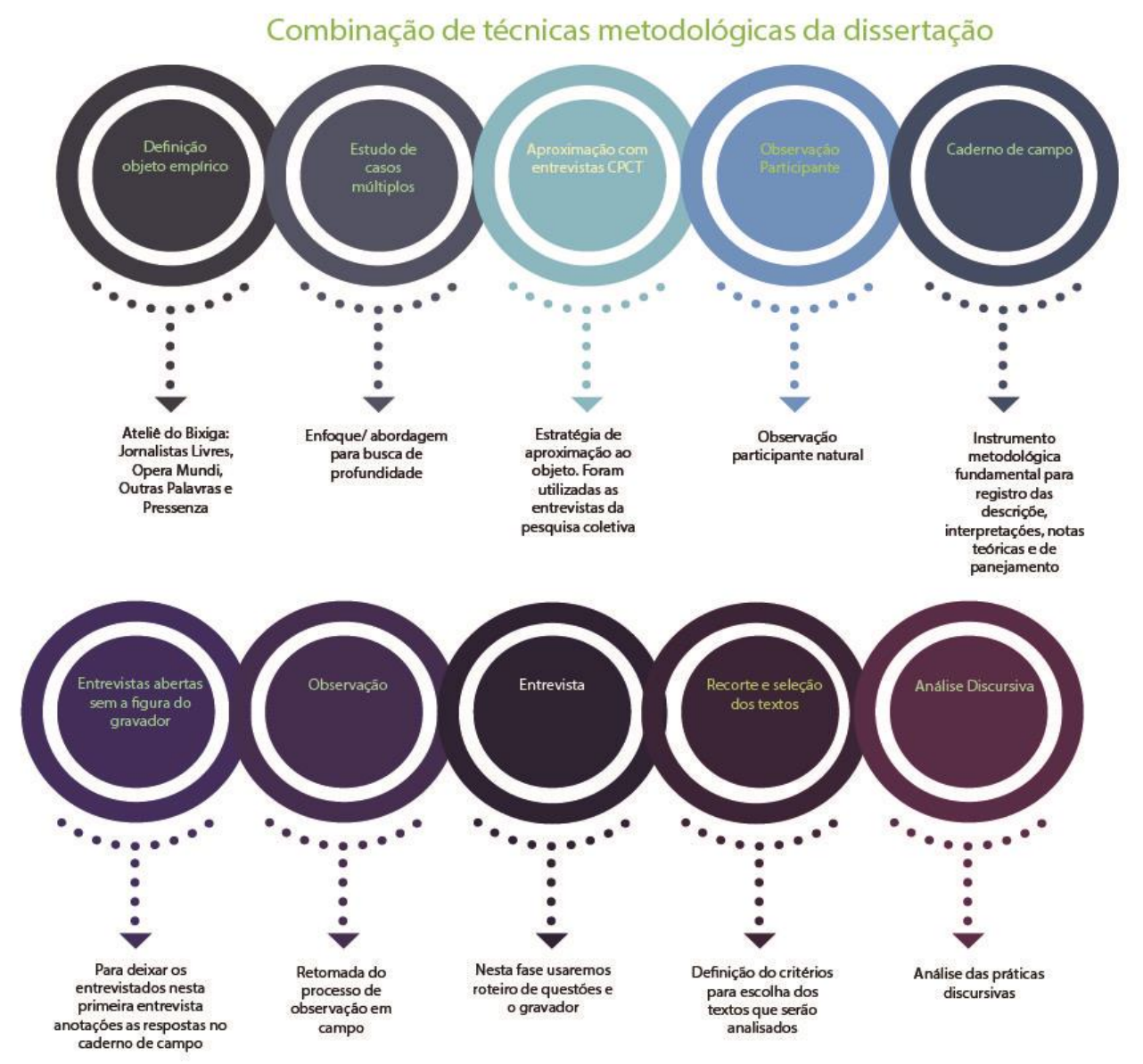

Figura 4 - Caminho metodológico - Fonte: Imagem da autora (2018)

A relação entre sujeito e objeto foi responsável pela escolha da observação participante como método da pesquisa.

Os sociólogos interacionistas sustentam que para "[...] melhor perceber as práticas e interações e interrogá-los em meio a ação é preciso usar a técnica de observação direta e a participante misturando-se e vivenciando ações sob a lógica dos atores [...]" que realizam a ação. Para Fortin apud Poupart (2008, p. 270), a observação participante é mais uma abordagem de pesquisa do que um simples método de coleta de dados.

Segundo Poupart (idem, pp. 258-259), a observação direta foi muito utilizada no final do século XIX, na França. Em 1950, a forte tendência do empirismo quantitativo e o funcionalismo contribuíram para que a abordagem entrasse em certo declínio; em 1960, a 
observação participante “[...] recebe uma espécie de conhecimento atribuível, em partes aos contra limites da sociologia empírica quantitativa [...]”; e em 1970, o “[...] recurso à observação se expande ainda mais no campo da pesquisa social [...]”, muitas vezes por ser a única abordagem possível.

Poupart evoca Laperriere (idem, p. 261) para descrever como ocorre esse processo para indicar o progresso da observação participante até a formação de coesão para indicação de atores, lugares e atos significativos para análise.

Para Gil (1999), a observação participante pode ser "natural ou artificial". Natural quando o pesquisador faz parte da mesma comunidade ou grupo e artificial quando se integra à comunidade para realizar a observação.

Decidimos por essa técnica devido à facilidade ao acesso de informações e à captura da descrição dos acontecimentos e contexto no ato, sem que fosse preciso intermediação para ter acesso aos dados. Contudo, foi importante refletir sobre quais elementos deveriam ser "ressaltados" ao mesmo tempo em que foi preciso estar aberto para as características somente ficarem evidentes no curso da pesquisa, ou seja, foi preciso ter postura epistemológica aberta para a pesquisa dialogar com o pesquisador sem as categorias estarem pré-concebidas.

Nesse sentido, a observação participante, em nosso caso, foi natural, pois habitamos o ambiente observado. A observação foi contínua e longa, com visitas, reuniões, conversas em cenários mais descontraídos e observação em grupo de sites de redes sociais. Observamos o funcionamento da casa e de cada um dos arranjos analisados, os modos de organização do lugar, o funcionamento, o relacionamento entre as diferentes iniciativas baseadas no Ateliê, a rotina de cada uma delas, horários, hábitos, formas de organização. Também foram feitas conversas sem a presença do gravador, participação em reuniões de pauta, observação in loco para acessar as informações sobre como se organizam e trabalham os jornalistas na comunicação alternativa.

Faz parte desse processo de observação e escuta, para descortinar os significados de maneira clara, distinguir o que é uma descrição e o que é a nossa própria interpretação após ficar muito tempo "em mergulho" no espaço de observação. O registro e uso do caderno de campo contribui com o amadurecimento do pesquisador ao reaprender a enxergar e, mais ainda, saber ouvir e deixar ser direcionado de forma aberta às múltiplas dimensões que podem se apresentar na investigação. 
Para não perder as informações coletadas foi importante registrar todas as descrições e interpretações em um caderno de campo com as descrições, interpretações e dados. A imersão no Ateliê do Bixiga proporcionou perceber os espaços comuns, a dinâmica do espaço, como se relacionam os trabalhadores que compartilham o mesmo local todos os dias por, no mínimo, oito horas diárias.

Após a releitura, identificamos o tipo da nota em: a) sequência descritiva, b) interpretativa teórica, c) nota metodológica e d) nota de planejamento para dar mais coesão e organização às ideias. Nas notas descritivas, relatamos diálogos, expressões gestuais, faciais, as disposições do Ateliê, os móveis, enfim, principalmente como método de capturar o detalhe e o particular de cada situação. As notas interpretativas são utilizadas para anotar as nossas impressões, reflexões, inferências acerca de alguma teoria, como refletimos o que estamos observando e as relações com outros dados observados para investigarmos posteriormente

A nossa participação em debates comuns com as lideranças dos arranjos é anotada como interpretação. As notas acerca do método que utilizamos são usadas como forma de garantia de vigilância das abordagens e instrumentos para ampliar a qualidade da pesquisa. As notas de planejamento, da mesma forma, são feitas para nos lembrar de providências, agendamento de reuniões e entrevistas seguintes, ideias que merecem ser revisitadas para melhorar a prática da pesquisa.

De acordo com Geertz, esse processo é similar ao de “[...] contar histórias e que o fato não se perde, ainda que o literalismo se perca":

Na etnografia, a análise, o pensamento, a escrita e a teorização estão vinculadas a
esta conceituação dos dados como uma coisa (frequentemente) intangível, elusiva,
circunstancial. Não é um processo padronizável. Em lugar disso, o próprio processo
de análise, interpretação e escrita em etnografia é equiparado a "contar histórias",
também a "fazer imagens, inventar simbolismos e posicionar tropos. (...) Estas
histórias são as elaborações que o pesquisador faz das elaborações de outros e os
aspectos salientes da linguagem que os etnógrafos 'representam' como versões do
real. (GEERTZ, 1973, p. 25)

$\mathrm{Na}$ prática é assim que rompemos com a visão dogmática, afastando todo o pensamento que é dado, determinado e imutável. O objeto e a prática conduzem junto com o pesquisador os rumos da pesquisa.

\section{Entrevista}


No total, fizemos 16 entrevistas com os membros do Ateliê e os membros dos veículos de comunicação. O processo de entrevista foi chancelado como método da pesquisa em Ciências Sociais a partir da Escola de Chicago e é considerado por Poupart “[...] como recurso para a compreensão das realidades sociais e uma grande vantagem das ciências sociais sobre as ciências da natureza." A entrevista pode ser encarada como uma coprodução, fruto do acordo tácito entre entrevistador e entrevistado para buscar o conhecimento de um fenômeno que interessa aos dois atores.

O autor lista os principais motivos para recorrer a essa técnica de coleta:

O primeiro é de ordem epistemológica: a entrevista de tipo qualitativo seria
necessária, uma vez que uma exploração em profundidade da perspectiva dos atores
sociais é considerada indispensável para uma exata apreensão e compreensão das
condutas sociais. O segundo argumento é de ordem ética e política: a entrevista de
tipo qualitativo parece necessária, porque ela abriria a possibilidade de compreender
e conhecer internamente os dilemas e questões enfrentados pelos atores sociais.
Destacam-se, por fim, os argumentos metodológicos: a entrevista de tipo qualitativo
se imporia entre as ferramentas de informação capazes de elucidar as realidades
sociais, mas principalmente, como instrumento privilegiado de acesso à experiência
dos atores. (POUPART, 2008, p. 216)

O processo de entrevista foi utilizado para ampliar o "nosso ouvido", observar e alargar a nossa compreensão dos casos estudados. Mais do que a relação unilateral entre entrevistador e entrevistado, a entrevista cumpriu o papel de observação dos "fios ideológicos" (VOLOCHINOV/BAKHTIN, 2014) das respostas, como o sujeito se relacionou com o espaço da entrevista, como se relaciona com outros membros dos arranjos e também na verificação de comportamentos, sentimentos e pistas de novos dados e padrões de ações.

É através das entrevistas que conseguimos captar as percepções sobre o trabalho, os dilemas enfrentados, o lugar do indivíduo e o papel do coletivo e, principalmente, a reflexão sobre o trabalho, seus sentidos e a formação de valores e concepções sobre a visão de mundo.

\section{O desafio da pesquisa na internet}

Durante o trajeto de pesquisa, a internet é parte central na produção do discurso e mediadora do trabalho jornalístico. Geralmente, os espaços virtuais de trabalho são organizados sem burocracia e o objetivo é a troca frequente de informações sem a necessidade de procedimentos complexos. Basta ter um aparelho com conexão para entrar na "[...] teia gigantesca que desfaz pontos fixos ou limites predeterminados para o tráfego de dados e imagens; não há nela centro ou periferia, e sim entrelaçamentos de percursos.” (MORAES apud COUTINHO, 2008. p. 42) 
Portanto, podemos inferir que o elo entre as diferentes técnicas é o espaço da conectividade. Basta usarmos como exemplo um motorista de transporte por aplicativo que não sai do lugar se não houver conexão ou uma jornalista que não consegue enviar a sua matéria após acompanhar um fato fora da redação. Para Ilse Scherer-Warren (2005, p. 80), há três aspectos das redes:

1) temporalidade: novas formas de comunicação em tempo real, com conexão entre diferentes tempos sociais; 2) espacialidade ou criação de territorialidades (do local ao global); 3) sociabilidade ou formas de relações sociais em termos de alcance, intencionalidade e conectividade com novas dimensões na esfera pública.

Além da análise desses espaços de organização do trabalho, as redes cumprem papel na produção da matéria jornalística que buscam seguir as métricas do duopólio da internet (Google e Facebook) e modificam até a linguagem como trabalho ao assimilar e criar verbos em torno dos nomes dos aplicativos, por exemplo, "telegramar" ou "basear" que veremos a seguir. ${ }^{13}$

Compreender as práticas relacionadas à internet tem, portanto, grande relevância para entendermos como os sujeitos estão compartilhando e atribuindo significado ao mundo, como é esse processo dialógico (VOLOCHINOV/BAKHTIN, 2014) de construção de sentidos no processo de realização conjunta, viver junto, construir socialmente sua visão de mundo.

O conceito técnico "práticas" é utilizado para retratar o comportamento rotineiro e, segundo Reckwitz (2002, p. 186) “[...] as práticas são maneiras rotineiras de se movimentar o corpo, manusear objetos e usar coisas, compreender e descrever o mundo, desejar e conceber tarefas e objetivos, de tratar pessoas e assim por diante."

Isso não quer dizer que vamos encarar a prática como monolítica ou imutável. A atividade humana é sempre inédita (SCHWARTZ; DURRIVE, 2008), embora também haja elementos de permanência e unidade na própria "rotina".

Fizemos essa explanação para apontar que "práticas na internet" será usado ao invés de "práticas on-line", o que abre uma lacuna entre o comportamento na rede e o da realidade como se fossem totalmente diferentes ou opostos.

Outro conceito relevante é o de "investigação conectiva" que relaciona o que fazemos online com as atitudes que temos quando estamos off-line. Para Coiro, Lankshear e Knobel (2008, p. 33), é preciso dissolver esse distanciamento:

${ }^{13}$ Nos capítulos III e IV discorreremos mais sobre esse assunto. 
[...] é preciso demonstrar os pares online/off-line, mundo virtual/ mundo real e ciberespaço/espaço físico. Em parte, eles são distinções imperfeitas e imprecisas (...) Não se deveria tomar o grau em que algumas pessoas parecem mesmo considerar diversas relações na internet um mundo à parte do resto de suas vidas como o ponto de partida para a investigação, mas vê-lo como algo que tem de ser explicado socialmente como uma realização prática (grifo do autor).

A prática na internet mobiliza objetivos, relacionamentos, materiais e recursos tangíveis e intangíveis que compõem a prática social. Esse aspecto foi notável na observação da redação virtual que desenvolveremos a seguir, nos capítulos III e IV.

Deriva também desse aporte conceitual a ideia de "espaços de afinidade" (JAMES GEE, 2004) como forma de delimitação espacial para observação de como os sujeitos sistematizam e adquirem conhecimento nas práticas relacionadas à internet. Conforme James Gee (2004, p. 81):

[...]são espaços projetados que foram construídos para atender as pessoas que têm em comum um determinado interesse ou empenho (afinidade). São espaços sociais ao qual os membros de uma afinidade podem "filiar-se" para compartilhar e adquirir conhecimentos, interagir, localizar recursos etc. São nem tanto locais quanto "ambientes" dispersos que servem às suas respectivas afinidades.

Mais de 127 milhões de pessoas no Brasil utilizam aplicativos de rede fechada como o WhatsApp e Telegram, em que milhares de grupos se organizam por afinidade, conhecimentos, interesses comuns ou por projetos.

Entre os jornalistas, o tema do grupo é uma categoria importante que organiza esses espaços. Por exemplo, na cobertura do Primeiro de Maio, Dia do Trabalhador, os Jornalistas Livres abriram um chat específico para tratar desse assunto, assim como o Opera Mundi, quando o assunto predominante foi uma eleição internacional. Desse modo, o assunto pode ser considerado a porta de entrada para as pessoas interessadas.

Essa porta não fica sempre aberta é preciso ter um "porteiro ou alguém que lhe dê a chave", isto é o link de ingresso ou que coloque novos membros dentro dos chats. Esse é o papel dos administradores dos grupos que podem representar a si próprios ou uma instituição. Cumprem o papel de incentivar a afinidade e, consequentemente, o interesse pelo espaço. São fontes que Gee (2004) denomina de "geradores".

Adicionamos ao conjunto de técnicas metodológicas o conceito de Dominique Maingueneau de dispositivo comunicacional. Nas palavras do próprio autor:

Quando tratamos do mídium de um gênero de discurso, não basta levar em conta seu suporte material no sentido estrito (oral, escrito, manuscrito, televisivo etc.). É necessário também considerar o conjunto do circuito que organiza a fala. A comunicação não é, com efeito, um processo linear [...]. Na realidade, é necessário partir de um dispositivo comunicacional que integre logo de saída o mídium. O 
modo de transporte e de recepção do enunciado condiciona a própria constituição do texto, modela o gênero do discurso. (MAINGUENEAU, 2001, p. 72)

Dessa forma, utilizamos o dispositivo comunicacional como conceito metodológico capaz de nos fornecer os elementos que são envolvidos em cada situação de fala, além dos aspectos linguísticos, compreendendo o discurso como uma formação social e não individual, o modo como o dispositivo incorpora o mídium (meio em comum e o instrumento), a circulação do sentido do discurso e as condições de produção, consequentemente como rege o conjunto do processo comunicacional.

Agora que já explicitamos as operações metódicas e metodológicas, vamos mergulhar nas dimensões históricas e sociais do papel da comunicação alternativa. 


\section{CAPÍTULO II}

Mídia alternativa: um olhar histórico da contra-hegemonia na comunicação 


\section{O conceito de comunicação alternativa do ponto de vista histórico e social}

Para compreender o que é a comunicação alternativa percorremos um caminho histórico para analisar características que são estruturais nas experiências desse tipo de comunicação. É importante salientar que cada veículo jornalístico estava ou está inserido em contexto próprio e determinado que auxilia no entendimento sobre o que é mídia alternativa.

Ao utilizarmos o materialismo histórico e o conceito de hegemonia como uma chave de leitura histórica e de análise de processos, visamos superar a aparência imediata através de um salto dialético para construir a cientificidade de nosso objeto.

Ao olhar para alguns momentos da história econômica, política e social do Brasil, buscamos apreender os fatores que influem na formação dos meios de comunicação hegemônicos e os alternativos com o objetivo de compreender acerca das categorias do movimento que proporcionam o desenvolvimento das forças sociais e políticas ${ }^{14}$ que atuam por meio através da comunicação. Assim, nos debruçaremos sobre a mídia em suas diversas formas e não sobre todo o espectro da comunicação ${ }^{15}$.

Diante disso, cada atividade e formação de grupo de mídia estão relacionados pelo momento histórico que vive, numa dada circunstância histórica.

Se considerarmos o aspecto econômico e social como premissa dessa discussão, vamos desconsiderar trabalhar com o conceito de forma imutável, ou seja, um conceito fechado aos determinantes estruturais do todo e o impacto que tem na parte ou mesmo um conceito que flutua como um balão de ar esvaziado de sentido, servindo de maneira oportunista de acordo com as instabilidades e circunstâncias.

Nesse sentido, adotamos as indicações de Cheptulin:

Mas, à medida que se dá o desenvolvimento do conhecimento do objeto, a
característica global de seu conteúdo torna-se insuficiente e um estudo mais
detalhado dos diferentes momentos do conteúdo, assim como dos processos e
relações que constituem, torna-se necessário. O conteúdo decompõe-se em partes
qualitativamente isoladas, e a análise dessas partes conduz à necessidade de colocar
em evidência as leis de sua correlação mútua com o todo. Essas leis da correlação
das partes isoladas, com o todo que as contém, refletem-se nas categorias de "todo"

\footnotetext{
${ }^{14}$ Durante análise vamos usar a relação singular e geral; quantidade e qualidade; causa e efeito; necessário e contingente; conteúdo e forma; parte e todo; e as leis da essência e do fenômeno, contradição como unidade e luta dos contrários; negação da negação e possibilidade e realidade.

${ }^{15}$ Ao pesquisarmos o conceito de comunicação alternativa em bancos de teses e dissertações percebemos que cientificamente ele é tratado de maneira mais ampla do que usualmente utilizado pelo movimento social. Por exemplo, comunicação alternativa de jovens surdos, deficientes, na área das engenharias etc.
} 
e de "parte"; as leis da correlação das partes entre elas, no quadro do todo, refletemse nas categorias de "elementos" e de "estrutura". (CHEPTULIN, 2004, p. 270)

Como todo entendemos os elementos que compõem o quadro econômico, político, social e cultural de determinado período histórico.

Há uma linha de confluência entre os pesquisadores da mídia alternativa sobre a imprecisão conceitual, os limites de aplicabilidade e o fato de não haver uma definição que unifique os cientistas de maneira universal. A pergunta “alternativo ao quê?" é a questão que dá coesão às elaborações acadêmicas. A diversidade de métodos e de características para definir a comunicação alternativa demonstra a riqueza de se pesquisar um elemento contemporâneo e pulsante.

\section{Em 1987, Máximo Simpson Grinberg organizou o livro A comunicação alternativa}

na América Latina com artigos de um conjunto de especialistas. Na obra, a questão do conceito é enunciada de princípio. O autor defende:

De acordo com a fundamentação que faremos ao longo desse trabalho, cremos que o
alternativo é factível através de diferentes meios e formas de comunicação. Portanto,
quando falamos de opções, não nos referimos exclusivamente a meios que, por sua
natureza, sejam distintos do de massa. Ou, em outras palavras, não propomos uma
alternativa aos medias como tais, mas enquanto instrumentos do poder; e,
inversamente, o meio não é em si o alternativo (ou não o é necessariamente) mas o
instrumento de uma opção promovida por um grupo de pessoas ou por um setor
social (GRINBERG, 1987, pp. 19-20).

É preciso notar que o contexto histórico em que foi elaborado o referido livro é marcado pela luta pró-redemocratização do continente e, muitas vezes, o Estado representava o próprio monopólio de informação e de opinião.

Mas a problemática para definição do conceito pode começar pela observação da denominação adjetiva. Se é alternativo é ao quê? Ao monopólio da informação? À lógica transnacional da informação-mercadoria? Ao discurso dos meios privados?

Ao lado das questões que permeiam a definição sobre o que é alternativo está a análise da história social, política e econômica do país, ou seja, as condições concretas que influem na formação dos grupos de comunicação. Isso porque o alternativo é alternativo numa situação dada, estabelecida materialmente. Outro elemento da formação do alternativo é ao que ele se refere. A comunicação alternativa só existe em relação ao que se contrapõe, numa relação dialética convergente ao mesmo tempo que concorrem do ponto de vista da organização do trabalho e do papel do jornalismo para a sociedade. 


\section{O alternativo: um olhar histórico}

Durante breve revisita à história nacional, buscamos identificar o posicionamento dos jornais, arranjos de comunicação alternativa de outrora. A nossa chave analítica é perceber através da luta estabelecida na sociedade exemplos de veículos de comunicação que podem auxiliar a compreensão de outros meios alternativos e como eles se articulam com o alternativo hoje, do ponto de vista da produção e, consequentemente, com quais meios de produção.

Por exemplo, no período colonial no Brasil era proibida a formação de quaisquer “instrumentos coloniais", como eram chamados os negócios, gráficas ou arranjo com o objetivo de imprimir, a não ser aqueles dos colonizadores. Diferentemente do México e do Peru que conheceram a imprensa em 1539 e em 1583, respectivamente.

Nelson Werneck Sodré (2011, p. 155) defende que "[...] assim onde o invasor encontrou uma cultura avançada, teve que implantar os instrumentos de sua própria cultura [...] para substituir a cultura encontrada." Ainda de acordo com o autor, a cultura encontrada nos países da zona espanhola representava sérios riscos ao domínio.

Dois séculos após a chegada dos portugueses em 1706, no Recife, houve a tentativa de instalação da primeira tipografia de impressão no país; depois em 1746, um antigo impressor de Lisboa também se empenhou, mas segundo Moreira de Azevedo ${ }^{16}$ apud Sodré (idem, p. 68), “[...] mandou a corte aboli-la e queimá-la, para não propagar ideias que podiam ser contrárias ao interesse do Estado."

Enquanto isso, na Inglaterra propagava-se o debate sobre a liberdade de expressão, iniciado quase cem anos antes, em 1644, por John Milton que advogou pela primeira vez o direito de impressão, o direito de qualquer sujeito poder distribuir suas ideias em praça pública, usando as palavras speech (expressar) e print (imprimir). "Dai-me a liberdade para saber, para falar e para discutir livremente, de acordo com a consciência, acima de todas as liberdades.” (MILTON apud LIMA, 2000, p. 86)

Após séculos, esse debate ainda é atual. De que liberdade de expressão estamos falando? Liberdade de impressão, como defendeu John Milton? Qual é a liberdade daqueles 
sem os meios para imprimir? E como não confundir a liberdade de expressão da empresa com a de imprensa?

Do ponto de vista dos recursos materiais de produção, foi somente em 1808, conforme descreve Sodré (op. cit., p. 172) que o Brasil terá sua oficina de impressão legalizada quando D. João toma conhecimento de que, na confusão da fuga de Portugal, Antônio de Araújo havia colocado no navio o material necessário para montar uma imprensa, tendo como responsável um corpo de secretários do rei compondo, assim, a Administração da Impressão Régia. A primeira, a Gazeta do Rio de Janeiro, já nasceu sob censura prévia de Frei Antônio Arrábida, de padre João Manzoni, Carvalho e Melo e José da Silva Lisboa.

Três meses antes, Hipólito da Costa lançava o seu jornal Correio Braziliense em Londres devido à " [...] dificuldade de publicar obras periódicas no Brasil, já pela censura prévia, já pelos perigos a que os redatores se exporiam, falando livremente das ações dos homens poderosos." De acordo com a Coleção Correio Braziliense (2001), o Correio ficou reconhecido por "manifestar a sua independência" para alguns e por seu discurso "doutrinário" para outros pesquisadores do período joanino.

A Gazeta do Rio de Janeiro, embora fosse o veículo oficial da colônia, reproduzia as notícias de príncipes, de países europeus e modos de cultura que ficavam distantes da opinião pública e realidade brasileira. Já o Correio Braziliense tratava dos problemas nacionais, mas a partir do ponto de vista da burguesia inglesa. O jornal assumiu posições polêmicas, por exemplo, ao ter ficado ao lado de Portugal, defendendo a união entre os dois países, ação que retardava a independência brasileira e chegou a expressar claramente sua opinião sobre a independência e dizia que as reformas deveriam ser feitas pelo governo e não pelo povo, e o "aborrecia" a possibilidade de reformas populares.

Mesmo recebendo recursos e alinhado politicamente com a Inglaterra, podemos considerar o Correio Braziliense alternativo na época? Na correlação entre forças hegemônica e contra-hegemônica dentro e fora do país o veículo reclamava de recursos, meios de produção, preço do papel, liberdade de expressão e jogava a responsabilidade na monarquia de Dom João.

Mas em nível internacional, a relação de Hipólito da Costa com empresários britânicos demonstra que havia interesses externos no rumo do Brasil, com a instrumentalização política do veículo. Mesmo assim, o jornalista buscava adjetivar seu jornal como independente para 
legitimar o seu discurso. Nos dias atuais, essa tática comercial ainda é utilizada para reforçar um único modelo de jornalismo e deslegitimar outro, como podemos acompanhar no debate acerca de fake News. Um exemplo é o esforço de grandes empresas de comunicação ao acusar que quem produz notícia falsa são os veículos engajados, ou seja, a mídia alternativa.

Hipólito da Costa era comerciante e, embora usasse o seu jornal também para os seus negócios, reclamava do fardo de ter que fazer sozinho o periódico nas horas vagas, como mostra Sodré (2011, p. 47):

Agora, é essencial ao nosso argumento o declarar aqui que todo o incansável trabalho de redação, edição, correspondência, etc., etc., desse periódico tem recaído sobre um só indivíduo que, aliás, carregado de outras muitas e mui [sic] diversas ocupações, que se lhe fazem necessárias, já para buscar os meios de subsistência, que não pode ter nos escassos lucros da produção literária desse jornal, já para manter a sua situação no círculo público em que as circunstâncias o obrigam viver. ${ }^{17}$

O jornalista faz duas reclamações que poderiam ser extraídas de um diálogo contemporâneo entre trabalhadores da imprensa alternativa atual: a primeira é que faz praticamente sozinho o jornal; e a outra é que não vive das vendas da publicação, mas de outras atividades. $^{18}$

Com o absolutismo entrando em declínio, era preciso que outros jornais falassem das virtudes de Portugal e de Dom João VI como forma de rebaixar a campanha pela independência do Brasil. Assim, outros jornais foram criados, com escritores no país ou em Portugal para garantir a campanha e a disseminação da virtude dos reinados.

Nesse cenário de necessário aumento das impressões de jornais diversos, passam a ser criadas oficinas clandestinas com equipamentos vindos de outros países ou improvisados. Foi o que fez, em 1820, o português Manuel Joaquim Barbosa Pimenta e Sal, chapeleiro, que fundiu as letras e prelo em uma oficina importada no Recife. Ainda de acordo com Sodré (2011), foi dela que emanou o primeiro documento político que o autor caracteriza como "o início da imprensa brasileira". O documento foi impresso por dois frades, um inglês e um marinheiro.

[...] a 28 de março daquele ano, realmente era impresso ali o documento político conhecido como Preciso, em que José Luís de Mendonça afirmava as razões dos revolucionários e colocava o problema da liberdade, até aí posto em plano secundário, no processo da Independência (SODRÉ, 2011, p. 65)

\footnotetext{
${ }^{17}$ Aspas retirada do Correio Braziliense, p. 174, XXIII, presente na obra de Nelson Werneck Sodré.

18 Veremos no Capítulo IV outros elementos que compõem o quadro atual das relações de produção e o mundo do trabalho do jornalista na mídia alternativa.
} 
Além de Recife, contavam com tipografias Pará, Manaus, Bahia e Rio de Janeiro. Com condições de produção mínimas, a discussão sobre liberdade de expressão fez parte da luta pela independência, sendo tema de disputa entre Portugal e Brasil Colônia como maneira de formar a opinião pública contra a censura. Nesse cenário, porém, a corte de Lisboa proclamou a liberdade de imprensa depois ratificada por José Bonifácio.

Anos após as primeiras instalações, o movimento anarcossindicalista impulsionado pelos conhecimentos dos gráficos e a necessidade de imprimir os jornais para os trabalhadores chega a instalar tipografias de forma clandestina. Em paralelo histórico, atualmente, a clandestinidade marca o movimento de hackerativismo que produz novas ferramentas livres na internet.

A proclamação dizia que "[...] sem dependência de censura prévia, todo cidadão pode manifestar suas opiniões em qualquer matéria, contanto que haja que responder pelo abuso dessa liberdade nos casos e na forma que a lei determinar." (op. cit., 71)

O debate acerca da liberdade de expressão anunciava a necessidade de que, logo após a independência, o Brasil teria que formar a estrutura de Estado e dividir o poder que emanava desse processo. Os jornais passaram a se posicionar contrários ou favoráveis à independência. Depois disso, o problema que dividiu os grupos de mídia diz respeito ao grau de intervenção que Portugal poderia ter no país, no período de descolonização.

Embora esse processo tenha sido fecundo para o desenvolvimento da imprensa nacional, o nosso intuito não é perpassar por todos os órgãos criados e seu contexto histórico, mas evidenciar como a realidade concreta faz parte e intervém no desenvolvimento da mídia e demonstrar outra categoria da dialética que pode ser utilizada para a análise: a relação possibilidade e realidade.

A possibilidade só é capaz de tornar-se realidade quando houver condições determinadas, ou seja, um conjunto de elementos e fatores necessários para realizar a possibilidade. Sendo assim, sem a necessidade econômica e social de o Brasil seguir o seu rumo independente de Portugal, as condições para ampliar os meios de produção e os jornais impressos não estariam dadas ou seriam outras. Diferentemente do cenário atual aberto pelas tecnologias e a internet, as condições materiais para se ter um veículo de mídia outrora só poderiam ser realizadas com a possibilidade de impressão. 
Outro fato importante para o desenvolvimento da mídia alternativa foi a luta pela abolição da escravatura, em que a imprensa literária e a acadêmica retrataram a pauta abolicionista. Nas escadas e no jornal da Faculdade de Direito de São Paulo, o estudante e poeta Castro Alves bradava: "A praça, a praça é do povo, como o céu é do condor." A faculdade abrigava também o núcleo abolicionista Fraternização, que auxiliava juridicamente a libertação de escravos.

Faziam parte do círculo figuras que usaram a imprensa para a campanha pela abolição como Joaquim Nabuco, Rui Barbosa, Rodrigues Alves, Bezerra de Menezes, Teófilo Otoni, João Henriques de Lima Barreto (pai de Lima Barreto), Bernardino de Campos e José do Patrocínio. Destaque também para Luiz Gama e Sizenando Nabuco, que usaram os meios de comunicação para as ideias abolicionistas, como a folha ilustrada Diabo Coxo.

Haubrich (2016) evoca Carvalho (2009) para apontar que o primeiro jornal abolicionista foi O Homem de Cor, de 1833, elaborado por Francisco Paula Brito, tipógrafo, jornalista e editor que, em 1832, cinco anos após a lei que liberava a imprensa, implantou a sua Tipografia Fluminense de Brito e Cia. Além do jornal O Homem de Cor que, mais tarde, passou a se chamar O Mulato, também a sua tipografia foi responsável pela impressão do primeiro jornal dedicado às mulheres (A mulher do Simplício ou A Fluminense Exaltada).

Para Carvalho (idem, ibidem), “[...] as expectativas de seus redatores eram de mobilização da população negra e da esperança de tempos de mudança, com o anseio por ações efetivas e o respeito aos direitos básicos do negro como cidadão brasileiro." Outro exemplo de jornal que fez a defesa intransigente e imediata da abolição foi o Gazeta de Notícias, um jornal que teve alcance popular e chegou a ter tiragem de 40 mil impressões diárias em 1885.

Segundo Deslandes Carin e Oliveira Affonso (2014), a “[...] Gazeta chegava em ambientes como cortiços ou estalagens e era leitura garantida em bondes e barcas, popularidade inédita em uma capital de hábitos tão conservadores.” De acordo com Marialva Barbosa, “[...] o sucesso do jornal era devido ele ser barato, popular e fácil de fazer.” (2010, p. 27)

O tensionamento entre as forças contra e favoráveis à escravidão também faz parte do desenvolvimento da mídia que se colocava como alternativa àqueles que queriam a manutenção da escravidão como sistema econômico e usavam o jornalismo para fazer essa 
defesa. A correlação de forças contra a escravatura era adversa, mas mesmo em um longo período histórico, esse cenário foi alterado.

Tanto o popular Gazeta de Notícias quanto o jornal O Homem de Cor e depois O Mulato aturam para promover a igualdade racial. A luta contra o escravismo colonial juntamente com as bases do jornalismo, migrando para o modo de produção industrial são elementos que ajudam a compreender essa fase da imprensa brasileira.

Os mesmos anseios dos protagonistas e jornais abolicionistas são compartilhados hoje por diversos coletivos e veículos de mídia que tratam sobre a questão da promoção e defesa da igualdade racial, como Geledes, Alma Preta, Mulheres Pretas e os coletivos e veículos que cobrem a periferia e têm traços distintos do jornal de bairro e comunitário.

À luz da análise das condições de produção esses veículos são alternativos devido ao seu posicionamento entre a luta dos contrários, quanto ao discurso e ao papel do jornalismo colocado como organizador de uma parte da sociedade.

Assim como a mídia abolicionista de outrora e atual, outros tipos de imprensa podem apresentar características comuns e estruturais da comunicação alternativa, como a protagonizada pelos trabalhadores no curso histórico.

\section{Imprensa anarquista e imprensa operária}

Como vimos anteriormente, os gráficos jogaram papel no desenvolvimento dos meios de comunicação no período joanino e os trabalhadores da imprensa continuaram a sua função de ampliar os veículos impressos através do domínio do ofício jornalístico.

Após a abolição da escravatura, os imigrantes vindos para formar a mão de obra principal, sobretudo italianos, espanhóis e japoneses, traziam na bagagem o conhecimento do modus operandi "do fazer" imprensa.

O movimento operário formou assim, os seus próprios jornalistas, principalmente com a participação dos trabalhadores gráficos que, devido às características de sua profissão, além de conhecerem as atribuições necessárias para produzir o jornal, era uma categoria que sabia ler e escrever, eram bem remunerados, estavam em contato com os jornalistas e eram 
considerados "intelectuais" que trabalhavam em um serviço manual. Esse papel era desempenhado por eles em todo o mundo, como nos mostra Rodrigues (1968, p. 36):

\begin{abstract}
Dentre as categorias operárias propriamente ditas, destacavam-se os gráficos, altamente politizados e que sempre apresentaram ponderável influência anarquista. Sendo obrigatoriamente indivíduos alfabetizados, sua condição profissional era assim qualificada, não sendo poucos os gráficos - ou tipógrafos, como eram conhecidos na época - que se tornaram jornalistas ou adquiriram outra profissão intelectual. Em tais condições, apesar de não constituírem uma categoria profissional muito numerosa, os gráficos sempre exerceram posição de liderança.
\end{abstract}

Maria Nazareth Ferreira (1988) divide a história da imprensa em três fases: a primeira remete ao processo do início da urbanização do país e à vinda dos imigrantes que muitas vezes eram presos, deportados e refugiados políticos em seu país de origem e ampliaram as fileiras do anarcossindicalismo no Brasil; a segunda refere-se à fundação do Partido Comunista do Brasil, que orientava desde a sua fundação, os seus quadros para tornarem-se orgânicos nos jornais existentes ou na criação de outros; e, finalmente, a terceira, que é caracterizada na luta pós-ditadura militar com as bandeiras contra o alto custo de vida e em defesa das liberdades democráticas.

Essa caracterização feita por Ferreira pode ser tomada como modelo em perspectiva para o uso de uma classe dos meios de comunicação. É notório que a elaboração da autora estava relacionada ao momento em que o país debatia a Constituinte, após anos de ditadura militar e em que os sindicatos eram considerados alvos de qualquer ação com intuito de interferir na correlação das forças atuantes daquele momento. Hoje, novamente sob ataques que visam dissolver os sindicatos, é claro a ausência de política de comunicação nas entidades representativas que operam com visão instrumental da comunicação apenas como ferramenta isolada da disputa de sentidos no seio da sociedade.

Com o objetivo de pautar assuntos que não eram abordados pela mídia hegemônica da época, o papel da comunicação na disputa da sociedade começava a ficar claro em 1847 com a criação, por um grupo de intelectuais no Recife, do jornal chamado O Proletário, seguido do jornal fundado pela Associação dos Tipógrafos do Rio de Janeiro, em 1858.

Setores mais progressistas e intelectuais acompanhavam no Brasil o movimento que se dava em outras partes do mundo, inspirados no processo iniciado em 1905, com a tentativa de revolução na Rússia, experiência que só teria êxito em 1917. Dessa forma, o sindicalismo passou a defender a unidade dos trabalhadores e da sua imprensa. Esse processo resultou na criação, em 1906, da Confederação Operária Brasileira, dois anos depois, na fundação do 
jornal A Voz do Trabalhador e na criação de uma rede de comunicação própria em torno da luta pela emancipação do homem, conteúdo raro nos veículos impressos da época.

A preocupação de tornar públicas as reivindicações dos trabalhadores e, mais do que
isso, a necessidade de levar às fábricas, as oficinas e a todos os locais de trabalho o
ideal da emancipação social, forçou os mais ativos militantes de então a lançar novas
publicaçõos periódicas, muitas das quais para preencher lacunas deixadas por jornais
que haviam desaparecido e outras para incorporar aos existentes. (RODRIGUES,
1969. p. 308)

As dificuldades de sustentação faziam com que veículos surgissem e logo desaparecessem, saindo de circulação ou tendo espasmos de vida com longos intervalos. Esse fato pode ser apontado também na mídia alternativa atualmente. Sites são articulados e desarticulados a todo momento, apontando uma perspectiva curta, mesmo não sendo uma regra, são poucos os veículos de comunicação que existem há mais de dez anos.

Assim como atualmente no movimento dos blogueiros feito por jornalistas que saem da corporação de mídia e migram para a comunicação alternativa (LIMA, 2015), naquele período redatores militantes fundavam e atuavam em jornais que tiveram curto tempo de existência motivado pelas dificuldades financeiras, sem a venda de anúncio já que seu público eram os trabalhadores de baixo poder aquisitivo e havia a perseguição por parte do Estado.

Esses percalços financeiros e de recursos humanos acontecem até os dias de hoje. Os jornalistas que lideram experiências em arranjos alternativos, por exemplo, são esses redatores principais. Com poucas pessoas, sem estrutura e muitas vezes sendo alvo de forças do Estado - principalmente as jurídicas que ameaçam com processos os grupos de mídia. Também a periodicidade é afetada por indefinição e falta de regularidade. Essas características perduram, e como vimos anteriormente, não começou nesse período, sendo um dado geral que perpassa a história da comunicação alternativa brasileira.

A imprensa anarcossindicalista cumpriu o papel de imprensa política e alternativa. De acordo com Giannoti (1988), como não havia partidos de esquerda até 1922, quando nasce o Partido Comunista do Brasil, era essa imprensa operária anarquista que exercia o papel de imprensa política alternativa.

O conceito de mídia sindical e operária elaborado por Ferreira se dá sobre o tripé da luta da classe trabalhadora que, segundo a autora, é o jornal, o partido e o sindicato. A autora demarca que não é possível reduzir a imprensa operária à imprensa sindical, como se o discurso não fosse polifônico e dialógico, como se os sentidos não atravessassem as dimensões do mundo do trabalho. Em suas próprias palavras: 
O que resulta de significativo na existência da imprensa operária é o fato de que ela estará sempre ligada a alguma forma de organização da classe trabalhadora - seja partido, sindicato ou qualquer outra espécie de agremiação - circulando de maneira diferente da imprensa burguesa, ou grande imprensa. O veículo de comunicação da classe trabalhadora [...] não tem proprietário e a sua mensagem não é uma mercadoria a ser consumida [...]. O jornal é um instrumento de informação, conscientização e mobilização; o receptor não é um elemento passivo, mas alguém que tem interesses comuns e participa da mesma forma de organização: A comunicação torna-se um instrumento de intercâmbio, não de dominação. É horizontal e interativa (FERREIRA, 1988, p. 6)

Nessa idealização, encontramos outro traço comum - ou que deveria ser - que é a horizontalidade na organização. Dos quatro arranjos analisados nessa pesquisa há em maior ou menor grau a tentativa de tornar a pauta mais permeável aos leitores e a setores organizados com o uso de relações horizontalizadas. Vamos problematizar adiante, no Capítulo III, a forma de organização de cada arranjo pesquisado.

Retornando para o período posterior à constituição legal dos sindicatos, a perseguição por parte do Estado aumentava. Os comunistas, já na segunda fase definida por Ferreira, fundam em 1925 o jornal A Classe Operária e duas outras revistas, a Movimento Comunista e Revista Proletária, como forma de ampliar a politização e a mobilização. Alguns anos depois ainda criam o jornal A Nação, a revista Autocrítica e o jornal Luta de Classe.

Ainda nessa década, aconteceram episódios significativos para a história nacional: a Revolução dos 18 do Forte de Copacabana ${ }^{19}$, a Revolta Tenentista em São Paulo, que chegou a ocupar o Palácio do Campos Elísios, sede do governo estadual, e a Coluna Prestes, liderada por Luís Carlos Prestes, que exigia o fim do voto secreto, a defesa do ensino público e a obrigatoriedade do ensino primário para todos os brasileiros. Essas situações abriram uma fissura no bloco histórico que estava no poder desde então, sendo as oligarquias gaúchas a liderança do processo da Revolução de 1930.

Mas o que isso tem a ver com a questão da comunicação?

Com a revolução liderada por Getúlio Vargas, começou um período de construção do pensamento nacional nas instituições do Estado. A industrialização leva milhões pessoas a fazerem o caminho de saída do campo e se dirigirem à cidade.

\footnotetext{
${ }^{19}$ Deflagrada em cinco de julho de 1922 e que teve como estopim uma suposta carta de Arthur Bernardes, então candidato à presidência da república, em que ele ofendia o exército e o marechal Hermes da Fonseca. Arthur Bernardes representava a continuidade da política que favorecia os grandes fazendeiros e o acordo entre os mineiros e os paulistas, simbolizada na política do café com leite, quando os dois Estados revezavam-se no poder central.
} 
De acordo com Sodré (2011), essa etapa foi marcada pela substituição de importações, pelo crescimento do trabalho assalariado, pelo aprofundamento da acumulação primitiva. É desse período o marco de leis que têm o objetivo de proteger a indústria nacional e o desenvolvimento do mercado interno, além de mudanças de grande vulto que alteraram a estrutura econômica que passa de Estado essencialmente agrícola para um estágio industrial, ancorado na produção de bens de consumo e indústria leve.

O Estado foi indutor do desenvolvimento da indústria cultural através de políticas públicas de financiamento, criação da legislação e processo de organização e legitimação dos meios de comunicação como produtores culturais que tinham como objetivo "[...] transformar as massas em povo e povo em nação.” (LOPES, 1990)

Em 1932, Getúlio Vargas assinou a primeira lei que regulamenta a comunicação fora do tópico da censura e liberdade de impressão. A lei do rádio regulamentou a publicidade, antes proibida, visto que as emissoras eram associações educativas e de interesse público, portanto, não comercial. Eram mantidas por doações ou mensalidades dos ouvintes.

Ao liberar a publicidade no rádio, o modelo de negócio passou a ampliar o número de ouvintes e, consequentemente, sua influência política. Para os donos de jornais impressos muitos já faziam parte do Congresso Nacional - ter uma emissora de rádio representava ter um negócio lucrativo e aumento de influência política no seu domicílio eleitoral.

\footnotetext{
Em meados da década de 1930, o leitor está praticamente ausente das publicações. Sua fala é silenciada nos jornais, enquanto a fala do Estado é ampliada. Essa ampliação se dá através da constituição de um amplo aparato burocrático e repressor, via formação do Departamento de Imprensa e Propaganda (DIP). (BARBOSA, 2007, p. 108)
}

Atingindo a fase de ouro do rádio com o estímulo presidencial, a partir de 1950, com a implantação da TV, as emissoras de rádio começaram a mudar a sua estratégia de regionalização e segmentação de público.

As emissoras de televisão começaram a crescer no período da ditadura militar, com as concessões de outorgas e a criação da Empresa Brasileira de Telecomunicações, em 1965, que possibilitou, com a rede de telecomunicações e as estações repetidoras, a formação da cadeia de emissoras, dando origem à Rede Globo de Televisão.

O Estado sempre ofertou suporte para os veículos de comunicação. Sem a contribuição estatal, as condições para que os grupos de mídia tornassem empresas e posteriormente conglomerados seriam mais adversas. 
Concretamente, somente com a simbiose da política e comunicação como práticas de poder é que foi possível a modificação de empreendimento familiar para linha de negócios, que hoje agregam mais do que veículos de comunicação, aproveitando-se das benesses da financeirização do capital para ampliar lucro e rendimentos.

Próximo a esse período de criação de rede de aliadas e fortalecimento econômico, que chamamos aqui de conglomerados de mídia, poucos anos antes da ditadura militar, começava nas paróquias católicas uma nova forma de comunicação popular visando atingir o mesmo público da imprensa sindical, mas com outro discurso através das comunidades eclesiais de base $^{20}$, importante experiência para a mídia alternativa.

São comunidades, porque reúnem pessoas que têm a mesma fé, pertencem à mesma igreja e moram na mesma região. Motivadas pela fé, essas pessoas vivem numa comum-união em torno de seus problemas de sobrevivência, de moradia, de luta por melhores condições de vida e de anseios e esperanças libertadoras. ${ }^{21}$ (FREI BETTO apud FESTA, 1981, pp.178-179)

A experiência nas CEBs faz parte da base da práxis social da comunicação do Movimento Sem Terra e tem grande influência no jornalismo comunitário atual. Para realizar os debates, práticas e o viver em "comunhão" era preciso se comunicar com a comunidade e com o povo sobre as "esperanças libertadoras".

Com o mesmo intuito, o jornal semanal Brasil Urgente foi lançado pela igreja católica em 1963, por frei Carlos Josaphat, e chegou a ter uma tiragem de 40 mil exemplares.

As experiências do jornalismo feito por coletivos de periferias como Agência Mural, Nós, Mulheres da Periferia e Periferia em Movimento buscam estabelecer e construir essa identidade das comunidades através das redes, mas principalmente ao retratar o território em que estão inseridas.

\footnotetext{
${ }^{20}$ As comunidades eclesiais de base (CEBs) são pequenos grupos organizados em torno das paróquias (urbana) ou capela (rural), por iniciativa de leigos, religiosos ou bispos. As primeiras surgiram por volta de 1960, em Nísia Floresta, arquidiocese de Natal (RN), segundo alguns pesquisadores, ou em Volta Redonda (RJ), segundo outros. De natureza religiosa e caráter pastoral, as CEBs podem ter dez, 20 ou 50 membros. Nas paróquias de periferia, as comunidades podem estar distribuídas em pequenos grupos ou formar um único grupão, a que se dá o nome de comunidade eclesial de base. É o caso da zona rural, onde 100 ou 200 pessoas se reúnem numa capela, aos domingos, para celebrar o culto.

${ }^{21}$ São eclesiais porque congregadas na igreja, com núcleos básicos de comunidade de fé. São de base porque integradas por pessoas que trabalham com as próprias mãos (classes populares): donas de casa, operários, subempregados, aposentados, jovens e empregados dos setores de serviço, na periferia urbana; na zona rural, são assalariados agrícolas, posseiros, pequenos proprietários, arrendatários, peões e seus familiares. Há também comunidades indígenas. Segundo estimativas não oficiais, existem no país, atualmente, 80 mil comunidades eclesiais de base, congregando cerca de 2 milhões de pessoas crentes e oprimidas. Para saber mais, sugerimos a leitura de $\mathbf{O}$ que é comunidade eclesial de base, de Frei Betto.
} 
Assim como em outros períodos, a repressão militar, alinhada ao projeto de intervenção dos Estados Unidos na América Latina, desloca a comunicação alternativa para cumprir o papel de propagar a resistência civil, como veremos a seguir.

\section{Imprensa nanica contra o grande bloco ditatorial}

Boa parte dos estudos acerca da mídia alternativa concentra-se nesse período da ditadura militar. Há alguns pesquisadores que creditam a esse momento histórico o nascimento da imprensa alternativa.

Segundo a tese de doutorado de Maria Alice Campagnoli Otre (2015), em 40 anos de pesquisa - o recorte foi o período de 1972 até 2012 - foram elaboradas 87 dissertações e 15 teses, totalizando 102 pesquisas sobre comunicação popular, alternativa e comunitária. ${ }^{22}$

Em um cenário em que era mais nítida a posição dos atores sociais divididos em dois campos, ficava mais fácil a classificação também da imprensa. Dessa forma, a imprensa monopolizada estava de um lado e a imprensa alternativa em outro. Falando de uma outra forma, em um cenário polarizado é mais fácil identificar quem compõe as forças sociais que estão em campo.

A expressão nanica, segundo Kucinski (2011, p. 5), foi disseminada por publicitários e inspirada no formato do jornal usado pela maioria dos jornais alternativos.

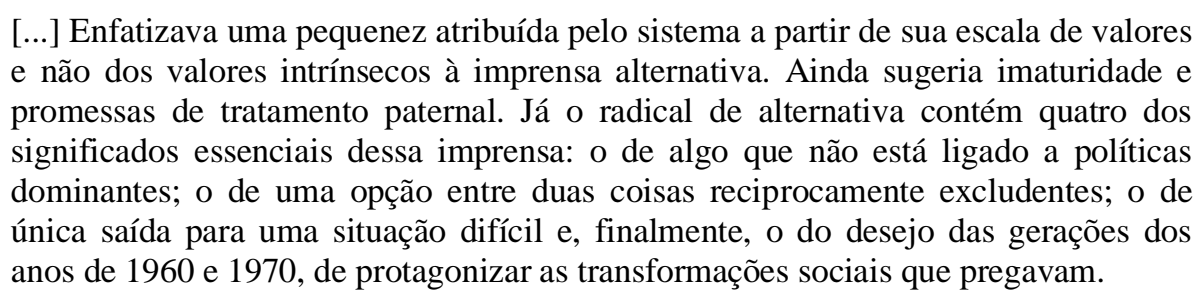

De acordo com o autor, a imprensa alternativa surgiu da junção do posicionamento contrário ao regime militar com as limitações que o autoritarismo impunha aos jornalistas no exercício da

\footnotetext{
22 Trabalhamos com a hipótese de esse número ser maior após o grande crescimento de novos arranjos alternativos de comunicação decorrente das manifestações de 2013, que mobilizaram milhares de pessoas em todo o país contra o aumento das passagens de ônibus. Foi em meio às manifestações que surgiu, por exemplo, a Mídia Ninja (Narrativas Independentes, Jornalismo e Ação).
} 
profissão e a mobilização das forças de esquerdas de transformar a realidade apoiadas nas mesmas crenças, ideologia e imaginário social.

Kucinski (2011) dividiu em duas as categorias de jornais alternativos. Os que faziam mais pautas políticas e reivindicavam a valorização do pensamento e da cultura popular nacional "[...] tinham raízes no marxismo vulgar dos meios estudantis dos anos 1960." Mesmo tendo uma linha "pedagógica e dogmática", como o autor classifica os jornais alternativos políticos, é justamente nas páginas desse tipo de jornalismo que há a denúncia do crescente endividamento externo já em 1973, a crescente pobreza diante da promessa do "extraordinário crescimento econômico". As cenas da população mais pobre, os chamados boias-frias, e o vigor do sindicalismo, ao lado de discursos criativos para diminuição da censura, faziam parte dos temas da imprensa alternativa.

Entre essas pautas, a discussão de estratégias e táticas para aberturas democráticas também pertenciam ao cotidiano da redação. A outra categoria anunciada pelo autor representava o movimento de contracultura norte-americano, no orientalismo, anarquismo e no existencialismo de Jean Paul Sartre. "Eram voltados à crítica dos costumes e à ruptura cultural, investiam principalmente contra o autoritarismo na esfera dos costumes e o moralismo hipócrita da classe média.” (KUCINSKI, 2011, p. 46)

A rejeição ao uso de discurso ideológico na comunicação era resultado, segundo Kucinski, do dogmatismo da esquerda. O ponto de confluência das duas categorias era a crítica ao regime militar.

Com o crescimento da repressão, os jornais sindicais e os movimentos de esquerda, que sustentaram outras fontes de informação e opinião, diminuíram nesse período, restando apenas alguns que operavam na clandestinidade. Exemplo da ferocidade dos militares foi a proibição do jornal Pif Paf, lançado por Millôr Fernandes, que sobreviveu apenas por oito edições. Entre 1968 e 1973 foram lançados os jornais Pasquim (1968); O Bondinho (1970), que era distribuído com apoio do Grupo Pão de Açúcar; Opinião (1972), do empresário Fernando Gasparian; Ex - que depois tornou-se Mais Um (1973); Jornal de Debates (1973) e Politika (1973).

Os jornais eram articulados com organizações políticas, no entanto, por abrigar jornalistas que não podiam exercitar a sua liberdade nas redações da mídia tradicional, estes traziam para o jornal alternativo a preocupação com a técnica e o fazer jornalístico, com as formas de retratar a realidade, fazer matérias, entrevistas, reportagens. 
Atualmente, da mesma forma, jornalistas que atuavam na grande imprensa passam a trabalhar na mídia alternativa, como é o caso do Jornalistas Livres e o Opera Mundi. Os limites do jornalismo e suas técnicas são temas frequentes dentro dos arranjos. O método de trabalho é baseado na questão: “o que e por que devem ser publicados determinados assuntos, fotos e linguagem?" Isso faz com que os eixos do jornalismo sejam tensionados a todo momento.

Inovações que surgiam na imprensa alternativa foram apropriadas pela mídia comercial, que utilizou as experiências para sua atualização técnica. São exemplos o uso de temas e problemas, expressões, conselhos editoriais, a participação de segmentos sociais etc.

Grinberg (1987, p. 34) cita, em seu livro, a intervenção "A trajetória da imprensa alternativa", de Argemiro Ferreira, feita durante o VI Congresso da Associação Brasileira de Ensino e Pesquisa em Comunicação (ABEPEC):

[...] várias coisas que davam vitalidade à imprensa alternativa foram absolvidas pela grande imprensa. Eu me lembro que, no tempo do Opinião, gente como Fernando Henrique Cardoso, como Weffort, como tanto outros, só podiam escrever em jornais como o Opinião. Nenhum jornal da grande imprensa publicava artigos dessas pessoas. [...] A própria página de artigos da Folha de São Paulo é bem um sintoma dessa adaptação que se processou na grande imprensa [...]

A seção do Jornal Nacional intitulada "O Brasil que eu quero, solicitando que o público envie vídeos, com a informação do nome e da cidade, com a filmagem no formato horizontal, mostrando o que o telespectador gostaria de mudar no país, seguiu a mesma orientação de coletivos, como o chamado feito pela Agência Pressenza, que fica colado em paredes de faculdades de comunicação ou escolas técnicas. Veremos, no Capítulo III, a participação de leitores na produção da matéria nos arranjos alternativos.

Poucos jornais da imprensa alternativa tiveram vida longa durante a ditadura militar e, muito menos, preservado o seu projeto editorial. O caderno especial sobre o tema produzido pela Prefeitura do Rio de Janeiro, intitulado Imprensa alternativa: apogeu, queda e novos caminhos, de 2005, relata que do "[...] universo de 160 jornais, surgidos na década de 70, a metade não chegou a completar um ano de existência e que apenas 25 tiveram até cinco anos." (2005, p. 17)

O processo de democratização e abertura de novo ciclo político no país fez com que alguns veículos da imprensa comercial passassem a defender algumas bandeiras que só eram veiculadas na mídia alternativa como, por exemplo, a anistia e eleições diretas. A entrada da Folha de S. Paulo na campanha das Diretas Já foi uma evidência dessa mudança de posição. 
Mesmo nesse processo de abertura, as bancas que costumavam vender os jornais da imprensa alternativa sofreram uma série de ataques com bombas, na década de 1980, passando a recusar a venda desse tipo de jornal, acabando com a principal fonte de renda dos veículos.

Com a abertura política, os jornais de sindicatos, partidos e entidades que tinham sido proibidos voltavam a circular e a receber a contribuição de muitos jornalistas que construíram a mídia de resistência durante o regime militar.

É importante ressaltar que o desenvolvimento tecnológico que começava a engatinhar, relacionado com o processo e dinâmica da internacionalização do capital ainda na década de 1960, possibilitou mudanças na mídia tradicional, mas também na mídia alternativa, tornando possíveis processos que antes eram mais caros e inacessíveis.

Gorgen (2009 p. 74) afirma que as modificações não pararam desde então, transformando o setor das comunicações de maneira rápida:

Tanto em termos tecnológicos quanto em modelos de negócios, rádio, TV e imprensa presenciavam, no Brasil, o desembarque de duas mídias que iriam alterar a forma com que a humanidade passaria a se comunicar: a TV por assinatura e a internet, ambas proporcionadas pela infraestrutura de redes.

Com a internet, segmentos se apropriaram das tecnologias de informação e comunicação no movimento chamado por Dênis de Morares de "verdadeira revanche sociocultural". A internet poderia ser, segundo o professor da Universidade Federal do Rio de Janeiro, a "construção de uma contra-hegemonia mundial", mesmo sabendo que a internet está relacionada com a situação da transnacionalização da comunicação.

É um erro supor que as aberturas na internet possam sobrepujar o cenário de transnacionalização da comunicação, inclusive no campo virtual, em que as corporações midiáticas fincam sem tentáculos com agressividade, controlando os sites mais populares, e com isso atraindo crescentemente anúncios e patrocínios. (MORAES, 2008, p. 54)

Hoje, mais de dez anos após tal formulação, podemos afirmar que a financeirização na comunicação se dá muito além do controle de sites mais populares, mas com o papel para acelerar o processo de distribuição de mercadorias na complexa e poderosa economia de dados, em que as informações daqueles que navegam pela internet são a principal moeda, os bancos virtuais de bitcoins ou mesmo a chamada deep web que tem sido espaço de articulação de forças ultraconservadoras e de falsificadoras de arquivos para manipular acontecimentos e eleições em todo o mundo. Mas esse é outro debate que pode ser desdobrado em futuros 
estudos. Voltemos para a discussão da mídia alternativa agora já no tempo atual da internet.

\section{Salto para os tempos da internet}

Pela primeira vez no Brasil, o último relatório do suplemento Tecnologias da Informação e Comunicação da Pesquisa Nacional por Amostra de Domicílios (Pnad) ${ }^{23}$, divulgado em 2018, apontou que 69,8\% de brasileiros com dez anos ou mais (181 milhões de pessoas) acessaram a internet de 2016 para 2017. O crescimento de mais de 10 milhões de usuários ocorreu em todas as regiões e faixas etárias, sendo a banda larga móvel mais usada por 78,5\% como conexão diante de 73,5\% de banda fixa. Segundo Bianchi e Borges (2014), calcula-se que a cada dia surgem cerca de 100 mil blogs no mundo, que se somam às mais de 250 milhões de páginas pessoais já existentes.

Aliado ao crescimento do acesso à internet, em que pese a ausência de políticas públicas que estimulem o uso e a redução dos custos da banda larga no país, o que faz com que o serviço utilizado pela população brasileira ainda seja um dos mais caros do mundo, o fechamento de postos de trabalho nas redações das corporações de mídia tem refletido na busca de recémformados e novos jornalistas por espaços de trabalho em que as relações de trabalho e o tratamento da notícia sejam diferentes da rotina das empresas de comunicação.

As ferramentas de produção da notícia ficaram mais baratas com as novas tecnologias, o que possibilita uma janela de oportunidades para que profissionais da comunicação possam concretizar inovadoras experiências quanto à forma de produção de conteúdo jornalístico.

Dentre essas experiências, a comunicação em torno do Fórum Social Mundial (FSM) ${ }^{24}$ pode ser considerada um marco para a mídia alternativa brasileira. Foi na organização do FSM que as coberturas colaborativas começaram a adotar método colaborativo através de um software livre que gerava diferentes senhas para alimentar o site na atividade mundial. Nos eventos, havia

\footnotetext{
${ }^{23}$ Fonte: Agência de Notícias do IBGE. Disponível em https://agenciadenoticias.ibge.gov.br/agencia-sala-deimprensa/2013-agencia-de-noticias/releases/23445-pnad-continua-tic-2017-internet-chega-a-tres-em-cadaquatro-domicilios-do-pais. Acesso em 20/12/2018.

${ }^{24}$ Fórum Social Mundial (FSM) é um evento organizado por movimentos sociais de diferentes continentes com objetivo de elaborar alternativas para uma transformação social global.
} 
reuniões para organizar a cobertura, a distribuição de atribuições para repercutir a atividade que se contrapunha ao Fórum Econômico de Davos. ${ }^{25}$

Diante do embate com fortes setores econômicos, a questão principal para os ativistas da comunicação do FSM era como circular o conteúdo, o que acontecia nos espaços de atividades, como reverberar a formulação do movimento social para construir "outro mundo possível", como preconiza o slogan da organização. Como descreve a jornalista que participa até hoje no coletivo de comunicação Ciranda, fundador do jornalismo colaborativo no país:

\begin{abstract}
Naquele momento você não tinha uma rede, você não tinha nem a possibilidade de pessoas de diferentes lugares postarem no mesmo site. Naquela época isso não existia. 2001, olha! Faz pouco tempo. Mas quem tinha criado isso era o Indymedia dois anos antes em 1999 que fez um site para iniciados - que eram os anarquistas que estavam ali que falavam alguma coisa da conferência desse ato e eles podiam entrar, então eles escreviam ali. Então, aqui um grupo que saiu da Universidade Federal do Rio de Janeiro criou um escritório chamado Fábrica Digital e um sistema que poderia ser alimentado simultaneamente por pessoas diferentes, e nós pegamos essa experiência e levamos para o Fórum Social Mundial. (Entrevistada da Ciranda, 2017, CPCT/ECA-USP) ${ }^{26}$
\end{abstract}

Desse processo colaborativo nasceram outras experiências de mídia na internet como a Revista Fórum (atualmente é um site e não mais impresso), a própria Ciranda, o Outras Palavras, analisado nesta dissertação, e Carta Maior. Mais de 800 pessoas participavam da cobertura colaborativa, ligadas às organizações ou não, e cada uma tinha um papel no processo de produção da narrativa que envolvia e era decidida no FSM. Isso se expressa até na nomeação das editorias do Outras Palavras (Outras Mídias, Outros Quinhentos etc.) também objeto de análise do Capítulo III.

É também contribuição do Fórum Social Mundial a formulação sobre mídia livre. Tal ideia inicia-se nesse espaço de colaboração e práticas jornalísticas, sendo fundado nesse percurso o Fórum Mundial de Mídia Livre, que descreve esse tipo de mídia como:

Praticamos novas formas de comunicação humana, intercultural, horizontal, não-violenta, aberta, descentralizada, transparente, inclusiva e compartilhada, através de múltiplos instrumentos e formas de expressão (rádio, televisão, audiovisual, imprensa, internet etc.), experimentando novos modos de organização e produção de informação. Nossas fontes de financiamento, quando existem, não condicionam nossa maneira de comunicar nem nossa linha editorial. Estamos conscientes de que o termo "mídia livre" remete a diferentes interpretações em função de diversas realidades linguísticas e culturais. Nós o escolhemos, antes de mais nada, porque ele nos reúne em torno de práticas comuns,

\footnotetext{
25 Fórum Econômico Mundial (FEM) é uma organização internacional localizada em Genebra (Suíça), responsável pela organização de encontros anuais com a participação das maiores e principais empresas do mundo com governantes para alinhamento e negociação econômica.
}

\footnotetext{
${ }^{26} \mathrm{O}$ depoimento faz parte da pesquisa As relações de comunicação e as condições de produção no trabalho de jornalistas em arranjos econômicos alternativos às corporações de mídia. Ver mais em http://www2.eca.usp.br/comunicacaoetrabalho/cpct-eca-usp-apresenta-resultados-de-pesquisa-sobre-novosarranjos-alternativos-de-trabalho-no-jornalismo/
} 
baseadas na busca por autonomia diante das lógicas comerciais ou estatais, na luta contra todas as formas de dominação e no desejo de garantir espaços de expressão abertos. Queremos construir modelos econômicos solidários e sustentáveis. (Carta Fórum Mundial De Mídia Livre, Tunísia, 2015) ${ }^{27}$

De lá para cá, 18 anos depois, as redes mudaram muito a forma de produção da matéria jornalística. A partir de 2002, o Brasil viveu um período de crescimento econômico e de distribuição de renda, com repercussão na forma de aquecimento do mercado de internet.

O meio de produção mais elementar de nossos dias - o celular - torna acessível a produção de diferentes conteúdos como vídeos, fotos e textos. Com aplicativos de edição é possível fazer um vídeo razoável enquanto se está no ônibus, por exemplo. Há no país mais celulares do que gente, sendo 229 milhões de aparelhos. ${ }^{28}$ Isso não quer dizer que todos os brasileiros tenham celular, mas demonstra o acesso a esse meio, que hoje é considerado para muitos como conexão ao trabalho (como para motoristas de Uber, entregadores etc.) e também como meio de produção do trabalho jornalístico, como veremos nesta pesquisa.

Nesse ínterim, as formas de comunicação são ampliadas. Jornalistas egressos dos conglomerados de mídia migram para a chamada "blogosfera" e fundam espaços de notícias ou de artigos de opinião na internet. ${ }^{29}$

Entre os arranjos pesquisados em São Paulo, pelo Centro de Pesquisa em Comunicação e Trabalho (CPCT), oito foram fundados em 2013, 14 em 2014 e outros 12 em 2015. A partir dessa amostra, podemos inferir que 2013 contribuiu abrindo um novo momento, mas é com o acirramento político promovido no processo de impeachment da ex-presidente Dilma Rousseff que essas experiências são alargadas. Outra contribuição da pesquisa é a evidência sobre quem trabalha nesses arranjos.

Os resultados parciais da primeira etapa da pesquisa mostram que os/as jornalistas são jovens (a maioria), que há um número expressivo de mulheres fundadoras e dirigentes, a maioria tem diploma de jornalismo e busca trabalhar no jornalismo, organizando alternativas. São iniciativas recentes com menos de cinco anos, sobretudo, apareceram no período entre 2011-2015, estimulados pela ampla margem de recursos para o trabalho em plataformas digitais. (FIGARO, 2018, p. 61)

A partir de autodeclaração de 70 arranjos componentes na pesquisa, a maioria não se declarou como alternativo (33), mas 27 se declaram como independentes; somente sete julgaramse inovadores e cinco, empreendedores; 52 desses arranjos não são ligados a nenhum coletivo; 46

\footnotetext{
${ }^{27}$ Fizemos parte da delegação que representou o Brasil nesse Fórum, na Tunísia.

${ }^{28}$ Dados da Anatel, disponíveis em http://www.anatel.gov.br/dados/dessaque-1/283-brasil-tem-236-2-milhoesde-linhas-moveis-em-janeiro-de-2018

29 A tese de doutorado de Cláudia Nonato analisa esse movimento. Disponível em https://www.teses.usp.br/teses/disponiveis/27/27152/tde-26062015- 
identificaram-se como jornalista; 38 dizem ser uma iniciativa jornalística e 32 responderam que não são jornalísticos; embora 54 haja marcas da práxis jornalística.

Com esse quadro sobre quem são as pessoas, como fizeram, com quais pautas e como se organizam, podemos observar o conceito de alternativo através de chaves diferentes que revelam estar sob o mesmo guarda-chuva da comunicação alternativa.

\section{O conceito de comunicação alternativa}

Dentre os exemplos históricos que utilizamos é possível dizer que todos os veículos podem ser chamados de mídia alternativa? Qual é a definição conceitual que pode delimitar ou não, e que consiga gerar unidade de análise mínima entre os pesquisadores do tema?

O ponto de convergência entre investigadores é justamente não ter consenso conceitual, o que torna, ao mesmo tempo, desafiador explorar essa tensão e trabalhoso para uma visão com coesão para ser continuamente pesquisada a partir de pontos comuns. Para isso, vamos nos apoiar em alguns autores para entender o fenômeno da mídia alternativa.

É também ponto de confluência a questão que se é alternativo é uma opção a alguma coisa, a algo ou alguém. Mas a quê? Quais são as categorias determinantes capazes de chegar a uma generalização?

Como vimos, o fator externo, o todo, ou seja, os contextos políticos e sociais estão sempre em movimento e sempre interagem no interior da mídia alternativa, ao mesmo tempo que esse tipo de comunicação também influi em maior ou menor grau no ambiente geral, provocando os tensionamentos necessários em torno de determinadas causas. A comunicação alternativa tem suas propriedades e ligações que lhe são próprias e constituem a sua singularidade.

Essa qualidade específica é articulada organicamente com o geral, interpenetrando-se, podendo ser separada somente em um movimento de abstração para explicitação como conceito.

O movimento dialético do conceito advém da estrutura ao mesmo tempo em que o reflexo dessa intervenção da matéria multifacetada em mediações retorna ao próprio interior da mídia alternativa, proporcionando o movimento de desenvolvimento. 
transformações que conduzem à passagem do inferior ao superior, do simples ao complexo, isto é, o desenvolvimento. (CHEPTULIN, 2004, p.167)

Peruzzo (2004) defende que o conceito alternativo ganha diferentes significados com o passar do tempo e para classificar as mudanças divide em duas classificações: 1) comunicação popular, alternativa e comunitária; 2) imprensa alternativa.

Estão sob a comunicação popular, alternativa e comunitária (CPAC), segundo a autora, as iniciativas populares, orgânicas aos movimentos sociais, educativas, comunitárias que são vinculadas aos movimentos sociais, segmentos populacionais e comunidades que têm em comum o projeto de mudança social e a luta por direitos de cidadania.

Quando Peruzzo fala de imprensa alternativa, refere-se ao jornalismo praticado com certo distanciamento dessas organizações. Embora haja diálogo constante entre o movimento social, popular e comunitário, ao mesmo tempo em que há a preocupação com a qualidade jornalística das publicações. "Desse modo, o que caracteriza esse tipo de jornal como alternativo é o fato de representar uma opção como fonte de informação, pela cobertura de temas ausentes da grande mídia e pela abordagem crítica dos conteúdos que oferece.” (PERUZZO, 2009, p. 56)

Para Fiorucci (2011), os meios de comunicação alternativa precisam estar necessariamente vinculados à esquerda e, consequentemente, defender as bandeiras da esquerda. Portanto, o autor defende a mídia alternativa como tradução de mídia de engajamento, tendo a crítica social e política como eixos fundamentais.

Outro autor que se aproxima da definição de Fiorucci é John D. H. Downing (2002), que sustenta que "[...] a mídia radical alternativa constitui a forma mais atuante da audiência ativa e expressa as tendências de oposição, abertas e veladas, nas culturas populares." Para o autor, a missão da mídia radical, como usualmente denomina a mídia alternativa, é:

[...] a mídia radical tem a missão não apenas de fornecer ao público os fatos que lhe são negados, mas também de pesquisar novas formas de desenvolver uma perspectiva de questionamento do processo hegemônico e fortalecer o sentimento de confiança do público em seu poder de engendrar mudanças construtivas. (2002, p. 50)

Para esses dois especialistas no tema, a categoria determinante para definição de alternativo é o conteúdo, sendo assim, deve "[...] posicionar o meio estritamente do lado da esquerda e da crítica ao modelo capitalista.” (FIORUCCI, 2011, p. 93) Da mesma forma, para Downing (idem), a mídia alternativa precisa “[...] expressar uma visão alternativa às políticas, prioridades e perspectivas hegemônicas[...]" para estar enquadrada no conceito. 
Voltando à Peruzzo (2009), é a práxis social que determina as características de comunicação popular, comunitária e alternativa no conjunto do processo; não o veículo utilizado, linguagem, propriedade, formato, de maneira isolada, mas como se dá o processo e a relação com a comunidade. Porém, a autora não coloca o critério de participação entre os determinantes do alternativo, sendo que o morador pode participar através de uma carta a um programa, ter voz ativa na programação sem participar diretamente na gestão do veículo.

Neumann (1989, p. 26) coloca a questão da participação como categoria chave para definição de alternativo e, principalmente à mídia comunitária, tendo os membros do grupo como o ator principal, de forma que seja "[...] feita pelo grupo e não para o grupo."

Com clara influência de Paulo Freire, Kaplún $(1982$, p. 7) defende que a comunicação popular democrática deve “[...] estar a serviço de um processo educativo libertador e transformador, vinculado estreitamente à organização popular e ser uma autêntica comunicação, com metas de diálogo e participação."

Assim como Peruzzo, o autor também divide e classifica de maneira diferente os tipos de comunicação, sendo que comunicação alternativa são os meios de comunicação com direcionamento contra-hegemônico; comunicação popular a que se coloca em defesa do interesse das classes populares; e comunicação participativa como aquela em que a participação permeia todas as etapas dos processos comunicativos.

\section{O alternativo como um conceito "sede"}

Néstor García Canclini (2016), ao falar do significado de tradução como "dizer de outra forma", iguala a ação ao uso de metáforas e conceitos e sustenta que esse último viaja entre disciplinas, épocas e comunidades acadêmicas dispersas.

[...] os conceitos se parecem com as metáforas na medida em que não condensam de um único modo o sentido, de uma vez por todas, porque são pontos flexíveis de coincidência, "sedes de debates", estratégias providenciais para conversar, colaborar ou brigar, com certa coerência. (CANCLINI, 2016, p. 68)

Utilizaremos o conceito "sede de debates" como forma de deixar sob o alternativo os tipos variados de comunicação que fazem parte do mesmo conceito. Isso não significa que não haverá critérios para esses processos comunicativos "entrarem na sede", mas sim, como forma de deixar mais evidente as categorias determinantes para definição conceitual.

Como vimos, alguns autores estabelecem o conteúdo, a participação e os objetivos do arranjo como chave principal para delimitar o conceito de alternativo'. 
Embora Peruzzo (2009) faça a distinção entre comunicação popular, alternativa e comunitária e imprensa alternativa, nos aproximamos da autora ao colocar lado a lado os três tipos de comunicação como processos semelhantes, pois nos parece um todo uno com partes diferenciadas, como explicitaremos a seguir.

Diferentemente dos autores que acabamos de citar, a nossa chave para análise de alternativo são as relações de produção. O processo produtivo é a categoria de análise que confere força ao alternativo e influencia tanto a produção quanto a práxis social. Nesse sentido, nos aproximamos de Atton (2002), que coloca a posição do trabalho no que diz respeito às relações de produção e ao formar “[...] uma relação dialética entre os atores e estruturas envolvidos no sistema de mídia, formando assim uma mídia crítica." (SILVA, 2017)

Se as relações de produção, logo de partida, identificam-se pela reprodução mecânica, como na relação de um veículo comercial, a totalidade do processo será marcada por essas relações. O fato de serem caracterizadas pela horizontalidade ou mais permeabilidade das fontes e leitores faz com que haja mais discussão sobre as práticas jornalísticas.

Assim sendo, o conteúdo refletido das mediações, entre essas a do trabalho, pode ser resultado de inferências que dialogam culturalmente com as contradições existentes entre capital e trabalho.

Se o modo de produção é uma categoria determinante que influenciará o conteúdo e as formas de participação no processo comunicativo, as diferenças que separam os tipos de comunicação se dissolvem a ponto de conseguirmos identificar tanto a comunicação popular, a comunitária e a imprensa alternativa no mesmo guarda-chuva do alternativo.

A categoria modo de produção foi desenvolvida por Marx (1983) para qualificar a maneira de organização da sociedade na produção de suas necessidades materiais, relacionadas com o nível de desenvolvimento das forças produtivas e as relações de produção.

Para analisar o conceito alternativo é fundamental entendermos como os trabalhadores da comunicação estão produzindo, como utilizam a matéria que produzem e a maneira como as distribuem. O excerto de Marx (1993, p. 24) em Contribuição à crítica da economia política diz:

A conclusão geral a que cheguei e que, uma vez adquirida, serviu de fio condutor dos meus estudos, pode formular-se resumidamente assim: na produção social da sua existência, os homens estabelecem relações determinadas, necessárias, independentes de sua vontade, relações de produção que correspondem a um determinado grau de desenvolvimento das forças produtivas materiais. 
Portanto, a utilização do modo de produção como "centro do nó" de alternativo nos possibilita entender de maneira coesa o conceito e a principal distinção entre as mídias passa a ficar mais clara até em contraposição à mídia comercial, visto que as pautas populares e comunitárias não são veiculadas nesse tipo de mídia, se não estiverem vinculadas à lógica da informação como mercadoria, entretenimento ou forma de dominação.

Além disso, o sentido de comunitário tem constantemente sido limitado às possibilidades de formação de identidade local, vínculo afetivo, proximidade territorial sem haver relação entre o particular - características da comunidade - e o geral - elementos constitutivos da formação social, econômica e política. Outra questão objetiva é que a comunicação comunitária tradicionalmente tem sido apropriada por pequenos empresários que se apoiam na venda de publicidade local, por igrejas ou por parlamentares, cujas práticas muito se distanciam da participação popular e da contraposição ao status quo.

Atton (2002) e Duncombe (1997 apud ATTON, com tradução nossa) destacam os processos produtivos das outras categorias: “[...]é a posição do trabalho no que diz respeito às relações de produção que dão o seu poder [...]." Fica mais evidente na seguinte conceituação de Atton:

A mídia alternativa pode ser entendida como um desafio radical às práticas profissionalizadas e institucionalizadas da grande mídia. A mídia alternativa privilegia um jornalismo intimamente ligado a noções de responsabilidade, substituindo uma ideologia de "objetividade" por uma defesa e práticas de oposição. Suas práticas enfatizam os relatos de testemunhas oculares em primeira pessoa pelos participantes; uma reformulação das abordagens populistas do tabloide, jornais para recuperar um estilo "popular radical" de reportagem; formas coletivas e antihierárquicas de organização que evitam a demarcação e a especialização - e que, de maneira importante, sugerem uma forma inclusiva e radical de jornalismo. (ATTON, 2003. p. 269, com tradução nossa).

Dessa forma, podemos nos aproximar novamente de Dênis de Moraes ao compreender a comunicação alternativa como um processo de "democratização substantiva da vida social":

Essa noção de comunicação alternativa é compreendida como processo a um só tempo comunicacional, político, engajado e participativo, processo que envolve indivíduos, grupos e coletivos afinados, de um lado com uma visão anticorporativa do trabalho jornalístico e, de outro, com uma ação cultural em favor da sociabilização da política e de uma democratização substantiva da vida social. (MORAES, 2008, p. 45)

O posicionamento de veículos alternativos se dá na arena da luta de classes, na sociedade civil com múltiplas inferências das relações de poder, das disputas entre forças sociais, cenário repleto de contradições.

Os veículos alternativos incluem-se assim na categoria dos aparelhos privados de hegemonia de Gramsci: atuam na sociedade civil como organismos coletivos de 
natureza voluntária, relativamente autônomos em face do Estado em sentido estrito e gerados pela moderna luta de classes. (COUTINHO, 2006b, p. 34)

Podemos inferir que comunicação alternativa mais do que um tipo de mídia ou imprensa, é o sentido da práxis na comunicação que reflete e constitui a luta dialética pela direção moral, ética e cultural da sociedade no sentido contrário ao estabelecido pelo capital. Dessa forma, não é o lucro o objetivo da mídia alternativa, assim como as relações em seu processo produtivo são estabelecidas conforme outra lógica daquela que se dá entre capital e trabalho.

Até aqui o nosso percurso foi o de compreender histórica e socialmente as atividades da comunicação alternativa no país. O fio condutor de nossa análise foram os principais choques entre as classes sociais, as informações de situações concretas onde estavam dadas essas experiências e os aspectos gerais de forma abstrata para separar os elementos particulares que constituem o conceito de comunicação alternativa. É importante ressaltar que a abstração e generalização são possíveis como recorte metodológico para que, através dos aspectos concretos, possa se chegar à subjetividade do fenômeno.

Através do olhar histórico aos processos e condições de produção de arranjos e coletivos podemos inferir essa categoria analítica como a estrutura do conceito, que sustenta a ideia de sede para ser amplo ao mesmo tempo que radical, do ponto de vista de raiz, radicalidade. A operacionalização do conceito é relacional já que é alternativo sempre a algo, alguma coisa. Alternativo à lógica da notícia como mercadoria, ao discurso, à organização produtiva, quanto às relações empregadas nas redações das grandes corporações de mídia.

Para compreender a comunicação alternativa de forma aprofundada é necessário ir além do paradigma funcionalista e, para tal objetivo, vamos nos apoiar na contribuição da teoria gramsciana aos Estudos Culturais.

\section{O conceito de hegemonia e a teoria dos Estudos Culturais}

Para alargar a conceituação de comunicação alternativa, aproximamos diferentes atividades que não são consideradas pertencentes aos aparelhos hegemônicos para, desse modo, agrupar sob o conceito distintas forças contra-hegemônicas de um mesmo bloco histórico em um processo vivo e permanente.

Essa aproximação só foi possível devido à abertura dada pelos Estudos Culturais, os 
quais propiciaram uma compreensão do fenômeno comunicacional cujo teor interrompe a visão behaviorista, do mecanismo direto de estímulo e resposta ao permitir compreender os meios de comunicação como meios de produção - em que as lógicas de produção, difusão e consumo são consideradas como uma força social e política.

Outro rompimento foi com a caracterização de público como uma massa de indivíduos atomizados e passivos. A consequência disso se deu através de processos variados de análises das formas que as mensagens são decodificadas por diferentes públicos de diferentes contextos políticos e sociais.

Isso porque teóricos dos Estudos Culturais, da Escola de Birmingham, basearam-se na teoria de Antônio Gramsci ${ }^{30}$ para as análises dos processos culturais e comunicacionais. Principalmente o conceito elaborado por ele sobre hegemonia e contra-hegemonia. ${ }^{31}$

Para Raymond Williams (1979), os meios de comunicação são compreendidos como meios de produção e são mobilizados para determinadas finalidades pelos setores hegemônicos porque auxiliam quanto à criação de outras experiências, relações sociais e na produção de outras relações culturais. Os meios de comunicação como meios de produção na atualidade, por exemplo, caracterizam um tipo de sociedade, cujo eixo central organizativo, o trabalho, transformou-se completamente.

O autor define o conceito de marxismo cultural e em seu livro Marxismo e literatura expõe a cultura em sua materialidade e no campo simbólico. Outro tema central de sua obra é conceituação de hegemonia como um conjunto de práticas e expectativas relacionado à constituição da percepção individual e coletiva, sobre "nós mesmo e o mundo dentre significados, valores, vivências e práticas":

A hegemonia é então não apenas o nível articulado superior de "ideologia", nem
são as suas formas de controle apenas as vistas habitualmente como
"manipulação" ou "doutrinação". É todo um conjunto de práticas e expectativas,
sobre a totalidade da vida: nossos sentidos e distribuição de energia, nossa
percepção de nós mesmos e nosso mundo. É um sistema vivido de significados e
valores - constitutivo e constituidor - que, ao serem experimentados como
práticas, parecem confirmar-se reciprocamente. Constitui assim um senso da
realidade para a maioria das pessoas na sociedade, um senso de realidade

30 Antônio Gramsci (1891-1937) foi um ativista político, jornalista e intelectual italiano, um dos fundadores do Partido Comunista da Itália.

${ }^{31} \mathrm{O}$ italiano e membro do Partido Comunista da Itália compôs boa parte de sua obra enquanto estava preso entre 1927 e 1935, em pleno fascismo. Cadernos do Cárcere é a obra que contém a consolidação de seus principais conceitos, entre eles o de "hegemonia", que é o elemento de unidade entre os cadernos miscelâneos e os seis volumes dos Cadernos. 
absoluta, porque experimentada, e além da qual é muito difícil para a maioria dos membros da sociedade movimentar-se, na maioria das áreas de sua vida. Em outras palavras, é no sentido mais forte uma "cultura", mas uma cultura que tem também de ser considerada como o domínio e subordinação vividos de determinadas classes. (WILLIAMS, 1979, p. 112)

De acordo com Schulman (2000), os Estudos Culturais colocavam em xeque as pesquisas que "[...] viam os textos da mídia como suportes transparentes do significado [...]" e que os autores britânicos chamaram atenção para o "[...] potencial estruturador que cada meio - incluindo a linguagem - possui."

Enquanto McLuhan argumentava, em um sentido amplo e formalista, que "o meio é a mensagem", os Estudos Culturais britânicos examinavam, já no início dos anos 70, os sistemas de signo através dos quais os significados mediados pelos meios de comunicação de massa chegam ao público. Influenciado pelo estruturalismo europeu, o Centro publicou os trabalhos iniciais de Barthes e Eco em seus Working papers in Cultural Studies, incorporando, mais recentemente parte da teoria do Discurso de Foucault. (SCHULMAN, 2000, p. 182)

Outro questionamento de fundo realizado pelo Centro de Birmingham foi sobre a visão maniqueísta acerca da relação entre superestrutura e infraestrutura em que as bases comunicativas estão intrinsicamente ligadas à superestrutura e sobre as formas com que as alterações dos meios de produção e de comunicação afetam as relações de classe.

Essa visão tem clara influência de Gramsci e na concepção de hegemonia como “[...] a capacidade de um grupo social de assumir a direção intelectual e moral sobre a sociedade, sua capacidade de construir em torno de seu projeto um novo sistema de alianças [...]”, conforme Armand e Michéle Mattelart (2014), e como um "local de luta" (SCHULMAN, 2000).

O conceito de hegemonia ajudou os estudiosos do Centro a sair do impasse que o marxismo estruturalista de Althusser havia criado, fazendo com que certas concepções de agência parecessem fúteis diante do que era teorizado como posicionamento ideológico inevitável do indivíduo pelo aparato do Estado e suas agências, tais como a escola e a família. (SCHULMAN, 2000, p. 216)

Deriva do significado de hegemonia a concepção de que a ideologia e, consequentemente, as práticas culturais e a produção dos meios de comunicação são componentes de uma arena de lutas contínuas e não pré-determinadas acerca da disputa de significados e sentidos.

Para entender como essa luta acontecia no seio da sociedade, os Estudos Culturais utilizaram metodologias diversas como etnografia, estudos da mídia, linguagem, observação participante em que o objetivo em termos mais amplos era investigar a experiência humana, práticas institucionais e a sociedade contemporânea. 
Gramsci também era um cientista que buscava compreender a sociedade de seu tempo e destacava a comunicação na disputa dos sentidos circulantes na realidade social. Antes de ter a sua sentença de morte assinada por Benito Mussolini e o regime fascista, Gramsci foi ativo militante e chegou a fundar, em 1919, o jornal L'Ordine Nuovo, com Palmiro Togliatti, Angelo Tasca e Umberto Terracini. Mais tarde, o jornal tornou-se um instrumento de disputa do cenário político italiano. Esse processo revela a concepção do papel da comunicação e do jornalismo para Gramsci e o desenvolvimento de sua teoria.

A partir do marxismo e do materialismo dialético, Gramsci buscou desenvolver a teoria de Lênin, com o qual teve ainda mais contato em sua viagem à então União Soviética. O termo "hegemonia" consta pela primeira vez em escritos do líder russo ao travar a disputa do início do movimento revolucionário com os mencheviques, tendência organizada por Leon Trotsky.

Lênin escreveu em 1905:

Segundo o ponto de vista proletário, a hegemonia pertence a quem se bate com maior energia, a quem se aproveita de toda ocasião para golpear o inimigo; pertence àquele cujas palavras correspondem tais fatos e que, portanto, é o líder ideológico da democracia, criticando the qualquer inconsequência. (LÊNIN apud GRUPI, p. 11)

O conceito de hegemonia é o elemento confluente entre o pensamento de Gramsci e Lênin. É preciso notar que, embora muitos pensadores e teóricos se debrucem sobre o legado científico do autor de Materialismo e empiriocriticismo, ${ }^{32}$ ainda na produção acadêmica brasileira existe uma lacuna e omissão de sua produção. Nossa suspeita é de que a ausência de estudos que tratam, discutem e problematizem essa herança se dá pela disputa política e ideológica dentro do próprio campo acadêmico, relacionada com uma luta maior acerca dos rumos da sociedade.

A compreensão de Gramsci e Lênin sobre hegemonia, embora próximas, são diferentes. Para o primeiro, diz respeito à capacidade dirigente e direção; para Lênin, é a função dirigente explícita em um processo de rupturas e transformações profundas. ${ }^{33}$

Para Gramsci, a formação social é uma situação de “[...] sincronia ou assincronia entre o poder e as fontes de legitimação no centro da sociedade civil [...]" local, onde há a guerra de

\footnotetext{
32 Título do livro de Lênin que trata sobre os aspectos filosóficos, escrito em 1909, em meio à negação da dialética e do materialismo histórico após a derrota de 1905. Analisa historicamente o sentido e o conteúdo da luta entre as duas correntes fundamentais da filosofia: o materialismo e o idealismo.

33 Lênin utiliza a expressão "ditadura do proletariado" como instrumento da revolução do proletariado. Hegemonia estava articulada para ele como ferramenta em contexto revolucionário.
} 
posição e o cenário para que sejam exploradas contradições, elementos neutralizados visando que a "[...] classe operária exerça hegemonia sobre as demais classes não exploradoras, apresentando-se como uma alternativa ao poder.” (GRUPPI, 1978, p. 12)

Contudo, outras singularidades permeiam a visão entre os dois. A primeira é acerca do marxismo considerada como uma filosofia que não se justifica por si só, mas uma filosofia viva e dialética.

Assim como Lênin, Gramsci também “[...] considerava a análise da situação concreta a essência do marxismo." Devido à apreensão da análise concreta, o conceito de hegemonia é articulado com o quadro conceitual de Marx de formação social, cujo teor foi aperfeiçoado no prefácio à Contribuição à crítica da economia política, de 1859.

Entre "forma da sociedade "e "formação da sociedade", há uma diferença que deve ser sublinhada: "forma" é uma expressão que indica uma realidade estática, estabelecida, enquanto formação indica um processo, um desenvolvimento. Marx aperfeiçoa o próprio pensamento precisamente no sentido de indicar o processo e não o momento estático. (GRUPPI, 1978. p. 19)

A concepção de uma formação que não é dada, mas vai se desenvolvendo com o avanço das forças produtivas coloca a teoria gramsciana em oposição ao "marxismo vulgar" e ao determinismo econômico.

O conceito de estrutura e superestrutura são os eixos principais da ideia de hegemonia e tanto Lênin quanto Gramsci seguiram a operação metodológica feita por Marx de isolar e abstrair a estrutura para compreender e defini-la a ponto de entender como caracterizam a unidade orgânica da sociedade. Para Lênin:

Esse é o esqueleto do capital: tudo consiste, porém no fato de que Marx não se contenta com esse esqueleto; que ele não se limita apenas à teoria econômica no sentido habitual da palavra; que mesmo explicando a estrutura e a evolução de uma dada formação social exclusivamente por meio das relações de produção, ele também investiga sempre e por toda a parte as superestruturas correspondentes a essas relações de produção, revestindo o esqueleto com carne e sangue. (LÊNIN, 1978, p. 26)

Ao se colocar em lado oposto ao determinismo mecânico com a concepção, ancorada na base econômica e nas relações de produção, Gramsci compreendia a sociedade como um todo unitário e orgânico. Influenciado por Antonio Labriola, intelectual italiano que ressaltava o papel do homem contra o determinismo histórico e, segundo Gruppi (1978), não compreendia o indivíduo como uma "[...] marionete movida por fios por esse deus oculto, por essa base econômica que explicaria tudo." 
Essas categorias econômicas são elas próprias resultado de um processo e estão em processo, como tudo o mais, pois os homens se modificam quanto à capacidade e à arte de vencer, subjugar, transformar e usar as condições naturais; pois os homens mudam de ânimo e de atitudes, pela reação de seus instrumentos sobre eles próprios; pois os homens se modificam em suas respectivas relações de convivência e, por isso, dependem de diferentes maneiras uns dos outros. Trata-se, em suma, da história, e não do seu esqueleto. Trata-se da narração, e não da abstração; trata-se de expor e de esboçar o conjunto, e não apenas de dissolvê-lo e de analisá-lo. (LABRIOLA, 1956, p. 126)

O próprio conjunto dos conceitos teóricos gramscianos pode ser considerado como resposta ao que chamava de "marxismo vulgar", o qual já determinava o fim da história de forma decretada. Porém, sua teoria também foi uma resposta para superar a espontaneidade do movimento e direcionar a intervenção nas lutas populares como forma de orientá-la na arena política e alcançar objetivos para a conquista da hegemonia.

De maneira mecanicista, Louis Althusser (1985, p. 60), com o exemplo metafórico de um edifício, explica a função de infraestrutura e da superestrutura como se fossem dois elementos separados pelo espaço. Afirma Althusser:

Pode-se dizer que os andares da superestrutura não são determinantes em última instância, mas que são determinados pela eficácia da base; que se eles são a seu modo (ainda não definido) determinantes, apenas o são enquanto determinados pela base.

Com o argumento de que "[...] os andares de cima não poderiam se sustentar sem a base [...]”, Althusser impôs um distanciamento que, na obra de Gramsci, não existe, pois, ao invés de andares diferentes, a estrutura e a superestrutura formam um "[...] bloco histórico de forças sociais e políticas por meio da ideologia.” A estrutura é, de acordo com a visão materialista dialética, ela própria contraditória, visto que expressa a base social da sociedade. Assim como as ideologias, superestruturas são produtos da relação de produção e trocas, estão expressas na vida cotidiana.

A relação entre estrutura e superestrutura, a formação do bloco histórico e o papel dos intelectuais na disputa hegemônica é um processo permanente. A interpretação de que a disputa já está dada, fadada ao triunfo da classe-que-vive-do-trabalho ou à barbárie, é a influência do idealismo e de uma 'força supernatural ou interior' e para a qual a transformação da sociedade não deve conter a participação e iniciativa do homem. Karl Marx aponta em 18 Brumário e Luís Bonaparte:

Os homens fazem sua própria história, mas não a fazem como querem, não a fazem sob circunstâncias de suas escolhas e sim sob aquelas com que se defrontam diretamente, ligadas e transmitidas pelo passado. A tradição de todas as gerações mortas oprime como um pesadelo o cérebro dos vivos. E justamente quando parecem empenhados em revolucionar-se a si e às coisas, em criar algo que jamais 
existiu, precisamente nesses períodos de crise revolucionária, os homens conjuram ansiosamente em seu auxílio os espíritos do passado, tomando-lhes emprestado os nomes, os gritos de guerra e as roupagens, a fim de apresentar a nova cena da história do mundo nesse disfarce tradicional e nessa linguagem emprestada. (MARX, 1968, p.15)

Outro ponto relevante na construção do conceito sobre hegemonia é que, através de um arco de alianças, os objetivos necessitam ser amplamente democráticos.

A formação do Conselho de Fábrica, órgão de base que Gramsci defendeu de forma veemente, evidencia essa concepção de amplitude. Para Gramsci, o conselho operário deveria ser formado não somente pelos trabalhadores que tinham relações associativas com o sindicato, mas um órgão unitário e representativo dos operários, empregados e técnicos.

A função do jornal L'Ordine Nuovo deveria estar a serviço dessa política. Enquanto Angelo Tasca defendia o jornal como um centro de divulgação cultural e voltado para a construção de uma corrente de esquerda entre os socialistas, Gramsci julgava que o jornal deveria ter como público alvo os trabalhadores dos Conselhos de Fábricas para plasmar entre eles o que era a produção capitalista, qual a função do conjunto dos trabalhadores nessa produção e, consequentemente, ter consciência histórica de seu papel e consciência de classe com teoria e prática social.

O objetivo de Gramsci é, a partir do movimento já existente, da realidade concreta, tornar o L' Ordine Nuovo um instrumento de orientação aos trabalhadores para elevar o nível da consciência a partir da experiência e o próprio percurso de luta dos operários.

A construção da hegemonia está, assim, ancorada na necessidade de compreender os problemas reais das "classes subalternas", além do apontamento das leis gerais que sustentam o capitalismo e, a partir da identificação dessa situação concreta, a formação de alianças de forças sociais que podem atuar de forma conjunta no "processo revolucionário"”.

Por isso, Gramsci defendeu que o papel do jornal L' Ordine Nuovo deveria estar articulado com a liberdade de consciência da classe trabalhadora. Esse objetivo não é deslocado do atual intuito da mídia alternativa que se coloca em posição oposta aos dos grandes grupos de mídia do Brasil.

\section{Amarrando os nós}

Nos principais embates sociais, os grupos de comunicação, tanto os que podemos 
chamar hoje de corporações de comunicação, antes um negócio de família que se transformou em empresa com a evolução do desenvolvimento das forças produtivas nacionais, quanto os grupos de comunicação alternativa foram forjados na busca pela intervenção em cada caso específico. Portanto, é necessário que a análise ocorra articulada com o momento histórico em que estavam inseridos e atuantes na difusão de percepções particulares da vida em sociedade, com alcance massivo, capacidade de persuasão e inferência na formação de sentidos e imaginários coletivos.

Isso posto, os meios de comunicação são, de acordo com Gramsci (2002) e Moraes (2008), agentes fundamentais que carregam a ideologia de forma material e objetivam angariar e sedimentar apoio na sociedade civil, seja para manter a dominação de seu grupo ou para explorar as contradições entre as classes, sendo que aqueles que visam à manutenção de bloco estão articulados nas mais múltiplas dimensões, entre elas, a coercitiva do Estado.

Consequentemente, a formulação de Gramsci de "bloco histórico" é essencial para apreender o lugar e a função da comunicação como aparelhos privados de hegemonia na sociedade compreendida como totalidade. Tanto os meios alternativos quanto os monopólios de comunicação estão inseridos numa unidade de forças sociais e políticas distintas e a concepção de mundo construída por cada qual forma os liames que agregam as diferentes forças e atuam em todos os níveis da sociedade ao buscar a direção ética, moral, política e ideológica no seio da sociedade civil.

É nessa disputa pela direção moral, ética, política e ideológica que são fundamentais as forças contra-hegemônicas para tensionar as contradições entre as forças do bloco histórico. Para também denunciar e ultrapassar as condições em que vivem as classes subalternas, assim como aprofundar o conhecimento da realidade para transformá-la, tendo como atribuição sobrepujar o determinismo e o conformismo que se colocam como táticas para as quais os meios de comunicação têm papel preponderante na propagação. Esse processo contra-hegemônico é gradual e permanente e precisa agir para transformar as relações sociais de poder.

Nesse sentido, é elementar compreender que entre comunicação alternativa e a mídia monopolizada há uma correlação, uma unidade dialética em que a própria definição entre si é vinculada. Isso porque as tendências opostas em cada bloco de forças estão permanentemente em estado de luta ao existirem juntos em uma ligação constante que se interpenetra e pressupõe uma à outra, supõe-se um relacionamento de aspectos recíprocos que não podem 
ocorrer fora da relação entre si, caracterizando no mesmo processo certo grau de unidade e oposição dos contrários.

Consequentemente, podemos inferir que toda hegemonia tem em si o princípio da contra-hegemonia e vice-versa. Podemos exemplificar a contribuição das corporações de mídia quanto à formulação do conceito de nação a partir da contribuição de jornalistas e intelectuais que atuavam na imprensa após a independência do Brasil e o subsídio dos jornais impressos para desenvolvimento cultural do país, aporte que inexiste ou é raro hoje nesse tipo de mídia.

Ao mesmo tempo há miríades de experiências de comunicação alternativa que, ao invés de se colocarem como contra-hegemônicas, não assimilam o seu poder e capacidade de explorar as contradições e fazer com que as classes subalternas possam extrapolar os seus anseios particulares e interesses imediatos, colocando-se como força capaz de dirigir ética e politicamente os rumos da sociedade. Não cabe ao papel do pesquisador julgar as necessidades emergenciais desses meios, mas vale apontar que, até pela sua força e participação dentro do Estado, as forças hegemônicas atuam para reproduzir e cooptar experiências que fazem parte do quadro da comunicação alternativa.

Entre a unidade e luta dos contrários de forças de comunicação, a luta pela hegemonia é também o embate pela apropriação dos meios de produção material e imaterial. É esse fator que confere à classe dominante o controle das condições objetivas e subjetivas para impor a sua hegemonia sobre a consciência social coletiva, influindo no seio da sociedade civil e dentro do Estado, utilizando-o como instrumento para a sua manutenção, ao reunir as vantagens quanto ao poder material, espiritual e político- hegemônico.

Portanto, operacionalizar a definição conceitual de comunicação alternativa e considerar o processo produtivo e, consequentemente, a posse dos meios de produção, para o processo de vigilância epistemológica da pesquisa, significa compreender como os interesses de classe agem para limitar as formas de consciência quanto à linguagem e à função da produção e circulação social do conhecimento.

Dessa forma, ao definir o processo e as condições de produção da comunicação alternativa, conseguimos aproximar no mesmo guarda-chuva o Correio Braziliense, $\mathrm{O}$ Homem de Cor, o jornalismo anarco-sindicalista, as práticas comunicacionais das CEBs, a imprensa de resistência, a imprensa comunitária, o movimento de blogueiros, ativistas 
digitais, midialivristas, o hackerativismo, os coletivos que defendem o jornalismo como função social, entre outras atividades de comunicação.

Atualmente, com a facilidade advinda das tecnologias de informação e comunicação, a posse do meio de produção é mais facilitada do que em períodos anteriores à rede mundial de computadores. Mas antes desse momento, a liberdade de imprimir, como apontada na discussão de John Milton (apud LIMA, 2010), era alvo de disputa e estava no centro das atividades da comunicação alternativa.

A utilização das condições da produção desse tipo de mídia também acarreta o reposicionamento do alternativo em outros momentos históricos.

Não é à toa que a principal referência nos estudos sobre a imprensa alternativa seja o autor de Jornalistas e revolucionários: nos tempos da imprensa alternativa, Bernardo Kucinski. A principal tendência nas análises é o surgimento da mídia alternativa ter se dado durante a resistência ao período de ditadura militar brasileira. Essa elaboração afasta outras experiências, mesmo aquelas que são fruto da defesa da democracia em outros momentos históricos, haja vista que a própria democracia nacional se constitui entre os embates das classes sociais, considerando a linha de análise que destaca a história desse confronto.

Portanto, podemos considerar que, embora tenha se dado de maneira mais clara em um cenário de polarização política, a comunicação alternativa ou a "mídia nanica", como é conceituada por alguns autores, não nasceu no período da ditadura militar, sendo eminente no processo permanente de disputa na arena da sociedade civil em toda a história do Brasil. 


\section{Capítulo III}

Os arranjos alternativos de comunicação do Ateliê do Bixiga 
No curso da pesquisa, os arranjos de comunicação saíram do Ateliê do Bixiga por diferentes motivos. O primeiro a sair foram os Jornalistas Livres porque não utilizavam a sala no cotidiano, sendo prescindível uma sede fixa. O segundo foi o Opera Mundi, porque era necessária uma sala mais ampla para montagem de um estúdio e com internet mais forte. A estrutura física e a organização do Ateliê também foram as razões para o Outras Palavras mudar de endereço e, a falta de segurança política, advinda da eleição de Jair Bolsonaro, motivou a saída da Agência Pressenza do espaço compartilhado de trabalho.

Mesmo assim, decidimos continuar o estudo de casos múltiplos para investigar a possibilidade de contribuir com a formulação de políticas públicas a partir de espaços ociosos pertencentes ao Estado, que podem servir para abrigar iniciativas de trabalho como estímulo para a pluralidade e a diversidade de produção de informação, principalmente nos chamados "desertos informativos" 34 , locais em que não são ofertados nenhum tipo de informação sobre a política, a comunidade ou outros assuntos de interesse público.

A seguir vamos descrever cada arranjo econômico alternativo analisado - Agência Pressenza, Jornalistas Livres, Opera Mundi e Outras Palavras - e demonstrar como funcionam, sua composição, assuntos veiculados e as suas respectivas rotinas produtivas.

\section{Agência Pressenza}

A criação dos arranjos analisados nesta dissertação e outras iniciativas históricas que estão sob o guarda-chuva da comunicação alternativa está relacionada às estruturas e superestruturas, às questões macrossociais e à disputa dentro da arena social.

Conforme essa perspectiva, a fundação da Agência Pressenza se deu por meio da cobertura da Primeira Marcha Mundial Pela Paz, que percorreu distintos lugares do mundo em 90 dias, saindo da Nova Zelândia e finalizando a manifestação na Argentina e, consequentemente, tendo acumulado grande banco de conteúdo e imagens geradas por ativistas que acompanharam o trajeto.

Para não dispersar a organização preparada antes e durante a marcha, foi fundada em Milão, pelas jornalistas Piá Figueiroa, do Chile, e Nelsy Lizarazo, do Equador, no final de

\footnotetext{
${ }^{34}$ Conceito explicitado no Atlas da Notícia, que mostra que quase 35\% da população nacional não tem acesso à fonte de informações. Ver mais em https://www.atlas.jor.br/docs/Atlas_da_Not\%C3\%ADcia-jornais_onlineresultados.pdf
} 
2009, como uma agência especializada em notícias de paz e não violência como foco principal, embora tenha outras questões como direitos humanos e cultura.

De acordo com o site internacional:

Pressenza é um espaço aberto à expressão da base social. Privilegia uma óptica humanista universalista e promove ativamente convênios de colaboração e alianças com outras agências, bem como vínculos de reciprocidade com portais, plataformas, meios informativos e de comunicação, de coletividades e culturas específicas. Pressenza participa de uma ampla rede de novos meios que conseguem difusão mundial de suas propostas locais ao mesmo tempo em que nutrem suas informações com o material que provê a agência. (Site Pressenza, 2018)

Feita por profissionais da comunicação em redações descentralizadas como colunistas, repórteres, fotógrafos, gráficos, cineastas e tradutores que contribuem através de doação de seu trabalho profissional, o arranjo internacional emite sem custo boletins diários de notícias em inglês, italiano, espanhol, francês, português, alemão, grego e catalão.

Os fundadores da seção brasileira acompanharam o percurso da Marcha na América Latina e assumiram a organização dividida em duas redações, no Rio de Janeiro e a de São Paulo, pesquisada por nós.

Como a marcha tinha voluntários de uns vinte países, ela já surge em vários países ao mesmo tempo, só que em alguns lugares ela já tinha mais força por ter mais gente, por exemplo, no Chile, no Equador, na Argentina, aqui no Brasil já começou com um grupo de seis, sete pessoas. Então, já começou com várias redações simultâneas, é muito curioso o processo, porque nem a gente esperava, não foi uma coisa planejada. Foi meio na dinâmica das coisas que a gente estava organizando. Esse processo da agência, desde o começo foi todo mundo voluntário, era muito em função, sei lá, um pouco do que é hoje a Mídia Ninja, era para cobrir mais manifestações de paz, de não violência, então, era uma coisa muito de nicho, assim, e não foi muito planejado. (Guilherme de Almeida, 2018)

Atualmente, a Pressenza está presente em vinte e quatro países e é reconhecida como Agência Internacional de Notícias pelo governo do Equador, desde 2014. ${ }^{35}$

\footnotetext{
${ }^{35}$ Acordo número 37 do 4 de junho do 2014 da Secretaria Nacional de Comunicação do Equador.
} 


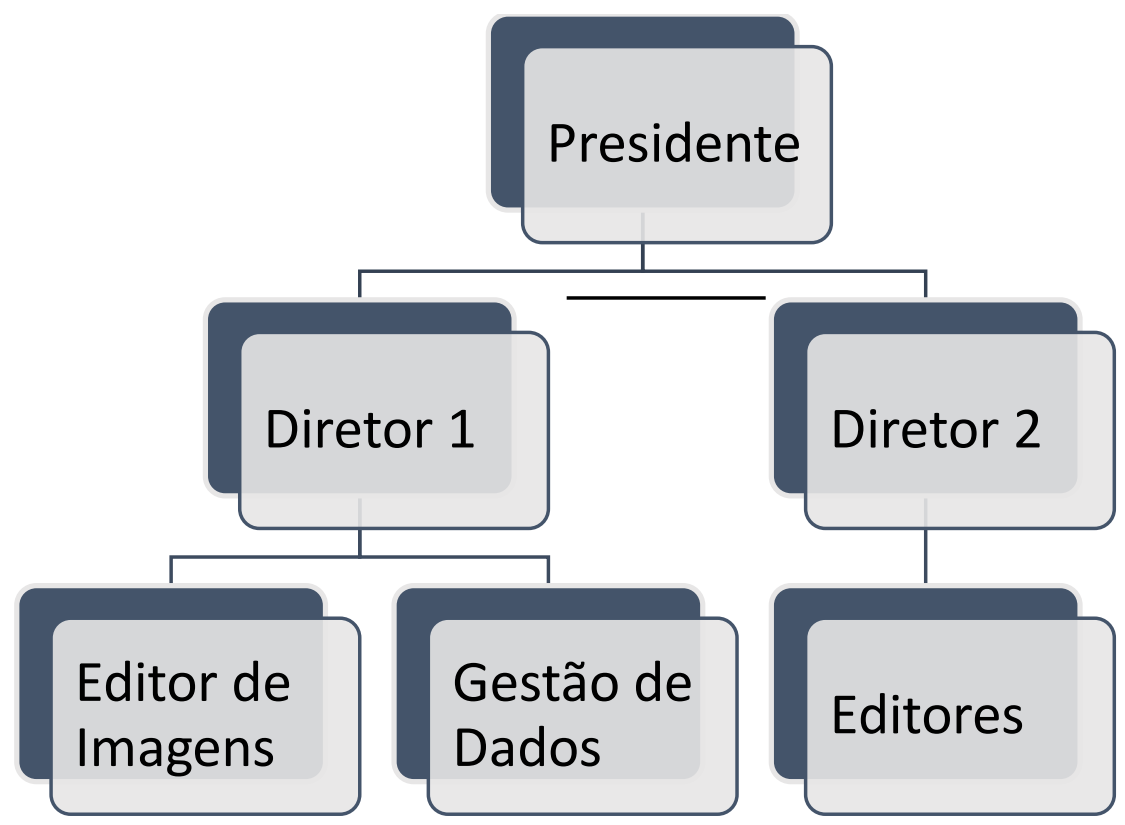

Figura 5 - Organograma da Agência Pressenza Internacional de Notícias - Fonte: A autora (2018)

Organizada com presidente, diretores e editores nacionais, a sua produção passa por uma redação virtual (espaço que se dá através da conectividade e que veremos detalhadamente no Capítulo IV), onde há a discussão sobre a política editorial, a pauta jornalística e as relações e posicionamentos políticos da Agência. Por exemplo, já foram temas com mais tensão as eleições do Chile, Bolívia, a cobertura sobre a morte de Fidel Castro e o conflito na Venezuela. A busca é por consenso e "decisões vinculantes" como podemos observar na descrição feita por Guilherme de Almeida, entrevistado nesta pesquisa.

Há um alinhamento, assim, decisões coletivas. A gente tenta organizar por consenso e decisões vinculantes, então, uma vez que chegue ao consenso vincula para todo mundo, se não chega a um consenso, a gente discute mais, mesmo que demore, que respeite as minorias dentro do coletivo, das redações, porque tem posições, às vezes, divergentes. A gente brinca, lá na Venezuela tinha dois da Pressenza, um era a favor e outro era contra. Aí o que você faz? (Guilherme de Almeida, 2018)

Quando não há unidade suficiente o assunto é abordado na Agência com a assinatura do jornalista para deixar evidente que não é posição do arranjo ao mesmo tempo que esse tipo de produção é visto como estímulo para discussão e alcance de consenso.

As decisões encaminhadas transbordam o jornalismo, sendo também resoluções de apoio a partidos e lideranças humanistas ou apoio crítico a algumas questões e candidatos em momentos eleitorais, revelando assim outra dimensão do arranjo em nível internacional e local que é busca de influenciar diretamente no poder institucional. No Brasil, a agência 
apoiou candidatos a deputados estaduais e federais com mandatos coletivos, segundo Guilherme de Almeida, baseada na experiência da Frente Ampla do Chile.

Cada redação tem suas reuniões de pautas locais e uma vez por mês mais ou menos a gente faz chats entre redações. Às vezes, da América Latina, às vezes do mundo todo, e uma vez por ano tem uma espécie de encontro anual de planejamento e tal. Esse ano foi em Madri, eu fui lá e a gente reuniu várias redações e o próximo vai ser em maio do ano que vem, no Chile. Quem não pode ir presencialmente se conecta, antes a gente usava um programa, que eu não lembro, agora tem o Zoom, que é bem melhor do que o Skype, no sentido de permitir vinte conexões simultâneas, bemestáveis, então, tem alguns programas que funcionam bem melhor. (Guilherme de Almeida, 2018)

A Agência Pressenza brasileira trabalha a partir da redação física, sendo as reuniões on-line apenas em casos emergenciais. De acordo com Guilherme de Almeida, como a maior parte da produção é feita em audiovisual, não é necessário um espaço on-line com discussão permanente. Conforme o entrevistado, “[...] a linguagem audiovisual exige outro tipo de trabalho como estudar um roteiro por oito, 12 horas; fazer produção, enfim, é diferente da produção de hardnews."

No entanto, são utilizadas outras formas de organização com o uso das tecnologias, como a utilização do Trello $^{36}$. Embora disponha de espaço para inserir discussão e comentários, o aplicativo tinha função de controle do trabalho para os profissionais do arranjo, já que o programa apontava o término de uma ação, assim como o início de nova atribuição.

As reuniões de pauta são abertas e há o esforço de envolver estudantes nos planos de coberturas do arranjo com a campanha Seja Voluntário, que é divulgada através de cartazes nas universidades e escolas. A adesão de voluntários é tema da própria reunião. "A gente sempre traz gente da Cásper, USP e Mackenzie. É importante trazer a galera da periferia que estuda nas escolas técnicas também porque faz toda a diferença no processo", interveio uma das jornalistas do arranjo (informação verbal) ${ }^{37}$.

\footnotetext{
${ }^{36}$ Aplicativo de gerenciamento on-line que pode ser utilizado por uma ou mais pessoas.

${ }^{37}$ Informação coletada junto a Guilherme de Almeida, na reunião de pauta do arranjo no dia 28 de junho de 2018.
} 


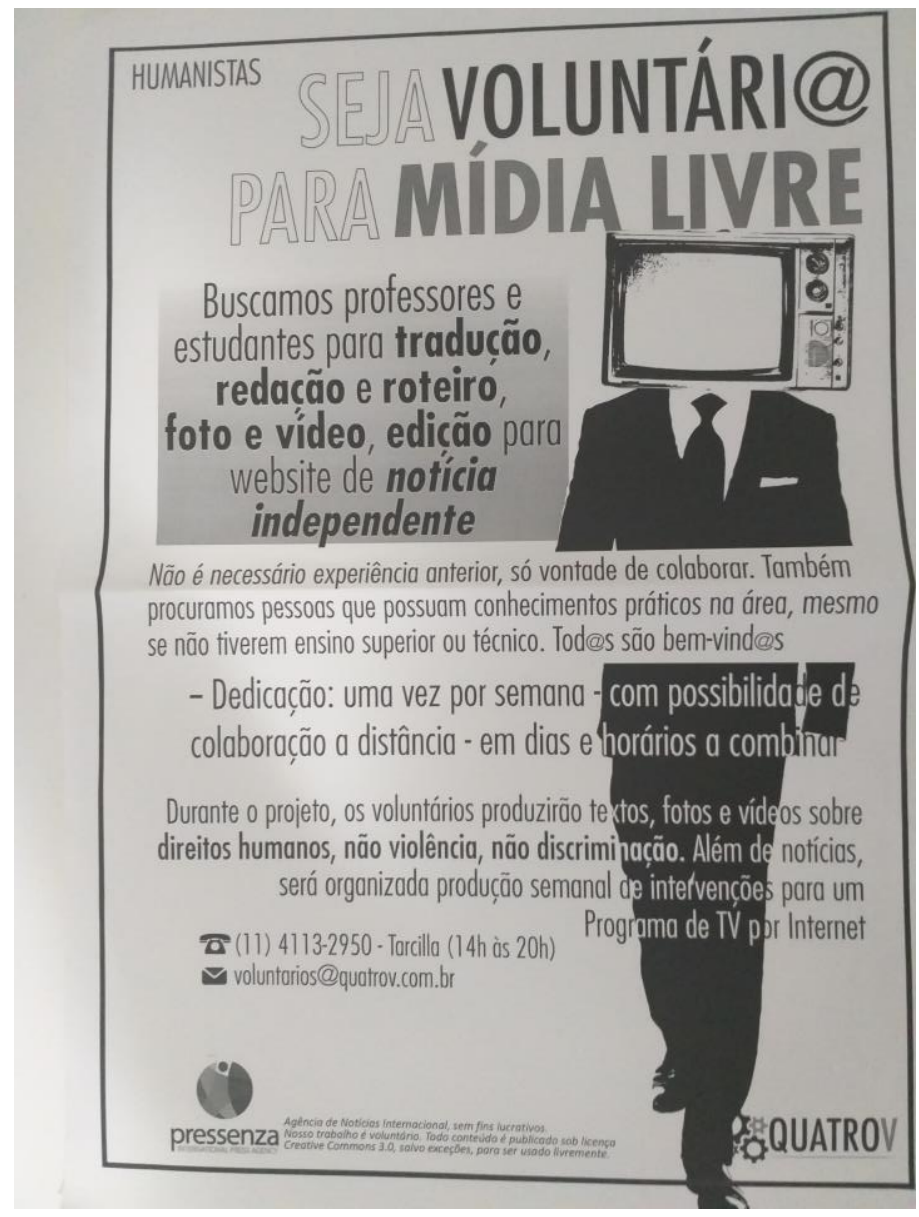

Figura 6 - Cartaz da Agência Pressenza que é colocado em escolas técnicas e universidades - Crédito: A autora

A discussão sobre a pauta é iniciada sempre com um informe do coordenador-geral da redação, com a contextualização dos assuntos que julga relevantes e dados sobre andamentos de outros projetos e, além de planejar o trabalho, tem como objetivo nivelar entre os membros as informações de ações e produção no período. Também cabe aos presentes o debate sobre as contas do arranjo, o andamento de projetos e a busca por outros que contribuam "[...] pelo menos para pagar o aluguel [...]" (Guilherme de Almeida, 2018) No ponto de discussão sobre a cobertura, os jornalistas já saem com responsabilidades para toda semana. Outros ajustes são feitos na própria redação.

Durante a observação em uma dessas reuniões, pudemos perceber que alguns assuntos eram direcionados para um segundo arranjo chamado 4V. "Precisamos cuidar mais do site da Quatro V, porque está parecendo mais um coletivo do que um site”, (informação verbal) ${ }^{38}$ introduziu na pauta Guilherme de Almeida.

\footnotetext{
${ }^{38}$ Informação coletada junto a Guilherme de Almeida na observação da reunião de pauta do dia 28 de junho de 2018.
} 
Junto com essa preocupação, surgiu a discussão de Pressenza e 4V iniciarem uma nova linha editorial sugerida pela equipe de Malala Yousafzai $^{39}$ em visita ao Brasil e ao arranjo. A luta antifundamentalista, articulada com os temas de comportamento e estilo de vida antes de serem incorporados, é debatida no movimento humanista, o qual é ligado ao veículo jornalístico.

O tema, de acordo com Guilherme Almeida, é um dos eixos do Fundo Malala que, entre os seus objetivos, está à busca de entidades e ativistas de educação com consolidado histórico de trabalho, mas que não têm apoio para as suas ações e a oferta de suporte financeiro e treinamentos, além de colocar em contato essas experiências dispersas pelo mundo.

Durante a visita de Yousafzai, em julho de 2018, coincidentemente no dia de nossa observação do trabalho, o arranjo foi selecionado pelo Fundo com outras organizações não governamentais, como Ação Educativa ${ }^{40}$, para receber recursos e viabilizar o Manual em defesa do docente contra o Escola sem Partido ${ }^{41}$ que, naquele momento, era tema de uma campanha de arrecadação pelo $4 \mathrm{~V}$.

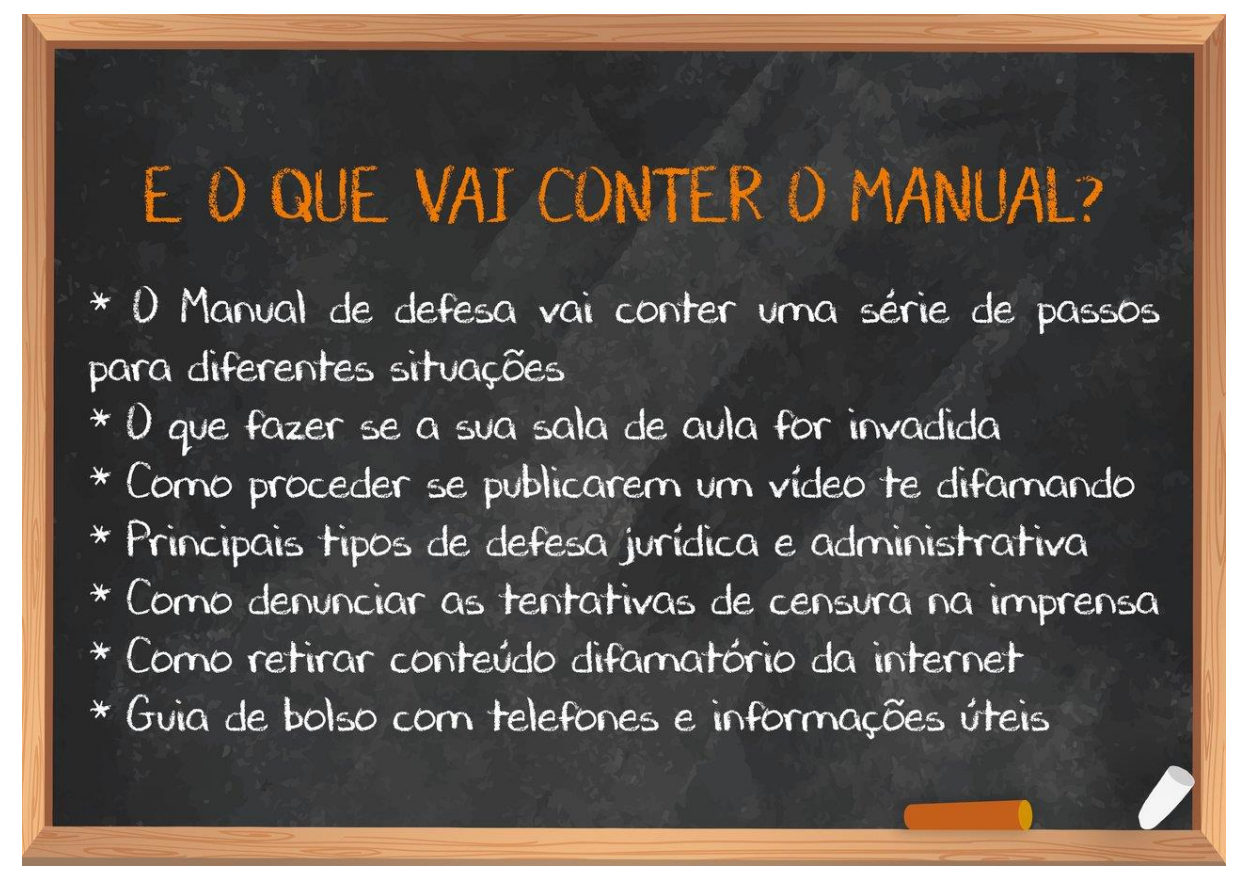

Figura 7 - Arte para site e redes sobre a campanha em torno do Manual - Fonte: Reprodução 4V

\footnotetext{
39 Ativista paquistanesa que luta pelo direito à educação.

40 Fundada em 1994, a Ação Educativa é uma associação civil sem fins lucrativos que atua nos campos da educação, da cultura e da juventude, na perspectiva dos direitos humanos.

${ }^{41}$ Ver mais em http://quatrov.com.br/mini-doc-manual-de-defesa-para-professores.html
} 
Para a continuidade da campanha foi aberta uma campanha de arrecadação que recebeu mais de $\mathrm{R} \$ 11$ mil. $^{42}$

Nessa campanha, a Agência Pressenza entrou como apoiadora e não como proponente, em que pese ter sido implantada pelas mesmas pessoas que atuam nos dois arranjos, o que nos fez refletir sobre quais eram os limites e diferenças entre eles.

A criação do coletivo e site $4 \mathrm{~V}$, assim como outras iniciativas, se deu em meio à polarização política e ataques ao Estado Democrático de Direito, que culminaram no impeachment da ex-presidente Dilma Rousseff.

Elaborado por membros da Agência Pressenza, antes das manifestações de rua que caracterizaram esse cenário, o $4 \mathrm{~V}$ ainda estava em processo de elaboração e condições de custeio, quando aumentou o número de pessoas nas ruas e a necessidade de produzir conteúdo em formato audiovisual fez com que o arranjo fosse formado "[...] da maneira que estava, sem esperar o financiamento." (Guilherme de Almeida, 2018)

Inspirado na política de comunicação do $\operatorname{Podemos}^{43}$ e nos programas Fort Apache, La Tuerca, do grupo de mídia mexicano Rompimientos, que exibia dois programas por dia, o $4 \mathrm{~V}$ foi fundado em 2015 para disputar narrativas com produção em audiovisual.

[...] foi em março de 2015, tinha umas 100 mil pessoas, e a gente ficou curioso, daí, depois disso, a gente falou não, uma coisa é "ah, precisamos de patrocínio, precisamos organizar melhor" não, vai do jeito que for agora, tem que ir, porque na mesma época, não foi só o fato de ter a marcha, começou a onda golpista, porque a Dilma tinha acabado de ser eleita, começou a ter uma profusão de vídeos, inundando as redes, os alarmistas dizendo que ia ter guerra, invasão não sei aonde, começou àquela época da turma dos Revoltados Online, [...] surgiu o MBL, surgiu... o Bolsonaro, não como é agora, mas essa turma do Bolsonaro surge mais forte ali, fascista, e a gente vê no nosso campo, do outro lado, mesmo da cultura de paz, movimentos de esquerda, sociais, populares, uma produção muito ínfima, muito pequena, então, a gente começa, primeiro, logo do jeito que dá, organizar uma produção, no mínimo semanal, e depois ela começa a ser mais ou menos diária. (Guilherme de Almeida, 2018)

É importante ressaltar que, embora a cultura do brasileiro seja muito relacionada à oralidade, os veículos e coletivos da comunicação alternativa utilizam pouco a linguagem audiovisual. Por outro lado, veículos e ativistas posicionados à direita no espectro político são campeões de acesso em plataformas como o Youtube.

\footnotetext{
42 Valor arrecadado até o fechamento da dissertação.

${ }^{43}$ Partido Espanhol de orientação de esquerda fundado em 2014.
} 
A partir dessa produção, o $4 \mathrm{~V}$ passou a ter notoriedade entre os outros arranjos, começou a frequentar as reuniões do Mídia Ninja, fundou os Jornalistas Livres e entrou em contato com o Outras Palavras que o convidou para fazer parte do Ateliê do Bixiga.

Ao lado dessa articulação com outros arranjos alternativos e com a experiência profissional em vídeos, o 4V tornou-se apoio aos movimentos de comunicação para fazer "[...] mesmo de forma econômica, mas com um mínimo de qualidade [...]" (Guilherme de Almeida, 2018) a produção audiovisual.

A ideia de "massas de mídias", de Ignacio Ramonet é, segundo Guilherme Almeida, a sustentação do $4 \mathrm{~V}$ e da política de relacionamento entre as iniciativas alternativas de comunicação. O jornalista francês, em 2012, escreveu:

Tudo muda muito rápido. Nós passamos da era das mídias de massa para a era da massa de mídias. Antes, as "mídias-sol", no centro do sistema, determinavam a gravitação universal da comunicação e da informação em torno delas. Agora, "mídias-poeira", espalhadas pelo conjunto do sistema, são capazes de aglutinar para constituir, em certas ocasiões, superplataformas midiáticas gigantescas... A lógica do predador solitário é sucedida pela estratégia do enxame. (RAMONET, 2012, p. 27)

Sem entrarmos nas transformações do poderio das empresas mundiais da comunicação ("mídias-sol”) e as relações atuais com as mídias menores, não necessariamente alternativas ("mídias-poeira"), o fato é que a evocação da "era da massa de mídia" foi o ponto de partida conceitual para criação de coletivos como o Mídia Ninja (que usa o termo desde a sua fundação até hoje em palestras e atividades) até o $4 \mathrm{~V}$ que reinterpretou isso da seguinte forma:

[...] ah, se os poderosos têm uma mídia de massa, vamos tentar organizar uma massa de mídias," pequenas mídias para confrontar a grande mídia. E o 4V começa a pegar mais essa característica, de ser uma parte, uma frente audiovisual da Pressenza, isso antes mesmo dessa marcha da família, a gente já tinha essa direção, mas aí, conforme o contexto se dá dessa maneira, a gente acaba indo nessa direção de tentar fazer uma massa de mídias. (Guilherme Almeida, 2018)

O arranjo passa a ser um braço da Agência Pressenza no formato que é especializado ao mesmo tempo em que é um novo coletivo que se articula quanto à produção e linha política com outros da área da comunicação alternativa.

Mesmo sendo "filha da Pressenza" (informação verbal) ${ }^{44}$, as decisões do $4 \mathrm{~V}$ não necessitam passar pelas reuniões de pauta internacional, assim como a resolução de ter um candidato a deputado estadual, como houve na última eleição. Ao lado disso, algumas pautas

\footnotetext{
${ }^{44}$ Guilherme de Almeida (2018), informação verbal coletada em observação de campo.
} 
que são debatidas no espaço internacional e nacional da Agência são produzidas pelos membros do arranjo que produz vídeo.

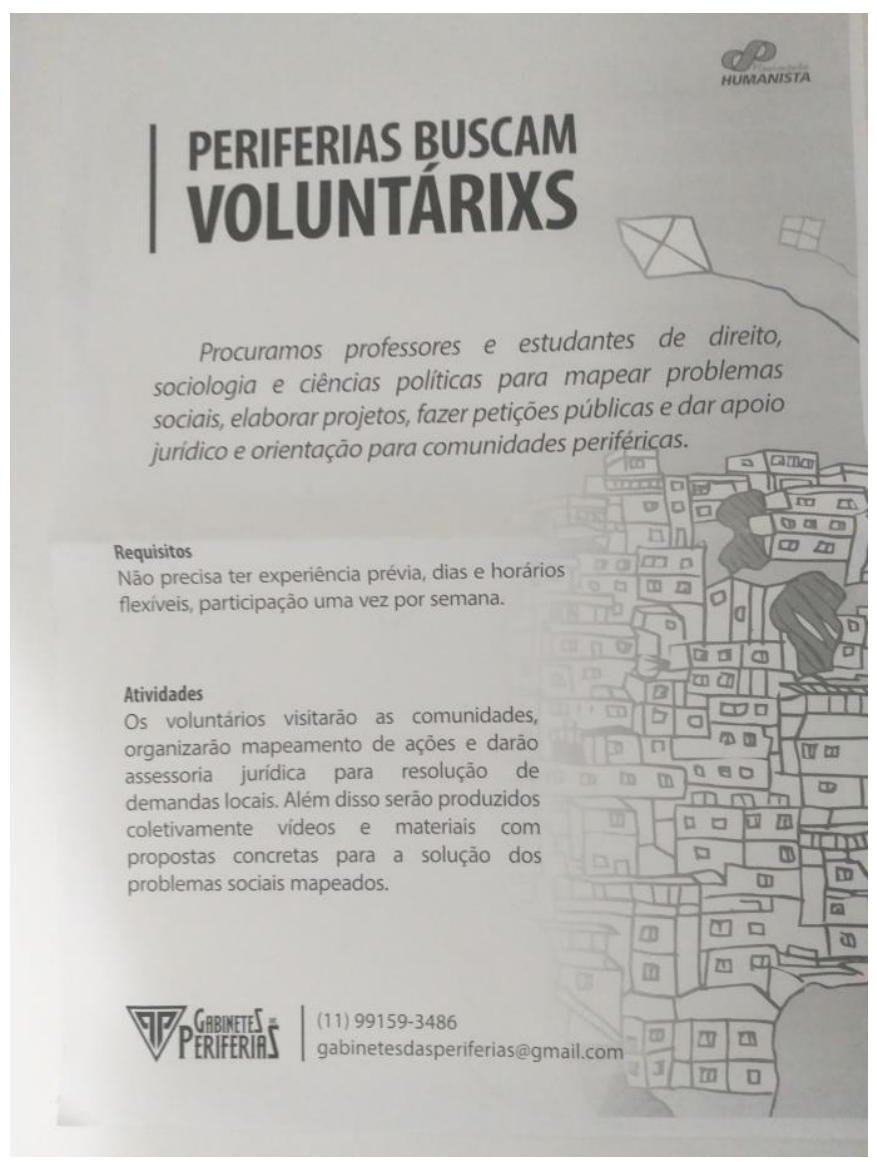

Figura 8 - Cartaz distribuído em escolas e universidades que visava ação eleitoral - Fonte: Imagem da autora

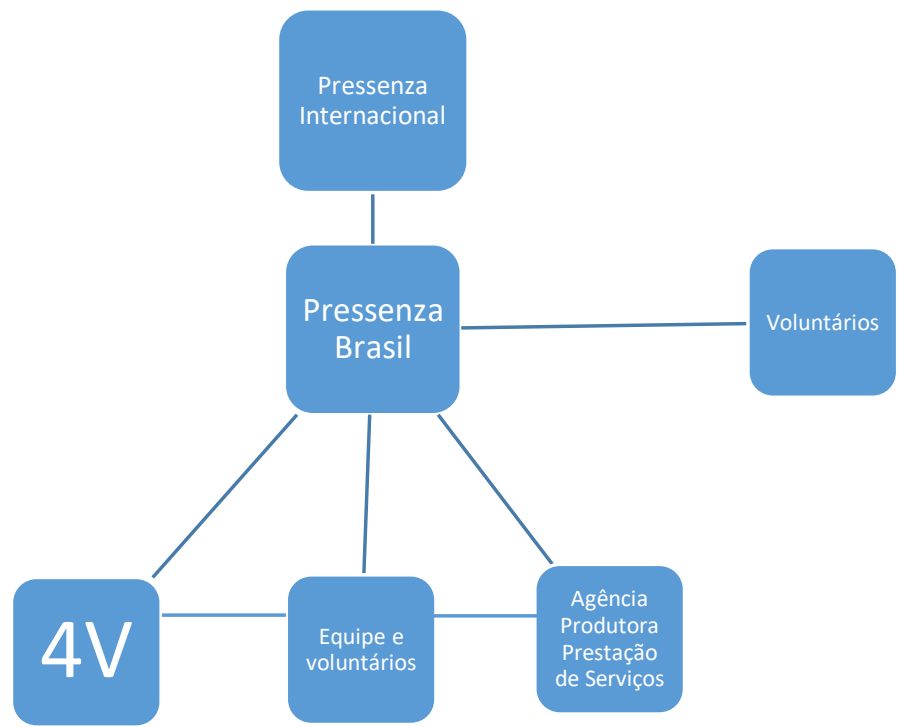

Figura 9 - Organograma da organização do Agência Pressenza Brasil - Fonte: A autora (2019) 
A relação entre as redações internacional e nacional se dá dentro do movimento humanista, causa fundante da Agência Pressenza, e nos dois níveis há a participação de colaboradores que a própria organização chama de "voluntários". Quando foi criado o arranjo 4V, a ideia era constituir um coletivo atuante na realização de programas em vídeo, porém com os altos custos da produção, a necessidade técnica e tempo para esse tipo de execução contar apenas com o trabalho "voluntário" era insuficiente.

[...] a grande diferença é que no caso do Pressenza, todo mundo é voluntário mesmo, e no caso do $4 \mathrm{~V}$, existe uma necessidade de fazer a produção visual, de ter o equipamento, de ter o estúdio, de ter pessoas que possam se dedicar mais horas para a edição [...]. Todo mundo, por exemplo, que ir para a captação, você consegue voluntários para captação, mas você não consegue voluntários de forma permanente. Você consegue de forma pontual, mas você não consegue de forma contínua quem faça edição de vídeo todo dia, precisava de uma grana para dar uma ajuda de custo, dar algum tipo de apoio para o pessoal poder destacar um tempo... Então, a gente começou a pegar os voluntários que já tinha de audiovisual, dar uma ajuda de custo, e para manter isso, a gente criou uma produtora que vende serviços. (Guilherme de Almeida, 2018)

Ainda de acordo com o entrevistado há casos em que "[...] 70\%, 80\% das decisões do 4V batem com os da Pressenza [...]”, mas já teve caso em que as decisões não coincidiram e houve "o respeito" desses limites.

A busca criativa pela liberdade e autonomia na atividade jornalística do ponto de vista do trabalho concreto, a normatização e renormatização desse processo de trabalho em relação à hierarquização da organização, na articulação com a equipe internacional fazem parte de um lado do pêndulo do trabalho. No outro lado tem uma situação precária para exercer o jornalismo no quadro ditado pela lógica toyotista com resquícios do modo de reprodução taylorista-fordista.

A produtora de serviços citada por Almeida é o terceiro arranjo que encontramos dentro do conjunto de relações de comunicação e trabalho. O intuito de sua criação foi sustentar economicamente tanto o $4 \mathrm{~V}$ quanto a Pressenza Brasil e, consequentemente, a Agência Internacional.

A saída de criar a produtora torna visível o valor do trabalho dos jornalistas. Isso não significa que não haja geração de valor no $4 \mathrm{~V}$ ou na Agência, ele apenas não é aparente. Essa é uma dimensão complexa advinda da reestruturação do capital em que as tecnologias de informação e comunicação são utilizadas para invisibilizar o valor como fórmula de geração de mais valor em todo o processo de produção capitalista. (ANTUNES, 2018) 
A resposta para criar valor de uso e valor de troca no serviço que vende através da produtora só foi possível porque há no sistema capitalista em sua fase atual a fragmentação do processo produtivo. Assim como as empresas montadoras que têm dividido em diferentes locais do mundo os itens da produção, no setor de comunicação também há a descentralização dos espaços de produção. Esse fato constitui, inclusive, atual desafio para a organização dos trabalhadores que separados tendem a uma resistência menor perante a retirada de direitos e ampliação da exploração da força de trabalho.

Uma grande empresa de mídia que vende um jornal impresso, por exemplo, tem segregada a sua produção desde a apuração da matéria jornalística com empresas que trabalham com jornalismo de dados; a elaboração da matéria é feita por jornalistas freelancer ou por pessoas jurídicas (a chamada pejotização); a fotografia também pode ser de outro profissional como pessoa jurídica, pequena empresa ou coletivo como o $4 \mathrm{~V}$; e a distribuição conta com uma quarta empresa para fazer com que o produto chegue às bancas e casas dos anunciantes.

Em cada etapa da produção há uma parte do trabalho não pago que é absorvida e geradora de mais valor no processo de produção da matéria jornalística.

O sentido da expressão valor aqui utilizada não caracteriza uma propriedade, um objeto ou determinado serviço, mas sim define as relações humanas sob quais são produzidas. “O valor é uma relação social tomada como uma coisa, uma relação de produção entre pessoas que toma a forma de uma propriedade das coisas." (RUBIN, 1980, p. 85)

Marx, no volume I, de O capital (p. 137), quando retira a poeira do óbvio sobre a criação e as formas de valor, expõe que valor de uso se dá somente no uso ou no consumo, sendo constituinte do conteúdo material do valor de troca. $\mathrm{O}$ valor de troca tem aparência, em seu início como quantidade, imanente e intrínseco à mercadoria, no entanto, a relação quanto ao valor de uso é alterada constantemente no tempo e espaço. "A forma de valor simples de uma mercadoria é, portanto, a forma simples de manifestação da oposição nela contida entre valor de uso e de valor." (idem, ibidem)

Compreendemos assim que o valor de uma mercadoria ou serviço é expressão do valor de uso de outra mercadoria ou serviço equivalente. Da mesma maneira o papel do trabalho como equipolente na criação de valor, conforme aponta Marx no exemplo que utiliza do valor do linho em sua obra (idem, p. 124): 
Não basta expressar o caráter específico do trabalho que cria o valor do linho. A força humana de trabalho em estado fluido, ou trabalho humano, cria valor, mas não é, ela própria valor. Ela se torna valor em estado cristalizado, em forma objetiva. Para expressar o valor do linho como massa amorfa de trabalho humano, ela tem que ser expressão como uma "objetividade" materialmente distinta do próprio linho e simultaneamente comum ao linho e a outras mercadorias.

Para criar valor de troca, a produtora vende a força de trabalho de seus membros para outra empresa, cujo objetivo de sua existência não é apenas produzir o vídeo, mas gerar maisvalia e ampliar o seu lucro, diferentemente do intuito do arranjo em sua forma primária (Agência Pressenza e 4V), cuja produção social não era pautada por uma visão mercantilista da informação.

Esse trabalho que cria valor, explicitado por Marx, está inserido em um ciclo contínuo de transformação do trabalho em valor, na criação em mercadoria, em dinheiro, mercadoria, em mais dinheiro etc. Esse trabalho é chamado pelos marxianos de trabalho produtivo. Entretanto, o mesmo trabalho pode ser produtivo e improdutivo. Vejamos o caso que estamos analisando do arranjo.

Dentro das relações de trabalho, o valor criado pelo trabalho não tem a intenção de gerar mais-valia. A produção da mercadoria vídeo é feita sem os fundadores do coletivo ou qualquer outra pessoa terem como objetivo acumular lucro. O tempo de trabalho para produzir a mercadoria é a forma de medida para remunerar os profissionais da produtora e o restante serve para ampliar os meios de produção, comprar equipamentos, softwares, pagar o aluguel da sede. Nessa forma social específica, o trabalho é improdutivo.

Já quando faz os vídeos sobre a biografia de Gandhi, Mandela e outros líderes humanistas para vender para uma empresa de publicidade que explora o espaço comercial da TV Ônibus, em São Luís do Maranhão, o mesmo trabalho passa a ser produtivo, porque tem participação ativa na valorização do capital da empresa. 


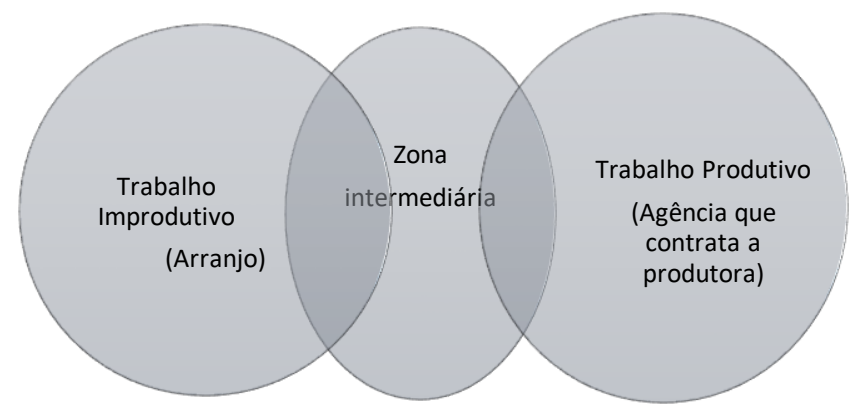

Figura 10 - Trabalho improdutivo e produtivo - Fonte: A autora (2018)

A definição de trabalho produtivo e improdutivo não tem relação com o trabalho imaterial ou material, mas sim como condicionante para converter mais-valia diretamente em capital. Essa é a diferença que delineia os dois tipos de trabalho. Entretanto, há fórmulas intermediárias que se interpenetram como ilustramos na figura 8.

Ao compreender o trabalho com a complexidade que esse tipo de relação social requer, Jean Lojkine (1980, p. 273) discorre sobre o avanço das forças produtivas e a chamada "revolução informacional" e, diante do cenário, aponta para o começo da constituição dos "produtivos improdutivos e improdutivos produtivos".

De acordo com o autor francês, o produtivo improdutivo se desenvolve com as funções informacionais no trabalho produtivo e o improdutivo produtivo se torna híbrido devido à perda de "referências identitárias" como estatuto do trabalho e mobilidade social.

Ao adotarmos a atividade de trabalho no capitalismo como um todo social, complexo e combinado (ANTUNES, 2018), essas determinações sobre os dois tipos de trabalho podem ser alargadas considerando um trabalhador coletivo. Nas palavras do próprio Marx:

Para ser produtivo, já não é necessário, agora pôr pessoalmente a mão na obra; basta ser um órgão do trabalhador coletivo ou executar qualquer uma de suas funções. [...] A determinação original de trabalho produtivo, derivada da própria natureza da produção material, permanece sempre verdadeira para o trabalhador coletivo, considerado como coletividade; mas ela já não é válida para cada um de seus membros isoladamente. (MARX, 2017, p. 577)

Portanto, ao produzir o vídeo para o seu empregador, trocando tempo de trabalho por dinheiro e ao produzir mais-valia, mesmo ao assumir uma forma contemporânea das relações 
de trabalho baseada na ausência de direitos e precarização do trabalho, o arranjo econômico prestador de serviços e o seu produto social são formas de valorizar o capital.

Diante dessa situação, os profissionais de comunicação têm jornada dupla, alguns até tripla quando aceitam um trabalho eventual fora da relação com a Agência Pressenza/4V. Trabalham dobrado para poderem exercer, mesmo dentro desse processo, o desenvolvimento de sua atividade de trabalho com mais autonomia e liberdade de criação, desempenhando certa práxis social para contribuir com o avanço da sociedade.

Contudo, como todo trabalho há rotinas prescritas e controle do exercício do trabalho. Vejamos, a seguir, como é feita a produção da matéria jornalística.

\section{Rotina produtiva no arranjo}

Como pudemos verificar, o trabalho não diz respeito somente à produção da matéria jornalística no arranjo. Diferentemente dos outros arranjos que analisamos, a rotina produtiva na Agência Pressenza precisa conciliar os diferentes trabalhos.

Esse cenário de ter atividades múltiplas exige do profissional da comunicação toda sua desenvoltura e polivalência para atuar em situações de intensidade do trabalho.

A fala sobre o trabalho de Tarso do Amaral, entrevistado para esta pesquisa, descreve suas atribuições da atividade concreta. Além de fazer o roteiro e a pré-pauta, ele auxilia na parte de captação, edição, cobertura de eventos, ajuda na gravação das entrevistas, do programa e faz transmissão ao vivo.

Dessas pautas, desses eventos, a gente estipula como vai ser trabalhada a semana, se vai ser tipo drops, se vai ser um programa ao vivo, algum evento que a gente vai cobrir, então, nesses três pilares assim, a gente define como vai ser a semana. Daí, dependendo do dia, é diferente. [...] A maioria do tempo, é conteúdo que eu faço. A gente também faz programas ao vivo, então faz aqui mesmo na produtora, então, a gente faz a montagem do equipamento, a outra jornalista cuida da parte da produção, então, ela traz os convidados... Daí, a gente grava ao vivo com duração de 27 minutos e transmite ele. No caso de coberturas externas de eventos, se tem alguma manifestação ou alguma marcha, alguma coisa assim do tipo, a gente faz o mesmo esquema de programa ao vivo, leva a ilha de edição lá, faz uma transmissão ao vivo, ou a gente só vai com as câmeras, capta o conteúdo, depois volta para cá, faz uma edição e libera o vídeo. (Tarso do Amaral, 2018)

Outro profissional, Marcelo Rodrigues, também pontua como divide o que tem que fazer. As ações da agência ficam em um documento no Google Drive e a primeira coisa que 
ele faz quando chega é acessar a pasta na nuvem. Formado em sociologia, trabalha durante três dias no arranjo, nos outros dias ele é professor de um cursinho pré-vestibular.

Em um dia ele atende a cliente A em diversas linguagens da comunicação. Produção de conteúdo, marketing digital, alimentação das redes sociais e designer e uma vez por mês ele edita um $e$-book para ela.

[...] eu edito e faço as artes do $e$-book e faz essa parte meio marketing de programar e-mail, depois nós vamos dar atenção para as pautas, pros programas por enquanto eu apresento o programa. [...] Voltando eu termino a parte da Cliente A, (quando acaba essa parte) vou dar atenção para o Presença e 4V. Aí tem o boletim que eu tenho que fazer, são os vídeos da semana, as pautas das matérias, normalmente eu escrevo um artigo para cada programa que eu vou apresentar para ter um certo domínio no mínimo do assunto na hora de falar sobre algo. (Marcelo Rodrigues, 2018)

A definição do que será feito na semana varia com a contratação de serviços da produtora e com a pauta da Agência Pressenza e do coletivo 4V. Se há muito trabalho remunerado, os profissionais da comunicação se organizam para cumprir toda a demanda.

Quando há manifestações ou movimentos políticos, esse tipo de cobertura domina a pauta e a organização se volta para esse tipo de trabalho.

Já as pautas da Agência Pressenza são abertas para indicação dos voluntários que podem participar através do grupo fechado no Facebook, com comentários nas matérias nas redes sociais e presencialmente na reunião de pauta. As pautas de vídeo são feitas pelo $4 \mathrm{~V}$.

Resumidamente, a matéria jornalística da Agência Pressenza/4V segue o seguinte caminho de produção:

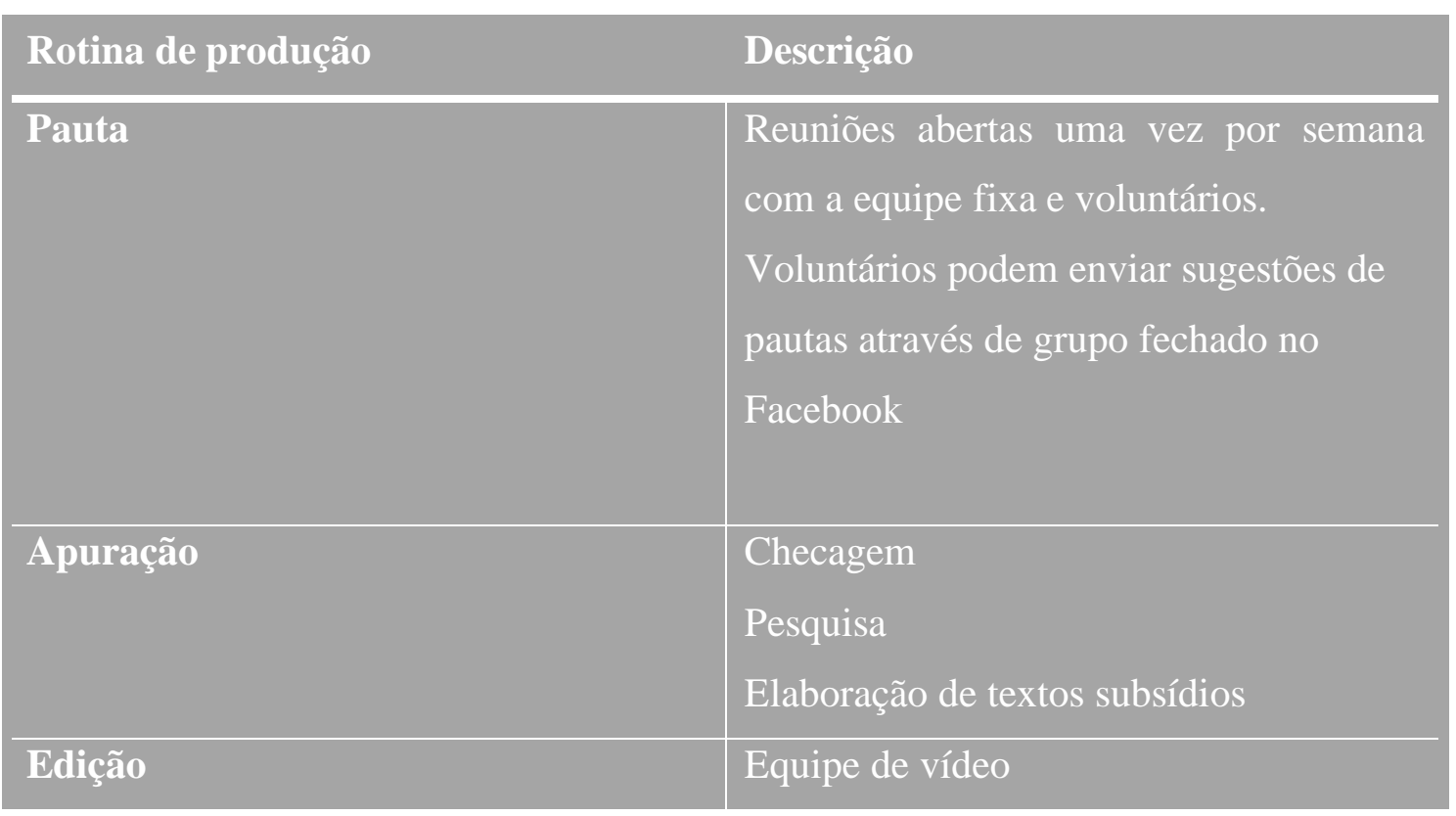


Tabela 1 - Caminho da produção jornalística Agência Pressenza - Fonte: A autora (2019)

Essa rotina produtiva é entrelaçada com a agência produtora e os conteúdos não são aproveitados entre as duas frentes de trabalho.

\section{O jornalismo produzido}

A criação de novos arranjos e a oferta de diferentes serviços, assim como nos outros arranjos econômicos pesquisados só é possível devido ao avanço e barateamento das tecnologias de informação e comunicação influenciam no jornalismo produzido pelo arranjo. Tarso do Amaral, durante depoimento, lembrou de quando estava na universidade e utilizava dois tipos de softwares para fazer edição e, atualmente as duas funções estão em um só. Destacou ainda a facilidade de fazer um programa ao vivo nas redes sociais e o contato mais próximo com as fontes.

[...] facilitou muito fazer jornalismo com novas tecnologias, tanto para manter contato, $[\ldots]$ a gente não precisa estar ligando ou indo pessoalmente, a gente já consegue entrar em contato já com o computador. Programa ao vivo também, muito dos programas que a gente faz, quando vai debater alguma pauta com um especialista, a gente faz esse contato por meio da internet, os próprios softwares também foram se aprimorando e em questão de pouco tempo. Eu me lembro da época que eu estudava, você precisava de dois softwares para fazer uma função, e hoje essa mesma função está automatizada em um software só. Quer dizer, antes você tinha que fazer manualmente, hoje, você aperta um play, ela faz tudo sozinha. Facilitou muito a produção do jornalismo. (Tarso do Amaral, 2018)

Mesmo com a facilitação das tecnologias, qual é o jornalismo possível de ser produzido em meio a tantas atribuições?

Embora tenham vontade de fazer reportagens e o jornalismo hardnews, não há as condições concretas para essa realização. Na reunião de pauta, o coordenador avisa que, como conseguem produzir pouco, é preciso "buscar profundidade" nas matérias com o objetivo de explicitar a pauta da não violência, estimular que as pessoas possam mudar o seu estilo de 
vida junto com a mudança política e que a narrativa feita pelo arranjo “[...] gere comunidades que tenham relação e convergência com outras [...]" (informação verbal) ${ }^{45}$

\begin{abstract}
A gente entende isso também, da hegemonia cultural como algo importante, a gente não menospreza isso, a gente faz isso também, mas a gente tem outro conceito que é de gerar matrizes culturais. Então, matriz cultural, que é um negócio que pouca gente conhece, é você gerar, assim, reportar modelos de conduta, de ação, principalmente coletiva, mais do que individual, que vão desarmando a violência do sistema, e a criminalização de todo o sistema capitalista [...] (Guilherme de Almeida, 2018)
\end{abstract}

Ainda de acordo com Almeida, a referência conceitual sobre matrizes culturais tem origem em conversas com o fundador do movimento humanista, o escritor Mario Rodrigues Luís Cobos, mais conhecido por seu pseudônimo literário Silo.
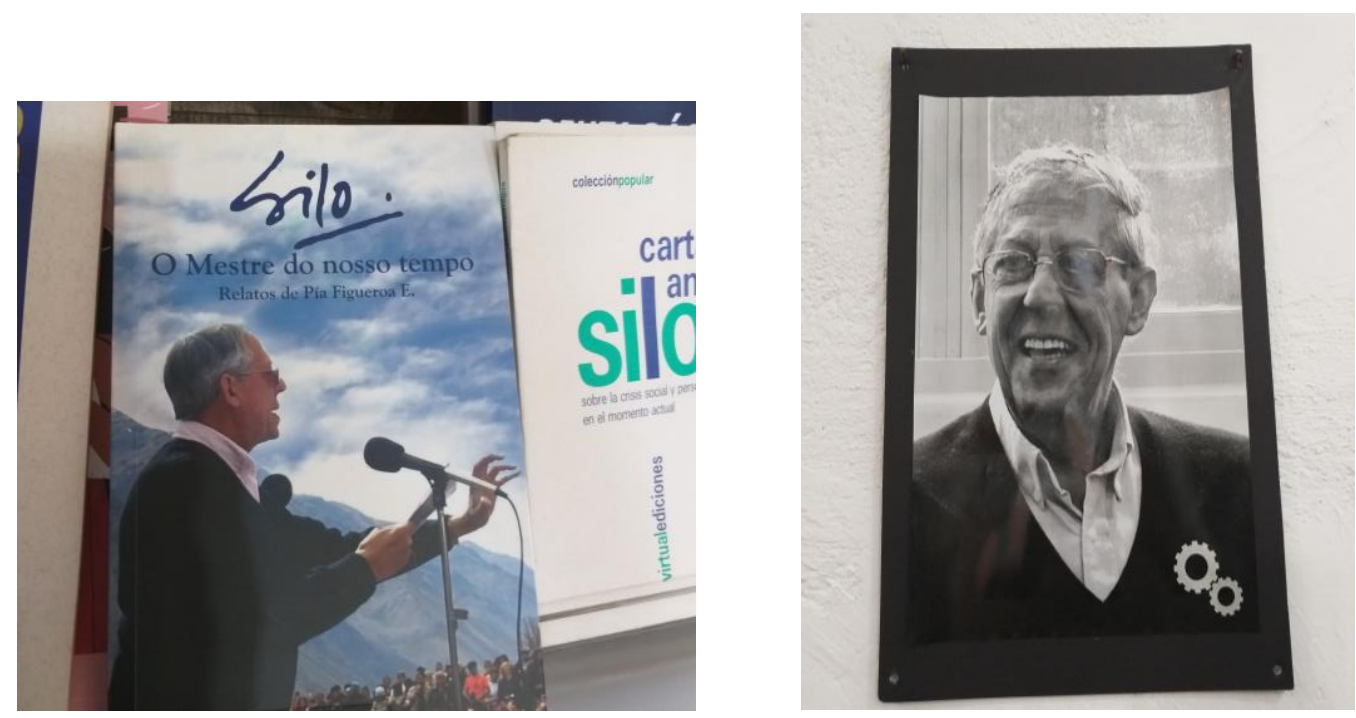

Figura 11 - Livros e a fotografia de Silo ficam em lugar de destaque na sede da Agência- Fonte: A autora (2018)

Em diálogo com as ideias de Luís Cobos, Gunther Aleksander, militante do movimento humanista no Brasil, apresentou em simpósio em Assunção, Argentina, o conceito de mídia humanista. Segundo sua apresentação, é no momento de crises pessoais e sociais em que há a possibilidade de rompimentos com situações cristalizadas por essas obrigarem os diálogos. Portanto, de acordo com o autor, é fundamental aproveitar os meios de comunicação e as redes sociais para conversar diretamente com as pessoas em circunstâncias de turbulências. Isso porque a motivação das "matrizes culturais" são apenas uma: a razão humana.

[...] estaremos hablando de las matrices desde un punto de vista cultural y existencial, donde las acciones de un conjunto humano generan " $n$ " posibilidades progresivas y divergentes, que generan historia social como una profunda autotransformación de su propia naturaleza. Misteriosamente las matrices culturales

\footnotetext{
${ }^{45}$ Fala de Guilherme de Almeida durante a reunião de pauta observada na pesquisa.
} 
se convierten en profundos modelos existenciales de comportamiento colectivo, generación tras generación. Una vez aclarado esto podemos entrar en el tema y contestar las preguntas que dieran inicio no solamente a este breve estudio más también a una acción decidida a generar nuevas matrices culturales (ALEKSANDER, 2016. p. 2).

Desse modo, para Guilherme de Almeida, a matriz cultural é também um método de interpretação dos fatos para promover uma abordagem dos fatos que visa ao futuro. Portanto, para o comunicador o tipo de jornalismo produzido pelo arranjo:

[...] é de reinterpretação. E como a gente tem a mania de analisar as coisas desde a metodologia da não violência e também reinterpretar as cosias de forma a abrir futuro[...] a gente não nega o passado, é óbvio, mas quando você trabalha a hegemonia, jornalismo baseado na disputa de relatos, e você fica muito mais nos porquês do passado, do que para que o futuro, e essa coisa da matriz, porque a matriz é essencialmente uma coisa de futuro, então, ela exige você pensar muito mais nas aspirações do que nas motivações. (Guilherme de Almeida, 2018)

Outra visão acerca da atividade jornalística baseia o trabalho de Marcelo Rodrigues, que acredita comunicar de forma clara para o seu público os fatos relevantes ou curiosos que merecem a atenção das pessoas.

Vejamos, a seguir, como essas duas concepções se materializam na produção jornalística coletada do site da Agência Pressenza Brasil entre os dias 01 e 07 de janeiro de 2019:

\begin{tabular}{|c|c|c|c|}
\hline Data & Editoria & Título & Descrição \\
\hline $\begin{array}{l}2 \text { de } \\
\text { janeiro }\end{array}$ & Política & $\begin{array}{l}\text { (Dossiê) } 17 \text { fatos provam que a eleição } \\
\text { de Bolsonaro foi totalmente } \\
\text { fraudulenta }\end{array}$ & Matéria própria \\
\hline $\begin{array}{l}2 \text { de } \\
\text { janeiro }\end{array}$ & $\begin{array}{l}\text { América do } \\
\text { Sul }\end{array}$ & $\begin{array}{l}\text { O governo Bolsonaro e a demarcação } \\
\text { de terras indígenas }\end{array}$ & $\begin{array}{l}\text { Matéria do Brasil de } \\
\text { Fato }\end{array}$ \\
\hline $\begin{array}{l}2 \text { de } \\
\text { janeiro }\end{array}$ & Política & $\begin{array}{l}\text { Bolsonaro primeiras medidas de } \\
\text { governo contradizem o discurso de } \\
\text { campanha }\end{array}$ & $\begin{array}{l}\text { Matéria do Brasil de } \\
\text { Fato }\end{array}$ \\
\hline $\begin{array}{l}3 \text { de } \\
\text { janeiro }\end{array}$ & $\begin{array}{l}\text { América do } \\
\text { Sul }\end{array}$ & $\begin{array}{l}\text { Chile e Argentina selam pacto contra o } \\
\text { novo "inimigo interno" }\end{array}$ & $\begin{array}{l}\text { Matéria do Le Monde } \\
\text { Diplomatique Brasil }\end{array}$ \\
\hline $\begin{array}{l}4 \text { de } \\
\text { janeiro }\end{array}$ & Ásia & $\begin{array}{l}\text { Muro de três milhões de mulheres pede } \\
\text { justiça de gênero na Índia }\end{array}$ & $\begin{array}{l}\text { Matéria da Prensa } \\
\text { Latina }\end{array}$ \\
\hline $\begin{array}{l}4 \text { de } \\
\text { janeiro }\end{array}$ & $\begin{array}{l}\text { Cultura e } \\
\text { Mídia }\end{array}$ & $\begin{array}{l}\text { Ataque cibernético atinge centenas de } \\
\text { políticos alemães }\end{array}$ & $\begin{array}{l}\text { Matéria da agência } \\
\text { alemã Deutsche } \\
\text { Welle }\end{array}$ \\
\hline $\begin{array}{l}4 \text { de } \\
\text { janeiro }\end{array}$ & $\begin{array}{l}\text { Paz e } \\
\text { Desarmamento }\end{array}$ & $\begin{array}{l}\text { Quem perde e quem ganha com a } \\
\text { liberação das armas de fogo no Brasil }\end{array}$ & $\begin{array}{l}\text { Matéria do Brasil de } \\
\text { Fato }\end{array}$ \\
\hline $\begin{array}{l}7 \text { de } \\
\text { janeiro }\end{array}$ & Oriente Médio & $\begin{array}{l}100 \text { dias para Alaa -família do ativista } \\
\text { egípcio conta os dias até sua libertação } \\
\text { da prisão }\end{array}$ & $\begin{array}{l}\text { Matéria da Global } \\
\text { Voices Online }\end{array}$ \\
\hline $\begin{array}{l}7 \text { de } \\
\text { janeiro }\end{array}$ & $\begin{array}{l}\text { Cultura e } \\
\text { Mídia }\end{array}$ & $\begin{array}{l}\text { No apagar das luzes, Temer extingue e } \\
\text { suspende cerca de } 130 \text { rádios }\end{array}$ & $\begin{array}{l}\text { Matéria do Brasil de } \\
\text { Fato }\end{array}$ \\
\hline
\end{tabular}




\begin{tabular}{|l|l|l|l|}
\hline $\begin{array}{l}\text { 7 de } \\
\text { janeiro }\end{array}$ & $\begin{array}{l}\text { América do } \\
\text { Sul }\end{array}$ & $\begin{array}{l}\text { Povos indígenas denunciam desmonte } \\
\text { da Funai }\end{array}$ & Matéria do Sul 21 \\
\hline $\begin{array}{l}\text { 7 de } \\
\text { janeiro }\end{array}$ & $\begin{array}{l}\text { Ecologia e } \\
\text { Meio } \\
\text { Ambiente }\end{array}$ & $\begin{array}{l}\text { Tempo de incertezas e esperança } \\
\text { Matéria própria }\end{array}$ & \\
\hline
\end{tabular}

Tabela 2 - Títulos coletados na amostragem (de 1 a 8 de janeiro de 2019) - Fonte: A autora (2019)

Nesse período específico, na primeira semana do ano de 2019, houve duas matérias próprias. A primeira buscou denunciar a eleição presidencial e utilizou uma série de camadas de texto com links de sites parceiros, imagens, vídeos próprios de outros veículos e acontecimentos importantes para reiterar o discurso de fraude eleitoral. A outra, do dia 7 de janeiro, visou divulgar a resolução de evento da área de meio ambiente ao mesmo tempo em que aplica a visão do movimento humanista, que prega que toda crise é também uma oportunidade para estabelecer o diálogo com as pessoas.

As outras matérias das agências ilustraram tanto a não produção do arranjo como a importância das agências no fornecimento de matérias para sustentar arranjos que trabalham com escassos recursos humanos e outras dificuldades para manter os veículos atualizados. Em meio a milhares de conteúdos publicados na internet, percebemos que a Agência Pressenza seleciona material em que a informação é tratada de acordo com técnicas jornalísticas.

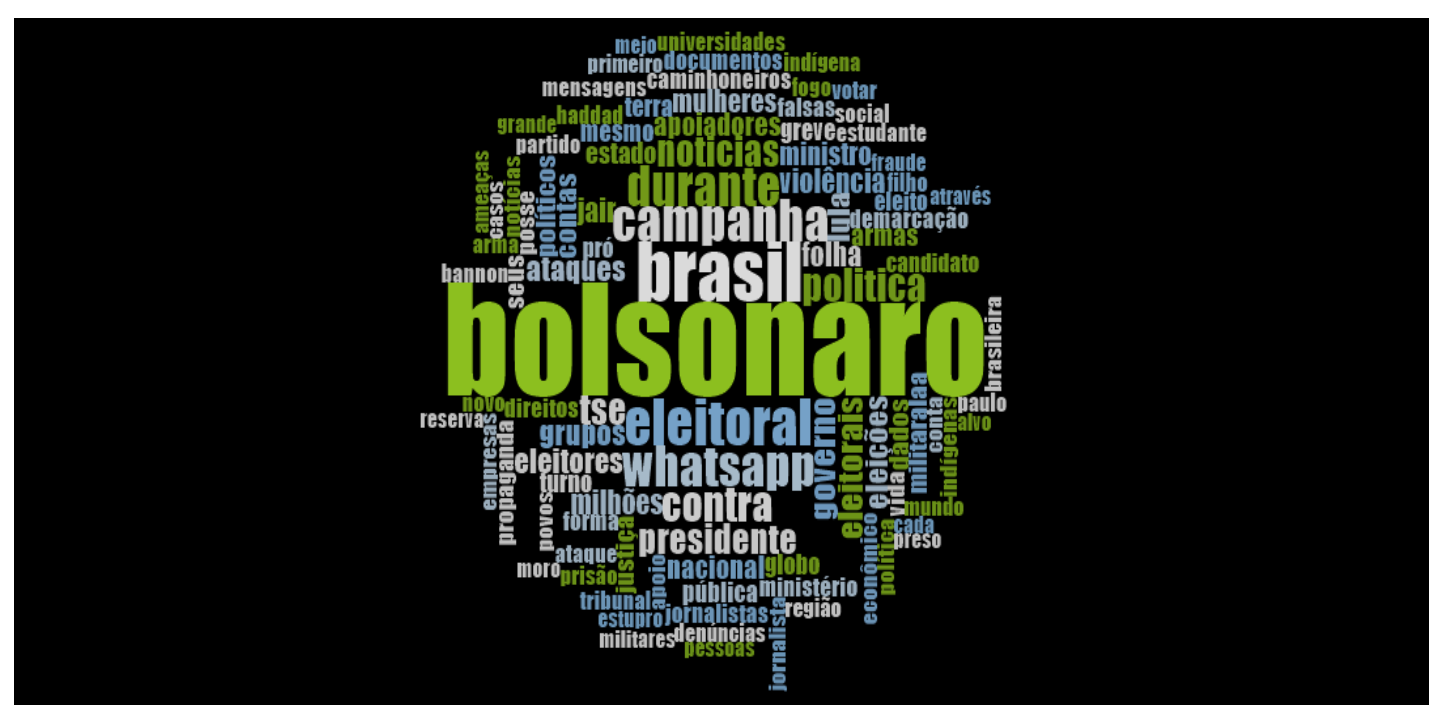

Podemos perceber que mesmo sem produção própria nos primeiros dias do governo de Jair Bolsonaro, a Agência buscou prolongar o debate realizado nas eleições e denunciar tanto o esquema utilizado para a vitória do presidente quanto para expor as medidas anunciadas que são contrárias ao posicionamento do arranjo. Há também a cobertura de acontecimentos 
internacionais sintetizadas nas editorias América do Sul, Ásia e Oriente Médio e alinhadas com a Pressenza Internacional.

Não é possível identificar no período da coleta a periodicidade de veiculação de matérias, mas sim a atualização sem estabelecer compromisso de todos os dias, por exemplo, trazer novas notícias para o público.

Passamos agora ao próximo arranjo analisado, os Jornalistas Livres. 


\section{Jornalistas Livres}

Como já apresentamos, as iniciativas jornalísticas alternativas aos conglomerados de mídia têm uma relação direta ao contexto social e foram criadas a partir de uma necessidade histórica. A fundação dos Jornalistas Livres é marcada pela urgência de narração e da análise das manifestações contra e a favor ao impeachment da ex-presidente Dilma Rousseff, em 2015.

As jornalistas iniciantes da movimentação para cobertura são oriundas de redações de grandes empresas e tinham contatos com outras redações. Foi assim que descobriam o plano de cobertura da Rede Globo sobre a manifestação do impeachment de 15 de março de 2015. Tinha uma conversa nos bastidores da TV que toda a programação planejada da emissora cairia para dar espaço às manifestações. "Isso nunca aconteceu em nenhum lugar do mundo. Cobrir em tempo real todas as manifestações. Foi aí que pensamos em nos reunir e fazer a cobertura dos atos", relembrou Maria Filomena em entrevista.

Alinhado com o núcleo de poder que trabalhava para a saída da então presidente, o maior conglomerado de mídia no país atuou como linha auxiliar na divulgação dos atos, interrompendo programas para transmiti-los ao vivo, desde às 9 horas até o final do dia de domingo.

Nesse caso específico, podemos observar duas características importantes. A primeira é o papel da mídia monopolizada na disputa do poder central do país; a segunda é que mesmo ela não é homogênea ou monolítica.

Ianni (1998) cita a disputa entre os meios de comunicação como geradores de “[...] relatos, análises, interpretações e fabulações que pluralizam e democratizam a mídia [...]." Além desse fator, indica também os "[...] inúmeros intelectuais de todos os tipos, jornalistas, fotógrafos, cineastas, programadores, atores, entrevistadores, redatores, entre outros que diversificam, pluralizam, enriquecem e democratizam a mídia (IANNI, 1998, p. 22).”

Foi justamente um profissional da empresa que revelou a estratégia da Globo para impulsionar a cobertura e o número de participantes da manifestação pro-impeachment para as fundadoras do Jornalistas Livres.

Até chegar ao dia da cobertura desses atos, o nascimento do Jornalistas Livres é perpassado por outras experiências. Três das cinco entrevistadas nesta pesquisa atuaram no 
projeto social Becos e Vielas, que tinha entre os seus objetivos capacitar jovens da periferia sul da cidade de São Paulo para elaboração do próprio jornal para retratar a comunidade. A ação voluntária envolveu jornalistas das grandes redações e chegou a durar dez anos.

Ainda antes dos Jornalistas Livres, profissionais que fundaram o coletivo de mídia fizeram parte da Ponte Jornalismo ${ }^{46}$ e contaram também com o apoio de outra mídia alternativa, a Agência Pública, que cumpriu a função de incubadora, cedendo espaço físico, acompanhamento das reuniões etc. Esse fato demonstra outros laços e valores comuns entre membros da mídia alternativa. Mesmo havendo diferenças, a ação conjunta é mais comum e presente.

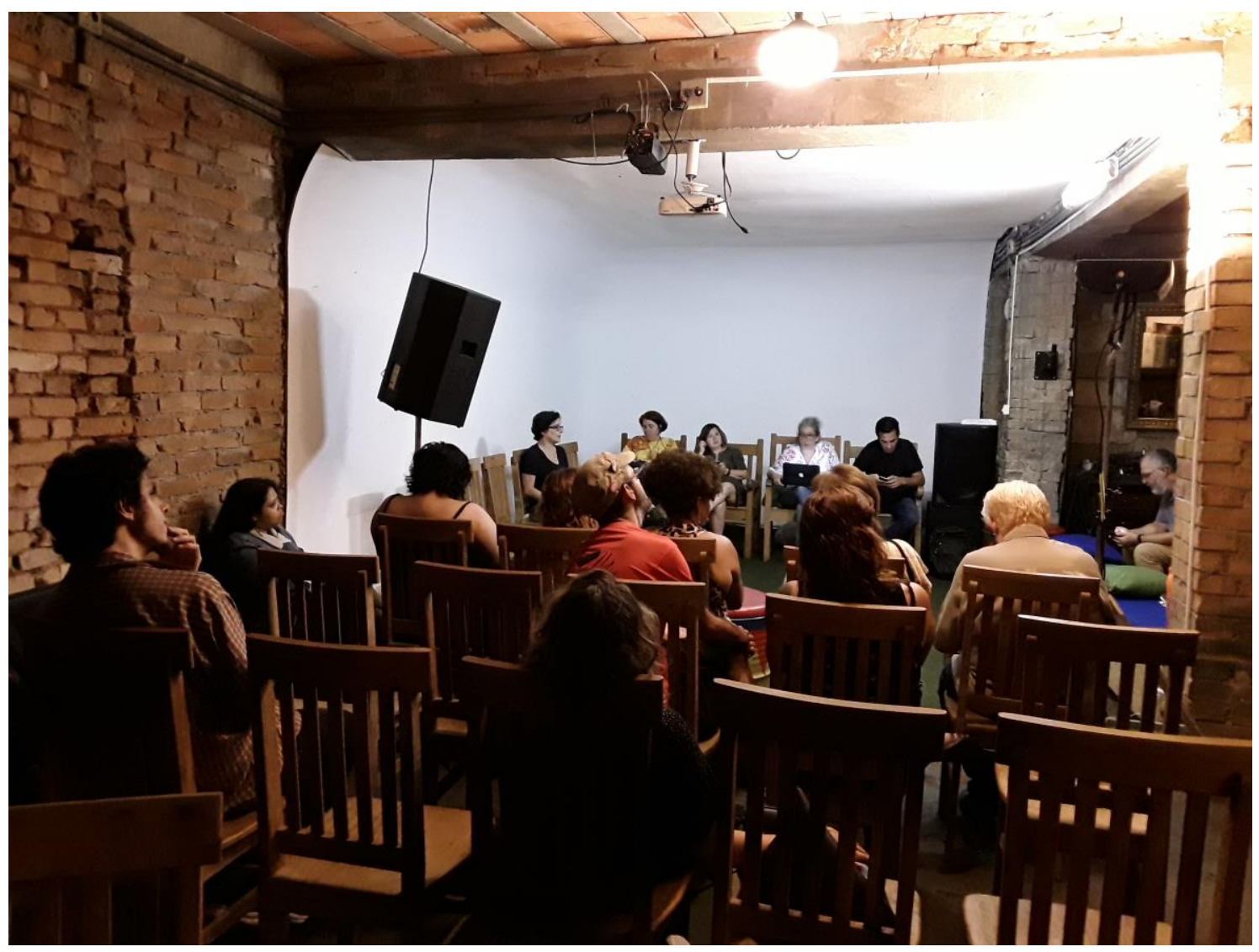

Figura 12 - Reunião de pauta presencial dos Jornalistas Livres no Ateliê do Bixiga

A relevância adquirida em pouco tempo em sites de redes sociais foi responsável pela fundação do coletivo. Nos primeiros dias de cobertura, a página criada no Facebook para divulgar o conteúdo elaborado coletivamente obteve êxito, o "dobro de curtidas que a Conta

${ }^{46}$ Veículo que cobre a pauta de segurança pública e direitos humanos. 
D’Água ${ }^{47}$, em um final de semana”. Essa métrica impulsionou a ação de jornalistas para formar o coletivo.

[...] porque no dia 13 que era sexta-feira no ato da esquerda, a gente criou o nome da página Jornalistas Livres, logo audiovisual, Twitter, Facebook de um dia para o outro. E foi daí que a gente tirou a importância dessa cobertura que era um pouco inspirado no Conta d'água, porque a gente sabia que a grande imprensa tentaria invisibilizar a sexta-feira como se não existisse, como se não tivesse tido ato, ou criminalizar, fazer aquela narrativa que a gente já conhecia, e a tratar o domingo como aquela super festa da democracia. (Entrevistada do Jornalistas Livres, CPCT, 2017)

A entrevistada Mônica Galvão credita à internet a possibilidade de fazer jornalismo colaborativo. ${ }^{48}$ As redes e o site do coletivo somente são possíveis por causa da tecnologia.

É um coletivo de jornalistas. Isso é uma coisa que só a internet permitiu e as redes sociais permitem. Você não poderia nunca ter os JLs sem isso, sem que fosse possível o cara de Vitória da Conquista mandar uma colaboração via inbox do Facebook e pedir para gente publicar. Qualquer pessoa pode ser um jornalista livre, e se empoderar. Basta ele pedir e ele entra no Publicadores ou no Colaboradores (Mônica Galvão, 2018).

O nome Jornalistas Livres foi definido pelos participantes (cerca de 60 jornalistas) que se juntaram para mostrar o que não era veiculado na mídia. "Nós escolhemos Livres porque aqui é o espaço para o jornalista ser livre de todas as amarras, das amarras da redação, do modelo de fazer jornalismo [...]”; “[...] como espaço de militância para o jornalista que estava na redação [...]”, descrevem respectivamente Mônica Galvão e Ana Cláudia da Silva, em entrevista. Ambas já trabalharam na grande imprensa. Essas falas mostram o ímpeto desses jornalistas para uma ação social a partir do jornalismo.

Desde a forma de organização do trabalho às pautas pode-se inferir uma propensão para a produção jornalística contrária ao jornalismo realizado nas corporações de mídia.

Na fundação do JL participaram arranjos, como a Mídia Ninja, Centro de Estudos da Mídia Alternativa Barão de Itararé, Opera Mundi, Outras Palavras (esses dois partícipes desta pesquisa), Democratize, jornalistas oriundos ou que trabalhavam em grandes empresas, ativistas da área da comunicação.

A entrevistada Cláudia Abraão descreve o arranjo como um movimento pela ausência de métodos organizativos. "De certa maneira, empiricamente muita gente cansa, se irrita, desiste e depois volta, mas o JLé um movimento."

\footnotetext{
47 Articulação de arranjos alternativos de comunicação para cobertura da crise hídrica durante a gestão de Geraldo Alckmin em São Paulo em 2013 e 2014.

48 Adiante, vamos discutir o jornalismo desenvolvido pelo Jornalistas Livres.
} 


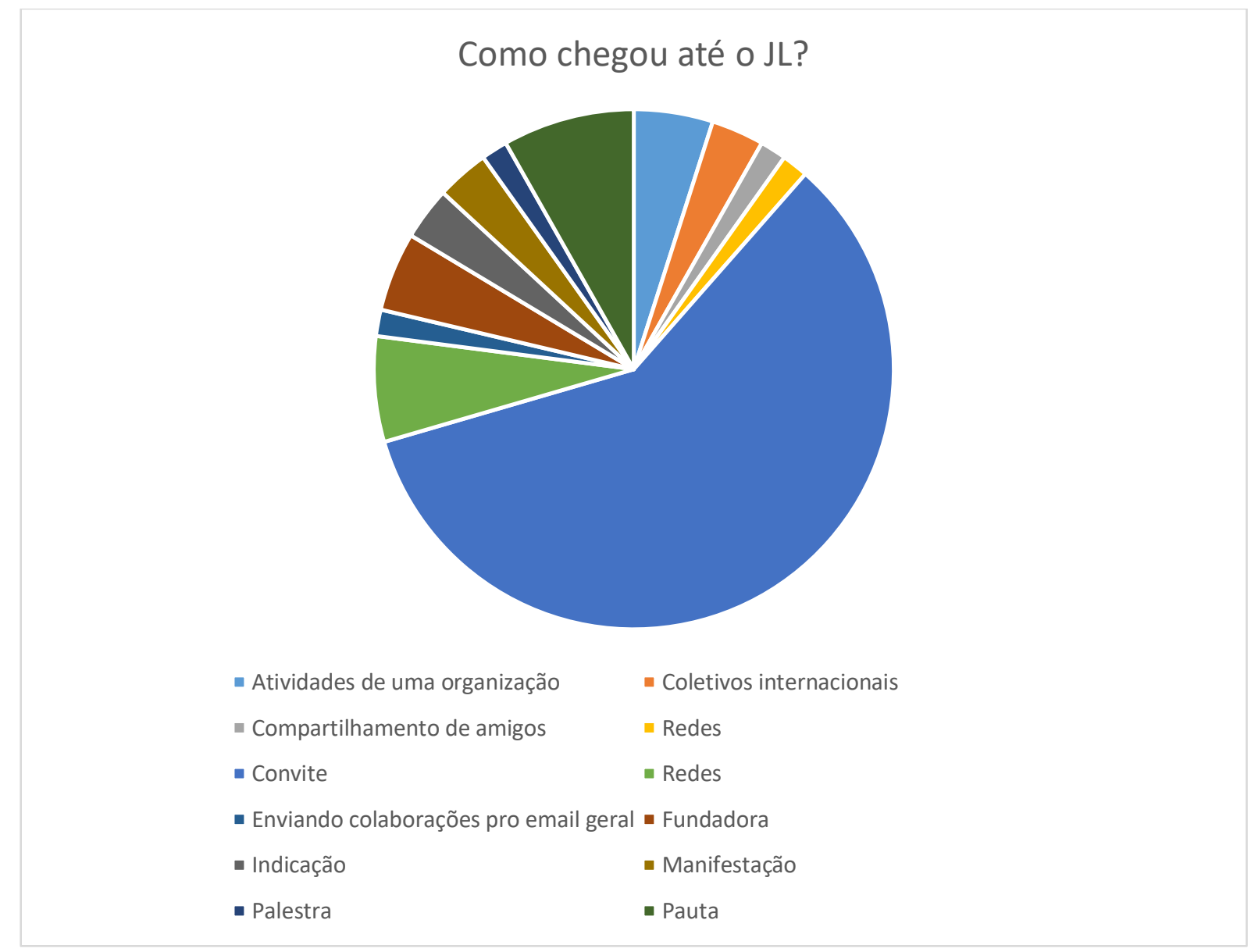

Como podemos aferir no quadro anterior, a maior parte dos membros chegam ao arranjo através de convite de pessoas que já participam, outras através da colaboração em rede, pela necessidade de falar sobre determinada pauta e utilizar o coletivo para alavancar e evidenciar um assunto ou aqueles que conheceram o JLs durante uma palestra.

Os coletivos e ativistas foram mobilizados pela pauta política daquele momento. Os jornalistas, em meio a uma acentuada polarização política, revelam a busca por um espaço de ação social por meio do jornalismo, buscam o reconhecimento da função social da profissão.

Atualmente, uma das tarefas do JL é organizar todos os membros "da marca", como definiu Mônica Galvão. Fazem parte do coletivo: jornalistas diplomados, jornalistas sem diploma, ativistas da comunicação, membros de entidades, partidos, sindicatos, jornalistas ocasionais, fotógrafos, chargistas, economistas etc. 
O desafio atual é como organizar todas as pessoas que querem contribuir com o arranjo. São centenas de pessoas que organizam o seu trabalho nas 80 redações virtuais que conformam a produção total do arranjo.

\section{Redação virtual: o papel da tecnologia na organização do trabalho}

Antes de iniciarmos a análise sobre a função da tecnologia na organização do trabalho específico do Jornalistas Livres é preciso compreender como o modo de produção influi nos arranjos alternativos.

Entre as características gerais, a moldura de nossa análise é a etapa de financeirização do capital e isso faz com que os monopólios de comunicação em escala mundial, com a convergência entre mídia, telecomunicações e informática, consigam aproveitar o mesmo produto em distintas plataformas. Segundo Denis de Moraes (2013, p. 22), a mesma produção é utilizada em diferentes meios de "[...] transmissão, distribuição, circulação, exibição e consumo, fazendo sobressair a mais valia na economia digital."

[...] Bancos e fundos de pensão passaram a investir atraídos pela expectativa de alta rentabilidade com a explosão digital. Isso significou uma intersecção cada vez maior entre capital financeiro e capital midiático, cujas as principais evidências são: a) garantia de suporte financeiro à aguda internacionalização da indústria de bens simbólicos; b) financiamentos bancários a compras, fusões e infraestrutura tecnológica; c) sociedade e participações cruzadas que asseguram aos bancos cotas acionárias e parcerias em projetos de entretenimentos.; e d) interferência do trade financeiro em ações estratégicas dos conglomerados de comunicação. (MORAES, 2013, p. 24)

O impacto da incorporação da comunicação como substância e qualificadora do capital financeiro tem resultado direito nas relações de trabalho. Muniz Sodré classificou em seu livro A ciência do comum: notas para o método comunicacional o binômio financeiro e comunicacional como características dessa etapa do capital e "[...] que a comunicação em sua prática, é a ideologia mobilizadora de um novo tipo de força de trabalho.” $(2014$, p. 85$)$

A tecnologia esteve no centro da reestruturação tanto da crise do capital de 1973 quanto na de 2007-2008. De acordo com Ursula Huws (2017), o desenvolvimento de novas tecnologias e a precarização do trabalho foram instrumentalizadas para sanar o colapso da criação de valor. 
Essa reestruturação da produção capitalista tem caráter permanente. Em 1973, para dar outros tipos de respostas que o modelo rígido do taylorismo-fordismo já não atendia, deu-se a implantação do modelo flexível japonês toyotista, que tinha como lema: "Bons pensamentos significam bons produtos”. Almejava-se também a subjetividade e o intelecto do operário. Não adiantava mais fazer todos os movimentos manuais que julgavam ser automáticos, mas os pensamentos do trabalhador deveriam ser todos "entregues" e direcionados ao processo de produção. As atribuições antes eram bem definidas, a produção em escala, jornadas de trabalhos fixas, a figura do gerente que controlava a qualidade, características alteradas para o trabalho flexível, a fragmentação da jornada de trabalho, acúmulo de funções em que cada trabalhador faz também o controle do próprio trabalho.

De acordo com a pesquisa Comunicação e trabalho: as mudanças no mundo do trabalho nas empresas de comunicação (2013), a partir da reorganização do modo de produção capitalista "[...] os jornalistas tornaram-se multifuncionais e polivalentes [...]", tendo que atuar em diferentes áreas da comunicação, de gestão e de administração. Assim, o profissional da comunicação tem que atuar em diferentes funções, desenvolver habilidades para manejar diferentes tipos de linguagens e gêneros de comunicação, além de dominar diferentes softwares e sistemas tecnológicos. Portanto, ele é responsável pelo trabalho de mais de uma perfil profissional em diferentes funções.

Para o jornalismo, essas mudanças significaram acúmulo de tarefas, extinção de cargos e funções, estabelecimento de metas de produtividade e alto investimento em tecnologia e softwares, que representavam automatização de tarefas tornando-as mais ágeis e rápidas, de forma a permitir que, no mesmo período de trabalho, um mesmo profissional assuma outras atribuições. (FÍGARO; GROHMANN; NONATO, 2013, p. 164)

As transformações da divisão sócio-técnica do trabalho em plena financeirização do capital têm, entre outras características, a diluição do enquadramento profissional. A exigência da polivalência está articulada, a nosso ver, com dois elementos: 1) o crescimento do setor de serviços que exige outras técnicas do trabalho diferentes das capacidades do modo de produção fabril como no período fordista-taylorista; 2) com o crescimento do desemprego estrutural e seus derivados como a desregulamentação e o aumento da precarização do trabalho. 
Ao utilizar uma visão ampliada do trabalho com o conceito "a-classe-que-vive-dotrabalho"49 tem-se uma "[...] conformação mais fragmentada, mais heterogênea, mais complexificada, mais polissêmica, mais multifacetada [...]" do mundo do trabalho. (ANTUNES, 2005, p. 83)

Podemos nos aproximar das funções exigidas para o fazer jornalístico atual ao analisarmos a tabela a seguir. Entre $62 \operatorname{membros}^{50}$ do coletivo, apenas cinco apontaram fazer uma única atribuição. Cada linha corresponde a uma resposta individual:

\begin{tabular}{|l|}
\hline Reportagem, foto \\
\hline Reportagem, foto, vídeo, revisão de texto, texto/notas \\
\hline Reportagem, foto, vídeo, texto/notas \\
\hline Foto, vídeo, ilustração, charge \\
\hline Reportagem, foto \\
\hline Foto, vídeo, edição de vídeo, revisão de texto \\
\hline Reportagem, foto, vídeo, edição de vídeo, diagramação do site, GIF, ilustração \\
\hline Reportagem, foto, vídeo, revisão de texto, texto/notas \\
\hline Diagramação do site, texto/notas \\
\hline $\begin{array}{l}\text { Reportagem, foto, vídeo, edição de vídeo, diagramação do site, GIF, revisão de texto, } \\
\text { texto/notas, tradução inglês }\end{array}$ \\
\hline $\begin{array}{l}\text { Reportagem, foto, vídeo, diagramação do site, revisão de texto, texto/notas, tradução espanhol, } \\
\text { base (post tempo real) e live o/ }\end{array}$ \\
\hline Polivalente total \\
\hline Reportagem, foto, vídeo, ilustração, charge, texto/notas \\
\hline Reportagem, texto/notas \\
\hline Reportagem, foto, vídeo, edição de vídeo, diagramação do site, revisão de texto, texto/notas \\
\hline Foto, vídeo, tradução espanhol \\
\hline Foto, vídeo, edição de vídeo, diagramação do site, GIF, texto/notas, tradução espanhol \\
\hline Foto \\
\hline Reportagem, foto, vídeo, texto/notas \\
\hline Reportagem, revisão de texto, texto/notas, tradução espanhol, tradução inglês \\
\hline Foto, vídeo, tradução inglês \\
\hline Reportagem, foto, vídeo \\
\hline Reportagem, revisão de texto, texto/notas \\
\hline Reportagem, tradução espanhol \\
\hline $\begin{array}{l}\text { Compartilhamento de matérias em grupos e perfis do Facebook, } \\
\text { administradora do Fórum de Leitores dos Jornalistas Livres, colaboradora em organização de } \\
\text { entrevistas }\end{array}$ \\
\hline
\end{tabular}

${ }^{49}$ Conceito presente em Adeus ao trabalho - Ensaio sobre as metamorfoses e a centralidade do mundo do trabalho e em Os sentidos do trabalho - Ensaio sobre a afirmação e a negação do trabalho, ambos de autoria de Ricardo Antunes.

${ }^{50}$ Cadastro feito pelo próprio JL em 2017. 
Reportagem, foto

Foto

Reportagem, foto, vídeo, edição de vídeo, revisão de texto, texto/notas, tradução espanhol, tradução inglês, tradução francês

Reportagem, texto/notas

Reportagem, foto, vídeo, edição de vídeo, texto/notas, tradução inglês

Reportagem, foto, vídeo, edição de vídeo, revisão de texto, texto/notas

Foto, vídeo

Reportagem, foto, vídeo, edição de vídeo, diagramação do site, GIF, ilustração

Foto

Mobilizo alunos

Reportagem, revisão de texto, tradução espanhol, tradução inglês

Reportagem, foto, vídeo, edição de vídeo, diagramação do site, revisão

de texto, texto/notas

Reportagem, foto, vídeo, edição de vídeo, texto/notas

Reportagem, foto, vídeo, edição de vídeo, diagramação do site, revisão de texto, texto/notas

Foto, vídeo, texto/notas, tradução inglês

Reportagem, foto, texto/notas, tradução espanhol

Reportagem, foto, ilustração, texto/notas

Texto/notas, cobertura de eventos relevantes em DC

Foto, vídeo, texto/notas

Reportagem, vídeo, revisão de texto, texto/notas

Reportagem, foto, vídeo, edição de vídeo, revisão de texto, texto/notas, tradução inglês

Vídeo, edição de vídeo, ilustração

Vídeo, edição de vídeo

Reportagem, foto, vídeo, tradução espanhol, tradução inglês, tradução francês

Reportagem, foto, vídeo, tradução francês

Reportagem, texto/notas

Reportagem, foto, ilustração, texto/notas

Artes e educação, ativismo feminista

Foto, texto/notas, tradução inglês

Reportagem, foto, vídeo, edição de vídeo, revisão de texto, texto/notas, tradução inglês, tradução francês

Reportagem, foto, vídeo

Foto

Reportagem, foto, texto/notas

Reportagem, foto, vídeo, revisão de texto, texto/notas, pau para toda obra (mas sem tempo)

Reportagem, foto, vídeo, tradução inglês

Reportagem, vídeo, revisão de texto, texto/notas

Reportagem, foto, vídeo, edição de vídeo

Reportagem, foto, vídeo

Tabela 3- Levantamento feito pela autora a partir de declaração dos 62 membros em questionário on-line -Fonte: A autora (2018) 
No novo cenário mediado pelas tecnologias, a polivalência, elemento essencial do toytismo, ao mesmo tempo em que extingue o enquadramento profissional, cria outras funções e ações, inclusive com nomenclatura inusitada. Exemplos: "basear" é igual a fazer base, ou seja, organizar o que será postado, aprovar, editar e postar o conteúdo nos sites e redes sociais. Há também a função de "guarda-senhas", que é a pessoa que resolve os problemas nas plataformas, mantém a vigilância em caso de ataque cibernético e organiza as pessoas que podem realizar publicações.

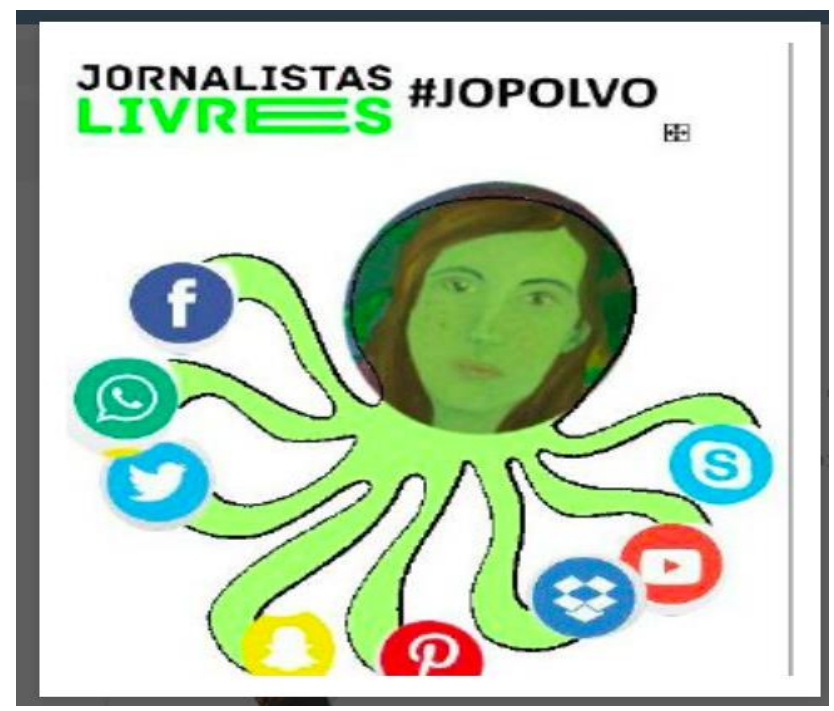

Figura 13 - Imagem coletada na observação da redação virtual - Fonte: Reprodução da redação

De acordo com Yves Schwartz, o trabalho é sempre inédito e ao “[...] utilizar uma técnica supõe, por um lado, seguir operações predefinidas e, por outro, uma certa reinvenção local." (2008, p. 87)

A partir dessa visão, os membros do JLs, ao mesmo tempo que usam as prescrições estabelecidas também criam outras normas, renormatizando a atividade jornalística em um ciclo dialético contínuo.

Os trabalhadores do conhecimento (HUWS, 2013) - nas empresas ou pertencente ao exército de reserva - atualmente contam com formas de horizontalização do capital produtivo e as "[...] modalidades de flexibilização e desconcentração do espaço físico produtivo, da introdução da máquina informatizada [...]", conforme descreveram Antunes e Alves em artigo intitulado As mutações do mundo do trabalho na era da mundialização do capital. (2004, p. 342) 
Esse processo todo acontece no seio do desenvolvimento da atividade de trabalho, incluindo o espaço virtual. Chamamos "redações virtuais" o espaço social de organização do trabalho do jornalista em que a rotina de produção é ordenada, debatida e concretizada por mais de três pessoas ${ }^{51}$ com objetivo de elaborar a matéria jornalística no espaço virtual das plataformas digitais na internet.

Há níveis diferenciados de participação nesse tipo de redação e isso está relacionado com a natureza do arranjo alternativo. Outra característica importante é a própria divisão de trabalho que pode ser organizada por etapa de produção, como o chat Colaboradores, que serve como porta de entrada para pautas, por assunto, para realização de uma cobertura específica, por Estado ou até mesmo por linguagem (verbal ou verbo-visual).

A importância de estudar o espaço social de trabalho do jornalista se dá ao observamos esse lugar como parte do contexto das mudanças do jornalismo.

A redação é um símbolo, mas também o espaço físico que dá origem à produção de informação. Evoluindo de uma pequena sala no coração da gráfica para um escritório grande e móvel aberto, a redação é uma noção importante que permite aos acadêmicos contemplar as mudanças que transformaram o jornalismo no último século. (LE CAM, 2015, p. 3, com tradução nossa)

Outros arranjos que foram observados por Figaro (2018) também fazem uso de espaços virtuais para executar projetos e outras ações relacionadas à comunicação. No entanto, esses espaços não podem ser considerados uma redação virtual, pois o que define se é uma redação ou não é o objetivo final de produção da matéria jornalística. Um exemplo é o Volt Data Lab, arranjo que presta serviço na área de comunicação com pesquisas, cursos e palestras, levantamento e mineração de dados.

Então, cada um mora em um lugar. A gente não tem um lugar de trabalho. O que acontece é que quando a gente vai fechar um trabalho grande, como foi o caso do [nome de um projeto executado pela agência], a gente pega um coworking e fica uma semana. (Entrevistado do Volt Data Lab, CPCT, 2018)

Dentre os arranjos analisados nesta dissertação, o Opera Mundi utiliza o espaço virtual como redação, porém há também a sua redação fixa, fator que diminui a função da redação virtual no cotidiano do trabalho. Por sua vez, o Outras Palavras já utilizou esse espaço para agregar quem trabalhava home office, mas atualmente todo o fluxo de trabalho é organizado pessoalmente; e o Pressenza, como vimos, é uma agência de notícias com organização

\footnotetext{
${ }^{51}$ Mesmo critério de número de pessoas para configuração de um arranjo presente na pesquisa do CPCT. A diferença é que mesmo os blogs, que têm uma estruturação com mais de três pessoas e a intencionalidade de produzir material jornalístico, também têm as suas próprias redações virtuais (como é o caso do Brasil 247, Diário do Centro do Mundo, Conversa Afiada, entre outros).
} 
mundial em que os representantes dos países participantes sistematizam o trabalho na redação virtual, porém no Brasil eles atuam também na sede fixa.

O que podemos aferir é a importância do contato presencial para o desenvolvimento do próprio jornalismo. Quanto mais precarizada for a relação de trabalho, maior a necessidade e dependência de tecnologia para organizá-lo.

Contudo, mesmo em cenários de difícil estruturação financeira desses arranjos, a reação ao estranhamento no trabalho reflete em práticas inovadoras para organizar e difundir a atividade jornalística. A liberdade de produção é um dos atributos que impulsiona essa renovação.

Vejamos como é o fluxo de trabalho no Jornalistas Livres:

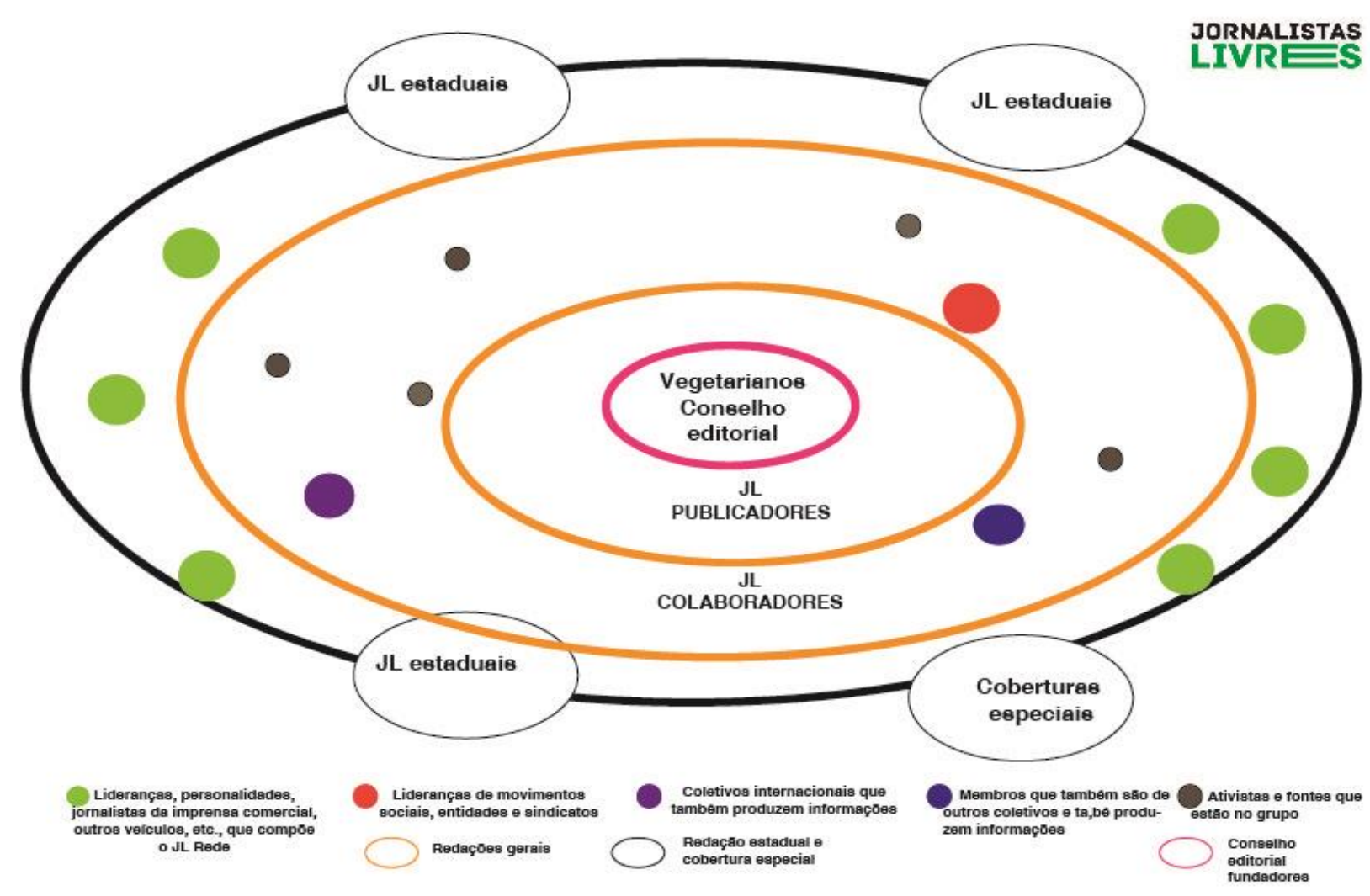

Figura 14 - Fluxo das relações de comunicação e trabalho - Fonte: A autora (2019)

De acordo com a entrevistada Mônica Galvão, a organização é circuncêntrica e acrescentamos também a transversalidade, porque as mesmas pessoas participam de diferentes grupos dentre os 80 existentes do arranjo, entre os quais os seguintes são determinantes para estruturação orgânica: 
-Vegetarianos: o nome é estranho, mas é a secretaria-executiva e o espaço de fundadores e membros mais ativos do coletivo que serve para tomar medidas executivas e administrativas.

Nesse ponto há uma contradição importante de ser pontuada. Em que pese ser o Jornalistas Livres o mais aberto à pesquisa que realizamos, esse espaço - o Vegetarianos - de decisão do coletivo não é claro em sua política de estruturação. Nem todos os membros do próprio arranjo sabem da existência desse espaço de decisões. Mesmo sendo chamada de discussões práticas é importante dar visibilidade, ciência e consciência para os ativistas sobre a existência de fórum decisório. É uma espécie de secretaria operativa trazida pelos Ninjas. Foram eles que criaram, quer dizer, “eles já faziam assim antes”. Eram as pessoas que mexiam com a página.

Não é clara a existência desse grupo para os Jornalistas Livres, mas não precisa ser. Qualquer um que quiser criar um grupo como esse, cria. O lance é que nós somos os administradores da página, somos as pessoas que cuidam da página. (...) O Vegetarianos é uma instância do JL. É uma forma de preservação da página. Não é um núcleo organizativo. (Cláudia Abraão, 2018)

- Publicadores: grupo de pessoas que tem a senha dos sites de redes sociais e/ou do site, responsáveis pela edição, revisão e realização da postagem feita pelo próprio grupo, encaminhada por outro chat ou fonte que compõe a sua rede. Esse é o espaço em que frequentemente acontecem os debates sobre o jornalismo e a estrutura principal da organização do coletivo. Também é o local em que as pautas são aprovadas por no mínimo três pessoas que queiram opinar sobre a publicação ou não do material. O critério é estar online no momento de decisão e intervir na discussão. Podemos aproximar a função do publicador com a de editor, que faz todo o processo de construção de pauta desde a chegada na redação até a publicação e distribuição. No início da nossa pesquisa participaram 58 pessoas, dessas apenas uma se desvencilhou do coletivo após uma discussão sobre jornalismo. De acordo com o manual que orienta as postagens no site e redes, é esse espaço destinado à aprovação da pauta.

\footnotetext{
Antes de qualquer publicação devemos compartilhá-la com os colegas nos chats do Telegram. Hoje temos o chat Publicadores como a porta de debate sobre as matérias que vamos publicar ou não. Não nos envergonhamos de pedir opiniões, perguntar, provocar. Em jornalismo, não há pergunta ruim. Há respostas ruins. A parte mais legal de fazer jornalismo em rede é compartilhar experiências e saberes. A rede sempre vai nos ajudar. (Manual de postagem do JL)
}

- Colaboradores: é um espaço de colaboração em que participam as fontes e os publicadores (para encaminhar a pauta). É uma espécie de grande pauteiro e da seção da carta ao leitor onde o público interage com a produção jornalística. Participam 156 pessoas entre elas 
jornalistas, lideranças sociais, jurídicas, políticas e acadêmicas que quando são movidas por um interesse individual ou coletivo sugerem a pauta.

Tem grupos por temas, por lugar, por cidades...São vários grupos, têm grupos de questão de gênero, de movimento de moradia. São grupos que são grupos por temas, são grupos que são por região, tem alguns da região Campinas, outros de São Paulo, de Uberlândia. Tem os grupos que são por cidade, por estado, país. São muitos grupos de colaboradores. (Cláudia Abraão, 2018)

- Coberturas especiais: é o espaço onde conflui os outros grupos e no qual todos os membros da cobertura postam os materiais, fotos, textos, vídeos, organização da entrada ao vivo etc. Este grupo é destinado os participantes da cobertura, desde a fonte, até o repórter e os responsáveis pela base ${ }^{52}$ e por pessoas interessadas em reproduzir a produção jornalística dos Jornalistas Livres em páginas, perfis ou sites da mídia alternativa. Nas coberturas especiais o volume de material é intenso, por isso o trabalho de distribuição também é fundamental e torna mais ágil ter os "distribuidores" no mesmo grupo que organiza a matéria.

- Chats estaduais: são as redações estaduais que fazem a cobertura dos Estados. Atualmente existem em 11 Estados também participantes das coberturas especiais e no grupo de colaboração.

- Chats por linguagem: espaço que organiza as especificações técnicas da área de comunicação: foto, charge, design, texto, vídeo e rádio (a experiência em rádio é recente e feita junto com um coletivo da periferia de São Paulo).

- Editorias: Parte da redação que atua somente em uma editoria. Por exemplo, Internacional, que agrega brasileiros que estão no exterior e que costumam contribuir com pautas.

Como podemos perceber, assim como na redação física, a virtual também é composta por um sistema de relações sociais determinadas pela organização do trabalho.

No caso do Jornalistas Livres, um espaço importante é o chat Publicadores como local para o debate sobre o jornalismo. É onde há o maior fluxo de mensagens (milhares), o que nos desafiou a usar filtros de pesquisa dentro da própria redação para sistematizar alguns debates.

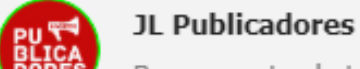

Buscar neste chat

Figura 15 - Reprodução do Telegram

52 Como já falamos anteriormente, fazer base, basear ou ser responsável pela base é fazer as postagens e organização do fluxo de informação entre todas as redes e sites. 
O debate sobre o próprio método é evidenciado numa das discussões dentro do grupo:

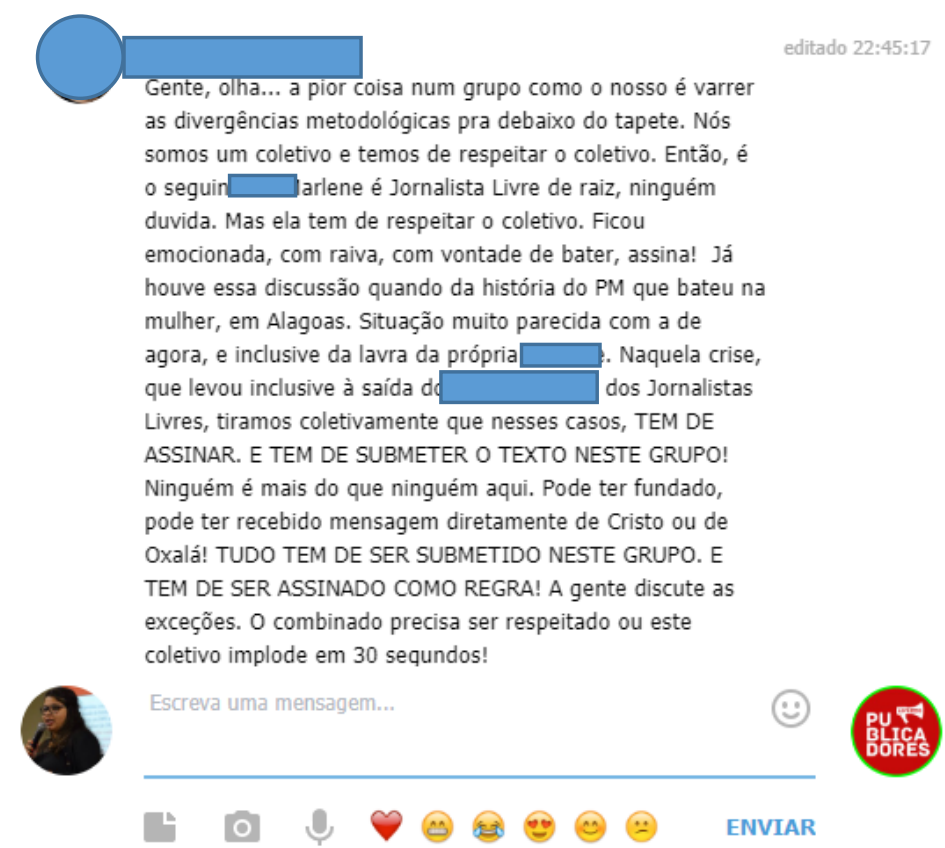

Figura 16 - Print 1 da redação virtual - Fonte: A autora (2019)

Através dessa imagem, temos uma série de informações como o horário da edição do comentário, como se expressam os conflitos de ideias, as características do que é a elaboração coletiva a diferenciando da individual, a metodologia da publicação. O contexto é uma discussão levantada sobre qual tipo de jornalismo está sendo feito pelo coletivo. O debate foi iniciado por um membro que problematizou o uso do adjetivo "asqueroso".

O texto que publicamos, "O comportamento violento do major André Dias em Alagoas", acompanhado do vídeo, se refere ao major com os seguintes termos: "Esse nojento asqueroso aí é o major André Dias, subcomandante do $4^{\circ}$ Batalhão da PM de Alagoas. Ele estava bravo com um suposto barulho em frente à casa dele uma festa de noivado que nem som ligado tinha. "Sou contrário a esse tipo de linguagem que, entendo, nunca foi usada em nossas matérias. (Michel Andrew, 2018)

O jornalista continua dizendo que tem três razões principais: "Essa linguagem é desnecessária, representa uma mudança editorial e impõe riscos."

A discussão aconteceu na redação de Publicadores e teve a participação de outros participantes. O mesmo aconteceu no caso do assassino em série que invadiu uma escola em Suzano, na Grande São Paulo, e matou nove pessoas, em abril de 2019. Uma jornalista do grupo recebeu o vídeo da câmera da escola que gravou o momento da chegada dos assassinos e como eles agiram. A questão levantada foi se o vídeo merecia ser publicado ou não. 
Turma, vou subir o vídeo aqui. Não pra publicar, mas pra gente

discutir. Não pode sair daqui.

Figura 17 - Print 2 da redação virtual Fonte: A autora (2019)

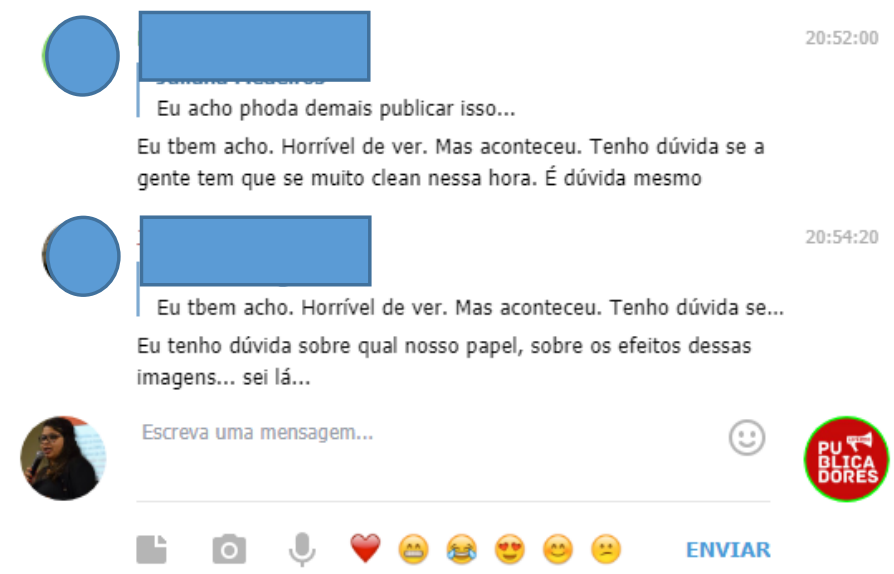

Figura 18 Print 3 da redação virtual. Fonte: A autora (2019)

Assim como essa questão colocada em debate, o fato de ter como método a aprovação de, pelo menos, três pessoas do grupo para fazerem as postagens provoca o debate sobre os limites do jornalismo e o processo coletivo de decisão.

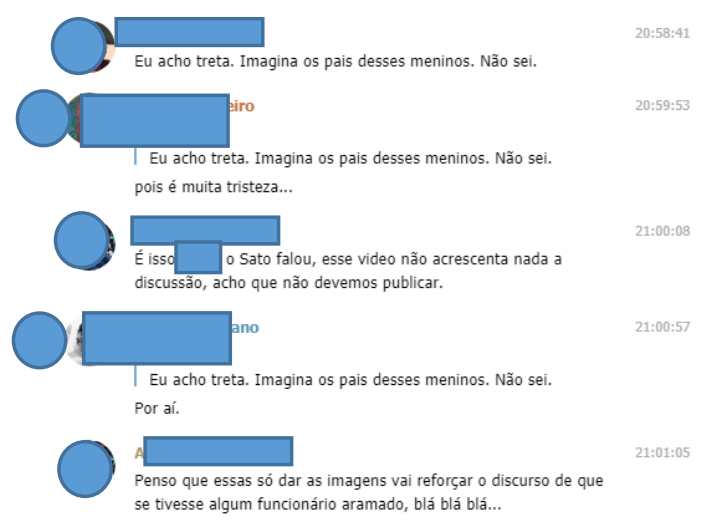

Figura 19 - Print 4 da redação virtual - Fonte: A autora (2019)

Mais uma vez reforçamos que só foi possível capturar essas discussões sobre o trabalho jornalístico com a nossa observação prolongada na redação virtual. Outros temas fazem parte do cotidiano da prática jornalística como a preparação das pautas, discussões sobre a cobertura específica de segmentos como a cobertura das atividades do movimento negro ou o conteúdo de uma charge que continha o discurso homofóbico, e a vigilância com o próprio conteúdo elaborado pela redação. 
Foi esse o caso de uma postagem que falava do envolvimento de Jair Bolsonaro com o motorista Queiroz em um possível caso de corrupção. A postagem foi comentada no blog da revista Veja e chamou a atenção dos jornalistas sobre o seu erro de apuração.

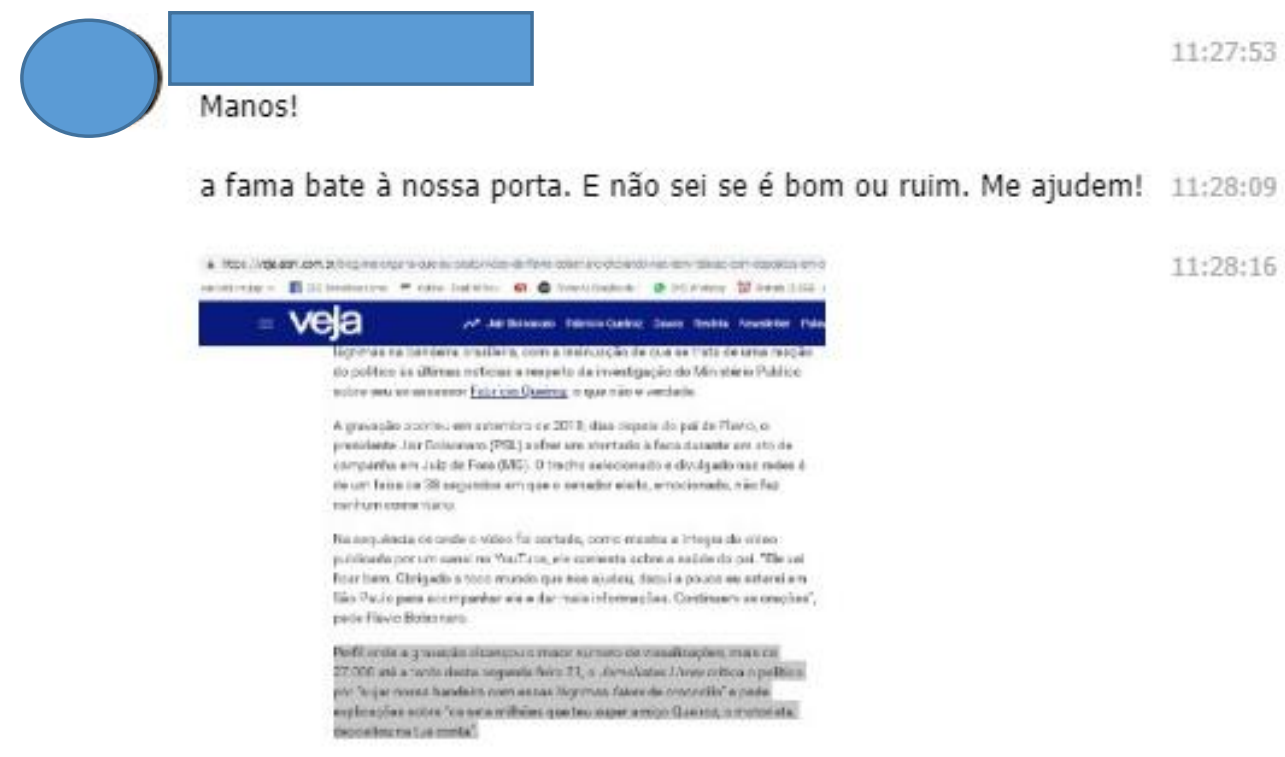

Figura 20 - Print 5 da redação virtual Fonte: A autora (2019)

"A fama" de sair na revista Veja logo é dissolvida com a interpretação da matéria por um dos jornalistas que se preocupa com a fala de canal de notícias falsas, como podemos observar na imagem.

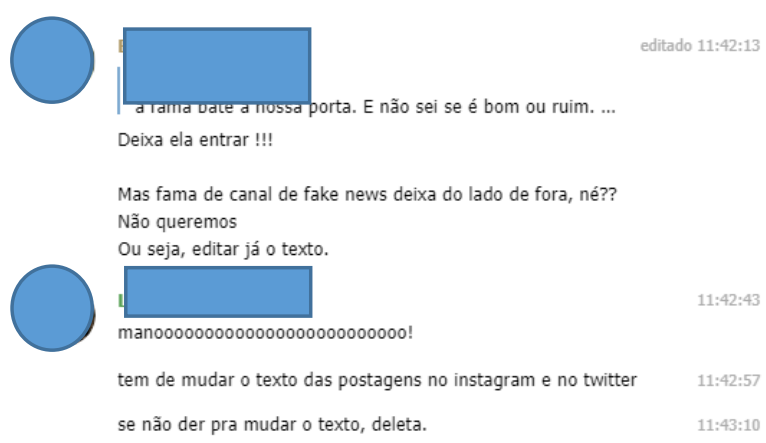

Figura 21 - Print 6 da redação virtual - Fonte: A autora (2019)

Nesse caso, a medida adotada foi apagar a postagem e publicar uma nota de correção, mas Mônica Galvão reforça que a reflexão deve ser coletiva. "Pensando bem, vamos retirar tudo! e escrever uma correção. Gente, eu não posso decidir isso sozinha. não fui eu quem postou então, temos de agir coletivamente."

CORREÇÃO NECESSÁRIA:

No dia 20 de janeiro, Jornalistas Livres publicaram vídeo em que Flávio Bolsonaro "chora" e enxuga as lágrimas, em vez de lenço, com a bandeira nacional. Inadvertidamente não checamos de quando seria esse vídeo, que não foi gravado 
após a onda de denúncias que pesam sobre Flávio Bolsonaro, mas dias antes do início do horário eleitoral gratuito, após a facada em seu pai. Erramos. Outro erro (esse constava no texto) foi dizer que o motorista Fabrício Queiroz depositou 7 milhões na conta de Flávio Bolsonaro. O que o Coaf (Conselho de Controle de Atividades Financeiras) detectou foram R $\$ 7$ milhões em movimentações financeiras por parte do motorista Queiroz em três anos — entre 2014 e 2017.

Agradecemos aos internautas que nos ajudaram a perceber o erro e a corrigi-lo.

(Postagem feita no dia 22 de janeiro de 2019)

As medidas de proteção e vigilância também acontecem no grupo Publicadores, espinha dorsal da organização do Jornalistas Livres. Quem publica na página está nos Publicadores, “[...] que é uma maneira de a gente conseguir se cuidar para não errar e todo mundo se cuidar. Erramos pouco porque temos esse sistema de autoproteção que é de aprovar no grupo que tem 58 pessoas [...]", defendeu Maria Filomena.

Podemos averiguar que o debate sobre qual jornalismo o coletivo realiza significa a potencialidade do Jornalistas Livres, porque tem um espaço pulsante e vivo sobre uma área que está em constantes mudanças relacionadas com o avanço das tecnologias de informação e comunicação.

A redação virtual do JL funciona em tempo integral, está sempre aberta e com sugestão de pautas e debates que podem ser iniciados às 3 horas, às 6 horas ou às 23 horas, por exemplo. Há momentos em que as discussões diminuem, mas elas nunca cessam, não têm horário para começar ou encerrar os debates, acontecendo em fluxo contínuo.

No cotidiano, há a prescrição e renormatização da atividade jornalística. A seguir, vamos descrever o processo de pauta, apuração, edição e distribuição.

\begin{tabular}{|l|l|}
\hline Rotina de produção & Descrição \\
\hline Pauta & $\begin{array}{l}\text { Reuniões abertas (Já foi semanal - toda } \\
\text { terça-feira, às 20h, mas não tem mais a } \\
\text { data fixa) } \\
\text { Debate no sistema de redação - Chats } \\
\text { variados }\end{array}$ \\
$\begin{array}{l}\text { Leitores enviam pautas, informações ou } \\
\text { matérias produzidas pela caixa de } \\
\text { mensagem das redes sociais }\end{array}$ \\
$\begin{array}{l}\text { Fontes externas } \\
\text { Monitoramento das redes sociais }\end{array}$ \\
\hline Apuração & $\begin{array}{l}\text { Debate no espaço Publicadores. } \\
\text { Checagem da informação e definição da }\end{array}$ \\
\hline
\end{tabular}




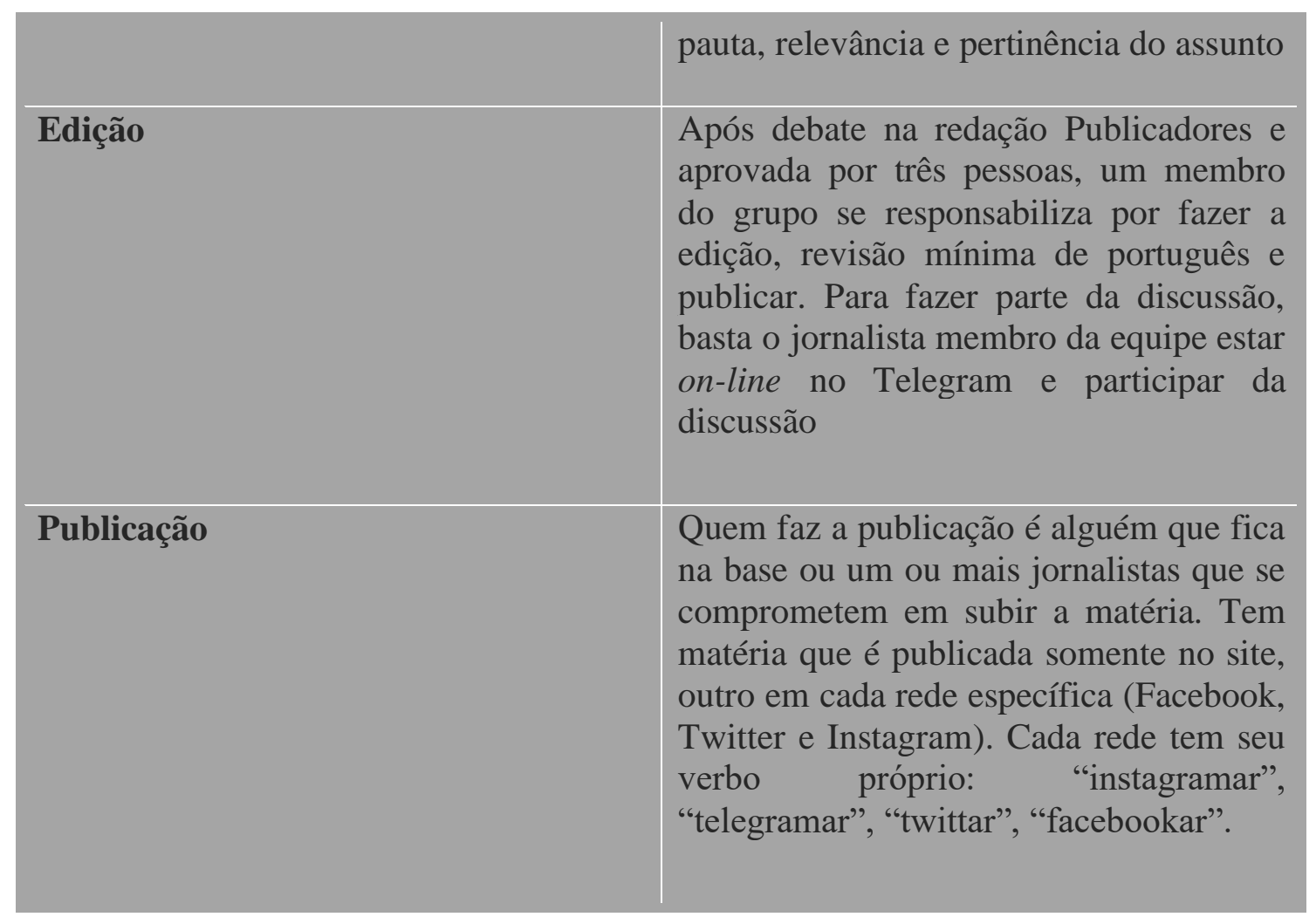

Tabela 4 - Caminho da produção da matéria jornalística

A redação virtual é o espaço de social de organização e controle do trabalho, mas também local onde se dão as inovações das práticas jornalísticas. Por se apresentar como um novo lugar que pode ser articulado ou não com a redação física, o ambiente da redação física é reconfigurado com novas atribuições e papéis na redação virtual. A redação para nós se constitui em espaço e tempo nos quais se operam as ações e decisões sobre o trabalho. É ela a instituinte do cronotopo (BAKHTIN, 2018) que conforma a narrativa jornalística, ao mesmo tempo em que é a porta de entrada para analisar o gênero com a respectiva orientação de espaço e tempo e as condições sociais específicas, sendo o centro o cronotopo o centro de organização dos acontecimentos espaço-temporais.

Chamaremos de cronotopo (que significa "tempo-espaço") a interligação essencial das relações de espaço e tempo como foram artisticamente assimiladas na literatura. Esse termo é empregado com base na teoria da relatividade (Einstein). [...] Importamos messe termo a expressão de inseparabilidade do espaço e do tempo (o tempo como a quarta dimensão do espaço). (BAKHTIN, 2018, p. 11)

As reuniões de pauta são presenciais ou à distância no próprio chat. Nos momentos presenciais a intenção é de mobilizar o máximo de pessoas possíveis que podem contribuir com a elaboração das matérias. Como vemos na imagem a seguir. 


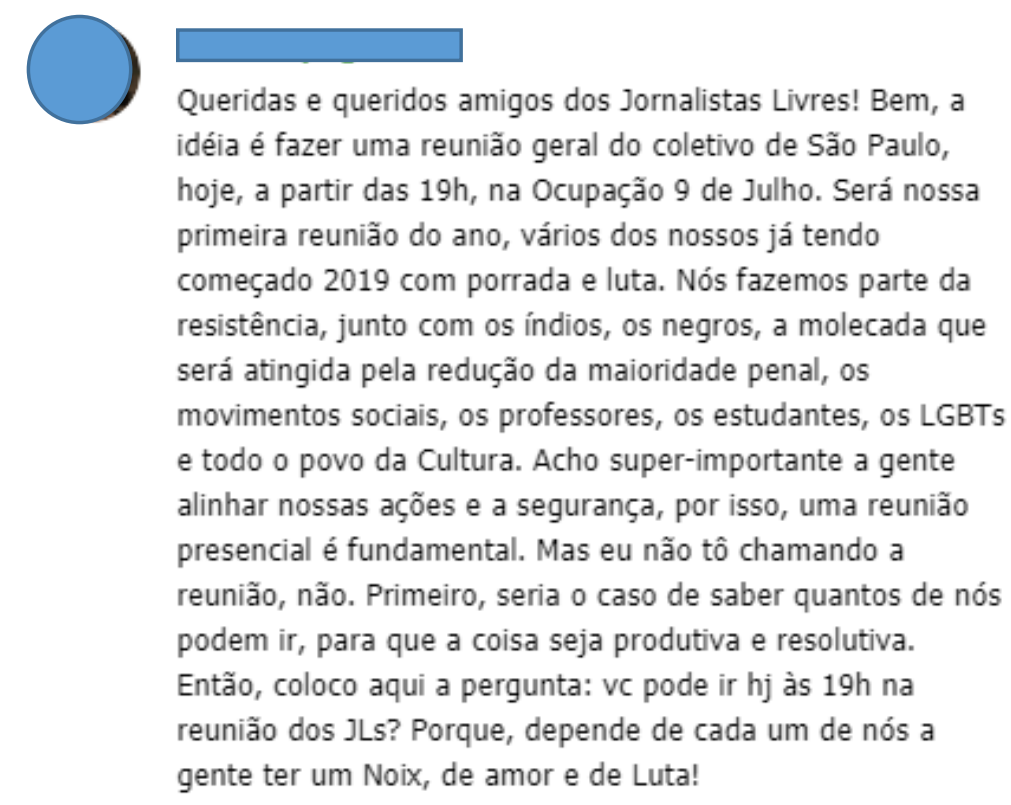

Queridas e queridos amigos dos Jornalistas Livres! Bem, a idéia é fazer uma reunião geral do coletivo de São Paulo, hoje, a partir das 19h, na Ocupação 9 de Julho. Será nossa primeira reunião do ano, vários dos nossos já tendo começado 2019 com porrada e luta. Nós fazemos parte da resistência, junto com os índios, os negros, a molecada que será atingida pela redução da maioridade penal, os movimentos sociais, os professores, os estudantes, os LGBTs e todo o povo da Cultura. Acho super-importante a gente alinhar nossas ações e a segurança, por isso, uma reunião presencial é fundamental. Mas eu não tô chamando a reunião, não. Primeiro, seria o caso de saber quantos de nós podem ir, para que a coisa seja produtiva e resolutiva. Então, coloco aqui a pergunta: vc pode ir hj às $19 \mathrm{~h}$ na gente ter um Noix, de amor e de Luta!

Figura 22 -Print 7 da redação virtual. Fonte: A autora (2019)

O texto do chamado traz à tona a seguinte questão: se o trabalho é voluntário e em regime de colaboração, o que faz com que um jornalista trabalhe toda a sua jornada que bem sabemos ser maior que oito horas e ainda buscar um espaço para fazer jornalismo em seu tempo de não trabalho? Analisaremos essa questão no tópico a seguir.

\section{Trabalho como práxis social}

Entre os quatro arranjos analisados nessa dissertação, o JL é o único que não oferece salário (seja através de contratação jurídica ou outra forma) para os jornalistas que atuam no coletivo. As relações de produção estão ancoradas no comprometimento com a organização, mesmo ao existir casos de participantes interessados em apenas divulgar a sua pauta. Essa é uma discussão frequente entre os seus membros e foi assunto no último encontro organizativo nacional.

Maria Filomena (2018) defende que não ter ninguém recebendo por esse trabalho representa uma fraqueza e uma potencialidade. "A pessoa não está fazendo o trabalho dela para alguém receber alguma coisa. Ninguém ganha dinheiro com os JL. Isso muda muito a relação."

O tema trabalho é tratado de diferentes formas no seio do coletivo a ponto de podermos vislumbrar o que Antunes chama de "pêndulo do trabalho".53 "Se a vida é

\footnotetext{
${ }^{53}$ Informação coletada em sala de aula na disciplina Sociologia do Trabalho I, na Unicamp.
} 
impensável sem o trabalho humano e social - ele é vital e emancipador. Por outro lado, se a vida for só trabalho, ele pode ser um martírio alienante." (informação verbal) ${ }^{54}$

Como mensurar o impacto da naturalização da invisibilidade do valor do trabalho na cadeia produtiva? Por que a discussão sobre o valor do trabalho é um tensionamento constante para o Jornalistas Livres?

Até agora, os membros do coletivo não conseguiram definir uma linha de atuação para essa questão. Há unidade entre as entrevistadas de ser uma experiência jornalista baseada na doação do trabalho representa o principal atributo do arranjo.

Ao lado dessa questão, o critério de quem seria ou não remunerado no arranjo, as formas de seleção de perfil e remuneração é a grande dúvida das entrevistadas. Mônica Galvão (2018) indaga: “Como faz para remunerar o cara aqui de São Paulo e o cara do Ceará? Ou quem está no Publicadores e está em Lisboa, trabalhando para caramba. Por que ele não receberia?"

Da mesma forma, Maria Filomena levanta a questão sobre a natureza da organização:

[...] se a gente começar a remunerar as pessoas, talvez funcionaria mais, mas será que a gente teria tanta força como a gente tem hoje? A impressão é que assim que o dinheiro entra, a boa vontade sai. Porque eu vou trabalhar de graça, se tem alguém ganhando? Pode gerar esse tipo de raciocínio. (Maria Filomena, 2018)

De um lado, o drama sobre o valor do trabalho para o próprio coletivo e de outro, qual é o valor desse trabalho coletivo, voluntário e engajado para as gigantes empresas da internet que lucram com as postagens, matérias, armazenamento de informações, fotos e vídeos, além do tráfego da rede.

Associamo-nos à afirmativa de Ricardo Antunes como aspecto central para se ter uma visão ampliada das “[...] mais distintas modalidades de trabalho presentes no capitalismo contemporâneo vêm - diferente do que foi propugnado nas últimas décadas - ampliando as formas geradoras de valor, ainda que assumindo a forma de não valor [...]" e contribuindo com a circulação do capital e na “[...] reprodução ampliada do capital financeirizado, informacional e digital.” (2018, p. 32-33)

No outro polo do pêndulo está o trabalho como práxis social e como forma de conferir sentido à vida além no tempo de não trabalho.

\footnotetext{
${ }^{54}$ Ricardo Antunes, 2018, informação coletada em sala de aula na disciplina Sociologia do Trabalho I, na Unicamp
} 
É uma troca fundamental. Porque me sinto mais ativa, senão eu vou meio que sumir. Tenho um pouco a sensação de que esse reconhecimento me mantém ativa, na rede, como pessoa. Tem o reconhecimento dentro do contexto de um trabalho coletivo. Além disso tem essa questão da mídia também. Lembro que quando eu trabalhava na Folha. S. Paulo eu era Joana, da Folha. Hoje sou a JL4, JL, JL, JL. (Ana Cláudia da Silva, 2018)

Luckács (2013) apoia-se nos Manuscritos econômico-filosóficos de Marx para explicitar que o trabalho no capitalismo estranhava o trabalhador dos produtos do seu próprio trabalho. O trabalho se transforma em modo de coerção, degradação e desumanização do homem a "[...] ponto de sentir-se livre e ativo somente com as suas funções animais." Para o autor, para combater o estranhamento, “[...] a práxis social real tem prioridade absoluta." (2010, pp. 754-755)

Diferentemente do trabalho de Ana Cláudia na Folha de S. Paulo, no processo não mercantil o jornalista busca avançar a sua consciência individual e coletiva, ampliando a qualidade e a intervenção material na realidade que se busca atuar. Esse contexto e a compreensão da atividade de trabalho, sem a relação mediada por salário, estimulam o posicionamento e os valores do jornalista, para além dos objetivos corporativistas, para si e para um bloco social.

A ausência de objetivos mercadológicos de vender a informação como commodities não anula outras trocas nas relações de trabalho. A troca é simbólica, como o status e reconhecimento, por espaço e composição de portfólio, como espaço de vocalizar determinadas pautas em que o colaborador é ao mesmo tempo fonte.

Ainda desse lado do pêndulo está o trabalho como critério para que os participantes do coletivo avancem dentro dos grupos e evoluam na organização. "São círculos de confiança adquirida pelo trabalho. É só o trabalho que credencia você para mudar de círculo. Então, você tem que ser orgânico, mais orgânico, mais orgânico ainda e assim vai”, apresentou Mônica Galvão (2018).

O processo de militância, atuação por uma causa, também é visto como trabalho. "Militância e trabalho são as mesmas coisas hoje em dia", afirma Maria Filomena (2018). Da mesma forma, Mônica Galvão (2018) conclui que é “[...] uma militância da contra narrativa que significa o seguinte: leva a sua vida, arruma um emprego, nas horas vagas você trabalha com os JL. Ou então, se você tiver um emprego que tiver uma sinergia com os JL, ótimo, uma coisa junta a outra." 
Outro fator é o engajamento como espírito do toytismo que influi em toda cadeia de produção. No livro $O$ sistema Toyota de produção: além da produção em larga escala, Taiichi Ohno aponta a filosofia que sustenta o modo de produção flexível. Ele utiliza expressões do tipo “[...] os esportes nos dão muitas indicações úteis [...]” para se referir sobre a importância do trabalho coletivo e assim justificar. "Na manufatura a equipe de produção que tenha dominado o sistema just-in-time é exatamente como um time de beisebol que joga bem em equipe." (OHNO, 1997, p. 97)

Não existe time esportivo sem a disposição para disputar o jogo, da mesma forma que não há toytismo sem o sequestro da subjetividade do trabalhador, sem aproveitar o engajamento no trabalho.

O toytismo captura e mobiliza a subjetividade, isto é, o corpo e a mente tornam-se objetos de apropriação do capital. “A imprescindibilidade do 'engajamento' moral-intelectual dos operários e empregados na produção do capital "que implica a necessidade da "captura" da subjetividade do trabalho vivo pelos ditames da produção de mercadorias." (ALVES, 2011, p. 46)

Com as novas tecnologias, o papel dos dispositivos, como o celular, é intensificado nesse processo de sequestro da subjetividade pelo modo de produção. Todas as entrevistadas do Jornalistas Livres disseram que veem a redação virtual por meio do celular incontáveis vezes por dia.

A entrevistada pelo CPCT afirmou que "[...] se não desligar o celular não para de trabalhar [...]" e que faz isso de qualquer lugar. Ana Cláudia corrobora a intensificação do trabalho. "O negócio da redação virtual é uma merda, né? Porque é assim, quando estou no banheiro tenho vontade de ver um vídeo, de editar o vídeo. Já saio correndo desesperada para fazer alguma coisa." (Ana Cláudia da Silva, 2018)

Assim como no modo de produção flexível não há separação entre tempo de não trabalho e de trabalho. A jornada de trabalho não foi diluída alternando-se entre tempo de vida e de trabalho, mas sim se alargou intensificando o trabalho do jornalista.

David Harvey pontua que há múltiplas “[...] qualidades objetivas no espaço e tempo que exprimem seus papéis enquanto práticas humanas. Essas práticas são criadas através de processos materiais que servem à reprodução da vida social.” (1992, p. 189) 
Os limites entre tempo de trabalho e tempo de não trabalho são borrados havendo a predominância, como já afirmamos, do tempo de trabalho.

\begin{abstract}
Sob a superfície de ideias do senso comum e aparentemente "naturais" acerca do tempo e do espaço, ocultam-se território de ambiguidade, de contradição e de luta. Os conflitos surgem não apenas de apreciações subjetivas admitidamente diversas, mas porque diferentes qualidades materiais objetivas do tempo e do espaço são consideradas relevantes para a vida social em diferentes situações. Importantes batalhas também ocorrem nos domínios da teoria, bem como da prática, científica, social e estética. (HARVEY, 1992, p. 190)
\end{abstract}

Para Pietro Basso (2018, p. 333), o “[...] núcleo de todo o problema do tempo e do tempo de trabalho na sociedade atual é que o tempo é uma mercadoria, objeto de compra e venda em dinheiro." A discussão feita pelo autor é sobre as jornadas de trabalho e o significado do trabalho não remunerado dentro do quadro de ser o trabalho possuidor de valor ao mesmo tempo em que também é a fonte de criação de valor.

A divisão já foi clara no final do século XX, embora o tempo de não trabalho ser revertido para consumo, sendo outra forma de gerar valor. "Hoje o trabalho, com os tempos estendidos, consegue extrair valor em tempo integral." (informação verbal) ${ }^{55}$.

O que nos faz refletir é o fato de, ao falar sobre trabalho e militância, esse mesmo trabalho é repleto de novas significações para a sobrevivência cotidiana do profissional de comunicação em uma relação não mediada pelo salário. Há outras mediações, algumas já citadas anteriormente, como o reconhecimento e o prestígio, citado por Ana Cláudia da Silva, como capitais simbólicos que agregam à percepção do jornalista questões de outro tipo além das que fazem parte do conhecimento do cotidiano ${ }^{56}$ do trabalho de uma grande corporação de mídia ou nas miríades de agências de comunicação e assessorias de imprensas que tratam da mesma forma o seu quadro funcional.

O trabalho e a atuação por uma causa se confundem pela complexidade e impacto do próprio mundo do trabalho. As mediações aqui não são feitas porque uma parte detém os meios de produção, mas com outras regras que não são as mesmas da lógica da monetização mercantil da matéria jornalística. É um trabalho com sentido "dialógico e democratizador" na arena de forças que disputam o rumo civilizacional que faz parte de uma concepção de vida

\footnotetext{
${ }^{55}$ Trecho de fala em sala de aula da Profa. Roseli Fígaro, 2018.

56 Assim como Peitro Basso (2018. p. 191) também não vamos entrar no debate acerca desse cotidiano. De acordo com Berger apud Basso: "A realidade mais profunda é aquela da vida cotidiana [...]"; "[...] a nossa experiência de sociedade é, sobretudo, uma experiência de sociedade e, em grande parte uma experiência de rotina [...]"; e ainda "[...] a análise do caráter de rotina necessariamente de rotina, implica uma consequência muito importante $[\ldots]$ ", qual seja, que cada um "[...] constrói sua própria experiência com os outros [...].'
} 
ou mesmo de um ponto convergente sobre determinados assuntos, como aquelas pessoas que enviam a sua matéria pronta para ser veiculada na cobertura do Jornalistas Livres.

Outro fator importante é a desnaturalização da precarização do trabalho. Se a jornada do tempo de trabalho fosse reduzida, por exemplo, as condições de militância ou de doação da força de trabalho seriam outras.

É fundamental a reflexão sobre a intensidade do trabalho e quanto essas atividades tomam conta do tempo de "não trabalho", fazendo com que as consequências antissociais, danos à saúde psíquica e física dos jornalistas sejam cada vez mais frequentes, gerando impacto na própria produção de jornalismo.

Após a nossa observação sobre o Jornalistas Livres, podemos inferir que é o trabalho que confere valor, até por ser como Marx (2017a) a única mercadoria diferenciada que gera mais valor. Ao tornar o trabalho aparente, bem como a "mercadoria" - notícia agregada ao conhecimento - ficará mais nítido o valor de troca da produção jornalística no arranjo, além do valor de uso já conferido.

De fato, não é uma atribuição fácil estabelecer o valor do trabalho sem desconfigurar o que é conhecido como militância. A figura do militante está presente em vários momentos históricos e dos dois lados da luta de classes em momentos mais acirrados de rupturas ou não, é sempre visto como chamou Guevara (2010, p. 129) como “[...] um orientador [...], um trabalhador incansável que tudo entrega a seu povo, um trabalhador sofrido que entrega suas horas de descanso [...]"

Essa abordagem do trabalho militante não exclui a possibilidade de o seu trabalho ser pago para suprir as suas necessidades de vida ou para viabilizar a elaboração de uma matéria jornalística. Dar essas condições ao jornalista, principalmente ao novo jornalista que não teve as benesses de um cargo de chefia nos "tempos de ouro" das corporações de mídia ou herança, é valorizar o jornalismo e o trabalhador da notícia.

\section{O jornalismo realizado pelo Jornalistas Livres}

Seria uma redundância apenas afirmar o quanto as relações de comunicação e trabalho intervêm na produção da matéria jornalística. A importância de o profissional de comunicação ter condições para realizar o seu trabalho, ter tempo para se dedicar, assimilar as significações que o trabalho contribui para a leitura do mundo e da vida, refletem diretamente no jornalismo, no papel que ele pode cumprir para a sociedade. 
No Jornalistas Livres o tema é a própria razão de existência visto que o coletivo se coloca em defesa do jornalismo com a oposição aos "[...] estratagemas da tradicional indústria jornalística (multi)nacional, que, antidemocrática por natureza, despreza o espírito jornalístico em favor de mal disfarçados interesses empresariais e ideológicos, comerciais e privados, corporativos e corporativistas". O manifesto de criação do Jornalistas Livres acrescenta:

(...) produzimos REPORTAGEM. Lamentamos o confinamento a que a indústria midiática relegou o mais nobre dos gêneros jornalísticos e trabalhamos para reduzir o abismo de desequilíbrio. A matéria-prima de nossas reportagens é HUMANA. Almejamos um jornalismo humano, humanizado e humanizador, ancorado principalmente em personagens da vida real (não só em estatísticas), na frondosa diversidade da vida dentro da floresta (não à distância robocop das tomadas aéreas panorâmicas), na fortuna das histórias (não dos cifrões). (Manifesto de lançamento dos Jornalistas Livres, 2015)

A partir do trecho, podemos identificar a crítica à "indústria midiática", ao rebaixamento do jornalismo e o oposto disso, ou seja, “[...] o jornalismo humano, humanizado e humanizador, ancorado principalmente em personagens da vida real (não só em estatística)" como saída para libertar o confinamento do mais "nobre dos gêneros jornalísticos" - a reportagem.

No Manifesto há outras menções à concepção de jornalismo como "afirmativo", "fonte de conhecimento transformador", cujo objeto de documentação, reportagem e interpretação recebem a interferência dos jornalistas.

Para Nilson Lage (2002, p. 9), o êxito da reportagem é “[...] essencialmente de quem executa."

O trabalho de reportagem não é apenas o de seguir um roteiro de apuração e apresentar um texto correto. Como qualquer projeto de pesquisa, envolve imaginação, insight: a partir dos dados e indicações contidos na pauta, a busca do ângulo (às vezes apenas sugerido ou nem isso) que permita revelar uma realidade, a descoberta de aspectos das coisas que poderiam passar despercebidos.

No cotidiano e na prática, a dificuldade de realização da reportagem se impõe devido à falta de estrutura, mas também quanto ao método de organização de trabalho. No grupo, há a problematização quando há "mais memes do que reportagem" (Entrevistada CPCT, 2018) A pauta nasce da necessidade de falar determinados assuntos, mas mesmo com "[...] jornalistas experientes, não tem um método para tocar as coisas [...]" e fazer uma "reportagem por dia".

Não há fôlego e organização para produzir as reportagens que Mônica Galvão (2018) apresentou em depoimento ser o "[...] gênero mais nobre do jornalismo, que separa a verdade 
da mentira. "Muitas pautas que carecem de mais tempo de preparação, apuração e produção não são concretizadas, como acompanhamos nas reuniões e depois a sua efetivação.

A pauta chega de diversas formas. Uma delas é através de uma rede de colaboradores individuais, movimentos, entidades, veículos de mídia ou coletivos. Esse material pode ser um artigo, matéria noticiosa, vídeo ao vivo, fotografias, charges, reportagem e notas que são distribuídas nas redes sociais. O nosso recorte foi o jornalismo presente no site do arranjo entre os dias 1e 7 de janeiro ${ }^{57}$, na primeira semana de gestão do governo de Jair Bolsonaro.

Nesse período foram publicadas notas (de entidades como Anamatra, Anpuh e CMI) ${ }^{58}$, artigos (de um pastor de Minas Gerais e uma professora da Escola de Comunicações e Artes), três reportagens (duas sobre a posse de Bolsonaro e sobre cultura, matérias notícias copiadas de outros sites (como o da APIB - Articulação dos Povos Indígenas do Brasil). As pautas discutidas na redação foram planejadas sob a ótica do coletivo.

A contribuição da rede de colaboradores tem outros motivos e necessidades que não passam pelo crivo ou acompanhamento de algum editor ou jornalista do arranjo no desenvolvimento da pauta, quando a matéria chega ela já está pronta ou carecendo de alguns ajustes.

Dessa forma, esse jornalismo é atravessado por múltiplos vieses e objetivos que não são apenas os declarados no Manifesto ou discutidos entre o coletivo, ao mesmo tempo que é um jornalismo vivo, pulsante e é debatido a todo momento na redação virtual. O tensionamento onipresente da discussão do jornalismo e a sua prática contribui para plasmar um sentido ético para a profissão ao mesmo tempo gerador de conhecimento. Esse processo é tão ou mais importante do que afirmar que o jornalismo "verdadeiro" é aquele fundado na reportagem e apoiado na deontologia clássica do jornalismo, como apontado no Manual da Folha de S. Paulo, referência para três das quatro pessoas entrevistadas.

Dentre a produção da rede de colaboradores há um trabalho de curadoria do que será publicado, feito pelos Publicadores do grupo. A pergunta "por que dar" a matéria e onde ela se relaciona com o Jornalistas Livres é feita no coletivo. Como há a questão da falta de recursos humanos para a produção constante do arranjo, esses materiais que chegam prontos têm possibilidades de serem aproveitados.

\footnotetext{
${ }^{57}$ Recorte cuja intenção é pegar os primeiros dias de um novo ciclo político brasileiro.

${ }^{58}$ Anamatra (Associação Nacional dos Magistrados da Justiça do Trabalho). Anpuh (Associação Nacional de História.
} 
Em quase três anos, a MediaQuatro produziu cerca de 50 matérias especiais para os Jornalistas Livres, quase todas com vídeos, sem contar a infinidade de postagens (com ou sem vídeos) realizadas apenas para o Facebook. (Participação de coletivo). Contribuímos, ainda, com edição e publicação de um sem-número de outras matérias realizadas por parceiros e colaboradores eventuais. Entre as reportagens de maior impacto estão a cobertura continuada sobre a então maior ocupação urbana do Brasil, com 2.350 famílias, a Élisson Prieto, antiga Glória, em Uberlândia. (SOUZA; SÁ, 2018, p. 1)

Assim como o MediaQuatro, outros coletivos e veículos contribuem com o Jornalistas Livres com a sua forma de fazer jornalismo. Com o crescimento do público leitor, ao mesmo tempo, postar nas mídias do JL significa dar visibilidade para as suas pautas. É assim que o Jornal Empoderado, que tem o recorte de raça, combate ao racismo e promove a igualdade racial, utiliza o espaço de colaboração dentro do arranjo.

$\mathrm{Na}$ busca por ordenamento mínimo para as contribuições, há uma cartilha de publicações, material sobre cobertura de manifestações e um guia básico de português para auxiliar o trabalho daqueles que não têm formação jornalística, como maneira de sistematizar e democratizar o conhecimento. "Guias são um instrumento de popularização das descobertas." (Maria Filomena, 2018)

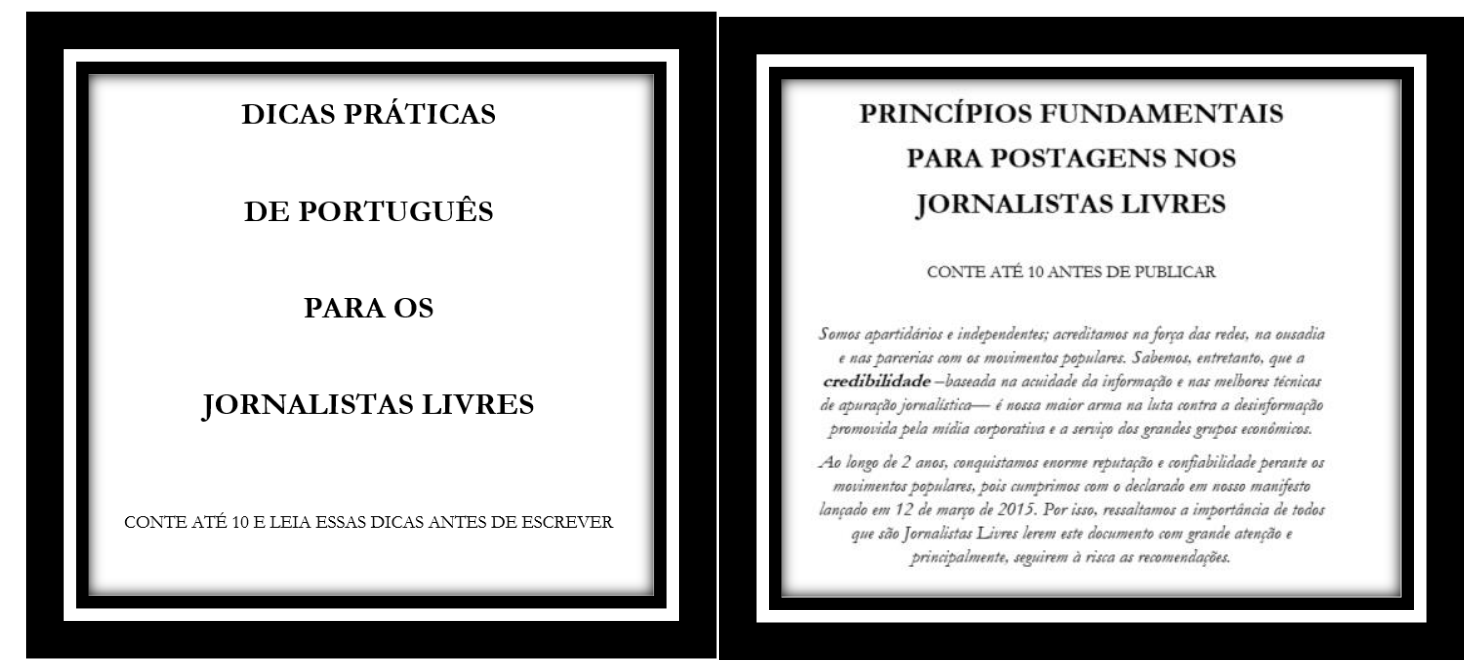

Figuras 10 e 11 - Reprodução arquivo Word dos guias Práticas de Português e Princípios Fundamentais para Postagens nos Jornalistas Livres

O guia de português oferece dicas como uso de vírgula, crase, advérbios, o uso do dicionário etc. Já o guia que trata dos princípios para postagens pede para que o autor verifique as fontes, cheque as informações, construa manchetes que despertem o interesse do leitor, reflete sobre o papel do meme, delineia o caminho da pauta ao pontuar que ela deve 
passar e ser aprovada pelos Publicadores, estimula o autor a questionar sobre o assunto e buscar ajuda quando estiver com alguma dúvida, entre outros assuntos.

Não nos envergonhamos de pedir opiniões, perguntar, provocar. Em jornalismo, não há pergunta ruim. Há respostas ruins. A parte mais legal de fazer jornalismo em rede é compartilhar experiências e saberes. A rede sempre vai nos ajudar. Importante: defendemos a Democracia, mas no campo da Democracia, muitos posicionamentos não são consensuais. Portanto, é necessário deixar bem claro se estamos publicando uma opinião pessoal (artigo assinado) ou um posicionamento de grupo. Ter opinião não é motivo para guerra entre nós. (Princípios Fundamentais para as Postagens nos Jornalistas Livres)

Ademais esses dois "guias", há também o padrão para envio de matérias como podemos ver na figura a seguir: 


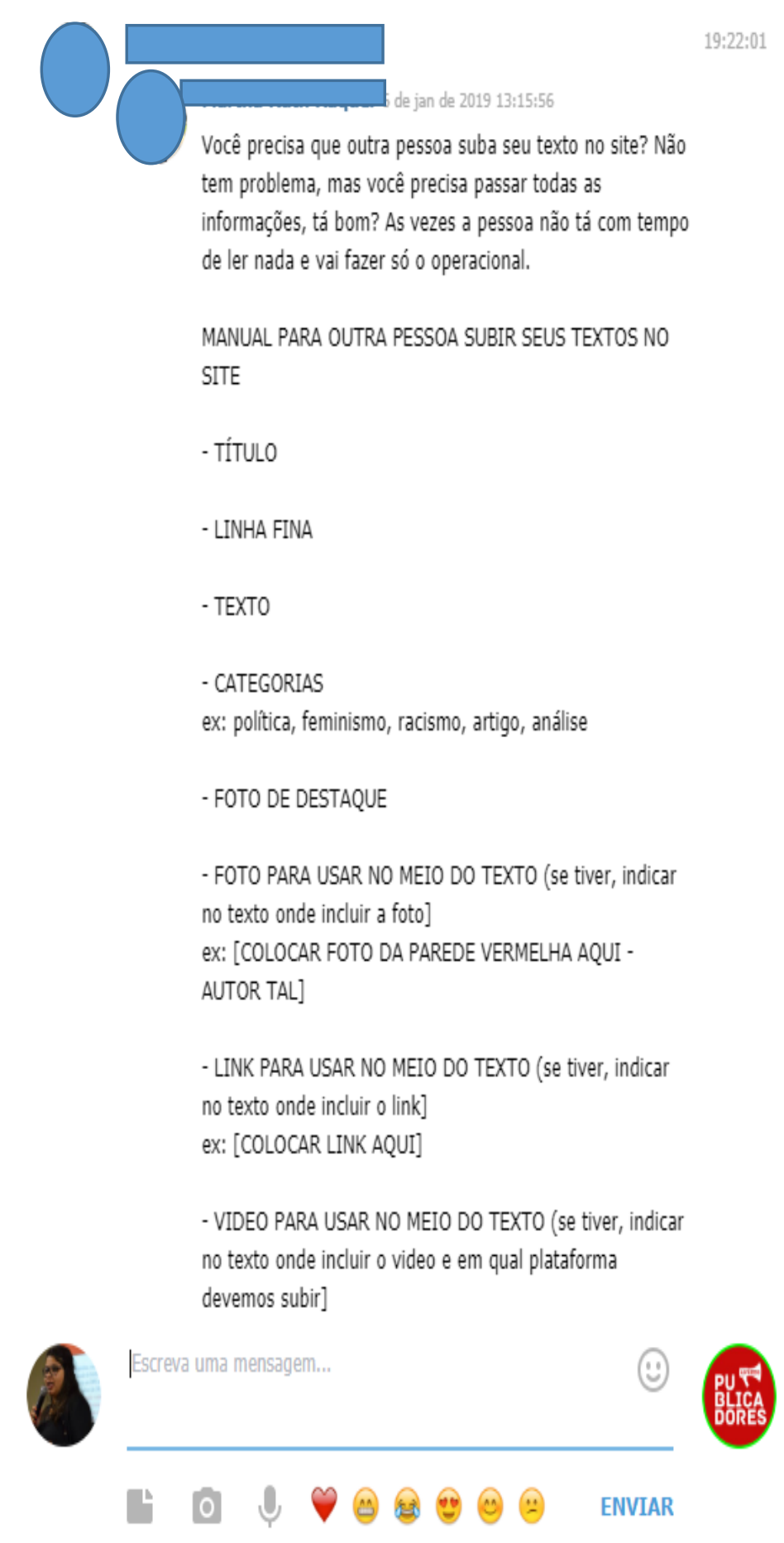

O jornalismo em rede é também chamado de "jornalismo cidadão", "jornalismo colaborativo", "jornalismo código aberto", "jornalismo participativo". As diferenças entre esses termos, de acordo com Foschini e Tadei (2006, p. 19), são nuances. Por exemplo, o participativo ocorre quando há a participação dos leitores e os comentários são incluídos na matéria. Já o colaborativo quando "[...] mais de uma pessoa contribuiu para o resultado da publicação." Segundo os autores, os outros dois termos são caracterizados por:

Jornalismo código aberto - Surgiu para definir um estilo de jornalismo feito em sites wiki, que permitem a qualquer internauta alterar o conteúdo de uma página. 
Também pertencem a esse grupo vídeos, fotos, sons e textos distribuídos na rede com licença para serem alterados e retrabalhados.

Jornalismo grassroots - Refere-se à participação na produção e publicação de conteúdo na web das camadas periféricas da população, aquelas que geralmente não participam das decisões da sociedade. Quando elas passam a divulgar as próprias notícias, causam um feito poderoso no mundo da comunicação. Quem usa esse termo defende a ideia de que o jornalismo cidadão está diretamente relacionado à inclusão dessas camadas no universo criado pelas novas tecnologias de comunicação. (FOSCHINI; TADEI, p. 2006, p. 19)

No Brasil, os coletivos das periferias estão reformulando o conceito de jornalismo cidadão e comunitário, os quais deixam de ser somente a rádio e o jornal do bairro e passam a ser coletivos que buscam refletir e consolidar as identidades das comunidades ao tratar de suas pautas a partir de quem vive os próprios assuntos narrados.

Essas diferenciações acontecem e se complexificam com o desenvolvimento da tecnologia, à medida que permitem ampliar a participação e o manuseio dos meios de produção, conforme falamos em diferentes momentos. Assim, impacta nas formas de fazer jornalismo, ao mesmo tempo em que os meios de produção ficaram mais leves e baratos.

No JL, a produção colaborativa no site é organizada nas editorias de moradia, política, direitos humanos, cultura e educação. ${ }^{59}$ Entre os principais assuntos estão:

Movimentos sociais a gente faz questão de cobrir e, particularmente o movimento de moradia, a pauta de educação é cara para gente, cara mesmo. A questão das drogas também é uma questão cara, especificamente a cracolândia. Tem polícia, vai ter jornalista lá. O Lula que é um assunto importantíssimo, a narrativa do impeachment, a questão de mulheres e do LGBT. Até porque tem muita gente do LGBT e temos muitas mulheres. É uma característica importante onde as mulheres estão em função de destaque que também é uma diferença. A mídia blogueira é muito machista. E de negros, que é um assunto forte, embora a gente não esteja entrando nas tretas intra movimento negro, por exemplo, a disputas entre Emicida e Djamila, é melhor eles discutirem as divergências deles. Tem que falar da luta antiracista. (Mônica Galvão, 2018)

Esses temas estão materializados em nosso recorte nos seguintes materiais jornalísticos:

\begin{tabular}{|l|l|l|l|}
\hline Data $^{60}$ & Editoria & Título & Descrição \\
\hline 2 de janeiro & Política & $\begin{array}{l}\text { Protestos contra } \\
\text { Bolsonaro em }\end{array}$ & $\begin{array}{l}\text { Notícia escrita } \\
\text { por um membro }\end{array}$ \\
\hline
\end{tabular}

\footnotetext{
${ }^{59}$ Há uma editoria especial de cobertura da Assembleia Legislativa do Estado de São Paulo, a qual não consta data de publicação e por isso não entrou no material coletado.
}

${ }^{60}$ Não houve atualização nos dias 1 e 5 de janeiro. 


\begin{tabular}{|c|c|c|c|}
\hline & & Portugal & do JL \\
\hline 2 de janeiro & Política & $\begin{array}{l}\text { Brasília, posse } \\
\text { de Bolsonaro: a } \\
\text { gente estava lá }\end{array}$ & $\begin{array}{l}\text { Notícia sobre a } \\
\text { posse do atual } \\
\text { presidente }\end{array}$ \\
\hline 2 de janeiro & Política & $\begin{array}{l}\text { Contagem } \\
\text { aberta: tudo de } \\
\text { ruim que } \\
\text { Bolsonaro já fez } \\
\text { na presidência }\end{array}$ & $\begin{array}{l}\text { Reportagem em } \\
\text { constante } \\
\text { atualização, não } \\
\text { assinada, sobre } \\
\text { os principais } \\
\text { fatos do governo } \\
\text { Bolsonaro }\end{array}$ \\
\hline 3 de janeiro & $\begin{array}{l}\text { Direitos } \\
\text { Humanos }\end{array}$ & $\begin{array}{l}\text { Facebook } \\
\text { censura } \\
\text { tradições } \\
\text { milenares }\end{array}$ & $\begin{array}{l}\text { Texto escrito em } \\
\text { primeira pessoa } \\
\text { por Chico } \\
\text { Sant'Anna em } \\
\text { seu blog e } \\
\text { republicado no } \\
\text { site }\end{array}$ \\
\hline 3 de janeiro & Política & $\begin{array}{l}\text { Dezenas de } \\
\text { gabinetes são } \\
\text { invadidos } \\
\text { durante a posse } \\
\text { de Bolsonaro }\end{array}$ & $\begin{array}{l}\text { Notícia } \\
\text { publicada por um } \\
\text { dos membros } \\
\text { para denunciar a } \\
\text { invasão de } \\
\text { gabinetes no } \\
\text { Congresso } \\
\text { Nacional }\end{array}$ \\
\hline 4 de janeiro & Política & $\begin{array}{l}\text { Evangélicos e o } \\
\text { seu caso de amor } \\
\text { com Israel }\end{array}$ & $\begin{array}{l}\text { Artigo de } \\
\text { opinião assinado } \\
\text { por um pastor de } \\
\text { Belo Horizonte }\end{array}$ \\
\hline 4 de janeiro & Política & $\begin{array}{l}\text { Nota à imprensa } \\
\text { da Associação } \\
\text { Nacional dos } \\
\text { Magistrados da } \\
\text { Justiça do } \\
\text { Trabalho }\end{array}$ & $\begin{array}{l}\text { Com um curto } \\
\text { parágrafo que } \\
\text { cumpre o papel } \\
\text { do lead, } \\
\text { publicação na } \\
\text { íntegra da nota } \\
\text { da Anamatra }\end{array}$ \\
\hline 4 de janeiro & Política & $\begin{array}{l}\text { Sobre política, } \\
\text { distração e } \\
\text { destruição }\end{array}$ & $\begin{array}{l}\text { Artigo de um } \\
\text { professor } \\
\text { universitário }\end{array}$ \\
\hline 6 de janeiro & Cultura & $\begin{array}{l}\text { É dia de Santo } \\
\text { Rei no Ceará }\end{array}$ & $\begin{array}{l}\text { Baseada em } \\
\text { informações de } \\
\text { site parceiro } \\
\text { (Reisado Bra) a }\end{array}$ \\
\hline
\end{tabular}




\begin{tabular}{|c|c|c|c|}
\hline & & & $\begin{array}{l}\text { matéria autoral, } \\
\text { assinada por } \\
\text { Jarbas Oliveira, } \\
\text { retrata uma pauta } \\
\text { regional do } \\
\text { Nordeste. }\end{array}$ \\
\hline 6 de janeiro & Política & $\begin{array}{l}\text { Assassinado o } \\
\text { primeiro } \\
\text { trabalhador rural } \\
\text { do governo } \\
\text { Bolsonaro }\end{array}$ & $\begin{array}{l}\text { Notícia assinada } \\
\text { por uma } \\
\text { jornalista do } \\
\text { coletivo sobre a } \\
\text { morte de um } \\
\text { trabalhador sem- } \\
\text { terra nos } \\
\text { primeiros dias do } \\
\text { governo } \\
\text { Bolsonaro }\end{array}$ \\
\hline 6 de janeiro & Política & $\begin{array}{l}\text { Apertem os } \\
\text { cintos: } 2019 \text { deu } \\
\text { a largada! }\end{array}$ & $\begin{array}{l}\text { Artigo de uma } \\
\text { professora } \\
\text { universitária }\end{array}$ \\
\hline 7 de janeiro & Educação & $\begin{array}{l}\text { Pesquisadores se } \\
\text { opõem à política } \\
\text { ideológica para } \\
\text { concessão de } \\
\text { bolsas }\end{array}$ & $\begin{array}{l}\text { Repercute a nota } \\
\text { na coluna do } \\
\text { Ascânio Seleme } \\
\text { e a nota da } \\
\text { ANPUH }\end{array}$ \\
\hline 7 de janeiro & Política & $\begin{array}{l}\text { Nota do Cimi: } \\
\text { Medidas } \\
\text { inconstitucionais } \\
\text { do governo } \\
\text { Bolsonaro } \\
\text { afrontam direitos } \\
\text { indígenas }\end{array}$ & $\begin{array}{l}\text { Repercute a nota } \\
\text { com um } \\
\text { parágrafo de } \\
\text { contextualização }\end{array}$ \\
\hline 7 de janeiro & $\begin{array}{l}\text { Direitos } \\
\text { humanos }\end{array}$ & $\begin{array}{l}\text { APIB aciona } \\
\text { PGR contra a } \\
\text { transferência } \\
\text { para a } \\
\text { Agricultura da } \\
\text { demarcação de } \\
\text { terras indígenas }\end{array}$ & $\begin{array}{l}\text { Sem } \\
\text { contextualizar o } \\
\text { que diz a nota e o } \\
\text { porquê, } \\
\text { publicação é a } \\
\text { nota da APIB na } \\
\text { íntegra }\end{array}$ \\
\hline
\end{tabular}

Tabela 5 - Material produzido pelo Jornalistas Livres

À luz da diferenciação entre notícia e reportagem, vamos analisar um tipo de cada publicação. Compreendemos que as fronteiras entre notícia e reportagem ficam borradas com o uso das tecnologias de informação e comunicação. O tamanho da notícia não precisa necessariamente ser o mesmo do jornal impresso que prevê técnicas como o lead já no 
primeiro parágrafo contendo as informações essenciais da matéria. No jornalismo digital, o lead, além de responder às clássicas questões O quê? Como? Por quê? Onde? Quando? e Quem? precisa envolver e despertar interesse para que o leitor continue a leitura e não seja distraído por links ou outras janelas que se abrem e possibilitam que ele saia da tela.

Há duas razões básicas para a confusão entre a reportagem e notícia. Uma refere-se à polissemia da palavra reportagem que, além de designar certo gênero de texto, é nome da seção das redações que produz indistintamente notícias e reportagens. A segunda resulta da importância peculiar que a estrutura da notícia assumiu na indústria da informação: frequentemente, a reportagem da imprensa diária é escrita com critérios de nomeação, ordenação e seleção similares aos da notícia e apresentada com diagramação idêntica. (LAGE, 2012, p. 8)

O texto "Protestos contra Bolsonaro em Portugal" comunica de maneira direta o registro de atos em três cidades de Portugal já no primeiro dia de posse do presidente Jair Bolsonaro, respondendo no primeiro parágrafo às perguntas do lead.

Um grupo de brasileiros residentes na cidade do Porto fez um protesto, ontem dia 01/01, durante a posse de Bolsonaro diante do consulado brasileiro na cidade do Porto. O protesto organizado pela Frente de Imigrantes Brasileiros Antifascistas do Porto (FIBRA) e o Núcleo Antifascista do Porto (NAP), contou com a participação de dezenas de pessoas. (Jornalistas Livres, 2019)

Na notícia, Bolsonaro e Hitler são colocados lado a lado como sinônimo do nazismo e de uma "ascensão democrática" dos dois candidatos. Essa similaridade de grande apoio popular anuncia na matéria o aceite do resultado eleitoral pelos participantes do ato e oposição de ideias e políticas “[...] que ferem os direitos de diferentes grupos e níveis sociais, serão denunciadas e expostas também por uma oposição internacional."

Mesmo sendo a notícia de um fato com dados e descrição do ocorrido, o texto não se limita somente aos fatores considerados "objetivos", mas também estimula a organização e resistência. O cerceamento de liberdades democráticas faz com que o JL sejam o espaço para esse tipo de pauta que visa organizar setores da sociedade.

Entre as características de comunicação alternativa descritas por Dênis de Moraes (apud COUTINHO, 2008, p. 54) o “[...] envolvimento com causas se manifesta na prevalência de notícias e artigos sobre política, economia, movimentos sociais, direitos de minorias e etnias, ecologia, defesa do consumidor, comunicação, informação, arte e cultura."

Podemos evidenciar essa expressão na análise da reportagem "Contagem aberta: tudo de ruim que Bolsonaro já fez na presidência - Publicação em constante atualização”, na qual o texto demonstra o posicionamento do discurso do arranjo. "Tudo de ruim" em um dia de gestão desnuda a crítica política, o posicionamento e a parcialidade da matéria jornalística. 
Diferentemente da "requisitada imparcialidade" como estratégia discursiva para legitimar uma estratégia de negócio das corporações de mídia, a posição em relação à matéria é nítida. O fato de o adjetivo “ruim' aparecer no título do material também rompe com a artifício invocado pela "necessária neutralidade".

A reportagem é uma espécie de diário em que as decisões políticas do presidente são contadas, por exemplo, a desvalorização do salário mínimo, a facilitação ao acesso e uso de armas, a entrega do texto da reforma da previdência, através desse tema e da seleção de alguns acontecimentos, chama atenção paras as medidas que prejudicarão os trabalhadores. Embora o subtítulo da matéria seja "Publicação em constante atualização", o material deixou de ser atualizado no dia 20 de fevereiro. Uma hipótese para a não atualização é a falta de método e organização do trabalho coletivo a médio prazo. "Falta mão para fazer tudo", afirmou a entrevistada Ana Cláudia da Silva.

As três notas (da Associação Nacional de História - ANPUH Brasil; Associação Nacional dos Magistrados da Justiça do Trabalho - Anamatra; e Conselho Indigenista Missionário - CIMI) demonstram, além do conteúdo expresso, as relações de comunicação em um campo mais amplo de trabalho, da mesma forma os colunistas e colaboradores (dois professores e um pastor evangélico), a seleção do assunto e público leitor.

As editorias política e direitos humanos foram as mais atualizadas no período de análise, tendo no centro do seu discurso o presidente Bolsonaro desde o início de gestão. De maneira reativa, podemos perceber como as pautas estabelecidas por Jair Bolsonaro obtêm espaço na mídia alternativa, mesmo sendo para refratar a pauta ultraconservadora que ele impõe e pauta o conjunto das mídias do país, estabelecendo a sua lógica ao direcionar os assuntos para que a sociedade discuta. Muitas vezes, ao enaltecer um assunto, outros são deixados à sombra, longe da luz dos debates públicos.

Os meios de comunicação jogam papel preponderante na disputa moral, ética e cultural da sociedade. A disputa pela pauta de determinados segmentos sociais a ponto de materializar dada correlação de forças sociais tem como ponto central a comunicação. ${ }^{61}$ Entretanto, ser pautado não é um problema só dos veículos de comunicação alternativa, e sim de um campo social mais amplo que tem perdido as batalhas em defesa de estágio

\footnotetext{
${ }^{61}$ Há diversos estudos sobre o uso de dados obtidos em redes sociais e que têm servido na disputa por recursos naturais, estatais e econômicos. Steve Banon, da Cambridge Analitics, tem sido um dos principais articuladores desse movimento internacional.
} 
civilizacional humano para os setores financeiros. O artigo "Facebook censura tradições milenares" trata esse embate de alguma forma ao denunciar o aplicativo.

\begin{abstract}
\#JornalistasLivres lutamos pela democratização da informação, da comunicação e da vida em sociedade, contra a ditadura de pensamento único instalada dentro das redações convencionais. Agimos por espírito público, jamais por interesses privados. Produzimos reportagem, crônica, análise, crítica, nunca publicidade ou lobby privado. Somos jornalistas-cidadãs e jornalistas-cidadãos, comprometid@s a informar sob a égide da cidadania e do combate às desigualdades. Trazemos notícias d@s frac@se oprimid@s, sabendo que individualmente também somos frac@s e oprimid@s, mas TOD@S JUNT@S SOMOS FORTES.
\end{abstract}

Ademais da cena política nacional, no material analisado há cobertura sobre educação como forma de denúncia do sucateamento da área, cultura com a matéria copiada "É dia de Santo Rei no Ceará", do site Reisado. Outras pautas, como já demonstramos, fazem parte das editorias do Jornalistas Livres.

Entre os quatro arranjos analisados, o Jornalistas Livres é o que mais utiliza a redação virtual como espaço de organização do trabalho. Por sua natureza, criado a partir de experiências de coletivos de comunicação como o Mídia Ninja, que já utilizava a internet como local para estabelecer a rotina produtiva. $\mathrm{O}$ coletivo de jornalistas ao mesmo tempo que apresenta práticas jornalísticas inovadoras também carrega como "herança" o modus operandi da redação das corporações de mídia, visto que muitos jornalistas são oriundos dessas empresas.

A militância acerca da função social do jornalismo faz com que o coletivo seja mais do que um site noticioso, mas um movimento específico que busca democratizar o acesso à informação. Com essa perspectiva, o jornalismo produzido está relacionado à noção de produção de conhecimento sobre o cotidiano e áreas que não fazem parte do plano de cobertura da mídia monopolizada, como movimentos sociais e direitos humanos.

A cobertura dos acontecimentos internacionais sob outro viés diferente do publicado pelas corporações de mídia é a causa da criação do Opera Mundi, arranjo que veremos a seguir.

\title{
Opera Mundi
}

O Opera Mundi tem uma pauta específica de cobertura de acontecimentos internacionais nas áreas de política, economia e cultura e é um dos poucos veículos que se 
coloca como alternativo e que sobrevive há mais de dez anos. Fundado em dezembro 2008, o site se coloca como "[...] assumidamente crítico e com posições à esquerda no espectro político".

No lugar do anúncio da imparcialidade e neutralidade tão presentes no jornalismo, a política editorial do arranjo é anunciada com clareza e sem tergiversações, ao mesmo tempo em que identifica o seu público leitor.

Na coletânea de reportagens do site, o jornalista Haroldo Ceravolo, coordenador geral, pontua que o arranjo tem heranças jornalísticas de veículos como o Pasquim, Movimento, Carta Maior entre outros em referência à mídia alternativa e como um veículo informativo que respeita “[...] os diversos lados da notícia, fuga da militância enviesada e da crítica fácil, abertura a posições distintas e recusa ao sectarismo."

Contudo, através da citação acima podemos inferir a junção de jornalismo com a atividade de agitação e propaganda no momento do segundo governo de um partido que evocava o posicionamento de esquerda. A expressão "militância enviesada e recusa ao sectarismo" pressupõe uma política editorial direcionada para militantes da esquerda que nas circunstâncias do nascimento do veículo atuavam no poder central do país.

A criação do Opera Mundi (OM) dialogava com o cenário político da gestão do expresidente Luiz Inácio Lula da Silva, que trazia novas experiências na área de política internacional, nas relações Sul-Sul, na formação de blocos comerciais como os Brics (Brasil, Rússia, Índia, China e África do Sul) e o reposicionamento do Mercosul em decorrência da mudança nos governos da América Latina. Esses fatos fizeram crescer o interesse do público nacional para as notícias mundiais. "Essa mudança no posicionamento do país e do brasileiro em relação ao mundo também foi uma das transformações que favoreceram o projeto jornalístico.” (CERAVOLO, 2014, p. 13)

O fundador do site, o jornalista Breno Altman, desde jovem atuava em movimentos de solidariedade internacional através do Partido Comunista Brasileiro e, junto com outro jornalista, Roberto Cosso, fundou o site através de duas empresas chamadas Entrelinhas e Última Instância. Esta última saiu do arranjo em 2015.

As mudanças no cenário político internacional e as oportunidades derivadas da redução de custos para a produção de material jornalístico foram dois fatores essenciais para criação do Opera Mundi. 
O desenvolvimento da internet permitiu que os gastos com infraestrutura fossem significativamente reduzidos, e mais importante que isso, planejáveis. O volume de recursos e pessoal necessário para a criação e manutenção de projetos jornalísticos foi reduzido, enquanto o público tendia a aumentar rapidamente. (CERAVOLO; TERRA, 2014, p.13)

Entretanto, isso não significa que nas matérias não haja preocupação com o tratamento da informação. Durante a observação de campo feita, pudemos verificar alta especialização sobre a situação de países que não costumam ser pautas de veículos da mídia monopolizada. A forma de tratar o conflito na Síria, as tendências intrapartidos, os fatores sociais e econômicos que motivam convulsões no país são debatidos na reunião de pauta do arranjo.

Nesse contexto, os profissionais buscam ser agentes no processo de democratização da informação ao ter no centro de sua produção assuntos que não fazem parte da pauta da mídia tradicional. Além disso, estar apoiado em uma rede de colaboradores, como foi no início, fazia com que o site tivesse a aparência de coletivo de correspondentes em diferentes lugares do mundo para ampliar o acesso às informações internacionais, embora fosse criado por uma associação privada, acarretando em não precisar ter uma política transparente de arrecadação de recursos ou mesmo quanto à construção de sua pauta.

Distintamente do momento de criação do arranjo, no período analisado por essa pesquisa havia poucos colaboradores e correspondentes internacionais e não conseguimos entrevistá-los para saber se o fato de ser uma empresa, quando a fundação do site, era de conhecimento desses colaboradores e se implicava nas relações de colaboração da rede à qual se apoiavam os proprietários do OM.

Ao contrário de veículos em que a disputa pelo furo os distancia de uma prática jornalística coletiva ou minimamente combinada, o Opera Mundi participa de coberturas, troca de conteúdo e informação com outros sites da área. Aliás, essa é uma característica de muitos arranjos da comunicação alternativa que buscam atuar entorno da relevância pública da atividade jornalística. Dois exemplos dessa postura são a participação do arranjo na articulação da Conta $D^{\prime}$ Água $^{62}$ e, alguns meses depois, na fundação do Jornalistas Livres.

Essa lógica de participação de outros coletivos e colaboradores que estão fora do quadro pessoal acontece em menor grau no próprio arranjo. De modo diferente dos tempos dos governos de Lula, a participação de leitores, colaboradores e mesmo quanto aos

\footnotetext{
${ }^{62}$ Como já citada, a Conta D’Água foi uma articulação unitária com arranjos da mídia alternativa para cobertura da crise hídrica em São Paulo.
} 
trabalhadores é diversa e mais enxuta que a descrição feita no livro de Ceravolo e Terra (2014).

Dentro do processo de produção dos materiais jornalísticos, durante a trajetória da nossa pesquisa, atuavam diretamente no arranjo três estagiários, três jornalistas, uma pessoa responsável pelo "comercial" e alguns colaboradores ocasionais com a escrita de notas e artigos.

A forma jurídica do Opera Mundi é uma associação privada e segue essa lógica nas relações de trabalho e vínculo empregatício. A organização é centralizada quanto ao fluxo de trabalho, sendo pouco permeável para participação mais ampla da sociedade, como era a proposta em sua criação.

No caso do Opera Mundi, há um proprietário que não é aparente na organização do trabalho, mas sim na produção jornalística. Durante as visitas na redação física e na virtual, onde ficamos por oito meses, não encontramos o proprietário nenhuma vez.

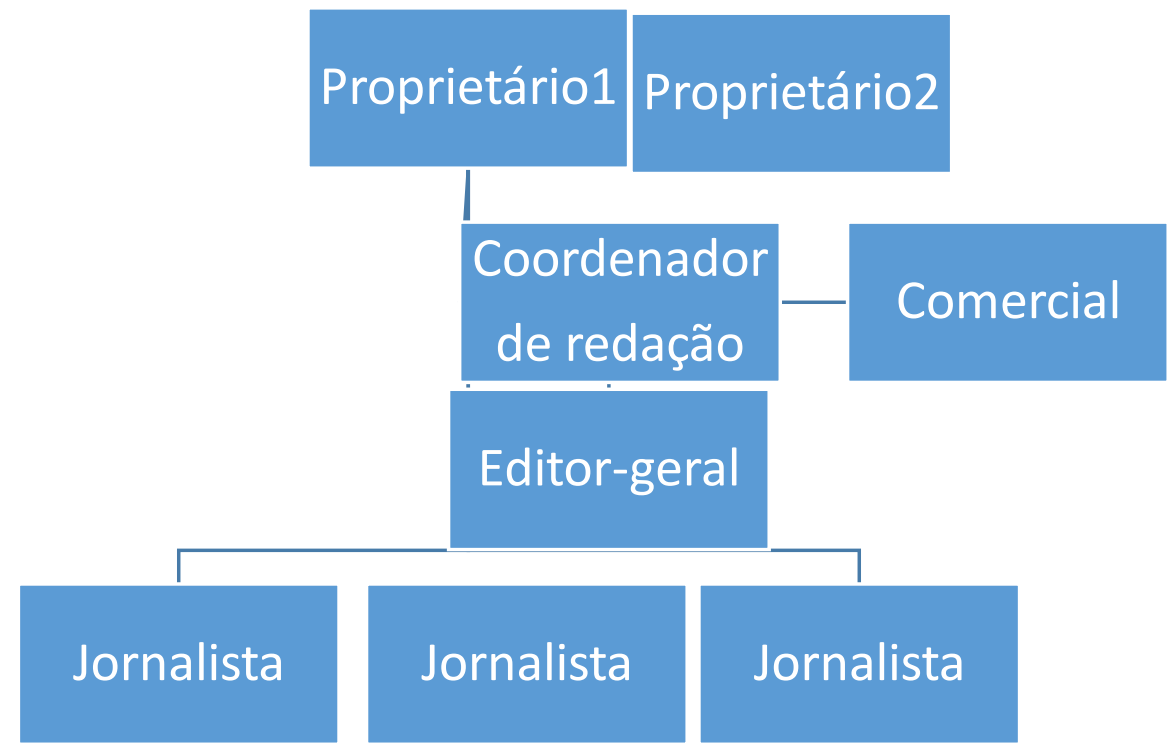

Figura 23 - Organograma do Opera Mundi - Fonte: Imagem da autora

A ilustração da hierarquia mostra a organização de trabalho parecida com a da redação das grandes empresas de jornalismo. Uma estrutura altamente hierarquizada onde abaixo do proprietário vem a figura do coordenador de redação responsável pela condução do arranjo. Como trabalha à distância e coincide com outro trabalho, a presença do diretor é mais frequente na redação virtual e durante a reunião de pauta. Representa o ponto de vista mais 
geral, faz mais observações sobre os caminhos da pauta e sobre a posição do veículo diante de determinados temas, além de sugerir as pautas, editar os textos, apontar correções, enfoques e destinar atribuições para o restante da equipe, incluindo a área comercial.

A representante comercial avalia os dados das redes sociais (Facebook, Twitter, Youtube), os números de acesso do site e, em cima dessas informações, opera a venda de publicidade e o investimento com impulsionamento de publicações para alcançar mais seguidores e relevância de acordo com as métricas dessas plataformas. $\mathrm{O}$ acompanhamento de assinaturas também é feito por profissional específico.

O editor geral responde ao coordenador de redação e acompanha a construção das pautas no dia a dia. É quem decide a matéria de destaque, distribui e acompanha a realização das pautas, edita os textos. Nas próprias palavras de Paulo Correia:

[...] sou responsável por pautar os meninos, ficar de olho no noticiário, olhar o que o site vai dar ou não. Essa decisão acaba sendo minha no final. (...) Tem uma salinha dele e o cargo de diretor de redação nem é para fazer isso. Ele pede as coisas, orienta de forma mais geral e editorial do que de pauta. Então, eu cuido de pauta, texto, questões administrativas como decisão de folgas, plantão e nesse momento eu tenho ajudado na manutenção porque a gente não tem um secretário. (Paulo Correia, 2018)

Os estagiários de jornalismo fazem diversas atividades: pesquisa de pauta, elaboram matérias para o site, alimentam as redes sociais, produzem produtos em audiovisual, montam o boletim de notícias enviado por e-mail para os inscritos no site.

Durante as reuniões de pautas, a discussão é feita para organizar a produção. Já na redação virtual a principal função é o acompanhamento e controle da produção.

Vejamos a seguir a organização da produção da matéria jornalística:

\begin{tabular}{|l|l|}
\hline Rotina de produção & Descrição \\
\hline Pauta & $\begin{array}{l}\text { Reuniões fechadas, geralmente uma vez } \\
\text { por semana, na qual a equipe debate os } \\
\text { assuntos relacionados à política editorial. } \\
\text { Colaboradores enviam pautas, } \\
\text { informações ou matérias produzidas pela } \\
\text { caixa de mensagem das redes sociais }\end{array}$ \\
\hline Apuração & $\begin{array}{l}\text { Checagem, ligação para fontes, pesquisa } \\
\text { sobre o tema em sites e jornais correlatos }\end{array}$ \\
\hline Edição & $\begin{array}{l}\text { Editor geral faz a edição da matéria. } \\
\text { Revisão do material enviado por }\end{array}$ \\
\hline
\end{tabular}


Tabela 6 - Caminho da produção jornalística no Opera Mundi

Mais uma vez, podemos perceber aspectos semelhantes com os das grandes redações quanto à produção. A diferença é que os jornalistas apontam ter mais liberdade para propor os assuntos. Como há uma sede física, as conversas sobre o jornalismo são feitas no ambiente de trabalho, mas até 2017 também era frequente ser feito na redação virtual.

\section{Redação virtual e física}

Como vimos, o Opera Mundi faz uso da redação virtual para acompanhar a produção, visto que tanto o proprietário quanto o coordenador da redação acompanham o trabalho à distância. Já a redação física é a principal organizadora das práticas jornalísticas.

Em determinado momento de reposicionamento da associação, a solução apontada para diminuir os custos de produção foi sair da sede física e todos trabalharem à distância, em regime home office. Mas os próprios jornalistas convenceram o dono do site que o melhor seria continuar com um espaço físico porque:

[...] elas se sentiram muito incomodadas de trabalhar em casa. De não ter a separação de horário de trabalho e tal, mas também porque algumas pessoas moram em apartamentos muito pequenos, então para elas seria um custo pessoal muito alto, sabe? Esse foi o principal argumento que pegou; a redação como um todo era favorável a ter um espaço comum porque ela entende que o jornalismo funciona melhor com esse espaço do que com relacionamentos virtuais, digamos assim. (Entrevistado do CPCT, 2018)

Os jornalistas perceberam que ao mudar a forma de organização do trabalho, alteraria também o valor de seu trabalho, sendo que eles seriam os responsáveis pela estruturação do site, saindo diretamente de seu bolso os valores do maquinário, energia elétrica e por não ter clareza sobre qual seria o tempo de trabalho e não trabalho dispendido. $\mathrm{O}$ cronotopo (BAKHTIN, 2014) da redação física demanda outros investimentos pessoais em termos de separação do trabalho oficial e do trabalho fora do lugar de trabalho.

Essa discussão foi feita de forma aberta, desencadeando uma mudança quanto ao uso de aplicativos de conversa. Antes da mudança, o arranjo tinha um grupo no WhatsApp para facilitar a gestão do proprietário. O espaço não tinha regras, as pessoas enviavam mensagens a 
qualquer horário e a falta de padrão fez com que cessasse o diálogo no grupo enquanto espaço social que organizava o trabalho e se transferisse a redação para o Gtalk ${ }^{63}$.

Outro fator que unificou a redação foi a própria qualidade do jornalismo. De acordo com Paulo Correia, na redação virtual a conversa é muito "truncada" enquanto na física a comunicação acontece de maneira mais fluída.

Você consegue ver o que a pessoa está fazendo, se está ocupada ou não está, ao
invés de ficar perguntando no chat "você está aí"? O que você está fazendo? Na sede
a pessoa está, você pode falar com ela, estar todo mundo junto, eu não diria que
agiliza a produção, mas deixa a produção mais fácil porque, por exemplo, se o
Jornalista X tem uma dúvida, ele vira a cadeira e pergunta, não precisa pegar,
escrever, apagar, ou talvez eu não esteja no chat, entendeu? Estar junto acelera o
processo e fora que é legal ter uma redação, as pessoas podem conversar, tem um
nível de descontração que servem para tirar a pressão. Sendo que num chat você vai
no máximo mandar um GIF. (Paulo Correia, 2018)

Do ponto de vista do trabalho, o espaço comum incide na qualidade do jornalismo. Ao comparar os números da audiência com e sem espaço físico, segundo Correia, a diferença no alcance foi grande. A produção à distância é mais lenta, exige estar sempre conectado em plataformas que disputam atenção, conversas que fazem vibrar o aparelho celular ou qualquer tipo de aplicativo.

Ao olhar para as condições discursivas com apoio de Maingueneau (2001), que estabeleceu como método operacional a distinção entre suporte material de produção, situação de difusão e situação de recepção e considerando as características e materialidade da mídia, o público e o ambiente que compõem o momento de comunicação, podemos inferir que há diferenças significativas na comunicação na redação virtual e na física.

No ambiente da redação, observamos a modulação da voz, a troca de impressão sobre uma notícia, a discussão sobre jornalismo que surge no meio do expediente ou mesmo a torcida para um time que disputava a Copa do Mundo enquanto a televisão transmitia o campeonato no meio da redação. Em um país no qual a oralidade tem longa existência como fonte histórica há, conforme o autor, enunciados estáveis - que são preservados no tempo - e os instáveis, que se perdem com mais facilidade.

Em nosso caso concreto de análise, as relações são mediadas através de um aplicativo privado, manuscrito na qual tanto a difusão quanto a recepção são à distância.

Em um grupo com o chefe, o profissional pensa muitas vezes antes de escrever, ele pode voltar a atrás, apagar, corrigir uma expressão antes de enviar - e agora pode até apagar a mensagem antes que o destinatário veja.

\footnotetext{
${ }^{63}$ Aplicativo de conversa da Google.
} 
As situações do ato enunciativo intervêm na produção da comunicação e, consequentemente, o processo de troca e cooperação é essencial para a produção jornalística.

Após algumas discussões entre a direção e os profissionais esse foi o principal argumento para manter o espaço físico considerado investimento para o arranjo.

É interessante notar a percepção acerca do valor do trabalho pelos profissionais que resistiram às mudanças que os afetaria do ponto de vista da saúde e corrosão do salário. Essa percepção e a decisão de manter o espaço físico só são possíveis de tornarem-se consciente de suas condições de produção porque houve um processo de diálogo entre os jornalistas e a decisão de fazer o debate com a direção, iniciativas impossíveis de acontecer quando o trabalho é em regime home office.

Durante a nossa observação de campo, ficamos na redação virtual por oito meses do Opera Mundi e recebemos o histórico de conversas anteriores do grupo que funcionava através do WhatsApp.

Na redação do Gtalk (após a negociação e saída do WhatsApp), a grande maioria das mensagens era sobre a produção publicada. A mensagem "Subiu. Está no ar." é transmitida junta com o link da matéria. Após a publicação, o diretor usa o grupo para apontar correções na matéria. Para o entrevistado Leonardo Santos é um espaço para ser publicado o que é feito na redação física:

\footnotetext{
Ali a gente coloca as matérias que estão entrando, por exemplo, a gente coloca a matéria no ar. Fica só entre a gente para gente saber o registro do que foi publicado, o horário, a distância entre uma matéria e outra. E a gente também usa para comunicação maior também. Às vezes o Olímpio Cruz manda um link, ou OM2 e fala vamos atrás disso, uma comunicação mais focada. Se eu estou de longe, de casa ou no plantão e eu quero discutir algo que vai render muitas mensagens com o Rafa, eu vou discutir no privado com ele. Ali são mensagens mais relevantes, coisas para gente ir atrás, o que foi publicado. É um chat da redação, sobre o que está sendo feito na redação. (Leonardo Santos, 2018)
}

Já no grupo de WhatsApp, as discussões contavam com a participação do proprietário, do diretor e dos jornalistas que atuavam na redação. O foco do grupo é a seleção de assunto, materiais, elaboração do material jornalístico, contato com as fontes, edição de títulos, legendas e outros aspectos da constituição do material. Por exemplo: "Sobre o Milosevic, essa informação não é verdadeira. O que acontece é que ele não foi citado em um caso específico da Corte de Haia (ao qual ele não estava sendo julgado). Foi uma notícia falsa divulgada pela RT e reproduzida por outros veículos.” (Observação Redação Virtual, 17/8/2016)

Diferentemente da redação virtual do Jornalistas Livres, a discussão no espaço é mais fechada e a voz predominante é do dono do site com a proposição e indagação quanto às 
matérias produzidas. É o local onde chega a pauta selecionada pelos jornalistas como essa: "URGENTE! MORREU FIDEL! TEMOS QUE IMEDIATAMENTE COLOCAR NO AR COBERTURA ESPECIAL!” As palavras maiúsculas reforçam a urgência da ação imediata.

Do mesmo modo, a gestão do tempo era tema na redação virtual: "Então não sei se dá tempo... tô terminando a nota que vc pediu das entidades para colocar na manchete, aí ainda preciso trocar a home e enviar o boletim... e meu plantão acaba às 17h." (Observação da redação virtual, 30/08/2017)

Assim também como a seleção de conteúdo de sites acompanhada dos devidos links como essa: "Vamos fazer, urgente, uma matéria sobre essa matéria: https://www.washingtonpost.com/politics/congress/3-men-in-line-for-brazilian-presidency-accused-ofcorruption/2016/08/30/43939382-6eb2-11e6-993f-73c693a89820_story.html\#”. （Observação da redação virtual, 20/7/2016)

A possibilidade de inserir o hiperlink agiliza a busca da matéria. Em uma conversa presencial não é possível falar com precisão o link, no máximo descrever o assunto e o site para que a matéria seja copiada.

Durante a observação da redação virtual do Opera Mundi, observamos que há pouca discussão e o espaço serve mais para prestação de contas dos jornalistas para os seus chefes imediatos que ficam fora da redação física. Como utilizam ambos os espaços, é na redação física que é organizada toda a produção.

Nesse caso, podemos observar que a redação virtual é utilizada como método de sistematização das matérias. O jornalista inicia o seu trabalho com a checagem do que foi produzido para não pegar a mesma pauta. Porém, também serve para diálogos curtos sobre a pauta e isso é feito, por exemplo, por Paulo Correia, enquanto se desloca de casa para o local de trabalho.

A linha editorial, a seleção dos assuntos que entram na pauta, a orientação para o uso de diferentes plataformas como esta retirada dos diálogos da redação virtual: "Pessoal, como ontem, nossa principal frente eh o Twitter hoje até o fim do impeachment, ok?"

$\mathrm{Na}$ redação física, há mais entrosamento entre os jornalistas que atuam no mesmo espaço e a relação com os superiores é de hierarquia determinada, já que no cotidiano essas figuras são ausentes. 
Não há debates abertos em que o profissional e os dirigentes estejam no mesmo patamar. O caso mais próximo foi sobre a discussão levantada através da escolha de uma matéria.

\begin{abstract}
Proprietário: faça uma reunião com a equipe, rápida, e discuta a questão, para que todos entendam e coloquem dúvidas concretas para diminuir o número de casos assim.
\end{abstract}

Editor: no momento a equipe soy yo, mas vou mandar e-mail pra geral agora mesmo

Proprietário: Não, e -mail não. Conversa quando a equipe estiver toda, ou em boa parte, aí. Se faltar alguém, converse depois, mas é assunto para conversa, não por mensagem ou e-mail. É assunto para discutir, não para orientar para pessoas se engajarem no assunto.

Editor: Sim, reitero amanhã, quando estivermos todos aqui

Proprietário: Reitera, não. Abra a discussão. Ouça as dúvidas, coloque as suas. Cheguem a um acordo que envolva todos. Porque daí não tem mais erro. Não importa quem fez, mas tem de ser um acordo geral. Daí você me comunica o que concluíram. (Observação da redação virtual, 2017)

Como a mesma equipe da redação atuava na revista Samuel, além do Opera Mundi, o engajamento almejado pela direção era sobre a produção da pauta para os dois veículos de comunicação, bem como na distinção da pauta entre os projetos.

Essa foi a época em que havia mais profissionais contratos já que a revista contava com o patrocínio da empresa área Gol.

\title{
O jornalismo produzido no Opera Mundi
}

$\mathrm{Na}$ atividade prática de jornalismo há algumas tensões presentes na redação do OM. Durante a discussão de pauta sobre um jogador de vôlei transexual, a redação se sentiu incomodada a ponto de negar-se a fazer a pauta. Segundo Olímpio Cruz (2018), “[...] há um conflito geracional. A geração mais nova não quer tratar de alguns temas. Os conflitos fazem parte da vida. Não existe tema que seja tabu, mas o que vale é a sua cobertura ética do assunto. Sou mais jornalista 'da antiga'."

Esses conflitos emergem durante a reunião de pauta e nas conversas cotidianas, porém, é no espaço de construção da pauta que as diferenças ficam mais cristalizadas.

Como vimos na apresentação, o arranjo "[...] é especializado na cobertura do noticiário internacional de política, economia e cultura, partindo de uma perspectiva latino-americana."

A segmentação proporcionada pela internet como plataforma de distribuição de notícias impulsionou o chamado jornalismo de nichos, em que há a oferta de um recorte 
editorial de maneira especializada, com base em pesquisa, reflexão e conhecimento sobre o assunto.

Mais do que uma estratégia jornalística, a segmentação da pauta é uma tática de sobrevivência de profissionais que são demitidos com o enxugamento das redações e buscam na internet uma forma de continuar trabalhando no jornalismo. Longe de hardnews, novos arranjos se organizam em torno de temas como feminismo, com foco na igualdade racial, veículos que tratam a criminalização do racismo e a promoção da igualdade racial, de segurança pública e direitos humanos, política nacional, periferia, tecnologia e outras diversas segmentações da atividade jornalística.

Essa realidade dialoga com a organização do trabalho através de projetos que envolvem diferentes capacidades dos jornalistas. Com o processo de reestruturação do processo produtivo capitalista, o projeto é uma situação de trabalho que envolve uma especificidade podendo ser duradouro - se tiver êxito - ou prazo curto para encerrar. É a organização sobre demanda de um tema específico em que a equipe pode ser moldada para atingir determinados objetivos.

Entre os assuntos que orientam a pauta do OM, o conflito duradouro na Venezuela é um dos destaques, assim como a situação política na América Latina em geral, por exemplo, o governo da Argentina, o México por suas semelhanças com o Brasil, o governo de Donald Trump e as consequências de suas ações em nível mundial e as relações internacionais do presidente Jair Bolsonaro.

(...) Hoje os Estados Unidos porque aquele cara é louco e acho que o Bolsonaro vai ser igual. Nessas últimas semanas para cá o Bolsonaro tem entrado muito na pauta, como exceção do começo de lamber as feridas da eleição dele, ele tem entrado hoje com o foco internacional com essa 'pataquada' do Egito e Israel. Europa a gente acompanha com atenção a Alemanha, isso tem algo meu, porque morei lá e o fato de falar alemão ajuda bastante porque dá coisas e que ninguém mais dá e que são importantes. Oriente Médio também é muito caro para gente. (Paulo Correia, 2018)

As fontes de informações são as mais variadas dentre política internacional. Leonardo Santos, jornalista do arranjo entrevistado nessa pesquisa, quando chega ao trabalho busca por Telesur, Cuba Debate, agências estatais, Página 12, Telan, Clarín, Times, The Guardian, Washington Post, A Folha de S. Paulo, o Estadão, o El País. Entre os veículos similares e, de certa forma parâmetros, conforme lista Olímpio Cruz, estão o Outras Palavras, Revista Fórum, Carta Maior, Agência Pública e Caros Amigos. 
O arranjo mantém periodicidade diária. A manchete do site é trocada duas vezes ao dia - de manhã e ao final do dia - e a produção é maior do que os outros três sites. Durante o período de coleta (de 1 a 7 de janeiro de 2019) foram postadas 23 matérias. Vejamos, a seguir, a lista:

\begin{tabular}{|c|c|c|c|}
\hline Data & Editoria & Título & Descrição \\
\hline $1 / 1 / 2019$ & $\begin{array}{l}\text { Política e } \\
\text { economia }\end{array}$ & $\begin{array}{l}\text { Presidentes, } \\
\text { premiês e } \\
\text { chanceleres } \\
\text { participam da posse } \\
\text { de Bolsonaro; veja } \\
\text { quais são }\end{array}$ & $\begin{array}{l}\text { Matéria da Agência } \\
\text { Brasil }\end{array}$ \\
\hline $1 / 1 / 2019$ & Cultura & $\begin{array}{l}\text { EUA e Israel } \\
\text { deixam oficialmente } \\
\text { a Unesco }\end{array}$ & $\begin{array}{l}\text { Matéria da Deutsche } \\
\text { Welle }\end{array}$ \\
\hline $1 / 1 / 2019$ & Memória & $\begin{array}{l}\text { Revolução Cubana - } \\
60 \text { anos de } \\
\text { resistência }\end{array}$ & $\begin{array}{l}\text { Matéria feita pelo jornal } \\
\text { Brasil de Fato }\end{array}$ \\
\hline $1 / 1 / 2019$ & $\begin{array}{l}\text { Política e } \\
\text { economia }\end{array}$ & $\begin{array}{l}\text { 'Não vamos baixar a } \\
\text { cabeça, nem deixar } \\
\text { que tirem nossa } \\
\text { alegria de viver' }\end{array}$ & $\begin{array}{l}\text { Matéria da Rede Brasil } \\
\text { Atual }\end{array}$ \\
\hline $1 / 1 / 2019$ & Memória & $\begin{array}{l}\text { Revolução Cubana } \\
\text { completa } 60 \text { anos; } \\
\text { saiba como foram } \\
\text { os momentos que a } \\
\text { antecederam }\end{array}$ & $\begin{array}{l}\text { Matéria feita pelo } \\
\text { Sputnik }\end{array}$ \\
\hline 2/1/2019 & $\begin{array}{l}\text { Política e } \\
\text { economia }\end{array}$ & $\begin{array}{l}\text { Caracas condena } \\
\text { 'atitude } \\
\text { intervencionista' de } \\
\text { Brasil e EUA após } \\
\text { reunião de } \\
\text { Bolsonaro e } \\
\text { Pompeo }\end{array}$ & Matéria própria \\
\hline $3 / 1 / 2019$ & Diplomacia & $\begin{array}{l}\text { Com Raul Seixas, } \\
\text { grego arcaico e } \\
\text { Olavo de Carvalho, } \\
\text { novo chanceler } \\
\text { toma posse e critica } \\
\text { 'globalismo' na }\end{array}$ & Matéria própria \\
\hline
\end{tabular}




\begin{tabular}{|c|c|c|c|}
\hline & & política externa & \\
\hline 3/1/2019 & Diplomacia & $\begin{array}{l}\text { Líderes e } \\
\text { organizações } \\
\text { mundiais criticam } \\
\text { declarações de } \\
\text { Grupo de Lima e } \\
\text { manifestam apoio à } \\
\text { Venezuela }\end{array}$ & Matéria própria \\
\hline $3 / 1 / 2019$ & $\begin{array}{l}\text { Política e } \\
\text { economia }\end{array}$ & $\begin{array}{l}\text { Presidente da China } \\
\text { envia carta a } \\
\text { Bolsonaro }\end{array}$ & $\begin{array}{l}\text { Matéria feita pelo Jornal } \\
\text { China Daily, publicada } \\
\text { pela agência ANSA }\end{array}$ \\
\hline 4/1/2019 & $\begin{array}{l}\text { Política e } \\
\text { economia }\end{array}$ & $\begin{array}{l}\text { EUA - Agora sob } \\
\text { maioria democrata, } \\
\text { Câmara desafia } \\
\text { Trump e aprova } \\
\text { Orçamento sem } \\
\text { dinheiro para muro }\end{array}$ & Matéria própria \\
\hline $4 / 1 / 2019$ & $\begin{array}{l}\text { Política e } \\
\text { economia }\end{array}$ & $\begin{array}{l}\text { Espanha se tornou } \\
\text { principal porta de } \\
\text { entrada na Europa } \\
\text { de migrantes que } \\
\text { vêm pelo } \\
\text { Mediterrâneo, diz } \\
\text { OIM (2) }\end{array}$ & Matéria feita pela RFI \\
\hline $5 / 1 / 2019$ & $\begin{array}{l}\text { Política e } \\
\text { economia }\end{array}$ & $\begin{array}{l}\text { 'Coletes Amarelos' } \\
\text { realizam primeiro } \\
\text { protesto do ano na } \\
\text { França }\end{array}$ & Matéria própria \\
\hline $6 / 1 / 2019$ & $\begin{array}{l}\text { Política e } \\
\text { economia }\end{array}$ & $\begin{array}{l}\text { Cuba publica } \\
\text { integra do texto da } \\
\text { nova Constituição }\end{array}$ & Matéria própria \\
\hline 7/1/2019 & $\begin{array}{l}\text { Política e } \\
\text { economia }\end{array}$ & $\begin{array}{l}\text { EUA e China se } \\
\text { reúnem em Pequim } \\
\text { para discutir guerra } \\
\text { comercial }\end{array}$ & Matéria própria \\
\hline 7/1/2019 & $\begin{array}{l}\text { Política e } \\
\text { economia }\end{array}$ & $\begin{array}{l}\text { Militares tentam dar } \\
\text { golpe de Estado no } \\
\text { Gabão }\end{array}$ & $\begin{array}{l}\text { Matéria da Agência } \\
\text { Deutsche Welle }\end{array}$ \\
\hline $8 / 1 / 2019$ & Diplomacia & $\begin{array}{l}\text { Venezuela acusa } \\
\text { Grupo de Lima de } \\
\text { incentivar golpe de }\end{array}$ & $\begin{array}{l}\text { Matéria própria a partir } \\
\text { de notícia publicada pela }\end{array}$ \\
\hline
\end{tabular}




\begin{tabular}{|l|l|l|l|}
\hline & & Estado contra o país & Agência Brasil \\
\hline
\end{tabular}

Tabela 7 - Material produzido no período de coleta

Como podemos conferir, a editoria de política e economia agrega mais conteúdo; do total, dez matérias foram agrupadas na seção. Outro fator de questionamento é a ausência de identificação do jornalista do arranjo. Nas matérias próprias não há qualquer identificação, apenas "pela redação" no início da matéria que também é citada nas matérias extraídas das agências. Esse fator é comum em coletivos horizontais, como acontece no Mídia Ninja, cujo crédito é apenas o nome do arranjo.

A crônica, artigo e a nota internacional são feitas em regime de colaboração e assinadas pelos autores que, muitas vezes, recebem a projeção de seu nome e ideias como troca pela elaboração do material.

A redação trabalha com a leitura, reescrita, escrita e pesquisa de assuntos em uma combinação entre produção própria, assinatura de conteúdo das agências internacionais e a participação de colaboradores.

As matérias seguem o padrão técnico de uso de lead, a utilização de mais de uma fonte. Porém, é imprescindível a apuração e a capacidade de tradução, visto que as fontes são de fora do país. Outro fator é que o trabalho é feito majoritariamente dentro da redação, devido ao próprio assunto e ao custo para viagens internacionais. Por isso, a importância da rede de correspondentes internacionais.

Podemos averiguar também a prática de utilizar como fontes as agências internacionais (RFI, Deutsche Welle, ANSA) e sites informativos considerados do espectro da comunicação alternativa, como o jornal Brasil de Fato e Rede Brasil Atual. 


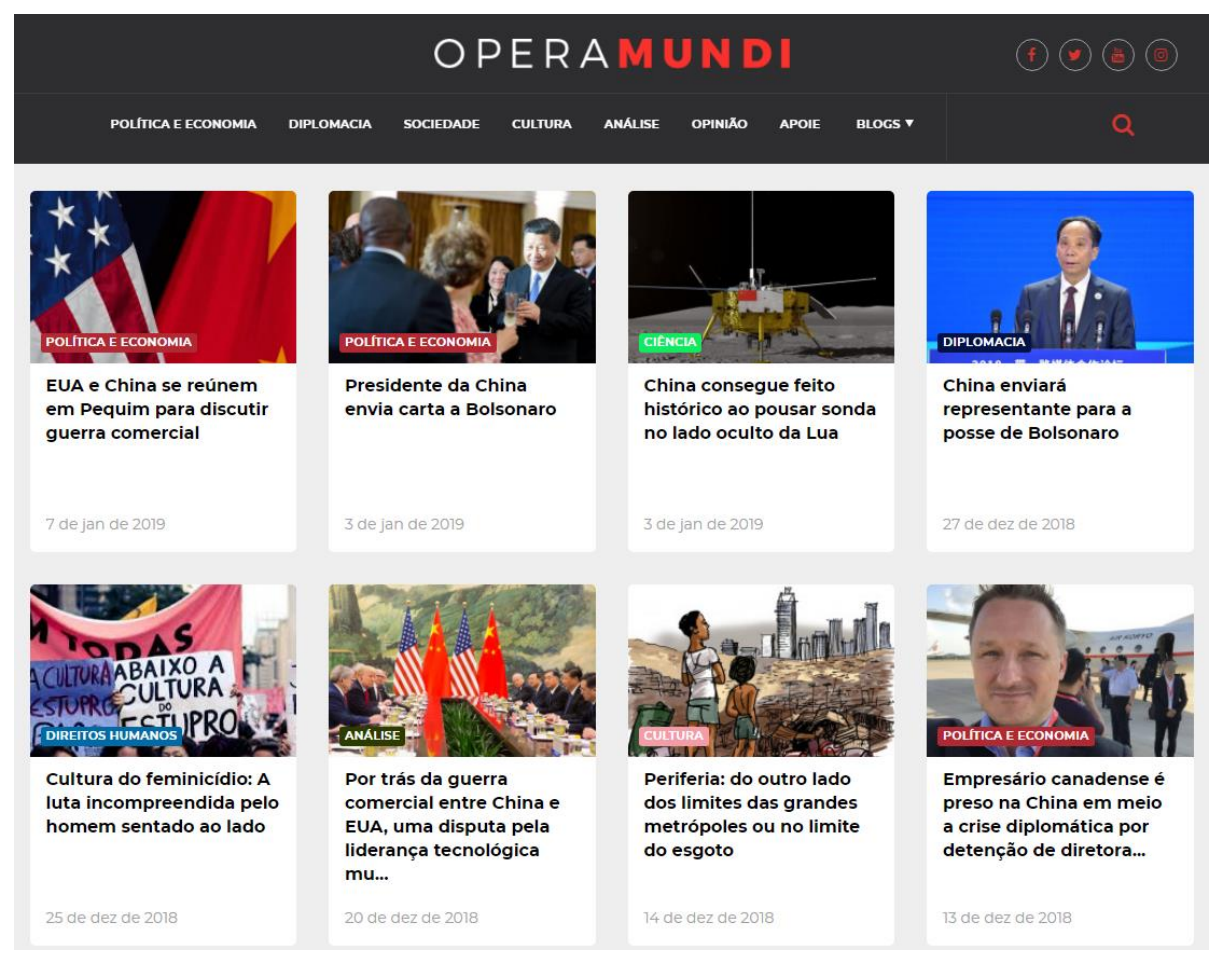

Figura 24 - Site do Opera Mundi

O site é estruturado sob as editorias que ficam aparentes em todo conteúdo junto com a ordem cronológica. Não é raro ver a publicação de conteúdo sem a data. A internet diminuiu o tempo do furo, ou seja, o tempo para realização de uma matéria exclusiva é imediato e tornou a validade do tempo da matéria de forma mais elástica. O seu tempo de circulação vai desde o imediatismo do furo até a validade do próprio conteúdo em si, deslocando a percepção de periodicidade da análise do período ou jornada da qual deriva o nome da profissão - jornalista.

Durante a pesquisa do CPCT, deparamos com o site de futebol de várzea Punteiro Izquierdo, o qual dizia: “[...] a nossa periodicidade é a seguinte: quando tivermos algo importante para falar viemos aqui para te contar.” Esse exemplo demonstra como a noção de periodicidade é concebida em arranjos que não têm o compromisso de contar fatos e acontecimentos novos ao seu leitor dentro de período estabelecido, a não ser "os mais importantes", conforme julgamento do jornalista do site.

Nesse caso concreto, no Opera Mundi a periodicidade ajuda a organizar o trabalho. Trocar a manchete do veículo, por exemplo, é a primeira atribuição do dia que fica a cargo do editor. Há uma regularidade e frequência para a publicação da matéria jornalística. 
Aqui há um tensionamento em torno da diferença entre periodicidade e regime de atualização. Regime de atualização pressupõe um regulamento regente da atualização de um site que não é conduzido pelo tempo de publicação da matéria.

A nossa percepção dessa tensão é a relação entre a força de trabalho dispendida para a produção e o compromisso com a periodicidade ser um dos pilares do jornalismo produzido. Quando o trabalho é voluntário não há horário fixo para organizar a produção, porém quando há trabalho contratado por um número de horas, a execução da produção jornalística se dá em espaço e tempo determinado orientado pelo gênero feito na redação.

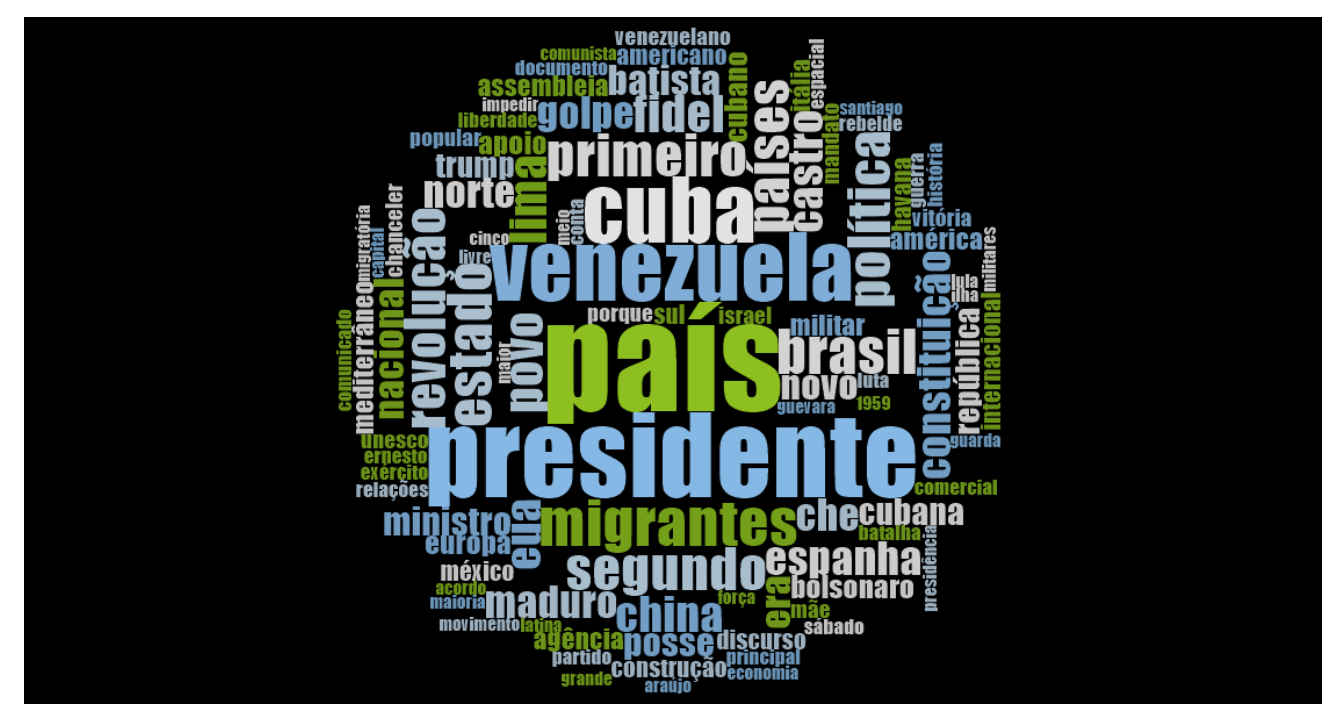

Figura 25 - Nuvem de palavras mais usada - Fonte: NVivo

Com visualização das palavras mais utilizadas na amostra, podemos atestar que, assim como é afirmado na apresentação do site, o enfoque é a política internacional sob viés de esquerda. "Che", "Venezuela", "Maduro", "Cuba", "povo", "revolução", "China", "luta", "liberdade", "rebelde" entre outras fazem parte do léxico utilizado pelo Opera Mundi.

As palavras "governos", "presidente" e "país" têm uso específico dentro do conteúdo para designar o país e o presidente em questão, sendo de Cuba, Venezuela, China ou Brasil e demonstram que, ao narrar o fato dos países, a articulação com dimensão política da matéria passa pelo posicionamento dos governantes.

No geral, percebemos que o fator nucleador da política editorial ser um site progressista de política, economia e cultura internacional voltado à militância está presente nas matérias e na expectativa dos leitores do arranjo, que demarca a sua posição na sociedade como estratégia de estabelecer um nicho de oportunidade para cativar o público leitor. 
A sustentação material se dá através do leitor. As contribuições mensais são responsáveis pela manutenção do arranjo por mais de dez anos. Entretanto, a percepção de Thiago de Assis (2018) é de "uma possível crise" a todo momento, devido à "fragilidade" dessa fonte de recursos.

O site tem como fonte a venda de anúncios, a elaboração de materiais didáticos para escolas particulares, e apoiadores solidários que contribuem mensalmente de $\mathrm{R} \$ 13$ até $\mathrm{R} \$ 52$. Apoiadores podem contribuir com único auxílio entre $\mathrm{R} \$ 80$ até $\mathrm{R} \$ 2$ mil. Atualmente 200 pessoas fazem parte do sistema de contribuição através da plataforma VINDI, a mesma utilizada pelo site Outras Palavras, nosso próximo arranjo que será analisado.

\section{Outras Palavras}

Entre todos os arranjos, o Outras Palavras foi o que tivemos mais dificuldade no acesso às informações. A dinâmica do arranjo, as mudanças enfrentadas no mesmo período da pesquisa como as ocorridas no quadro pessoal e a própria mudança de endereço da redação fizeram com que o método utilizado fosse constituído centralmente pela análise da amostragem do conteúdo produzido pelo arranjo, a análise de discurso e a atividade linguageira sobre o trabalho (NOUROUDINE, 2002).

Através da linguagem sobre o trabalho e como trabalho ${ }^{64}$ buscamos apreender o ponto de vista do trabalhador e, consequentemente, os conflitos, valores e normas acionados para realizar a atividade laboral constituintes de o sentido do trabalho.

Fundado no marco do final do segundo governo de Luiz Inácio Lula da Silva, em 2009, o arranjo foi constituído em meio ao cenário do crescimento do país, aumento do uso da internet e a disseminação dos smarthphones e os perfis nas redes sociais. Nesse período, o Ministério da Cultura, com Gilberto Gil, descentralizou os recursos da área para experiências de cultura espalhadas em todo o país.

O programa Cultura Viva abarcou ações como Cultura Digital, Ação Griô, Escola Viva e os Pontos de Cultura, por meio dos quais o site Outras Palavras ganhou musculatura no início de suas atividades.

De acordo com Mariana Reis, a política pública dos Pontos de Cultura “[...] apontam para a articulação de redes sociais como chave para promover o bem-estar das comunidades e para se construir possibilidades de desenvolvimento. (2018, p. 47) Após os Pontos de Cultura

${ }^{64}$ Ver mais no Capítulo I. 
demonstrarem estreito laço com coletivos de comunicação, na gestão de Juca Ferreira à frente da pasta da Cultura foram criados editais específicos, como o Ponto de Mídia Livre, dentro da Rede Cultura Viva, que tratava comunicação e cultura em suas múltiplas dimensões como linguagem, reconhecimento da oralidade na cultura brasileira, códigos aberto das plataformas e das ferramentas de rede, democratização da comunicação e economia solidária.

Da simbiose entre o processo de construção do Fórum Social Mundial, origem da associação Outras Palavras com os Pontos de Cultura, nasce o site:

Outras Palavras tornou-se uma referência importante na galáxia da chamada comunicação compartilhada, ou da mídia livre, abordando uma temática pouco presente nesse universo: o exame crítico da globalização, as novas culturas políticas da autonomia e os movimentos de ocupação das redes e das ruas. O reconhecimento veio logo, em 2010 o site e as plataformas de redes sociais criadas em torno dele receberam, do Ministério da Cultura o Prêmio Ponto de Mídias Livres.

O site foi fundado por Antonio Martins, jornalista do Le Monde Diplomatique, veículo que dava suporte na área de comunicação à organização do Fórum Social de Porto Alegre e, consequentemente, das ideias que sustentavam este espaço político como uma mudança cultural global para construir "Outro Mundo Possível"65.

A gente fez um site que chamava Porto Alegre 2002, depois Porto Alegre 2003, depois Planeta Porto Alegre, que era uma tentativa de fazer um jornalismo que fosse a expressão da diversidade, das novas formas de resistência, de alternativas do Fórum Social Mundial e o Outras Palavras é consequência disso também. (Luiz Graciliano, 2018)

Assim como o Opera Mundi, o Outras Palavras (OP) tem dez anos de fundação e é o leitor o principal apoio de sustentação financeira e editorial, constituindo o centro principal de onde derivam as principais ações em torno das relações de comunicação e de trabalho.

Há uma rede de colaboradores do arranjo composta por cerca de 500 pessoas $^{66}$, a maioria são pesquisadores e professores que contribuem com textos derivados de suas pesquisas, análises de temas que influenciam a conjuntura política ou que apontam para uma perspectiva, uma saída futura de um problema vivido pelo país. Essas pessoas têm afinidade com a linha editorial e entram em contato com o arranjo para propor as suas pautas.

[...] elas que nos procuram, porque nós não temos condição de entrar em contato. A gente entra em contato com algumas, quando a gente identifica algum tema que eles possam contribuir especificamente, mas a grande maioria dos contatos é por própria iniciativa dos colaboradores. Tem um pouco a ver com o perfil dos nossos colaboradores, porque a grande maioria não é jornalista, são pesquisadores, professores, pesquisadores, então, eles propõem textos à medida que eles refletem sobre algum assunto e produzem algum texto. Eventualmente, para alguns, que são mais próximos, a gente propõe um assunto, mas a gente não remunera os

\footnotetext{
${ }^{65}$ Lema das edições do Fórum Social Mundial que aconteceram em Porto Alegre.

${ }^{66}$ Há uma diferença nos números do arranjo entre a nossa entrevista e a realizada pelo CPCT. Em um ano, os números diminuíram. Eram 800 colaboradores, agora são 500; cinco trabalhadores no arranjo, agora são três; 900 pessoas contribuíam financeiramente e atualmente são 800 .
} 
colaboradores. A gente não tem como pautá-los, digamos assim. (Luiz Graciliano, 2019)

A contribuição dos colaboradores não é sistemática ou prevista em uma grade, como descreve Graciliano, embora seja um número considerável de pessoas. Esse fator acarreta um trabalho de articulação de pessoas e pautas no cotidiano do trabalho em torno da informação. Nas palavras do entrevistado: “[...] é uma equipe ${ }^{67}$ de articulação, de proposição de pauta e edição, porque todos os textos a gente edita. A gente faz a curadoria e a edição.”

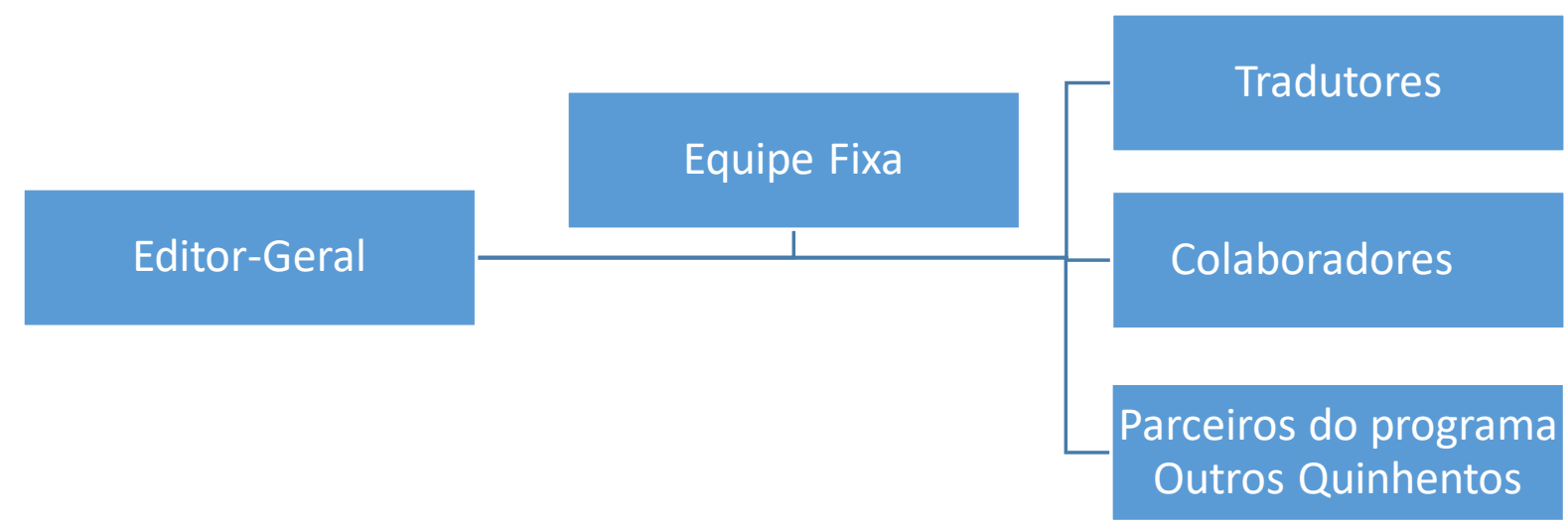

Figura 26 - Organograma de trabalho do Outras Palavras - Fonte: Imagem da autora

A rotina produtiva é organizada através de reuniões de pautas semanais entre a equipe fixa que encaminha variados temas, desde a contabilidade, suporte técnico, contato com os colaboradores e temas para a composição da matéria jornalística. Quando há pessoas que trabalham à distância, o diálogo também é feito pela redação on-line, embora a prática cotidiana seja de tratar presencialmente ou em diálogos bilaterais. De acordo com o entrevistado João Felício, há certa resistência para o uso das ferramentas e espaços de diálogo digitais.

[...] a gente tem uma redação pelo Telegram e aí a gente vai controlando por lá o que sobe, o que não sobe, quem vai traduzir, divide os trabalhos, tal. Então, a gente usa o Telegram, usa lista de e-mail, e a gente usa o Google docs, que até eu já falei para a gente sair e começar o nosso Etherpad. Assim, é uma cultura que tem que se construir. Já foi difícil usar Google docs. Que dirá usar Etherpad, à distância também, quando está longe o Jitsi ou Skype para conversar. (João Felício, 2018)

\footnotetext{
${ }^{67}$ Atualmente a equipe tem três pessoas.
} 
Durante toda a pesquisa, em todos os nossos contatos com o editor do site esse espaço denominado de redação por João Felício, é considerado por Luiz um grupo que não obtém centralidade para a organização do trabalho, já que a redação física era o espaço privilegiado das relações de comunicação. ${ }^{68}$

A divergência entre as duas concepções do uso das tecnologias no trabalho nos evidencia um duplo tensionamento. O primeiro é se Luiz Graciliano não considera trabalho o que ocorre no grupo virtual; e o outro é acerca da "cultura" que é preciso construir entre os membros do arranjo. Será que é preciso mesmo fazer todo processo on-line, ficar horas e horas conectado, usar o editor de texto compartilhado, fazer as reuniões à distância?

A atividade de comunicação e trabalho, como já apontamos anteriormente no Capítulo I, são atividades humanas cuja relação dialética entre ambas as tornam unas e ao mesmo tempo distintas quando relacionadas à realização do trabalho concreto do ser humano. As relações de comunicação articulam o trabalho e, segundo Lacoste (2005), desenvolvem as lógicas de operacionalização, a gestão de conhecimentos, estrutura coletivos, transmite instruções, prescreve e renormatiza o próprio trabalho.

Portanto, se o grupo agrega os profissionais do arranjo e há circulação de comunicação entre eles para a realização do trabalho, não pode ser visto fora da rotina produtiva, mas sim como componente desse processo.

Por outro lado, há nas gerações mais jovens certo determinismo tecnológico nas relações sociais estabelecidas. O uso das tecnologias de informação e comunicação tem provocado mudanças significativas quanto aos vínculos entre as pessoas. Uma evidência é, segundo dados do Comitê Gestor da Internet no Brasil, o brasileiro ficar, em média, nove horas e 14 minutos conectado à internet. ${ }^{69}$

Contudo, além do espaço virtual e social de organização do trabalho, o uso das tecnologias é parte do fazer jornalístico. Primeiramente porque o arranjo se constituiu, conforme Nicole Mendes relata "[...] em uma época que tinha muitos blogs alternativos e todo mundo tinha um blog para se expressar e era a nova mídia e que as pessoas criavam sites e blogs e essa comunicação era nova, tinha influência de softwares livres."70

\footnotetext{
${ }^{68}$ Diante desse argumento, não tivemos acesso ao espaço virtual de trabalho do arranjo.

${ }^{69}$ Ver mais em https://cetic.br/pesquisa/domicilios/indicadores.

${ }^{70}$ Esse tema era bastante presente nas edições do Fórum Social Mundial.
} 
Há recursos tecnológicos desde a pesquisa, apuração e curadoria de conteúdo até a distribuição. A seção Outras Mídias do arranjo é organizada através do feed $^{71}$, ferramenta de notificação sobre a atualização de um site através de assinatura; o desenvolvimento de tecnologias e o seu custo também a possibilidade de diversificação das linguagens, fazer vídeo, peças de designer, materiais radiofônicos. A metrificação é feita somente através dos dados das plataformas (Facebook, Google, Instagram e Youtube), embora não haja produção de conteúdo direcionada por essas métricas.

Para João Felício, a decisão de não usar a mensuração para produção das pautas não é uma opção política, mas sim falta de recurso e investimento nessa área. O papel das métricas, segundo o entrevistado, é de identificação do perfil do leitor. Em suas próprias palavras:

\begin{abstract}
Você consegue ir pegando perfis cada vez mais definidos, cada vez mais granulados, em grande parte a partir de análise de métricas e a partir daí você fala "ah, tem perfil de leitor, se interessa mais por tal coisa, etc. e tal" e você pode direcionar isso para criar produtos de informação, seja matéria, vídeo ou infográfico, mas direcionado para cada tipo de perfil que você queira atingir. (João Felício, 2018)
\end{abstract}

A crítica de Felício é ao parâmetro do uso destas tecnologias do que chamou de "meios de comunicação hegemônicos e de direita neofacista", os quais estão "lutando com laser, enquanto a mídia alternativa utiliza arco e flecha."

Não é de hoje que as corporações de mídia adotaram a mensuração em seu processo produtivo. No Brasil, há medidores como o Instituto Brasileiro de Pesquisa e Opinião (IBOPE), fundado em 1942. Os jornais impressos medem a tiragem de exemplares e calculam o número médio de leitores por exemplar, além de outros métodos utilizados como, por exemplo, pelo Instituto Verificador de Comunicação. Os investimentos em publicidade eram articulados a esses números mostrados no processo de verificação de audiência.

Com a internet, o principal ativo para atrair investimentos na internet mudou. Não é somente a quantidade da audiência, mas sim a especificação do público alvo. A propaganda de uma joia chega para o público com poder aquisitivo para comprá-la de forma mais rápida pela internet devido ao uso de dados sobre as experiências das pessoas na rede.

A migração dos recursos para a internet tem influenciado no processo de monetização e a cultura do clique. Quanto mais cliques, mais registros e informações do perfil do público e a geração de indicadores que definem a publicidade.

\footnotetext{
${ }^{71}$ Rich Site Sumary (RSS 1.0) ou Really Simple Syndication (RSS 2.0) são os formatos de distribuição mais utilizados atualmente.
} 
Outro fator importante é a interferência dos dados e a busca por cliques na atividade jornalística. Anderson (2011, p. 558) concluiu que a mensuração "[...] moldou o julgamento [...]" da seleção de notícias e a determinação da pauta quanto à “[...] geração de visitas para os sites.”

O equilíbrio entre o uso dos dados e a autonomia do jornalista reside na concepção da notícia como mercadoria ou como geradora de uma visão de constituição de conhecimento através do jornalismo.

O uso de softwares pode ser empregado como instrumento do jornalismo sem se deixar ser conduzido pela lógica comercial da notícia, porém utilizando estatísticas para aprofundar temas que são pleiteados pelo público leitor, sem neutralizar essas ferramentas e perceber a própria ideologia a que está relacionada no contexto mais amplo.

Como podemos observar, há diferentes portas de entrada da pauta, contudo a que se destaca é a participação dos colaboradores que se dá através de e-mail e telefone. Conforme Luiz Graciliano, seria “[...] uma situação caótica organizar um grupo com 500 pessoas.”

Vejamos o percurso da produção jornalística: 


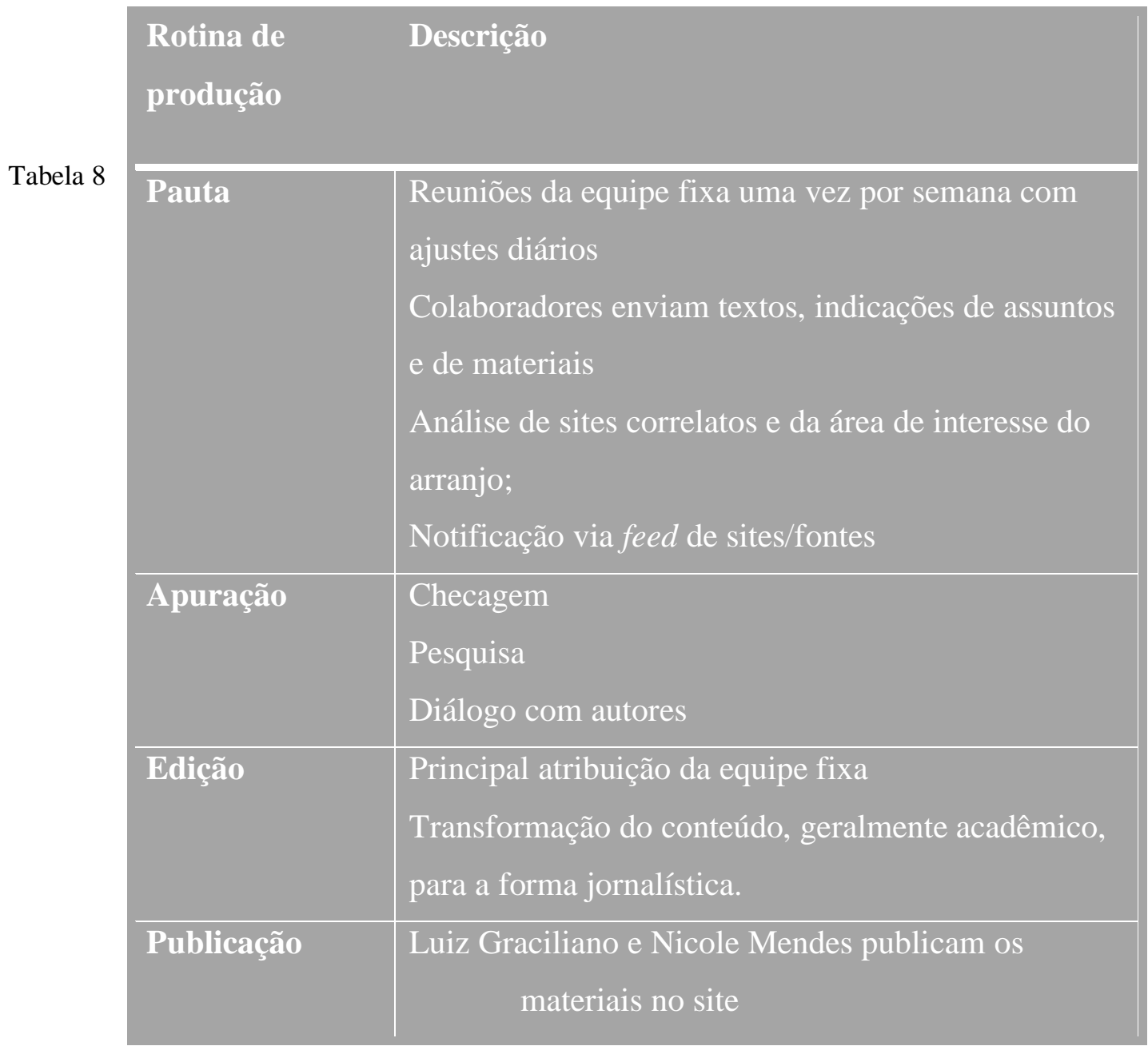

Caminho da produção jornalística no Outras Palavras

Após a seleção da pauta, o principal trabalho é de edição do texto ou do vídeo. As matérias em formato audiovisual são produzidas pela equipe fixa a partir do encaminhamento da reunião de pauta e com o uso de softwares cada vez mais multiplicados para usar no celular, tablet ou computador.

Já quanto ao texto, a pesquisa é uma etapa fundamental visto que o conteúdo predominantemente é acadêmico. Para João Felício, o jornalismo que o arranjo exerce é de “[...] análise, de opiniões, de artigos, não é hardnews, não são notícias quentes." Concepção corroborada por Luiz Graciliano ao julgar que o espaço do arranjo é de "[...] interpretar os grandes movimentos da conjuntura brasileira."

\section{O jornalismo produzido pelo Outras Palavras}

O objetivo da produção jornalística no arranjo é mergulhar nas causas e consequências de fenômenos para que o leitor possa entender o que passa na vida dele numa visão 
macrossocial. As análises, editoriais e seleção do tema são feitas a partir do mesmo tema do Fórum Social Mundial: “Outro Mundo É Possível”.

A curadoria de conteúdo também é nomeada como uma das atividades jornalísticas. Em momento de excesso de informação que circulam na internet, o curador seleciona, organiza e trata a informação em um contexto definido. Segundo Rosenbaum (2011), a curadoria é composta pela “[...] seleção, organização, apresentação e evolução de elementos informacionais [...]" e essas atividades são essencialmente humanas devido às nuances dos gostos dos diferentes grupos cujas preferências são identificadas por indivíduos e não por computadores que agregam dados sem fazer a mediação e sem a organização qualitativa.

Análise compartilhada por Ramos que aponta a mediação como a principal atribuição do curador:

O curador tem a característica de mediador e esta é uma atividade central na vida contemporânea. Talvez não se trate mais de produzir novas formas, mas arranjá-las em novos formatos, como os artistas contemporâneos, que reprogramam o fazer artístico e não mais compõem formas, mas as programam: em vez de transfigurar um elemento bruto (a tela branca, a argila), eles utilizam o dado. (RAMOS, 2012, p. 20)

O processo de seleção de acordo com Jenkins, Ford e Green é atividade presente no cotidiano das pessoas ao enviar uma foto, um meme ou um link interessante por e-mail a um amigo, ao compartilhar um vídeo ou um endereço de evento.

Para Saad e Raposo (2017, p. 10), entre outras características, a curadoria de conteúdo não é marketing, cópia de informações já disponíveis; ou reunião e compartilhamento de conteúdo de terceiros disponíveis nas redes e não está restrita ao meio digital. Para os autores, curadoria envolve um "[...] conjunto de saberes interdisciplinares; a criação de recortes e contextos ao enorme volume de informações disponíveis sobre um assunto e a visibilidade ao tema de modo adequado às necessidades do público receptor."

Essa mediação é ainda mais necessária em uma relação em que a própria fonte jornalística também é produtora ativa de informações. Novamente aqui podemos perceber que as tecnologias contribuem para que cada vez mais pessoas possam produzir informação de qualidade sem necessariamente ter passado por uma faculdade de jornalismo.

O profissional da comunicação tem o seu papel de mediador confirmado com o uso da mídia para práticas comunicativas específicas em interação determinada, diferente de midiatização que, segundo Hjarvard (2014, p. 24): 
A midiatização diz respeito às transformações estruturais de longa duração na relação entre a mídia e outras esferas sociais. [...] a midiatização preocupa-se com os padrões em transformação de interações sociais e relações entre os vários atores sociais, incluindo os indivíduos e as organizações. Dessa perspectiva, a midiatização envolve a institucionalização de novos padrões de interações e relações sociais entre os atores, incluindo a institucionalização de novos padrões de comunicação mediada.

Quando analisamos o Opera Mundi, identificamos a mesma tensão entre mediação e midiatização quando um dos profissionais relatou a diferença entre a comunicação direta e presencial e o diálogo mediado por um dispositivo comunicacional. Aqui o mesmo tema é abordado sob a dimensão de mudanças estruturais com “[...] novos padrões de comunicação mediada [...]" (idem, p. 25), que se desenvolvem no seio da sociedade, especificamente nas atividades do mundo do trabalho e sobre o papel do jornalista nessas novas relações.

A parcialidade do arranjo e seu lugar no contexto geral do embate de ideias na arena social são declarados em sua política editorial. Após a eleição presidencial, houve uma mudança do site devido ataques e funcionalidade. "O site superou ataques e inaugura novo projeto gráfico. É o início de ampliação editorial, que permitirá debater mais intensamente crise global e brasileira - sem perder a profundidade jamais", anunciou o arranjo no seu endereço na internet. 


\section{§ OUTRASPALAVRAS \\ f 1 으 \\ Q \\ OUtRASPALAVRAS $\mid$ OUTRASMIDIAS | BLOGDAREDAÇÃO | OUTRASAÚdE | OUTROSLIVROS | OUTROSQUINHENTOS}
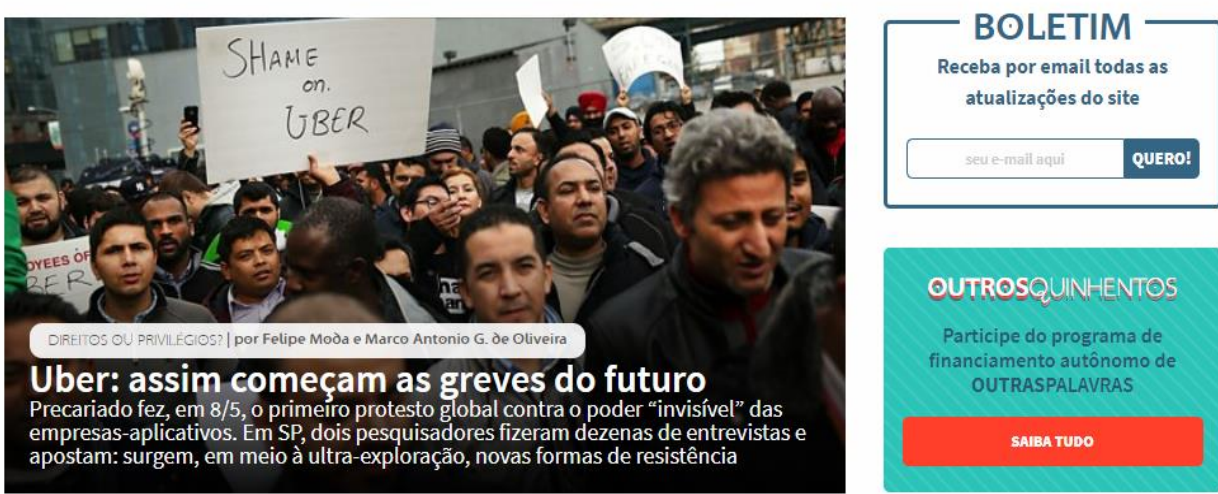

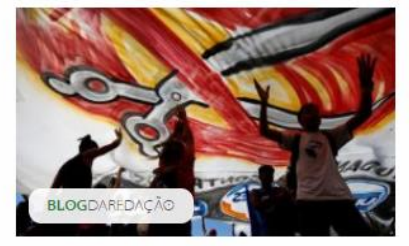

Falta uma esquerda que vá além da negação

Bolsonaro tenta evitar mais cortes desgastantes porque sentiu o trauma das ruas, em 15/5. Está na hora de um programa alternativo, capaz de superar a lógica cinzenta do "aiuste fiscal"

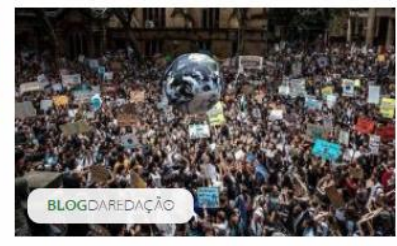

Alerta global: jovens param de novo - pelo clima

Da Índia aos Estados Unidos, do Brasil ao Malawi, mais de 1,6 milhão de jovens, em 2.265 cidades de 125 países, nos cinco continentes, farão nesta sexta a segunda Greve Global pelo Clima

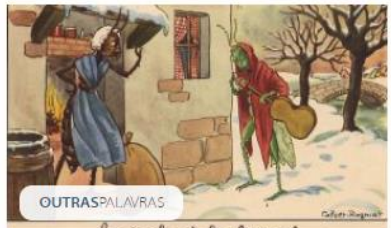

O conto de fadas de Paulo Guedes

Desigualdade cresce, "Superministro" insiste na

desastrosa fábula de "austericídio" fiscal e da privatização de estatais. Não há "boa vontade" do mercado: recuperar o protagonismo do Estadoé

Figura 27 - Reprodução do site Outras Palavras - Fonte: Outras Palavras

O site é organizado por canais que agregam ações e denotam a política do site de parceiros. São denominados como canais: 1) Outras Mídias: agrega pautas que ajudam a construir a do arranjo; 2) Blog da Redação que agrega a produção própria; 3) Outra saúde que se coloca em defesa do Sistema Único de Saúde (SUS) e por sua transformação; 4) Outros Livros com indicação de obras de editoras parcerias, como a Elefante, criada com o apoio do arranjo; 5) OPTV que é o canal do Youtube do site e aglutina a produção audiovisual. Outros Quinhentos é o nome do "programa de financiamento autônomo", como apresenta o arranjo. 
PRINCIPAIS CATEGORIAS

\begin{tabular}{|c|c|}
\hline vídeos Da & PODCASTS \& \\
\hline PÓS-CAPITALISMO & TRABALHO E PRECARIADO \\
\hline MOVIMENTOS E REBELDIAS & CIDADES EM TRANSE \\
\hline DESCOLONIZAÇÕES & FEMINISMOS \\
\hline DESIGUALDADES & INTERNET EM DISPUTA \\
\hline POÉTICAS & CRISE BRASILEIRA \\
\hline \multicolumn{2}{|l|}{ MERCADO X DEMOCRACIA } \\
\hline \multicolumn{2}{|l|}{ INSTITUCIONAL } \\
\hline SOBRE & EQUIPE \\
\hline TRADUTORES & AJUDE A SUSTENTAR \\
\hline CONTATO & SOBRE OUTRA SAÚDE \\
\hline \multicolumn{2}{|l|}{ CANAIS } \\
\hline OUTRASPALAVRAS & OUTRASMÍDIAS \\
\hline BLOGDAREDAÇÃ@ & ○UTRASAÚDE \\
\hline OUTROSLIVROS & OUTROSQUINHENTOS \\
\hline OUTROS BLOGS & REDE PARCEIRA \\
\hline $\begin{array}{l}\text { PAZ } \\
\text { E BEM }\end{array}$ & 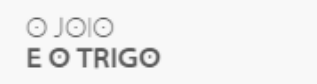 \\
\hline $\begin{array}{l}\text { LUIZA } \\
\text { SANSÃ॰ }\end{array}$ & $\begin{array}{l}\text { DE } \odot L H \odot \\
\text { NOS RURALISTAS }\end{array}$ \\
\hline $\begin{array}{l}\text { ALCEU } \\
\text { CASTILH॰ }\end{array}$ & REDES SOCIAIS \\
\hline $\begin{array}{l}\text { TERRA } \\
\text { EM TRANSE }\end{array}$ & f \\
\hline $\begin{array}{l}\text { PLANTAR } \\
\text { O FUTUR० }\end{array}$ & ACESSIBILIDADE \\
\hline
\end{tabular}

Figura 28 - Fotografia da organização do site - Fonte: Outras Palavras (2019)

Durante o período de coleta foram publicadas três matérias:

\begin{tabular}{|l|l|l|l|}
\hline Data & Editoria & Título & Descrição \\
\hline 6 de janeiro & Outra Saúde & $\begin{array}{l}\text { Redes sociais - programadas } \\
\text { para viciar }\end{array}$ & $\begin{array}{l}\text { Entrevista editada } \\
\text { por membro da } \\
\text { equipe fixa em } \\
\text { formato podcast }\end{array}$ \\
\hline 7 de janeiro & Pós-Capitalismo & $\begin{array}{l}\text { Cultura Livre no Sul Global - } \\
\text { um manifesto }\end{array}$ & $\begin{array}{l}\text { Artigo de } \\
\text { Leonardo Foletto, } \\
\text { editor do site } \\
\text { Baixa Cultura }\end{array}$ \\
\hline 7 de janeiro & Sem categoria & $\begin{array}{l}\text { Prefiro não do Estado } \\
\text { Islâmico ao bolsonarismo }\end{array}$ & $\begin{array}{l}\text { Artigo de Priscila } \\
\text { Figueiredo }\end{array}$ \\
\hline
\end{tabular}

Tabela 9 - Relação de matérias coletadas no arranjo- Fonte: A autora (2019) 
Como podemos observar, foram dois artigos e uma produção em áudio com temas que não são recorrentes nas corporações de mídia, elaborados pela equipe fixa e por colaboradores.

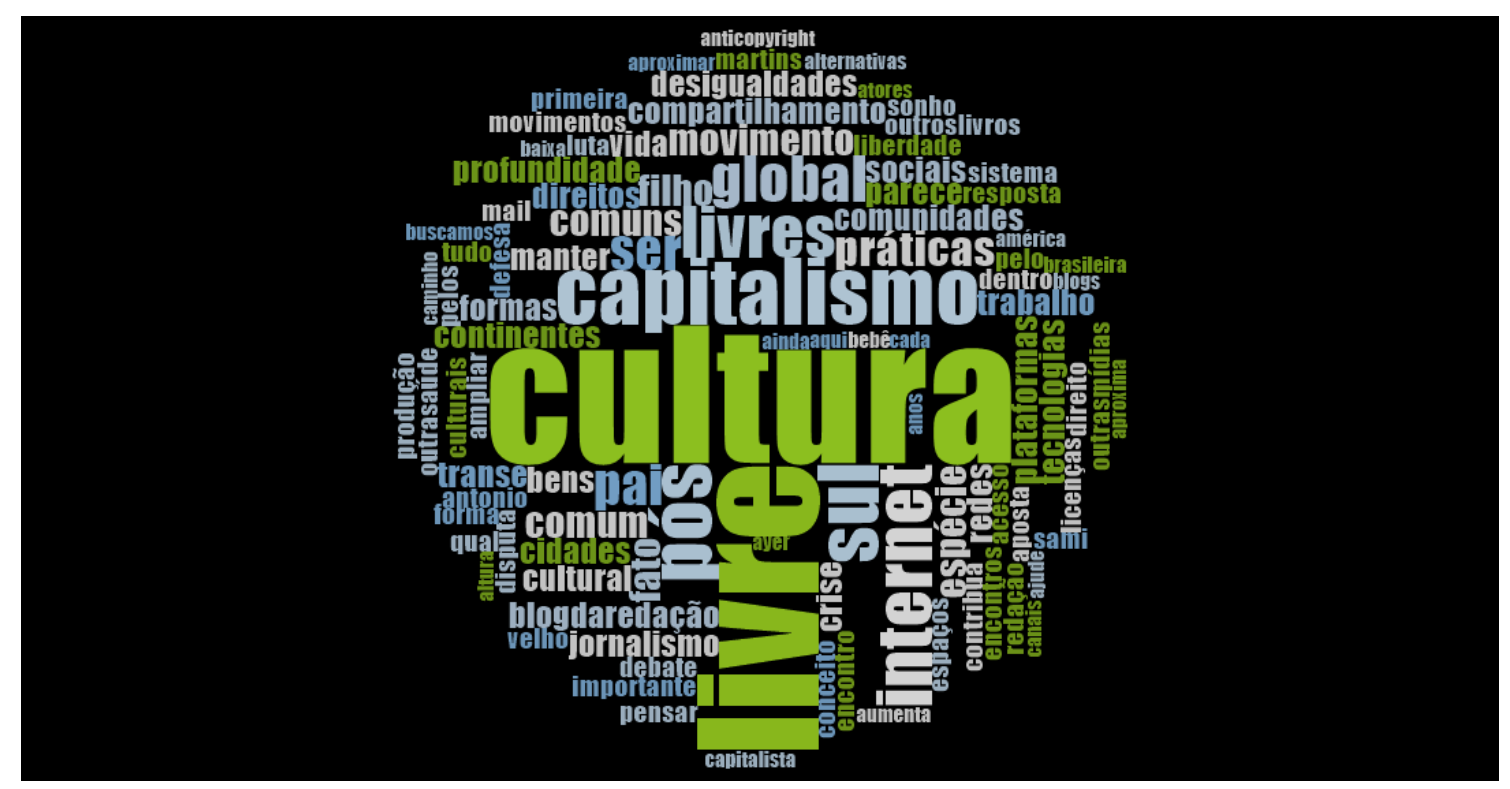

Figura 29 - Nuvem de palavras-chave encontradas nas matérias coletadas - Fonte: NVivo

O posicionamento do arranjo é evidente em se colocar como "jornalismo de profundidade". As palavras "cultura", "capitalismo", "internet", "global” refletem os assuntos selecionados para apresentar ao leitor, assim como "importante", "pensar", "debate” buscam se estabelecer no campo que estimula a reflexão através de artigos de opinião.

Colocar-se com clareza como espaço destinado para a discussão e apresentação de informações que não são facilmente encontradas mesmo na comunicação alternativa é articulado com a contribuição material de pessoas identificadas com essa pauta.

O programa de financiamento Outros Quinhentos é hoje a principal fonte de recursos que sustenta o arranjo.

Diferentemente de outros veículos de comunicação, a troca entre a pessoa que contribui e o arranjo não é o acesso ao conteúdo produzido porque a informação criada é totalmente acessível, mas sim sorteios de ingressos para teatros, cinemas, desconto em editores, sorteios de livros e outros produtos de parcerias estabelecidas para esta finalidade. Conforme descreve João Felício, Outros Quinhentos é: 
[...] o programa de autofinanciamento do Outras Palavras, que visa conseguir doações de pessoas físicas. A gente evita o termo assinatura, porque nosso conteúdo é aberto. Então, o cara não está pagando para ter acesso ao conteúdo, o cara está pagando porque ele acredita na necessidade do projeto e como contrapartida desse apoio que ele dá para o projeto, a gente cria uma rede de vantagens para ele em restaurante, desconto em livros, entrada de cinema, sorteios semanais, baladas, produtos orgânicos, e aí a gente tenta fazer essa rede ser nacional, mas a maioria dos serviços que a gente oferece estão concentrados em São Paulo e Rio de Janeiro. Mas assim, sorteio de livro é nacional, sorteio de ingresso de cinema é nacional, então a coisa está indo. Aí, de acordo com a quantidade de dinheiro que você doa mensalmente você tem descontos menores ou maiores em serviços e produtos. (João Felício, 2018)

As empresas anunciam no site em troca da concessão de produtos e serviços ou descontos para os leitores de Outras Palavras.

As doações são feitas por um programa de gerenciamento de contribuição chamado VINDI $^{72}$ e podem ser de R\$ 15 até R\$ 2 mil. Quem faz a doação mínima ganha como contrapartida uma ecobag, um livro, descontos de até $20 \%$ nas editoras parceiras. A diferença entre o apoio mínimo e máximo são os descontos na compra de livros que chegam até $70 \%$.

O valor arrecadado (atualmente cerca de R \$ 15 mil mensais) é responsável por $80 \%$ da sustentação do arranjo e serve para pagar "[...] uns dez itens de despesa, entre os quais cinco salários, o resto é aluguel da sala, aluguel da banda na internet, despesa de escritório, despesa de transporte [...]", descreve o entrevistado do Outras Palavras na pesquisa do CPCT:

[...] a gente inventou uma forma de oferecer espaço do que a gente chama de antipropaganda. É um espaço publicitário não mercantil. Nós temos um público leitor relativamente grande, não é comparado aos grandes portais nem de sites que são mais de notícias, porque a gente não é de notícia. Mas são umas dez mil pessoas por dia. É um público muito caracterizado. Então, por exemplo, produtores culturais e da economia solidária encontram no Outras Palavras um veículo para chegar no público deles. (Entrevistado do Outras Palavras na pesquisa do CPCT, 2018)

O mote da campanha de financiamento é o "[...] apreço pela profundidade, rejeição ao panfleto, esforço para debater a globalização, as alternativas, os temas ligados à emergência de uma nova cultura política. Queremos continuar a acompanhar a conjuntura brasileira, num período tenso e decisivo." (site Outras Palavras, 2017)

Nesse terceiro capítulo, através do recorte metodológico de examinar os arranjos de comunicação que trabalhavam no Ateliê do Bixiga, procuramos identificar as características estruturais das relações de produção e comunicação dos jornalistas que atuam no espectro da comunicação alternativa em cada contexto específico. Podemos perceber que o espaço social

\footnotetext{
${ }^{72}$ Plataforma de pagamento recorrente.
} 
do trabalho do jornalista se dá no ambiente somente virtual, como no Jornalistas Livres, que não política de manutenção e se apoia no trabalho voluntário de uma ampla gama de colaboradores em torno do jornalismo em rede em que o leitor também ocupa em momentos diferentes o papel de fonte ou escritor da matéria. Da mesma forma de comportamento do leitor do site Outras Palavras, que conta com mais de 500 pessoas que contribui com financiamento e textos, na maioria acadêmicos, para o veículo que organiza o seu processo produtivo numa sede física.

A diferença entre o trabalho do jornalista organizado na sede física e digital fica nítida com a observação feita no Opera Mundi, que utiliza os dois ambientes. O site, entre os observados, foi o que mais postou matéria própria no período de coleta sobre temas internacionais, assunto sobre o qual especializado. Esse também é o tema principal, mas com viés humanista, da Agência Pressenza, que busca fórmulas mais complexas de organização ao mesmo tempo em que presta serviços na área de produção de informação para outras empresas para garantir a sua sustentação.

Dadas as especificidades, o próximo e importante passo é questionarmos em quais evidências empíricas e teóricas os arranjos se aproximam e se diferenciam. O cenário geral da crise desencadeada em 2007/2008, o seu impacto no mundo do trabalho do jornalista, no próprio jornalismo e nas formas de resistência da comunicação alternativa são os eixos do encontro dos nossos arranjos sobre o que refletiremos no próximo capítulo. 


\section{CAPÍTULO IV}

Onde as iniciativas se encontram 
Após aprofundarmos as especificidades de cada arranjo econômico alternativo, agora vamos nos ater às questões que permeiam a constituição dos arranjos alternativos, para entendermos como tais especificidades influem nas condições de produção e no jornalismo realizado por eles. São aspectos gerais resultantes dos choques de classes, das transformações no mundo do trabalho e da contínua reestruturação capitalista. Também há outros fatores singulares, a exemplo da renovação das práticas jornalísticas nesse contexto de embates e resistências.

As categorias que aprofundaremos emergiram do próprio processo de pesquisa e das marcas no discurso dos entrevistados que nos conduziram e alertaram até adquirir a estatura de vertentes estruturais para análise.

Com base na análise de Discurso (PÊCHEUX, 1988; ORLANDI, 2007; VOLOCHINOV/BAKHTIN, 2014), que articula o contexto da situação de fala aos elementos históricos, sociais, culturais e ideológicos dos enunciados, interpretaremos os discursos dos entrevistados. Compreendemos que os efeitos de sentidos estão materializados e refletidos no discurso, que é polissêmico, plurissignificativo e heterogêneo (BAHKTIN, 2014; AUTHIERREVUZ, 2004). O sujeito enunciador é marcado por uma situação de fala dada e concreta, não podendo ser dessa forma um sujeito abstrato regido por seu "interior" ou, metafisicamente, no subjetivismo abstrato.

Ao utilizar a análise de discurso, buscamos alcançar os efeitos de sentidos do discurso e considerar para tal objetivo a formação discursiva que determina o que pode ou não ser dito, representando na linguagem as formações ideológicas. Os sentidos, de acordo com Pêcheux (1988, p. 161), se constituem em “[...] cada formação discursiva, nas relações que tais palavras, expressões ou proposições mantêm com outras palavras, expressões ou proposições da mesma formação discursiva., ${ }^{, 73}$

Brandão (2012), ao distinguir a epistemologia clássica representada pela tendência "representativa" de nova maneira a ver a língua como dispositivo de "demonstração", posiciona a linguagem como espaço de constituição da subjetividade do sujeito. O discurso desse sujeito é marcado por outros enunciadores e discursos aos quais que Bakhtin (2014, p. 102) chama de "fios dialógicos vivos". Nas palavras do próprio autor:

\footnotetext{
73 De acordo com Helena Nagamine Brandão (2017, p. 42), formação discursiva é o lugar específico da constituição dos sentidos e junto com a condição de produção e formação ideológica formam a tríade básica nas formulações teóricas da análise do discurso.
} 
Um enunciado vivo, significativamente surgido em um momento histórico e em meio social determinados, não pode deixar de tocar em milhares de fios dialógicos vivos, tecidos pela consciência socioideológica em torno do objeto de tal enunciado e de participar ativamente do diálogo social. (/ VOLOCHINOV/ BAKHTIN, 2014, p. 102)

Compreender os diferentes discursos foi fundamental para notar a menção "Folha de S. Paulo’ reiterada 18 vezes por Mônica Galvão ao se referir a um modelo de jornalismo ou organização do Jornalistas Livres. Um exemplo explícito é o núcleo administrativo do arranjo - chat Vegetariano ${ }^{74}$ - ser comparado com o da Folha:

No caso da Folha, a Folha tem por exemplo a redação, a hierarquia da redação, mas existe um outro setor que é a secretaria administrativa que é quem compra a passagem para o cara viajar, aluga o escritório que vai ser a sede sucursal do Rio. É quem tenta viabilizar as coisas. (Mônica Galvão, 2018)

A migração de jornalistas experientes das empresas monopolizadas para os arranjos alternativos faz com que as práticas se misturem, ou seja, ações que eram normativas nas grandes redações começam a fazer parte do contexto da mídia alternativa na forma de produção do jornalismo e nas relações de produção. Esses profissionais passaram boa parte da sua vida profissional dentro da lógica produtiva de uma corporação de mídia e essas práticas podem ser repetidas e reforçadas no cotidiano do coletivo jornalístico.

Da mesma forma como o discurso fez emergir algumas contradições como apontamos anteriormente, também nos fez identificar a percepção dos sujeitos sobre o trabalho, a crise do jornalismo e o conceito de mídia alternativa. Esses elementos revelam potencial material para a generalização possível e indicações empíricas e teóricas para fornecer uma linha de raciocínio capaz de evidenciar outras facetas sobre as relações e condições de produção do jornalismo em arranjos alternativos. Passemos a discutir então esses aspectos.

\section{Condições de produção dos jornalistas em arranjos alternativos de comunicação}

A "classe-que-vive-do-trabalho" amarga os reflexos da crise estrutural do capital de 2007/2008, como, por óbvio, aconteceram em todas as "crises cíclicas do sistema". (MARX, 2017c) Os colapsos do sistema resultam em inovações tecnológicas, novas formas de produção, circulação de mercadorias, necessidades de novos serviços e alterações da divisão social do trabalho na cadeia produtiva. Na crise do keynesianismo, em 1973, por exemplo, a

\footnotetext{
${ }^{74}$ Ver mais no Capítulo 3.
} 
empresa italiana Benetton centralizou o seu capital, descentralizou a produção em diferentes países e estabeleceu o controle em rede da produção.

O sistema de produção toyotista, após a Segunda Guerra Mundial, foi a saída no Japão para substituir a produção em massa de artigos estandardizados pelo consumo personalizado, produzido por um sistema flexível, mais enxuto e transnacionalizado. Diferentemente da base fordista-taylorista, cuja participação criativa dos trabalhadores era neutralizada com a ultra especialização, concentração em seu posto e pequeno espaço de trabalho em que o trabalhador precisa corresponder à cadência da máquina que impunha o ritmo de produção, o sistema de produção japonês mobiliza todas as habilidades e subjetividades individuais e coletivas do trabalhador, que antes pertenciam a uma estrutura vertical e centralizada.

A racionalização toyotista de produção passa a ser regida por um sistema de “acumulação flexível” (HARVEY, 1992) com a fusão de funções e postos de trabalho, exigindo da classe trabalhadora multifunções e polivalência, sendo este o modo atual de expropriação do capitalismo.

As matrizes que sustentam o toytismo são evidentes no trabalho do jornalista nos arranjos alternativos que pesquisamos e que também foram constatadas no livro As mudanças no mundo do trabalho do jornalista (FÍGARO; NONATO; GROHMANN, 2013). Cada cobertura específica, em que é aberto um chat pelos membros do Jornalistas Livres para organizar o trabalho, é um projeto jornalístico específico. Também é a lógica de projetos que permite aos ativistas da Agência Pressenza organizar um outro arranjo para vender a sua força de trabalho. A cada "projeto", ou seja, serviço fechado é mobilizado um grupo de pessoas com capacidades específicas para desempenhar as ações exigidas.

A palavra "projeto" é utilizada no lugar de "emprego/serviço temporário" sem as garantias sociais. Trabalhar por projeto significa que ao término as relações de trabalho serão encerradas. O serviço é executar o projeto que tem tempo para começar e acabar. Não é à toa que há uma miríade de oferecimento de plataforma de projetos, como o Trello, que vimos no capítulo anterior.

Outra baliza toyotista intrínseca às atividades jornalísticas é a polivalência. Nos veículos alternativos analisados, as exigências de um profissional "multitarefas" são maiores devido à falta de estrutura e organização. A polivalência é uma das facetas do trabalho precarizado ao mesmo tempo que é evidência da alteração dos meios de produção e a 
consequente transformação dos processos produtivos. Além das fusões de postos de trabalho do modelo de produção, o uso das tecnologias de informação e comunicação reflete em mudanças nas profissões com o desaparecimento de funções como o copy-desk e o surgimento de outras atribuições que fazem com que o jornalista realize novas tarefas que não são enquadradas profissionalmente.

Observamos esse ponto em todos os arranjos pesquisados cujos profissionais realizam diferentes funções e até mesmo criando atribuições no processo de realização do jornalismo, como veremos adiante.

Eu faço meio tudo, mas, principalmente, o que faço, atualmente, são os vídeos, mas também faço designer... Como são só três pessoas atualmente, a gente faz tudo. Faço as contas, a contabilidade, faço designer do site. [...] Faço tudo que precisar, eu faço. Eu já escrevi também em uma época, mas nunca mais. (Nicole Mendes, 2019)

Assim como Nicole Mendes, todos os jornalistas entrevistados trabalham em mais de uma especialização e a percepção é de fazer tudo que está no alcance. Mesmo sem ter conhecimento suficiente o profissional pesquisa no Youtube, pergunta para outras pessoas que sabem, muitas vezes convida um especialista sobre determinado assunto e promovem cursos ou "imersões" quando fica muitas horas seguidas aprendendo junto.

O trabalhador multitarefa e polivalente também é um fetiche do capital. A polivalência não significa ter muitas habilidades e conhecimentos, mas sim significa que o profissional pode ser responsável por diferentes funções e postos, como vimos a descrição de uma das jornalistas cujo apelido é polvo na redação por cumprir diferentes funções, ter várias mãos e fazer tudo ao mesmo tempo.

A outra faceta de fazer várias funções ao mesmo tempo é a precarização das relações do trabalho. O jornalista tem que cumprir diferentes funções porque há um número diminuto de profissionais, por isso o mesmo profissional paga as contas, desenha o site, edita e grava vídeos. Atuar profissionalmente sem enquadramento e atribuições específicas contribui com o esgotamento físico e mental do jornalista, que longe de ter condições sociais garantidas pelo Estado tem a sua perspectiva de trabalho encurtada. Nos lugares em que o trabalho é voluntário esse é um dos fatores de alta rotatividade dos participantes do coletivo ou veículo.

Nos setores de comunicação no Brasil, a precarização iniciou já na década de 1990 com o processo de desestatização de Fernando Collor de Melo e Fernando Henrique Cardoso. Serviços que hoje são essenciais e altamente lucrativos foram desnacionalizados, como o de telefonia, dentro do projeto neoliberal ditado pelas potências internacionais. 
E eu fui a primeira leva de terceirização da Folha, desde 1998. Por isso que eu falo: hoje, toda essa questão de precarização para mim vem desde 1998, de não ter INSS, do valor que ganho, de ter que vender o almoço para pagar a janta. Isso trabalhando para uma empresa grande. Hoje sou 'quarteirizada'. Trabalho para uma empresa terceirizada, sou 'quarteirizada' em escala. Essa precarização no nosso meio e entre os designers é mais antiga, o buraco é mais embaixo. (Ana Cláudia da Silva, 2018)

A realidade dentro das empresas de comunicação, quanto aos direitos profissionais, não é muito diferente da encontrada nos arranjos alternativos de mídia. A falsa concepção liberal, à qual coloca o jornalista como um trabalhador intelectual, contribuinte com as suas ideias "iluminadas" para a sociedade, tem denominado esse processo de "proletarização" do profissional da notícia. Cabe lembrar que o jornalista, no início da profissão, não recebia salário, não tinha piso salarial e, muitas vezes, seu pagamento era um vale, um eletrodoméstico ou outra mercadoria. Essa situação só mudou com a instituição do salário e valorização do profissional no jornal Última Hora, de Samuel Wainer, em $1953 .{ }^{75}$ Ou seja, a maior dignidade do jornalista foi alcançada com os direitos trabalhistas, nesse sentido, o jornalista foi e é um trabalhador.

Outro eixo do toytismo trata de "[...] envolver a classe trabalhadora em sua forma mais profunda de alienação e estranhamento.” (informação verbal ${ }^{76}$ ) Para isso, o sistema kaizen e os Círculos de Controle de Qualidade utilizam os próprios trabalhadores para apontar as melhorias necessárias do processo de produção ao mesmo tempo em que os conflitos e as divergências são minimizados e usados como potencial criativo que alavanca a produção.

Além de sequestrar a subjetividade individual, o engajamento alarga as jornadas de trabalho, fazendo com que o tempo todo seja hora de pensar e se debruçar sobre o trabalho. No fordismo-taylorismo, as estruturais gerenciais davam ao supervisor a responsabilidade pelo aumento da produtividade por meio da observação e do ajuste de forma unilateral dos métodos. Já no sistema de produção japonês, a qualidade do trabalho é de responsabilidade de cada trabalhador que dessa forma se engaja e "veste a camisa" da empresa ao mesmo tempo em que fiscaliza o seu trabalho e o do outro e não ganha para isso.

Eu fazia todo o meu trabalho das até às $22 \mathrm{~h}$ e das $22 \mathrm{~h}$ até a meia noite eu ficava fazendo aquilo que era legal. Então, eu já era engajada mesmo no serviço na Folha de S. Paulo. Eu ficava pensando: alguma coisa precisa me dar prazer nessa $\mathrm{p}^{*}$. E eu tenho que aprender e evoluir com essa parte que me dava prazer, porque a rotina de trabalho era chatíssima, um pé no saco. (Ana Cláudia da Silva, 2018)

\footnotetext{
${ }^{75}$ Ver mais sobre o assunto em Jornalistas Românticos, de Alzira de Abreu, e artigo de nossa autoria em http://portalintercom.org.br/anais/nacional2017/resumos/R12-0483-1.pdf.

${ }^{76}$ Ricardo Antunes, Informação coletada em sala de aula na disciplina Sociologia do Trabalho.
} 
É notória a diferença entre vender a sua força de trabalho e atuar voluntariamente por uma causa e por algo que se acredita ser importante para determinados objetivos, mesmo que seja por capital simbólico e reconhecimento, como podemos verificar nos casos dos partícipes da Agência Pressenza, Jornalistas Livres e Outras Palavras. Mesmo aqueles que têm uma relação mediada por pagamento de horas trabalhadas com o recebimento de salário, acreditam que realizam um tipo de jornalismo articulado com a sua visão de mundo com mais liberdade e autonomia.

Contudo, a naturalização de jornadas alargadas como relatado pela entrevistada do Jornalistas Livres $^{77}$ - que enquanto não desliga o celular não para de trabalhar ou para Ana Cláudia da Silva que relata que muitas vezes não consegue ir ao banheiro sem trabalhar ao celular -, representa certa inconsciência do que significa o tempo de não trabalho para a saúde do jornalista.

Até mesmo em livros de autoajuda, do tipo "se organize para trabalhar" e de "estímulo à alta produtividade", há apontamentos para o perigo da jornada extensa. Sylvia Ann Hewlett, convidada ilustre de grandes empresas para falar de trabalho e produtividade, publicou um artigo na Harvard Business Review junto com Carolyn Buck Luce sobre os perigos das altas jornadas de setenta horas, denominado pela autora como "empregos extremos".

No artigo, as duas executivas do mercado demonstram que a maioria dos participantes da pesquisa, $66 \%$, não se sentem explorados, mas sim exaltados. As jornadas excessivas são obstáculos para as mulheres que não conseguem trabalhar todo esse tempo por terem jornada dupla ou tripla conciliando estudos, tarefas domésticas e cuidados dos filhos.

As autoras identificam também "seis fatores estressantes" da intensidade de trabalho que são motivadoras de depressão e esgotamento. São eles: rigidez combinada com imprevisibilidade; ritmo rápido e prazos curtos; disponibilidade integral; viagens constantes; eventos de trabalho fora da jornada padrão e o alto número de interrupções durante o tempo de trabalho por "dispositivos de comunicação". De acordo com as autoras, o trabalhador "[...] se dedica em média três minutos de atenção a qualquer tarefa antes de uma interrupção e esse fato elimina qualquer esperança de serenidade. (2006, p. 55)

\footnotetext{
${ }^{77}$ Entrevistada para pesquisa do Centro de Pesquisa em Comunicação e Trabalho, pesquisa citada ao longo da dissertação.
} 
A divisão entre tempo de trabalho e não trabalho ${ }^{78}$ é borrada em toda a cadeia produtiva do capital, não só para os arranjos alternativos como observamos. Pietro Basso (2018, p. 213) cita em seu livro o relatório da Fundação Europeia de Dublin, que destaca os “[...] riscos de fusão e sobreposição do trabalho e da vida privada, do tempo de trabalho e do tempo livre, do local de trabalho e de casa."

No teletrabalho, essa realidade inclui ainda a impossibilidade de negociação com o empregador, o baixo salário, a ausência de proteção social, doenças por trabalho repetitivo, estresse, além de ficar à margem do trabalho coletivo e não poder discutir aspectos de suas atribuições. Sem os limites entre tempo de trabalho e não trabalho, a vida fora do trabalho se transforma em extensão do trabalho sem sentido e regida pelas relações que se dão no mundo do trabalho, sendo o tempo livre apenas para recuperar a fadiga do desgaste físico e intelectual e em muitas vezes nem isso é possível.

Desse modo, é importante que os arranjos alternativos reflitam sobre o trabalho e o sistema em que estão inseridos, dissolvendo o estranhamento e promovendo um sentido no trabalho para que fora dele também seja capaz de haver sentido na vida enquanto sujeito que age sobre sua realidade.

Os arranjos analisados reivindicam fazer um jornalismo contra o monopólio da comunicação (Outras Palavras), posicionar-se como humanista (Agência Pressenza), defender os direitos humanos e o jornalismo (Jornalistas Livres) e almeja falar por parte da esquerda internacional (Opera Mundi). Colocam-se como alternativa à lógica das grandes corporações de mídia e, portanto, podem ser inovadores quanto às suas relações de produção, mas devem atentar para os sentidos do trabalho e para o trabalho ter sentido para a vida.

A organização nesses arranjos é mais permeável à sociedade. Dos quatro, apenas o Opera Mundi tem a estrutura verticalizada e similar à redação tradicional. Os outros três têm relações mais horizontais cujos membros cumprem atribuições diferenciadas. Ser organizado e transparente é essencial para a permanência, periodicidade e produção dos arranjos. A discussão sobre a organização do arranjo onde o trabalho é voluntário e militante carece ser feita com o conjunto dos membros, em reuniões amplas para não alienar a relação com o jornalista e o próprio trabalho social.

\footnotetext{
${ }^{78}$ Ricardo Antunes utiliza a expressão "tempo livre" no livro Os sentidos do trabalho. Deparamos também com a denominação de tempo de família que não usaremos por entender que as relações fora do tempo de trabalho não são necessariamente à família, visto que os proletários já não têm tanta prole assim, inclusive pela pressão dos empregadores.
} 
Alargar a jornada e apropriar-se do trabalho intelectual foram as saídas proeminentes da crise de 1973 para gerar mais valor com a expropriação do mais valor do trabalho.

Compreendemos que todos trabalhos - imaterial e material - são imbricados e interseccionados. Entre os jornalistas, por exemplo, há uma forte tendência que julga exercer apenas o trabalho intelectual, contudo esses profissionais sofrem por ficarem horas sentados em frente ao computador com dores na lombar e lesões por esforço repetitivo, sintomatizando no corpo a face material do trabalho.

O trabalho imaterial atende às necessidades do sistema de produção contemporâneo com "[...] atividades de pesquisa, comunicação, marketing para poder chegar ao produto que é vendido antes de sua fabricação". Ainda segundo Antunes, é o trabalho imaterial que "[...] ativa e organiza a relação produção-consumo." (2002, p. 126) Com a descentralização da produção, a tecnologia assumiu papel central na organização e gestão do trabalho em toda "cadeia de mercadorias" (HOPKINS; WALLERSTEIN, 1986) ou "cadeia de valor" (PORTER, 1985) ou até mesmo “cadeia de valor global”. (HUWS, 2008)

Isso não significa relativizar a predominância do tipo de trabalho e o seu papel como gerador de valor. Com o desenvolvimento das tecnologias, o trabalho imaterial articula produção e consumo, e cumpre papel fundamental no processo de valorização, “[...]reduzindo o tempo de circulação do capital e o tempo total de rotação [...]" (ANTUNES, 2018, p. 47).

A indústria ${ }^{79}$ da comunicação cumpre papel privilegiado para acelerar a circulação da produção que vai desde os softwares e sistemas de informação, a serviço da lógica do estágio atual do capital, à financeirização. Os monopólios da Google e do Facebook que concentram excessivamente o tráfego em toda rede mundial de computadores e assim acumulam informações de mais da metade da população mundial, até os monopólios nacionais e internacionais na área do jornalismo, encarregados do papel de servidores ativos para a classe dominante de seus países, são ligados pelo lastro financeiro com a elite internacional.

Outro fator torna ainda mais complexo o papel dos conglomerados de comunicação na cadeia econômica atual. Segundo Janaina Visibelli (2018, p. 186), os conglomerados de comunicação têm propriedades cruzadas na área com tipos variados de negócios que configuram o monopólio de comunicação e a articulação com os políticos, caracterizando o chamado por Lima (2010) de “coronelismo eletrônico". Ademais, as "famílias" detentoras

\footnotetext{
${ }^{79}$ Indústria do ponto de vista marxista, como organização dos setores econômicos e não como fábrica, setor fabril.
} 
desses meios "[...] participam de uma rede de empreendimentos distribuídos em diferentes setores produtivos e no processo de territorialização do capital, além da articulação com atores políticos têm laços com outros setores econômicos."

O processo de venda da editora Abril para um grupo financeiro e a sua migração para oferta de material didático e a reestruturação da Folha de S. Paulo que atua no mercado financeiro com o Pag Seguro do UOL são evidências da constituição financeira variada dentre os grupos de comunicação.

O objetivo do duopólio mundial da comunicação como dos grupos brasileiros é o mesmo: gerar valor. Não importa que seja através de um serviço bancário, com uma mercadoria ou com dados coletados para uso publicitário, mas sim gerar mais valor dentre a cadeia produtiva do capital.

Diante disso, há aproximação da comunicação com a indústria de transporte na teoria de Marx e Grundisse, que se singulariza “[...] por aparecer como continuação de um processo de produção dentro do processo de circulação e para o processo de circulação.” (2008, p. 168) Com base nessa análise, podemos situar o trabalho do profissional da comunicação com a imbricação necessária entre trabalho imaterial e material dentro da cadeia de geração de mais valia que somente é feita com a venda da força de trabalho.

Desde modo, a comunicação auxilia na redução do tempo de produção e circulação, aumenta a produtividade e diminui o tempo de rotação do capital em que se realiza o mais valor com o consumo da mercadoria produzida. Fica claro no livro dois de $\mathbf{O}$ capital, de Marx, que o sentido do capital é a sua valorização, portanto, a redução do tempo de circulação é um imperativo à acumulação. "Quanto mais as metamorfoses da circulação do capital são apenas ideias, isto é, quanto mais o tempo de curso é igual ou próximo a zero, tanto mais atua o capital e tanto maior se torna sua produtividade e autovalorização.” (MARX, 2017b, p. 204)

É dentro desse contexto matricial que está o trabalhador da comunicação. A ausência de um produto material não significa a ausência de um processo de produção, geração de lucro, mais-valia e o trabalho, que assume posição central para o movimento do capital em tempos de financeirização.

Não existe mais-valia sem a mercadoria da força de trabalho. De acordo com a teoria marxista, é a força de trabalho a única mercadoria “[...] cujo valor tem propriedade peculiar de ser uma fonte de valor.” (MARX, 2017, p. 203) O trabalho é essencial para geração de valor, 
por isso, como afirmamos acima, a estratégia atual do capital é invisibilizar o seu valor para gerar mais valor. (ANTUNES, 2018)

Da mesma forma, a não identificação da mercadoria ou a visão de um processo de produção da mercadoria apartado da extração da mais-valia do trabalho, aparenta dissolver a teoria do valor, como no processo de produção de dados do Google e do Facebook, por exemplo.

Portanto, há a busca de pesquisadores em posicionar e identificar as características do trabalho na nova divisão internacional do trabalho dentro da complexa cadeia de valor. É preciso refutar a concepção positivista da supremacia da tecnologia ou da elevação do trabalho imaterial como único tipo de trabalho. Ao mesmo tempo, sem negá-los e tampouco preservar a lógica das relações de trabalho sem assimilar as novas mudanças decorrentes do processo de reestruturação permanente do sistema capitalista. Ao exaltar a tecnologia como a ciência capaz de dirimir as contradições capital trabalho, acentuando “[...] o valor transformativo dos novos métodos de trabalho para a vida social, em especial, para a melhora das relações familiares e padrões mais igualitários entre os sexos [...]", Castells (2017, p. 334) vislumbrava um mundo em que o "trabalho normal" seria extinto, dando lugar ao trabalho flexível que traria também mais igualdade e menos contradições nas relações.

Os embates teóricos acerca da conceituação do trabalho presente em toda a cadeia da indústria cultural têm diferentes clivagens. Raymond Willians (1979), ao tratar os meios de comunicação como meios de produção, por estes serem suportes na origem de outras relações sociais, afirma o trabalho cultural como material e econômico em que a cultura é "[...] uma totalidade que liga todos os processos produtivos físicos." Nesse sentido, a cultura empregada aqui não significa cultura popular, mas também o aparelho de som, o teatro, a informação, comunicação que são mercadorias ao mesmo tempo que possuem dimensões culturais e sociais, portanto, o conceito de cultura deve ser estendido ao domínio da produção econômica e da criação de valor.

Para Fuchs e Sandoval (2015, p. 5), o “[...] trabalho cultural é uma unidade de trabalho cultural físico e trabalho informacional e a produção de significado, normas sociais, morais e comunicação de significados e valores morais são processos de trabalho que criam valores de uso," 
Do mesmo modo, David Hesmondhalgh (2013, p. 16) define o trabalho cultural como aquele que "cria símbolos" e tem como central o produto produzido. Já Vincent Mosco e Catherine McKercher ampliam as fronteiras do conceito e incluem em trabalho comunicativo "[...] qualquer um na cadeia de produção e distribuição de produtos cognitivos." $(2009,25)$ Dessa forma, para Hesmondhalgh, tanto os mineiros que produzem o minério que dá origem ao aparelho smartphone como o engenheiro que desenvolve o software que baixa o custo de produção estão fora da limitação conceitual de trabalho cultural. Entretanto para Mosco e McKercher, a amplitude do conceito coloca todos os trabalhadores do processo industrial dentro do conceito deixando abertas possibilidades para a união desses além das organizações do trabalho.

Huws (2017, p. 39) adentra em uma das clivagens do trabalho cultural e nomeia como trabalho virtual aquele "[...] pago ou não, que é realizado usando uma combinação de tecnologias digitais e de telecomunicações e / ou produz conteúdo para mídia digital.” A conceituação é próxima a de trabalho digital (FUCHS; SANDOVAL, 2015), que define esse tipo de trabalho como modo específico de trabalho cultural que “[...] contribuem para existência de tecnologias e conteúdos digitais.”

Outros tensionamentos fazem parte da conceituação de trabalho cultural e/ou digital, como a falta de liames entre trabalho e consumo, cocriação e a fusão entre trabalho remunerado e não remunerado no ambiente on-line como geradores de valor.

Dentre a nossa pesquisa, observamos que o trabalho, como criador de símbolos e sentidos, do jornalista é organizado de maneira virtual desde em chats de programas como GTalk, Telegram ou WhatsApp até em sedes físicas. Dos quatro arranjos, apenas um não tem redação virtual, embora o contato com os seus principais colaboradores seja por e-mail, também tendo em vista a facilidade de organização e diálogo.

\section{As redações virtuais}

Como podemos apreender, as relações nos arranjos alternativos pesquisados são marcadas pela precarização estrutural do trabalho e, como vimos, não é somente neste tipo de mídia, mas também nas grandes corporações de mídia essas relações se dão em maior ou menor grau, visto que é um fenômeno global. Nos dois tipos de redação temos a imposição de 
ter um jornalista polivalente, multitarefa, engajado e sem limites entre tempo de trabalho e não trabalho na execução do trabalho cultural e digital por criar valores de uso e de troca.

Ademais desses lugares e fenômenos, os arranjos alternativos se encontram também na crescente virtualização do trabalho do jornalista com a implantação das redações on-line como espaço social que tem o objetivo de organizar o trabalho jornalístico.

Há estudos que apontam a crescente convergência tecnológica das redações nas corporações de mídia que buscam integrar as unidades de produção ou de negócios para otimização de suas propriedades cruzadas. Jenkins (2008, p. 29) é um dos autores que mais aparece na explicação do conceito de "convergência" dos fluxos de conteúdo das diversas plataformas de mídia, mercados, público e audiência com base nas inovações "tecnológicas, mercadológicas e sociais".

É importante ressaltar que em nossa pesquisa, através do olhar sobre o trabalho e as rotinas produtivas, esses processos de transformações que alteram as relações sociais são derivados do avanço das forças produtivas e da própria reestruturação do sistema capitalista. Como já afirmamos em outros momentos do texto, essa recomposição é permanente e inerente para sustentação da cadeia de valor global do capital.

Não é somente no jornalismo que esse fenômeno acontece. Contudo, pelo papel da comunicação como qualificadora e exponente da geração de valor e por seu papel como servidor ativo do sistema dominante, podemos verificar nas relações de trabalho do jornalismo como "antessala" das mudanças de determinadas relações sociais.

Assim como em outros momentos de crise do capital, a de 2007/08 trouxe para o centro a virtualização do trabalho e as plataformas como novo modo de organização do trabalho. Basta perceber a fundação de plataformas como Airbnb e Taskrabbit, fundadas em 2008 como forma de acesso ao trabalho do que Marx chamou de superpopulação relativa ou contingente flutuante (Capital I, capítulo 23).

As mudanças consolidadas com o avanço das forças produtivas, desenvolvimento das tecnologias de informação e comunicação combinadas com o acesso aos softwares, programas e aparelhos por meio da conectividade, configuram-se como espaços de reorganização do trabalho.

Ursula Huws (2017, p. 30) aponta que, embora tenha se tornado estrutural após a última grande crise do capital, esse fenômeno está “[...] longe de ser novo e representa uma 
convergência entre várias tendências diferentes ao longo de várias décadas." A autora cita exemplos como a Elance, fundada em 1999, a Odesk ${ }^{80}$, de 2003 que se fundiram em 2015, criando a Upwork, e a Amazon Mechanical Turk ${ }^{81}$, fundada em 2005.

Tom Slee, no livro $\mathbf{O}$ que é seu é meu: contra a economia do compartilhamento, mostra que a chamada sharing economy (BENKLER, 2004) evidencia a nova onda da precarização através da exploração do trabalho de plataforma, cujos direitos e garantias sociais são a base da acumulação de capital dos investidores e arquitetos proprietários desses espaços de trabalho por meio da propagação do ideal livre e desregulado mercado.

Também conhecida como "economia dos bicos" (gig economy), "consumo colaborativo" (BOTSMAN; ROGERS, 2010), cloudsourcing (VAQUERO et al., 2008; MUHIC;JOHANSSON2014), crowdsourcing (HOWE;ROBINSON, 2005; ESTELLÉSAROLAS; GONZÁLEZ-LADRÓN-DE-GUEVARA, 2012) ou a nuvem humana (KAGANER et al., 2012), a economia do compartilhamento prega a troca de tempo ou propriedade por remuneração através da relação mediada por um software que faz toda transação financeira, estabelece o seu próprio e unilateral método de avaliação do trabalho e pode encerrar a relação de trabalho quando quiser, não precisando estabelecer qualquer compromisso com o prestador de serviço. Na propaganda do serviço da Uber o principal atributo é o trabalho flexível que oferece ao motorista o controle de seu horário, mesmo ele tendo que trabalhar mais de dez horas por dia para conseguir mínima remuneração.

Embora nosso foco não seja a plataformização com a mediação de software, como as citadas acima, há traços comuns no processo de virtualização do trabalho do jornalista que, como vimos no caso dos jornalistas da Agência Pressenza, acabam fazendo parte de uma cadeia de valor complexa que conta com a proliferação de intermediários e terceirizados.

Na Agência Pressenza, a redação virtual conecta ativistas humanistas espalhados em diferentes países para alinhamento da pauta, divisão de responsabilidades e discussões cujos temas exigem postura editorial do arranjo.

É discutido em nível internacional, mas é lógico que cada redação vai tendo suas características locais, até por terem contextos muito diferentes, enquanto lá na Europa, a redação está discutindo muito a renda básica universal, porque é o grande tema hoje, aqui na América Latina, isso nem é assunto quase. (...) Então, depende

\footnotetext{
${ }^{80}$ Elance e Odesk eram duas plataformas de freelancers que conectam empresas e profissionais independentes que se juntaram e fundaram a Upwork com o mesmo objetivo.

${ }^{81}$ Plataforma criada pela Amazon para contratação de pequenas tarefas e soluções que os computadores não conseguem realizar.
} 
muito dos contextos e acaba ganhando mais ênfase ou uma ou outra pauta. É natural, por exemplo, dentro do Brasil, a gente tem duas redações, São Paulo e Rio. Agora, o Rio está mais fraco, mas tem uma galera...Só de São Paulo para o Rio, estão próximos, mas, às vezes, a pauta muda muito, porque lá há uma série de conflitos. (Guilherme de Almeida, 2018)

Como podemos observar, a redação virtual agrega profissionais de distintos países e estados - como é o caso do Brasil, contudo também é o espaço de conflitos, tensionamentos acerca do jornalismo e onde se expressam as múltiplas dimensões do trabalho, como o jornalista entende a sociedade e os valores acionados para o trabalho como para si próprio.

Dentro da redação virtual dos Jornalistas Livres, o método de trabalho para publicação de qualquer material jornalístico é ser aprovado por três pessoas que precisam estar presentes no chat na hora da discussão da pauta. Isso acarreta certo tensionamento constante do jornalismo expressos nas perguntas sobre o que é pauta, se está de acordo com a linha editorial do veículo, o que merece ser publicado, com qual viés, linguagem e enfoque sejam questões permanentes para todos os membros do coletivo.

Essa tensão constante por um lado evidencia as dissensões entre o grupo e por outro torna o jornalismo do coletivo pungente e com vigor, diminuindo as possibilidades de erros por contar com vigilância coletiva.

Sugiro a gente assistir os programas de humor e sensacionalistas, não pra copiar, mas pra entender o que o povo vê, do que o povo ri, como o povo se informa e do que ele gosta. Lembrando sempre e pra sempre que nós também somos o povo, sentimos raiva, damos risada de um monte de besteira, somos ignorantes em quase tudo, ou seja, a linguagem e os temas da nossa turma tbém interessam e nunca vamos deixar de fazer o que já estamos fazendo, na linguagem que estamos fazendo. O que estou propondo é que a gente abra o leque. (Maria Filomena, 2018 ${ }^{82}$ )

A redação do Jornalistas Livres funciona em regime $24 \times 7$ ( 24 horas por sete dias da semana), como são chats as pessoas podem entrar, verificar o debate que está acontecendo, se quiser se posicionar ou não, assumir um trabalho ou não e sair.

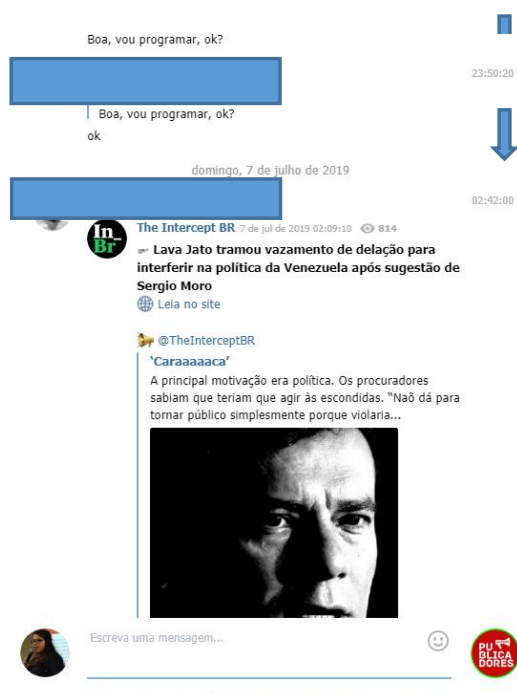


Os desafios de trabalhar na redação virtual vão além dos tensionamentos do jornalismo. Como em qualquer outro lugar, o dispositivo comunicacional (MAINGUENEAU, 2001) organiza o discurso orientado pelo locutor, com uma finalidade e forma de ação em uma interatividade e dialogismo.

O chat é tudo, é onde a partir dele você estabelece as relações. No começo a gente tinha muita treta nos chats, mas é porque a comunicação pelos chats ela não é oral, nem verbal. Ela é um mix. Então, a pessoa fala uma merda que é mal interpretada e aquilo vira mó melê, de repente começa todo mundo a se xingar. Se fosse olho no olho a pessoa não falava aquilo, ela talvez seria mais comedida, se ela estivesse escrevendo um texto, talvez seria de outra forma. Então existem filtros entre a comunicação escrita e verbal que ali é outra comunicação. A gente já passou por tantas discussões, brigas, bate à porta do chat que é quando a pessoa sai correndo do chat, temos tantas histórias que fomos aprendendo a mediar isso de uma nova maneira. (Ana Cláudia da Silva, 2018)

A confusão relatada pela jornalista demonstra as condições de produção do discurso, a situação de fala, o local através do chat que marcam o valor e o posicionamento político daqueles que interagem no grupo e estabelecem uma compreensão mediada por meio do dispositivo. Como a jornalista relata, se fosse em outro a mediação seria diferente.

Já no Opera Mundi, a estrutura de trabalho tem semelhanças ao da redação tradicional e a redação é mista. O grupo já esteve presente no WhatsApp, mas devido à falta de noção de tempo de trabalho e não trabalho emanada pelo uso da rede social fechada ${ }^{83}$ decidiu migrar para o G-Talk ${ }^{84}$. Ademais essa mudança, quando houve o debate para que se tornasse apenas uma redação virtual, os próprios jornalistas se colocaram contrários à decisão e convenceram os proprietários a ter um espaço físico com a indicação do reflexo na qualidade do jornalismo produzido e, consequentemente, ao alcance do público.

A discussão sobre o espaço social de trabalho somente foi possível mediante a presença e encaminhamento coletivo da questão após discussão presencial entre os trabalhadores da notícia. No caso do teletrabalho, a pressão coletiva é praticamente impossível, visto que o trabalhador fica afastado dos seus pares, não consegue identificar o que o unifica com o conjunto de sua categoria, exercer solidariedade ou se organizar.

\footnotetext{
${ }^{83}$ WhatsApp, Telegram e Signal são considerados sites de redes sociais fechados por ter outra lógica diferente do painel de atualizações de perfil.

${ }^{84}$ Aplicativo de conversa da Google.
} 
Hoje, após as mudanças indicadas pelos jornalistas, a redação é mista, sendo que o espaço virtual de trabalho tem a função de controlar a produção geral. A cada postagem no site, o jornalista coloca o link na redação virtual para checagem do superior e ordenamento do que é produzido. Os espaços de trabalho são sempre espaços de normatização, renormatização, criação e controle. Nesse caso específico fica claro como a própria redação e a tecnologia são também o instrumento de monitoramento e controle do trabalho.

A redação virtual do Opera Mundi também tem como objetivo agrupar os jornalistas da sede física com os que ficam fora dela. A produção do quadro 20 minutos é toda feita no ambiente digital em um grupo do WhatsApp.

Somente foi possível alcançar algumas características da redação virtual por termos seguido o caminho etnográfico na pesquisa.

Após a observação participante, podemos inferir que a redação virtual é o espaço social de produção do jornalismo, que junto com as ruas onde é realizada apuração in loco das matérias, é o "chão de fábrica" para jornalistas da mídia alternativa cujo objetivo é organizar, estabelecer a rotina produtiva, consolidar métodos de produção do material jornalístico, se relacionar com as fontes que ora também assume o lugar de público receptor da comunicação produzida nesse espaço. A redação virtual substitui o deslocamento, é o espaço para montar equipes virtuais, independentemente do local, com requisitos específicos em projetos determinados, criando oportunidades de participação de jornalistas.

É o ambiente em que se modulam e se padronizam as relações de trabalho e é o local possível para se observar como esses jornalistas falam sobre e no trabalho em termos ideológicos; como constroem valor de uso e de troca; e como se dão as novas formas culturais das relações de produção, bem como os valores mobilizados para o trabalho e o que levam do trabalho para a sociedade.

A redação virtual é um espaço finito, delimitado e exequível para acompanhar e analisar as transformações do jornalismo, das condições de trabalho do jornalista e as mudanças quanto aos meios de produção, assim ver como os profissionais interagem nesse contexto determinado com as tecnologias de informação e comunicação. 
Pode ser considerada uma redação virtual o agrupamento on-line a partir de três ou mais jornalistas, configurando um arranjo que atua para produzir material jornalístico. A redação pode ser dividida por função ou linguagem (secretaria de redação, editor, fotógrafo, texto, vídeo, charge, tradução, designer etc.), ou editoria (nacional, internacional, política, moradia, cidades, direitos humanos etc.), coberturas, programas ou projetos especiais (em torno de eventos, acontecimentos, elaboração de livros, manuais, reportagens e programas especiais) ou por interesse dos colaboradores (educadores, trabalhadores do transporte, petroleiros etc.) que ora são fontes, ora cumprem papel de elaborar a matéria ou parte dela.

Assim como na redação física, o espaço social da produção jornalística também é marcado por hierarquias e atribuições diferenciadas. Nos veículos que analisamos, as relações são mais horizontais e o profissional goza de mais liberdade e autonomia no fazer jornalístico. Entretanto, essas relações estão localizadas em espaços diferentes, como podemos verificar na imagem do fluxo de trabalho do Jornalistas Livres.

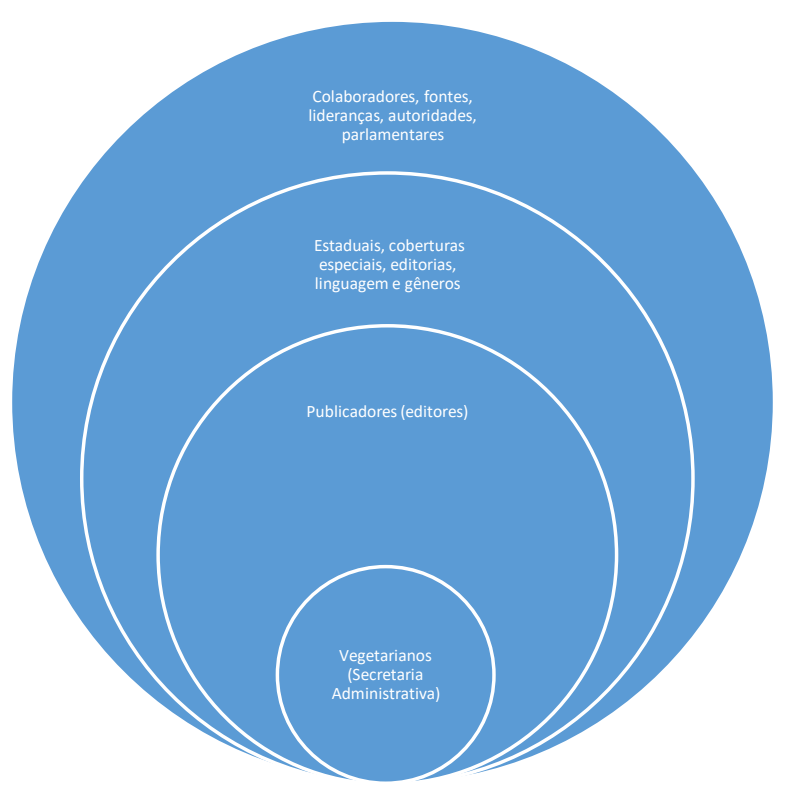

Essa figura ilustra a hierarquia no Jornalistas Livres, cujas posições centrais orientam e decidem a produção jornalística. Embora essa organização seja diferente da verticalização da redação física, os círculos denotam a presença de direção no arranjo. O círculo menor é o núcleo dirigente que conta com menos pessoas e decide quem entra nos grupos, questões práticas etc.

O segundo círculo, a redação de Publicadores, engloba a secretaria e decide sobre as postagens, conteúdos, distribuição de pauta etc. Os espaços destinados a coberturas estaduais, 
especiais e linguagem decidem sobre temas específicos atribuídos para esses locais; e o Colaboradores é um espaço amplo para encaminhamentos de textos prontos, fotos, sugestões de pautas etc. Cada círculo representa um esfera de decisão.

Da mesma forma, no grupo do G-Talk, do Opera Mundi, quando o editor-geral ou o coordenador da redação indica um ajuste que deve ser feito em alguma matéria, mesmo estando em espaço virtual do trabalho em que todos os presentes podem fazer esse tipo de apontamento para correção da matéria só quem faz são aqueles legitimados para fazer a indicação e organizar o trabalho, ou seja, os “chefes". É importante ressaltar que cada coletivo ou veículo tem a sua organização em dada e concreta situação, sendo a natureza e objetivo definidores das rotinas produtivas dos arranjos.

As redações virtuais analisadas estão inseridas em aplicativos e softwares com origem no exterior (Estados Unidos e Rússia). Essas plataformas detêm e produzem discursos ideológicos próprios e aparentam modificar as relações de produção, ser espontâneas, sem hierarquia, livres e sem interesses no controle algorítmico e na concentração de tráfego na rede mundial de computadores. Aparentam ser componentes da esfera pública, quando são essencialmente privadas. Os coletivos e veículos alternativos que analisamos dependem desses aplicativos e softwares para existirem como lugar social do trabalho

Outro fator que podemos compreender é que a redação virtual representa o espaço de transformações na produção do jornalismo, contudo, dialeticamente é o espaço em que se dão as contradições do trabalho e as relações mais precárias, em alguns casos, similares com as do século passado, sem jornada fixa, divisão de tempo de trabalho e não trabalho e intensidade do trabalho com engajamento total e polivalência. Quanto menos formas de sustentação, maior a dependência da tecnologia para fazer jornalismo.

Após analisar o contexto organizativo concreto e o papel das tecnologias de informação e comunicação, vamos apontar agora transformações em atribuições e nas teorias do jornalismo.

\section{Renovações das práticas jornalísticas}

O processo no qual está inserida a nova configuração da rotina produtiva e a instituição das redações virtuais da mídia alternativa dialoga com diferentes interfaces tais 
como o aprofundamento do modo de acumulação flexível, o cenário pós-crise de 2007, a concentração de grandes e mundiais monopólios, a migração dos recursos publicitários para internet e compra de dados conforme nova lógica da publicidade, o papel do jornalismo na sociedade contemporânea e no aperfeiçoamento da democracia em meio à disputa pela nova ordem mundial, despontada por dois polos na disputa por tecnologia: Estados Unidos e China.

Nesse contexto, ter como centro redações descentralizadas que apresentam aspectos articulados com o modo de produção toyotista é revelador das formas e contradições entre capital e trabalho. Essas contradições se apresentam como tensionamentos dentro do próprio jornalismo, cujas novas marcas ainda não se consolidaram e os velhos modos de trabalho ainda não foram superados; aspectos comuns de momentos de transição, crise e realidades instáveis em que há um embate entre o inovador e o anacrônico dentro do processo de produção do jornalismo que nunca é pronto e acabado, ao contrário, está sempre se transformando.

Os arranjos alternativos analisados nessa pesquisa nasceram em formato digital e são frutos do acesso aos softwares, programas e à internet. Portanto, a convergência em unidades de produção que é habitual em pesquisas sobre a redação das grandes corporações de mídia, não se aplica.

É importante notar a pluralidade de veículos de mídia alternativa, suas naturezas, objetivos e a segmentação de seu público e quanto isso faz com que os formatos desse tipo de mídia sejam acumulativos. Sem dúvidas, há coletivos que utilizam ainda hoje o fanzine, como a Casa da Lapa de São Paulo, a rádio Cipó, em Belém do Pará, e outras formas de estabelecer a comunicação com o seu público.

Como vimos, na história da mídia alternativa brasileira ter os meios de produção e, consequentemente, liberdade de impressão e expressão sempre foram desafios à vitalidade duradoura desses veículos. Dispor de condições de ter jornalistas dedicados ao trabalho, garantir a periodicidade e a sustentação dos veículos são adversidades que atravessam toda a história das experiências da comunicação alternativa.

Contudo, para a maioria dos veículos e coletivos de mídia alternativa, o principal obstáculo não é mais com quais meios fazer, como era antigamente, visto que o celular é um dos primeiros meios de transmissão de vídeo ao vivo, de edição do texto, para fotografar e 
publicar nos sites e redes. A dificuldade atual é a distribuição, circulação e ampliação do alcance do sentido do material produzido. Essa problemática também ocorria em outros momentos, antes do desenvolvimento objetivo dos meios para produção, mas se não havia condições de impressão a circulação do discurso já estava comprometida.

Desse modo, o avanço e acesso aos meios diminuiu a lacuna entre a produção da redação tradicional e da mídia alternativa, distanciando do rótulo de amadora, que a grande imprensa sempre colocou nos meios alternativos.

Nesse mesmo processo, a internet, que chegou a "ludibriar" muitos pesquisadores sobre o novo e potencial espaço da esfera pública com difícil controle e restrição por parte dos conglomerados de comunicação e dos limitadores da liberdade de expressão, como se fosse um espaço à parte, evidencia hoje a sua lógica danosa às democracias ao redor do mundo com a concentração algorítmica e o uso dos dados da concentração de tráfego na disputa política em diversos lugares do mundo, como ficou explícita a atuação de Steve Banon com seu projeto populista de direita e neoliberal.

Ademais, os discursos dos monopólios da comunicação são reforçados através da internet, configurando-se como extenso lastro nas redes sociais. A força econômica dos monopólios de comunicação transborda para esses espaços reforçando a sua hegemonia e fortalecendo seu bloco histórico. (GRAMSCI, 2002)

A outra faceta da internet pode ser considerada uma fissura do sistema que possibilita a constituição de um circuito independente de trabalho, conecta ações comuns, como analisado nas redações virtuais dos veículos analisados, a troca de experiências, constituição de redes, amplia as formas de cooperação e potencializa a circulação da informação dos meios alternativos.

Essa nova forma de organizar as rotinas produtivas e sua rede de jornalistas colaboradores tensionam o jornalismo feito pelas corporações de mídia de diversos modos. Um deles é de diferenciar e negar o sentido jornalístico da mídia alternativa, colocando-o como jornalismo "panfletário" ou "engajado" (Manual da Folha e Diretrizes do Grupo O Globo, ambos de 2018).

Em que pese haver poucos estudos sobre as rotinas produtivas e as condições de trabalho dos jornalistas da mídia alternativa, podemos inferir, após longa observação, 
mudanças na forma de produção da notícia e, consequentemente, certa atualização na teoria do newsmaking. Essa mudança é provocada pelo uso das tecnologias da informação e comunicação que passa a ser a face principal da mediação do trabalho.

A partir do ponto de vista da sociologia do conhecimento e da sociologia das profissões, a abordagem teórica do newsmaking combina a cultura profissional dos jornalistas, a organização do trabalho e os processos produtivos (TUCHMAN, 1978), enquadrados por valores-notícia, critérios de noticiabilidade, formato e a construção da audiência (WOLF, 2012).

Longe de a rotina ser um desencadeamento de movimentos mecânicos e predeterminados, faz parte do andamento produtivo tensões articuladas com o sentido ético da profissão, os valores que são necessários negociar no desenvolvimento de suas atribuições, a concepção de mundo do profissional e a posição editorial do veículo que dialoga com sua natureza e objetivo.

Do ponto de vista ergológico, o trabalho é sempre inédito (SCHWARTZ, 2008) e mesmo sua prescrição passa por um percurso de renormalização em que a própria norma é corrigida, tensionada e seus fundamentos entram em novas relações. Contar com uma rede ampla de jornalistas, em que muitas vezes a falta de condições, e o trabalho não alienado goza de mais liberdade e autonomia, faz esses embates e as "dramáticas do uso de si" (op. cit.) serem frequentes e marcarem o sentido do jornalismo produzido

\begin{abstract}
A imprensa pungente está na internet. O que eu acho que os JLs têm de original a tudo o que tem aí. A experiência do JL foi muito inspirada naquilo que os Ninjas eram em 2013, porque todo mundo se dizia Ninja. Não é só que os Ninjas estavam ancorados nas redes sociais como plataforma, eles se organizavam também como rede. Era uma rede de colaboradores. Diferente dos blogueiros que não são rede, eles usam as redes sociais, mas se comportam ainda como se fosse um artigo para uma revista ou jornal. (Mônica Galvão, 2018)
\end{abstract}

A construção das etapas de produção na redação virtual é feita em rede desde a apuração, edição e construção da pauta. Muitas vezes isso ocorre não somente entre os jornalistas do veículo, mas entre outros sites e coletivos da mídia alternativa. Essa é uma diferença essencial entre as redações tradicionais e a da mídia alternativa. $\mathrm{Na}$ mídia tradicional, muitas vezes, em busca de um reconhecimento e para se manter no trabalho, o jornalista encara o colega ao lado como seu opositor. A disputa por furos entre as empresas de comunicação é ainda mais sem ética na busca da matéria exclusiva. 
No espaço virtual de trabalho dos arranjos alternativos, o editor-geral não dirige as matérias, mas contribui com as etapas da construção jornalística e, ao mesmo tempo, cria modelos de gestão. Mônica Galvão, por exemplo, relatou em entrevista que faz gestão, reportagem, pauta e edição premida pela falta de recursos humanos para dividir as atribuições. "Porque os JLs têm uma coisa que é assim: fui entrevistar a Marcia Tiburi, senão tiver ninguém para editar, quem vai editar sou eu, entendeu. Então, você é um praticamente faz tudo.” (Mônica Galvão, 2018)

Na Agência Pressenza, Guilherme de Almeida também realiza diferentes funções. Organiza a pauta da semana, distribui as pautas, coordena a produção e contribui com a formação dos profissionais em temas que tem expertise como otimização de site, análise e mineração de dados.

No caso do Opera Mundi, a referência de trabalho é próxima da redação de uma corporação de mídia e o editor-geral é responsável por pautar os outros jornalistas e:

[...] ficar de olho no noticiário, olhar o que o site vai dar ou não. Essa decisão acaba sendo minha no final. [... [Então, eu cuido de pauta, texto, questões administrativas como decisão de folgas, plantão e nesse momento eu tenho ajudado na manutenção porque a gente não tem um secretário. (Paulo Correia, 2018)

Desse modo, o papel do editor-geral ou o coordenador de redação passa por uma atualização, seja pelo entendimento de suas funções ou por questões de falta de estrutura. No relatório sobre a adaptação do jornalismo "aos novos tempos" elaborado por Anderson, Bell e Shirk (2013, p. 53), a função do editor é “[...] agregar conteúdo, dar links para material produzido ou não pela organização, fazendo uma meta-análise do processo e de fontes, dando continuidade à cobertura com o cultivo e a recomendação de fontes em público." Como observamos, na redação virtual o editor faz muito mais que essas atribuições.

Novas funções emanam do trabalho digital. O grupo destinado aos editores do Jornalistas Livres é chamado de Publicadores, sendo que "[...] todos que estão nesse chat cumprem também a função de editor." Porém, o publicador é mais do que editor, porque muitas vezes a função não é editar algum material e sim só postar numa rede social ou no site. O trabalho está longe de ser mecânico ou copiar e colar, visto que cada plataforma terá o material distribuído com as características que já são enquadradas por elas. Por exemplo, no Twitter, o publicador precisa elaborar a matéria com até 280 caracteres, utilizar a mensagem mais apropriada para esse mídium que é diferente da postagem feita no Instagram ou Facebook. 
As diferenças exigidas são marcadas até pelo léxico utilizado pelos jornalistas. "Telegramar" (enviar mensagem no Telegram), "facebookar" (postar mensagens no Facebook) e "instagramar" (fazer postagem no Instagram) são sinônimos de ações específicas do trabalho jornalístico. Da mesma forma que "fazer base" significa ficar de plantão e ser o responsável pela curadoria de conteúdo, distribuição e circulação do material produzido e enviados por colaboradores em diferentes lugares.

Durante um dia de cobertura intensa esse trabalho requer um método apropriado para que o conteúdo chegue ao seu destino. Fazer base significa organizar o fluxo, estabelecer critérios de relevância do conteúdo, encaminhar para os publicadores que autorizam a publicação, garantir a publicação, gerar o link e distribuir em diferentes grupos para assegurar a circulação. Ana Cláudia (2018) cumpre o papel de mediação entre os grupos e relata que administrar todos os chats, passar informação de um para outro, de maneira frenética faz com que se sinta "[...] muitas vezes como aquelas telefonistas de antigamente tirando um cabo e conectando o outro ou como um chefe de reportagem no tempo que ele organizava o local."

A fluência do trabalho em rede é valorizada na redação virtual, mas o desafio de controlar quem pode publicar e em qual rede para manter a vigilância e qualidade do material exige novas atribuições.

Cláudia Abraão (2018) afirma que além das suas atribuições de gravar e editar vídeos, fazer textos e base e distribuir o conteúdo, também é uma mediadora de conflitos e guardiã de todas as senhas que dão acesso aos canais de distribuição.

Essa mediação de conflitos explicitada por Abraão é mais exigida, por óbvio, nas redes maiores e, consequentemente, mais complexas, cuja relação é de trabalho voluntário ou nos espaços onde as relações de trabalho são mais precárias. Isso se dá porque a maioria dos jornalistas não atuou em cargos de chefia de grande jornal para acumular bens, não pertence à família rica ou tem outra forma de sustentação financeira a não ser vender a sua força de trabalho. A grande parte do quadro profissional da mídia alternativa é feminino e jovem, o que corrobora com as pesquisas sobre o perfil do jornalista (FÍGARO; NONATO; GROHMANN, 2013).

A busca das jornalistas é trabalhar e se sustentar através do jornalismo, por isso lideram projetos os quais podem se desenvolver, construir um portfólio e, quando é bemsucedido, viver desse trabalho. Até essa meta ser alcançada o percurso que precisam percorrer é longo, sendo esse um dos principais motivos que desequilibra a relação, diminui a frequência e ininterrupção da atuação no projeto. 
Essa situação fica clara no discurso de Ana Cláudia (2018) ao demonstrar essa dificuldade: "[...] o comprometimento da mais-valia é um e o comprometimento da sua valia, qual é? Quando entra um trabalho eu falo: agora entrou um trampo, tchau. Se eu volto é porque eu quero, se estou ali é porque quero."

No lugar do salário, a mediação é feita através de capital simbólico, reconhecimento por ter agregado ao seu nome o de um projeto, site ou coletivo jornalístico. Os contribuintes do Outras Palavras que escrevem artigos ou repassam seus trabalhos científicos para publicação passam a ter em seu "currículo" essa colaboração, passam a ser referenciados por esse papel ao mesmo tempo em que suas ideias e elaboração são propagadas pelo coletivo, alcançando mais gente. Isso fica claro no exemplo dado por Mônica Galvão (2018):

\footnotetext{
Por exemplo, o Anastasia trabalha no Gabinete X e quando ele está numa atividade ele entra no grupo e fala da atividade. Se tem a ver, vira uma coisa legal. O Deputado X tem um baita canal, mas os JL's atingem mais gente que eles não atingem. Então, vira um capital para o cara em que ele é ele mais uma rede que a gente disponibiliza para ele, dentro de um critério, claro.
}

Dessa forma, podemos verificar que não há venda de força de trabalho mediada por salário, porém há outros interesses e conflitos que são administrados pelo sujeito em atividade, revelando negociações que se dão a todo momento nas chamadas "dramáticas do uso si" (FÍGARO, 2008; SCHWARTZ, 2000b), em que uso de si por si mesmo e pelo outro atuam na execução, decisão e conjunto de valores acionados no trabalho.

Esse processo também mostra, com base na ergologia, que além da norma prescrita há a renormalização em que a experiência concreta sistematiza e reformula os saberes aplicados na situação de trabalho.

$\mathrm{Na}$ atribuição de "guardião de senhas", o controle e vigilância são rigorosos e há um método específico. Quando há mais de 58 publicadores (número de membros da redação virtual Publicadores), ela muda a senha e vai repassando para quem solicita e está dentro dos critérios estabelecidos pelo grupo. Outra atribuição sua é estabelecer contato com os profissionais dos sites sociais quando há algum problema técnico ou de cerceamento de liberdade de expressão, posto que as medidas em caso de punição ou retirada de conteúdo do perfil são unilaterais por parte da empresa de plataforma. Isso reforça o caráter privado e revela a postura ideológica que pode ser encarada como medida empresarial.

A atividade de gerenciador do programa de contribuição do Outras Palavras também é uma nova competência. Como vimos no Capítulo III, o site tem mais de dez anos e consegue se sustentar com o financiamento dos leitores. João Felício (2018) relata que o objetivo é 
conseguir doações de pessoas que acreditam na necessidade de que um portal com as características do Outras Palavras, que se posiciona e faz a crítica ao sistema capitalista, tem que existir e, em contrapartida, oferece descontos em serviços e produtos. A diferença aqui é a proximidade do gerenciador com o leitor que muitas vezes é também o colaborador do site.

A gente evita o termo assinatura, porque nosso conteúdo é aberto. Então, o cara não
está pagando para ter acesso ao conteúdo, o cara está pagando porque ele acredita na
necessidade do projeto e como contrapartida desse apoio que ele dá para o projeto, a
gente cria uma rede de vantagens para ele em restaurante, desconto em livros,
entrada de cinema, sorteios semanais, baladas, produtos orgânicos, e aí a gente tenta
fazer essa rede ser nacional [...] (João Felício, 2018)

O gerenciador de relacionamento tem liberdade para explorar e aumentar a rede com uma política que vai além do financiamento do jornalismo com recursos humanos, mas visa cativar o colaborar para contribuir com textos para o site.

$\mathrm{Na}$ redação virtual, o profissional tem liberdade de ação de maneira distinta da organização de trabalho de uma redação tradicional. O fluxo - e muitas vezes a ausência de um caminho para o processo produtivo - não se dá de forma “[...] militaresca em que é difícil fazer qualquer coisa sem pisar no calo de alguém [...]", como apontado por Anderson, Bell e Shirk (2013, p. 62) ao analisarem a redação tradicional.

De acordo com Franciscato (2018, p. 6), “[...] o fenômeno da inovação é, então, um elemento com potencial para pensar as transformações da atividade jornalística, das organizações e da profissão em um cenário de intensificação dos impactos das tecnologias digitais."

Em meio a essas transformações e às novas formas de sistematização e tratamento da informação, os critérios definidores de noticiabilidade e valores-notícias se encontram em transição. Esses critérios são comumente encarados de formas subjetivas, exterior à práxis jornalística, e colocam o profissional distante do acontecimento cujo papel é "apenas" relatar o fato.

De forma objetiva, a notícia ou produto informativo é resultado das negociações que acontecem em graus e motivações diferenciadas no seio do processo de produção desde a seleção até a publicação. O objetivo é atrair os leitores, chamando atenção para aspectos da realidade social que o veículo ou o coletivo seleciona.

Os valores-notícia não são estáticos e cumprem a função de nortear a produção cotidiana da matéria jornalística e suas ênfases, embora os interesses e a linha editorial sejam 
mais perenes e representem elementos de continuidade na decisão sobre porque o acontecimento é considerado notícia.

A própria organização da redação virtual por temas, a seleção de fontes e a linguagem utilizada indicam os critérios de noticiabilidade do arranjo alternativo.

Opostamente ao uso da fragmentação como tática de manipulação (ABRAMO, 2002), o recorte do acontecimento-notícia acontece para recomposição e explicitação do que é o fato, como, onde e quem o realizou e qual é o interesse em demonstrar o evento-notícia.

Wolf (2012, p. 207) afirma que os valores-notícias são resultados implícitos ou explícitos relativos "[...] aos caracteres substantivos das notícias; seu conteúdo; a disponibilidade do material e os critérios relativos ao produto informativo; o público e a concorrência."

No que tange aos critérios substantivos, o autor aponta a articulação entre a importância e o interesse da notícia com os envolvidos da matéria e sua posição hierárquica. Ao citar Galtung-Ruge, que defende que "[...] quanto mais o acontecimento interessar às pessoas de elite, maior será sua probabilidade de se tornar notícia [...]”, o sociólogo italiano evidencia que está olhando apenas para a redação das corporações de mídia e corrobora com a nossa sustentação teórica do papel que esses aparatos ideológicos (GRAMSCI, 2002) cumprem para os setores dominantes. Opostamente, o que podemos inferir é que quanto mais importa para a classe trabalhadora, mais terá chance de ser veiculada a matéria nos arranjos alternativos de comunicação. O forte viés institucional também é encontrado nesses meios, contudo as instituições fazem parte do movimento social ou de representação de segmentos.

A quantidade de pessoas que o acontecimento impacta ou envolve potencialmente; o interesse nacional ou o significado futuro para o desenlace de determinada situação são apontados como critérios que delineiam o conteúdo do produto informativo.

Sobre a disponibilidade do acesso às informações e à fonte para elaborar a matéria jornalística, a tecnologia é um fator de facilitação para transpor algumas barreiras geográficas e estruturais. Hoje, através da internet, a mídia alternativa consegue acompanhar e tratar informações sobre eventos que acontecem do outro lado do mundo. Porém, entre os critérios relativos ao material da comunicação se encontra um que tem mudado de qualidade: a periodicidade. 
Elliot (apud WOLF, loc. cit.) relaciona os valores novidade e frequência como contexto norteador da notícia. "A periodicidade da produção de informação constitui, por si só, o quadro de referência em que são percebidos os acontecimentos do mundo."

Ao referenciar a atividade jornalística como análise e relato de uma jornada ou período, a produção da notícia acontece dentro do ínterim da veiculação. No jornalismo realizado no ambiente digital, a lógica e noção de tempo são outras, desde o incontável tempo do imediatismo do furo até a periodicidade e tempo diferentes de acordo com a plataforma utilizada na distribuição. A mesma matéria produzida pelo arranjo é veiculada em diferentes dias e horários nos canais diversos de distribuição. O uso da tecnologia determina a versão e o horário de distribuição da informação, extrapolando a matéria jornalística.

O dispositivo comunicacional é o conjunto do circuito e das circunstâncias da fala que organiza o discurso produzido. Desde modo, o mídium modela o texto e as linguagens utilizadas, condicionando a recepção dos efeitos e sentidos (MAINGUENEAU, 2001) em que cada gênero tem a sua orientação quanto espaço e tempo. (VOLOCHINOV/BAKHTIN, 2014)

Do mesmo modo, não está clara qual a lógica da periodicidade de cada veículo. O tempo é diferente de publicação, como podemos ver nas tabelas que apresentam as datas da publicação, do período de coleta, são totalmente diferentes. O fato é que quando há o compromisso com a periodicidade e frequência, a rotina de produção é norteada por esse tempo de trabalho nas redações virtuais. É claro que esse critério sobre o produto está relacionado com a estrutura do arranjo de comunicação.

Chama atenção o critério denominado de "equilíbrio e balanceamento" por Wolf (2012, p. 219), estabelecendo que a “[...] cobertura de partido $X$ deve ser igual ao espaço dado ao partido Y [...]” como forma pluralista da notícia. A natureza dos veículos de comunicação alternativa, assim como os meios corporativos, é de se posicionar e ser parcial, sendo que esse equilíbrio, visto muitas vezes como "qualidade técnica", não existe na realidade do processo produtivo da informação.

Tudo é realidade, mas pode tirar foto a partir daqui, de uma câmera colocada aqui, a partir de lá, a estação é a mesma, mas você só enxerga a realidade a partir de um ponto de vista. Isso aí que eu acho que é o que alguns chamam de parcialidade. Parcialidade, para mim, não é você defender o seu partido, a sua parte, mas é você enxergar a realidade a partir de um lugar. Eu acho que sem isso é o caos. (Luiz Graciliano, 2019)

Quanto aos critérios relativos ao meio, o ambiente digital proporciona mais liberdade já que o tamanho da matéria não é limitado pelo espaço físico, no caso do jornal impresso, e nem pelo tempo como é na matéria televisiva. 
O uso do lead tem outra função do jornal impresso. O papel do início do texto é fazer com que o leitor seja envolvido para continuar a leitura em meio a tantos hiperlinks e camadas de textos que podem desfocar o leitor com apenas um clique.

As tecnologias no jornalismo produzido na redação trazem novas possibilidades de aprofundamento da matéria, integração de diferentes linguagens (áudio, fotos, charges, textos, fac-símiles) e maior interação com o público. Essas inovações estão sendo absorvidas no trabalho observado na redação virtual, que tem privilegiado a organização do trabalho também por linguagens.

A transmissão ao vivo proporcionada pelas redes sociais é muito utilizada por dois dos arranjos pesquisados e fazem parte de estratégias narrativas distintas. No Jornalistas Livres está relacionada ao conceito de verdade e veracidade. "Somos os herdeiros de Glauber Rocha e uma ideia na cabeça e uma câmera na mão mostra o fato como ele está acontecendo", defendeu Mônica Galvão (2018). ${ }^{85}$ Para o Opera Mundi, a transmissão ao vivo está relacionada a uma política que visa audiência no Youtube e muitas vezes nos acontecimentos especiais a transmissão é feita a partir de outra página.

A concorrência apontada por Ganz (1979, p. 177), como um dos critérios definidores da notícia, tem outra dimensão mais ampla do que a cobertura de um acontecimento. Na mídia alternativa, as demarcações são sobre as diferenças de fundo editorial, sobre as formas de organização, atuação e ativismo na disputa por colaboradores. Sobre a produção de conteúdo, há sinergia em pautas e coberturas com a organização de centrais de mídias em que o trabalho é organizado coletivamente. Embora não seja cotidiano esse tipo de alinhamento acontece em momentos de extrema polarização política ou quando a pauta é cara para o conjunto dos movimentos. ${ }^{86}$

Na relação entre os arranjos alternativos há a intenção de fundar e criar espaços de mídia voltados para alguns temas específicos. O Jornalistas Livres contou com o estímulo e apoio inicial da Agência Pública e do Mídia Ninja; o Outras Palavras serviu como “incubadora" para o site De Olho nos Ruralistas. Esse fato se dá por entender que cada veículo só pode ser efetivo e forte se houver outros sites e veículos fortalecendo esse tipo de produção de comunicação. Nesse aspecto, a solidariedade é que conta e não a concorrência.

O sistema de fontes presente na mídia alternativa varia com a organização do arranjo. No Jornalistas Livres, por ser maior e ter organização em rede, essa relação é combinada entre

\footnotetext{
${ }^{85}$ Informação verbal coletada em seminário que estivemos juntas como palestrantes.

${ }^{86}$ Durante a cobertura do impeachment em Brasília foi organizada uma central de mídia que, em seu conjunto, foi a maior de todo espectro do jornalismo.
} 
leitor-editor, que ao mesmo tempo é público da matéria e é também fonte e partícipe da elaboração da informação que lhe interessa. São lideranças dos movimentos sociais que procuram os JL por saber que é o canal que acolhe esse tipo de informação, são especialistas em determinados temas e veículos de comunicação da grande mídia. Para a Agência Pressenza, as fontes são os colaboradores voluntários organizados ou não no movimento humanista, agências de notícias internacionais, especialistas e lideranças políticas alinhadas com a política da Agência. Já para o Opera Mundi, as fontes são veículos progressistas da América Latina e de alguns países que são frequentes como Alemanha, Rússia, Estados Unidos, China, agência internacionais e especialistas em geopolítica internacional, além da grande mídia; e no Outras Palavras são fontes acadêmicos, portais de universidades, principais jornais internacionais, agências de jornalismo investigativo. Todos os arranjos estudados utilizam como fonte sites da mídia alternativa.

Além de identificar tensões e modificação na teoria do newsmaking também inferimos mudanças na teoria do gatekeeper por perceber que esse portão (significado da palavra gate), se não se transformou por completo, teve sua abertura escancarada com o uso da tecnologia e renovações das rotinas produtivas. É fundamental perceber que as tensões advindas da tecnologia de informação e comunicação, não são específicas da mídia alternativa, mas sim pressionam todo processo produtivo do jornalismo a se movimentar e ser alterado.

Foi a partir de estudo elaborado por Kurt Lewin sobre as mudanças dos hábitos alimentares em grupo social específico, em 1947, que foi possível a compreensão do uso de filtros de acordo com a existência de comportamentos que seguiam por canais até chegar aos filtros controlados por quem tinha poder de abri-lo ou não.

Utilizando o caso do portão e porteiro elaborado por Lewin, David Manning White, após três anos, analisou o fluxograma da notícia sendo capaz de identificar os canais de organização e os motivos para a pauta seguir até a sua publicação ou ser arquivada. Em seu estudo, o pauteiro "Mrs. Gates" cumpria a função de porteiro e de cada dez, nove matérias eram rejeitadas com base em alegações de falta de espaço, interesse jornalístico, repetição do assunto ou mesmo tempo para escrita da matéria.

Para Wolf (2012, p. 185), a contribuição dessa teoria foi de "[...] individualizar onde, em que ponto do aparelho, a ação do filtro é exercida explícita e institucionalmente." Isso significa que o poder de barrar ou fazer progredir a pauta não é do sujeito, do jornalista, porém é amparado no processo hierárquico e articulado com os interesses gerais, específicos e com a linha editorial definida pela corporação de mídia. O sociólogo italiano perpassou por 
diferentes estudos sobre a teoria do gatekeeper e, embora sejam antigas e ancoradas em televisão e jornal, seus resultados ainda são válidos para ampliação conceitual da teoria ao incluir todas as formas de controle da informação, "que podem ser determinadas nas decisões sobre a codificação das mensagens, a seleção, a formação da mensagem, a difusão da programação. A exclusão de toda a mensagem ou dos seus componentes" (DONOHUE; TICHENOR; OLIEN, 1972, p. 43 apud WOLF, 2012).

$\mathrm{Na}$ atividade cotidiana do jornalista da mídia de massa, visto novamente que o foco dessas pesquisas foram os espaços da chamada grande mídia, os conflitos e determinantes sobre a evolução da pauta estavam relacionados a adesão pragmática do jornalista aos ideais do proprietário da empresa de comunicação, a noção de prestação de serviço e fidelidade aos seus chefes diretos; a pretensão de evolução na organização e aumento de salário e por aferir o valor da notícia publicada (BREED, 1955 apud WOLF, ibidem).

Embora também haja na redação virtual o desejo da evolução profissional, ele é relacionado à importância conferida pelo jornalista à necessidade de existência do arranjo, à sua transformação política real e ao seu papel na disputa de opinião dentro da arena de lutas da sociedade civil. Ou seja, associar a pauta à política editorial também é fator determinante para seguimento da matéria, mas esse processo não é feito em vista de alguma benesse ou uma promoção, como na redação tradicional, mas com interesse de reforçar aspectos da cobertura do posicionamento individual e editorial do veículo.

Outro fator é o estímulo à participação de seus leitores. Ao invés de ter um porteiro dizendo o que é ou não notícia, baseado em decisões corporativas, nos arranjos alternativos há o esforço de convidar o leitor para que ele se torne um editor. Os quatro arranjos analisados nessa pesquisa estimulam a participação do leitor como elaborador da notícia. As táticas utilizadas variam desde a abertura de redações para cobertura especiais (Jornalistas Livres); chamada ampla para reunião de pauta (Agência Pressenza e Jornalistas Livres); política de relacionamento exclusiva com seus colaboradores (Outras Palavras); e seleção particular de jornalistas que já estão em seu arco de influência política (Opera Mundi).

Os leitores com acesso ao maquinário para elaborar a matéria e ampla base de consulta de informação deixa de ser passivo e mero telespectador no velho esquema de comunicação um para um e passa a ter interface com uma rede de comunicação. Isso é valorizado e estimulado na redação virtual ao arranjo alternativo, a criação de novas redes e demarca a concepção de jornalismo existente na redação tradicional, cujo profissional da área é aquele 
com diploma ou larga experiência nos grupos monopolizados de mídia e encara o leitor como subproduto e não como interlocutor.

Quanto mais o leitor participa como editor na atividade jornalística do arranjo, mais o arranjo adquire qualidades e expertise em temas tornando-se referência e fonte na camada social em que está inserido o leitor.

Outra questão que tem alterado a teoria do gatekeeper é a emersão de temas em blogs e sites de redes sociais, compartilhamento em massa de fatos e acontecimentos que devido à sua repercussão acabam por pautar todo espectro da imprensa. (como foi o caso Cláudia da Silva Ferreira, uma moradora do Morro da Congonha, no Rio de Janeiro, que foi arrastada pela viatura em movimento e filmada por um motorista, cujo caso pautou todo espectro da imprensa). Nessa mesma linha há também situações em que a mídia alternativa adentra ao portão da mídia corporativa com ação unificada de vários sites e coletivos que pautam ao mesmo tempo um acontecimento ou denúncia, como foi no caso do vazamento de óleo na Bacia de Campos, provocado pela petrolífera norte-americana Chevron, assunto estratégico que demorou mais de cinco dias para entrar na pauta das grandes corporações de mídia.

Em vista da análise do procedimento da pauta na mídia alternativa, reconhecemos mudanças estruturais na teoria do gatekeeper. Essas mudanças apontam para inovações para o jornalismo como um todo.

Como podemos identificar, há mudanças quanto à cultura profissional na redação, local de conflitos e tensões das relações de trabalho, onde se mostra a precarização estrutural do trabalho, porém também é o local de formação e de posturas mais solidárias entre os profissionais do próprio site ou coletivo; mais aproximações entre o sistema de fontes, público e outros meios com a atuação conjunta na elaboração da matéria jornalística; na organização do trabalho com outro fluxograma e hierarquia no espaço virtual, que estimula a construção de redes; e no processo produtivo em si, com a criação de novas funções e obrigações a partir de saberes normatizados e reformulados a partir da situação concreta de cada arranjo considerando seus objetivos e natureza.

Em meio a mudanças é preciso compreendermos também qual é o sentido do jornalismo produzido nos arranjos alternativos de comunicação. A questão “o jornalismo está em crise" esteve presente durante todo processo de observação participante. 
A crise é do capital e provoca ações, reflexos e mudanças em segmentos distintos, configurando momento de transição, uma briga de contrários, como o pêndulo do trabalho do jornalista que traz inovações, incômodos e sofrimento.

\section{Sentidos do jornalismo}

Durante toda a observação, notamos que a palavra 'jornalismo' adquire diferentes sentidos. Para designar jornalismo apareceram: jornalismo profissional e não profissional, de massa, digital, hiper midiático, jornalismo como mídia de combate, mídia alternativa, jornalismo de análise, jornalismo hardnews, jornalismo de reinterpretação, jornalismo institucional, jornalismo internacional.

Isso demonstra os conflitos em torno do sentido do jornalismo. A resposta para a pergunta "O jornalismo está em crise?" não foi consensual em nenhuma redação que analisamos. Chegar até esse ponto de nossa observação com a interrogação denota as suas constantes mudanças e os sentidos apontados pelos profissionais.

As teorias da área apontam para o jornalismo feito nas redações das grandes corporações de mídia como o único jornalismo possível. É raro vermos a aplicação das teorias em redações descentralizadas ou espaços alternativos.

\footnotetext{
É muita gente que está observando e fazendo circular os jornalistas no sentido lato do termo e ao mesmo tempo que isso está acontecendo. Então, a multiplicação das vozes é o que faz que a gente esteja vivendo uma nova alvorada do jornalismo. Isso não significa que a gente esteja vivendo uma nova alvorada do jornalismo profissional, acho que não. Acho que o jornalismo profissional no Brasil está vivendo a maior crise da história. Ou são as redações que estão sendo enxutas ou o fechamento mesmo de redações ou para mim, pior ainda, que é a imigração de manadas de formandos nas escolas de jornalismo indo trabalhar para assessorias de imprensa, que é tudo menos jornalismo, né? (Mônica Galvão, 2018)
}

A diferença entre jornalismo profissional e não profissional, sustentada por Galvão, sugere, assim como as teorias de jornalismo, que o jornalismo profissional é aquele que acontece em uma grande redação e as relações são mediadas por um contrato jurídico de trabalho que pague a força dispendida pelo jornalista. As marcas do jornalismo feito sob estas condições aparecem no conjunto da formação discursiva da jornalista entrevistada.

Entretanto, segundo o dicionário Houais (2008, p. 663), “profissional” é aquele que é capacitado, conhecedor, entendido, especialista, experto, perito, competente, destro e idôneo. Desse modo, o jornalista profissional não é somente aquele que exerce uma profissão, mas também aquele que executa um trabalho na área da qual é conhecedor. 
Citamos no Capítulo I a diferença entre trabalho e emprego e posicionamos o primeiro como atividade humana e "[...] não como uma realidade simples, sem nuances e historicamente datado, susceptível de caracterização unilateral" (FÍGARO, 2008, p. 120).

Não é porque as relações não são mediadas pelo salário que o jornalismo na mídia alternativa é "amador", como classifica Mônica Galvão. Pelo contrário, constatamos muitos elementos que colocam a competência e expertise do jornalista em outro patamar e renovação do jornalismo por diferentes fatores, desde as mudanças proporcionadas pela falta de estrutura até o sentido ético e solidário da profissão.

Para Galvão, o jornalismo profissional das redações está na maior crise da história. Mas como vimos, a crise é produto da gana lucrativa das famílias proprietárias desses veículos que estão migrando para outros tipos de negócios e conservando os meios de comunicação para qualificar o valor das suas transações econômicas.

A percepção de crise é corroborada por João Felício que julga ser o avanço das tecnologias de informação e comunicação o motivo da instabilidade do jornalismo. Em suas próprias palavras:

Está, com certeza, é evidente. Está numa crise, inclusive essas eleições mostraram que ele perdeu radicalmente espaço como formador de opinião, como fonte de informação. As redes sociais são o novo polo de controle ideológico, que a gente está vendo aí na sociedade e isso daí mudou muita coisa. As pessoas estão se informando pelo WhatsApp, por internet, por Facebook, e isso daí acaba acarretando problemas financeiros para os veículos de mídias tradicionais. (João Felício, 2018)

A crise do jornal impresso e a exigência de um processo industrial não podem ser confundidas com o declínio do jornalismo como um todo. Dentro das redes sociais, os monopólios de comunicação, ao mesmo tempo em que geram valor para os proprietários dessas redes também aproveitam para potencializar a circulação do seu conteúdo e receber mais visitantes em suas plataformas. Basta ver o número de leitores que chegam aos produtos digitais através de links de rádio, televisão, sites. Todos os últimos capítulos de novela da Rede Globo, por exemplo, tiveram termos relacionados entre os mais usados no Twitter.

Contudo, não podemos naturalizar o uso dos algoritmos no processo de comunicação que é utilizado por esses sites para definir quem recebe tal ou qual tipo de informação. $\mathrm{O}$ papel de mostrar o que é notícia ou não nessas redes passa a ser mediado pela programação algorítmica. O jornalista trabalha na pauta, mas nesses espaços quem define quem vai receber essa notícia não é mais o profissional, mas a mediação feita através de um arcabouço de preceitos e a venda de dados desse potencial público leitor. 
Esses dados são hoje a nova moeda que sustenta as cinco primeiras empresas dentre as dez maiores do mundo por capitalização de mercado. Como vimos na análise da reestruturação produtiva, essas empresas se colocam como a solução da crise do capital desencadeada em 2007.

Embora Leonardo Santos divida o espaço de trabalho com o Paulo Correia, a sua visão sobre crise do jornalismo é outra. O jovem, que está em seu primeiro estágio na área, defende que essa instabilidade é um "discurso construído".

\begin{abstract}
Eu acho que não. Talvez seja um discurso construído. Por mais que tenha mudado, os jornalões não vendem o quanto vendia, que a Globo não tem mais a capilaridade que ela tinha por que a internet planificou um pouco mais isso. Eu acho que o que está em crise na verdade é o sentido da profissão e não o jornalismo em si. As pessoas estão saindo da faculdade com outra visão achando que jornalismo é Twitter e não é bem assim, o trabalho de repórter é sempre trabalho de repórter, independentemente de onde ele vai publicar, no Twitter, no Opera Mundi, no Head (inaudível) ou na Globo. (...) O jornalismo não está em crise, o que está em crise é a cabeça das pessoas, o ofício. As pessoas estão saindo da faculdade e dizem tá, mas eu queria ser a Fátima Bernardes, trabalhar com entretenimento. E não é assim, jornalismo é um pouco mais de chão. (Leonardo Santos, 2018)
\end{abstract}

Ainda na universidade, o jornalista demonstra certo incômodo intelectual com as mudanças na percepção de seus colegas sobre o que é jornalismo e o sentido da profissão que, segundo sua avaliação, tem perdido o sentido na ausência de acontecimentos relevantes e a produção de conhecimento através do trabalho do jornalista.

Em meio às mudanças e as ameaças de notícias falsas que circundam as disputas políticas e enfraquecem processos democráticos, como vimos na última eleição brasileira, Luiz Graciliano (2018) aponta o retorno do jornalismo que tem posição ideológica clara ou referências que sejam fonte de confiança e credibilidade através do trabalho do jornalista de coletar, criar e articular a informação a partir de um ponto de vista explícito.

[...] você tem que ter algumas referências em quem você confie, em quem você se identifique para enxergar a realidade a partir do ponto de vista semelhante ao teu. Então, por isso que estão surgindo esses boletins, tipo o Meio, tipo o Nexo, no exterior surgiram antes, tem o New York Times tem ((ruído externo)). Eu identifico como uma possível tendência, eu acho até positiva, é você retomar, digamos assim, um jornalismo do ponto de vista claro e uma confiança no trabalho jornalístico de coletar informação, criar a informação e articular a informação a partir de um ponto de vista explícito. Ao invés de você sair catando borboleta na internet, muito mais nas redes sociais. (Luiz Graciliano, 2018)

Não há unidade em torno da possível crise do jornalismo, mas há forte consenso sobre as mudanças do jornalismo e da importância do jornalista como mediador de uma realidade que a área ajuda a construir e a transmitir conhecimento. 
A concepção de matéria jornalística nas redações analisadas é de que a pluralidade e diversidade de informação é um direito e não uma mercadoria. Esse é o principal substantivo que diferencia a produção da notícia nos arranjos alternativos.

Conforme Adelmo Genro (2012, p. 203), “[...] o jornalismo é fruto dos interesses burgueses e também de necessidades sociais profundas [...]" no sentido de um conflito potencial com a mera reprodução ideológica das relações vigentes.

A concepção de jornalismo como conhecimento implica em reconhecer o seu papel na disputa e reforço de sentidos, visando a adesão dos sujeitos ao sistema. De acordo com a teoria desenvolvida no livro $\mathbf{O}$ segredo da pirâmide: para uma teoria marxista do jornalismo, o jornalismo é por excelência a ideologia da objetividade e expressa a ideologia dominante, mas também as suas contradições e "[...] enquanto se aprofundam as contradições do capitalismo, o jornalismo tende a refletir espontaneamente aspectos críticos da própria objetividade que reproduz.” (idem, p. 189)

Assim como o professor da Universidade de Santa Maria, a concepção dos jornalistas é que o jornalismo é uma forma de apreensão da realidade que gera conhecimento sobre cotidiano, mas também do embate de classes que estamos inseridos, possibilitando condições para que os indivíduos possam fazer escolhas a partir desse processo infinito de conhecimento acerca de um recorte da realidade social entendida como realidade concreta, “[...] como transformação da possibilidade e probabilidade em liberdade através da criação e superação permanente de necessidades por meio do trabalho.” (idem, pp. 195-196)

A partir desse ponto de vista, a produção jornalística dos arranjos alternativos tem poderoso valor de uso para a sociedade contemporânea, entretanto é possível verificar que o seu valor de troca adquire relevo nas plataformas de redes sociais, através dos dados e informações geradas, mas não chega a intervir na sustentação desses veículos.

Diferentemente das informações e dados gerados a partir do uso e consumo no ambiente digital, o trabalho jornalístico produz informações compreensíveis para um público amplo. Essas informações são úteis para criar valor para essas empresas, como Google e Facebook.

Vimos no Capítulo III que, para criar valor de troca, os membros da Agência Pressenza tiveram que fundar outro arranjo econômico para entrar na cadeia de valor global e ser possível tornar-se equivalente a valor de uso de prestação de serviços. O trabalho, dentre as relações capitalistas, é a única mercadoria especial que gera mais valor. Para explorar esse aspecto, a agência também começou a fazer parte de um processo mais amplo representando 
um espaço de precarização de trabalho explorado, principalmente pela polivalência e engajamento total.

Ao explicitar suas ideias sobre valor de uso, valor de troca e mercadoria, utilizando o exemplo do linho, Marx aponta que “[...] para expressar o valor do linho como massa amorfa de trabalho humano, tem que ser expressão como uma objetividade [...]”, diferente do linho e ao mesmo tempo comum a ele e a outras mercadorias (MARX, 2017 a, p. 124).

No Outras Palavras e Opera Mundi, a produção também é encarada como conhecimento. Ambos deixam as suas matérias abertas para todo público e é o trabalho que organiza a sua sustentação e sua política de financiamento.

Os dois têm equipes de trabalho, honram com compromissos de produção, periodicidade, trabalham em torno da criação e articulação de informação e apresentam de forma sistematizada para seu público leitor. Esse serviço é uma necessidade para um conjunto de pessoas que doam recursos para manter os sites.

No Jornalistas Livres a necessidade é de ter um espaço que possa receber os jornalistas que acreditam na profissão como função social e, por isso, fazem do coletivo espaço de práxis social e doam o seu trabalho para criar notícias ao mesmo tempo em que criticam as corporações de comunicação. Esse foi o arranjo no qual constatamos maior presença de jornalistas que já trabalharam nos espaços tradicionais da grande mídia e também onde o valor do trabalho é menos aparente por se tratar de um espaço no qual o trabalho é voluntário, uma militância em que a régua não é a mesma por não ser equivalente e uma mercadoria dissimulada.

Não é apenas uma necessidade individual, é coletiva e pode cumprir papel de aperfeiçoamento da democracia por apresentar temas e discussões ausentes nos veículos tradicionais e novas visões sobre o mesmo recorte social como fenômeno.

Em meio a desertos de notícias onde milhões de pessoas não têm nenhuma informação de suas cidades ou regiões, a elaboração de políticas públicas que passem pela ampliação nas relações democráticas e culturais é fundamental para a evolução da sociedade.

Por isso, é fundamental o Estado garantir a presença e atuação de outras fontes de informações plurais e diversas, deslocando setores arraigados nas estruturais estatais desde o início da imprensa brasileira, que julgam serem somente eles a voz da sociedade quando, na verdade, utilizam esse espaço para garantir a manutenção do bloco histórico do qual fazem 
parte. O Estado sempre contribuiu para o desenvolvimento das forças produtivas de comunicação no Brasil. Do estímulo à compra de papel com créditos agrícolas, como aconteceu no primeiro governo de Getúlio Vargas, à destinação de verba publicitária para a chamada mídia técnica, o Estado sempre pagou a conta desse negócio.

É importante destacar que o valor da mercadoria notícia também está inserido no contexto da crise do capital e suas consequências no jornalismo. A remonetização da informação proveniente da centralidade da tecnologia é fulcral para tornar invisível a geração de valor na cadeia do capital. Mensurar o valor de troca do trabalhador da informação com as atribuições de jornalista está mais complexo e menos aparente.

Para sustentar o trabalho cotidiano de jornalistas, os arranjos analisados usam o serviço de assinaturas (Opera Mundi), relacionamento com doação e recompensa com catálogo de serviços e produtos como contrapartida (Outras Palavras), campanha de doação via crowdfunding ${ }^{87}$ (Jornalistas Livres fez uma única campanha em 2015, cujo valor arrecadado foi de $\mathrm{R} \$ 150$ mil) e outros arranjos que vendem serviços para manter o projeto coletivo (Agência Pressenza).

Com apenas um financiamento, o Jornalistas Livres tem reserva desse recurso até o final da fase de entrevista dessa pesquisa. Isso se dá porque o dinheiro arrecadado é destinado apenas para financiamento da passagem, quando não conseguem viabilizar doações pontuais para bancar o andamento da pauta. Todos os outros serviços, sites, hospedagem do site, criação da identidade visual, por exemplo, foram serviços doados por profissionais ao arranjo.

Os arranjos produtivos de comunicação tornam possível a realização de um jornalismo que se contrapõe ao que é feito nas redações profissionais, gerando conhecimento ao dar vozes e jogar luz em acontecimentos silenciados pela mídia hegemônica, atuando em mais de um local de trabalho e áreas da comunicação como verificamos no curso da análise.

Há outros setores interessados na forma de trabalho e produção de arranjos, como os que fazem parte da nossa análise, devido ao papel do jornalismo nas transformações da sociedade e ao estimular a adesão ao sistema capitalista.

"Nós não queremos e não aceitamos dinheiro das fundações internacionais, porque sabemos bem o que tem por trás desse interesse. Não queremos dinheiro da Ford, do Soros, não queremos", afirma Mônica Galvão (2018).

\footnotetext{
${ }^{87}$ É a famosa vaquinha que no contexto digital alia doação de pessoas físicas interessadas em manter projetos coletivos, banco de dados de doadores e marketing digital. O serviço é feito através de plataforma de arrecadação de recursos.
} 
São empresas que têm interesse em "[...] associar sua imagem ao jornalismo, que tem um valor de veracidade, a empresa, de certa forma, se favorece com esse valor e no sentido de estimular mudanças micro ou macrossociais que favorecem interesses internos de instituições e empresas." (FÍGARO, 2018. p. 210)

Uma dessas fundações - a Ford Foundation - decidiu atuar fora dos Estados Unidos a partir de 1951 e entre os eixos decisórios constava “[...] aplicar os seus recursos em determinados países e na solução de determinados problemas, cumprindo sua missão de construir os instrumentos sociais do progresso." (BROOKE, 2002, p. 12)

O contexto dessa decisão estava permeado pela corrida armamentista, crise dos mísseis, guerra do Vietnã, corrida espacial e o embate direto entre Estados Unidos e a então União Soviética, que protagonizavam uma guerra ideológica entre dois tipos de sistema de produção econômico. O jeito americano de vida, as benesses do liberalismo, da economia de livre mercado em contraposição ao "autoritarismo" e à "ditadura do proletariado", esse era o pilar da estratégia de comunicação do governo norte-americano que, através da Central Intelligence Agency (CIA), patrocinava atividades culturais na Europa e outros países-chave para efetivar a sua estratégia, sobretudo, na América Latina.

Para mobilizar a cultura como arma na guerra fria, os Estados Unidos contaram com a “[...] organização sistemática de uma rede de grupos ou amigos particulares num consórcio não oficial [...]”, com a participação de empresários e suas instituições filantrópicas, registrada no livro Quem pagou a conta? A CIA na Guerra Fria Cultural, de Frances Stoners Saunders.

O papel das fundações era de disfarçar a direção do Estado norte-americano na disputa cultural e ideológica. Em 1963, a relatoria da Fundação explicita que o objetivo número um do seu processo de internacionalização é de cumprir a sua função além de seu país de origem, sendo "[...] uma vitória vazia se o resto do mundo continuasse sujeito à miséria e às agitações (com grifo nosso)" (FORD FOUNDATION apud BROOKE, 2002).

Os trabalhos no Brasil começaram em 1961, e o primeiro espaço para doações foram as universidades e setores da agricultura com a chamada "revolução verde" a partir da ideia de que o desenvolvimento na América Latina sofria com déficit na formação em economia aplicada, ciências políticas, pesquisa marítima, direito, administração de empresas, engenharia industrial, entre outras áreas em que era preciso evoluir no país para poder entrar na cadeia econômica norte-americana. 
Em 1990, o foco passa a ser as organizações não governamentais que representavam setores excluídos das políticas públicas estatais, em pleno desenvolvimento do neoliberalismo e venda do patrimônio nacional. Com o crescimento desse tipo de entidades no chamado terceiro-setor, além das fundações, o Banco Mundial e órgãos da ONU, como UNESCO e UNICEF, também passaram a privilegiar esse segmento para doações de recursos. É dessa data o aumento de investimento com bolsas, fomento e patrocino de pesquisas relacionadas à questão de gênero, igualdade racial e educação, contribuindo com a lógica individualista e segmentada dessas questões em associação ao avanço das saídas neoliberais. O objetivo era fortalecer as entidades da sociedade civil, separando-as do aparato estatal, mas principalmente apartar as suas lógicas do contexto da luta contra a exploração.

A partir de 2003/2004, a Fundação Ford passou a investir também em uma nova linha denominada "direitos de mídia", que visava a "[...] consolidação da democracia, a partir do fortalecimento da sociedade civil e, em particular, dos grupos subrepresentados, das minorias." (PORTO, 2011, p. 176) A comunicação foi agregada ao portfólio de doações com o objetivo de criar uma rede articulada da sociedade civil para discutir políticas públicas de comunicação que não fossem polarizadas “[...] pelo mercado e Estado.” (ibidem, p. 179)

A matriz política de atuação internacional da Fundação é "Educação, Criatividade e Liberdade de Expressão" e o tripé impulsiona a organização para capitanear as mudanças tecnológicas como “[...] instrumento de promoção social no mundo.” (PORTO, op. cit.).

Mais uma vez, o propósito da Fundação é desviar a discussão sobre a representação das grandes empresas de comunicação no processo de valorização do capital, rebaixar a função do Estado como indutor da diversidade e pluralidade de informação ou, em muitos casos, dissimular o seu papel de censor da liberdade de expressão.

A questão chave para a Fundação Ford, ao invés de posicionar o Estado dentro do processo de ampliação da democratização da comunicação, é justificada "[...] porque os cidadãos não estão tendo capacidade efetiva de receber uma diversidade de perspectivas, informações e opiniões." (idem,) Com essa abordagem, desloca o problema do Estado e do sistema para o plano do indivíduo, passando novamente a responsabilidade ao sujeito, segmentando um problema estrutural da sociedade contemporânea.

O financiamento é tema chave para entender os arranjos alternativos e o próprio jornalismo. Durante o processo de investigação esse tema transbordou a ponto de fazer parte da definição sobre comunicação alternativa, como veremos a seguir. 
A fonte de financiamento como vimos, é tema que assume centralidade na mídia alternativa porque essa categoria influi em outros como meios de produção e as relações de trabalho. O sentido de financiamento é atrelado ao de independente.

\begin{abstract}
Acho que alternativa e independente. Independente, principalmente na questão financeira, acho importante a questão financeira, a gente não é sustentando por nenhuma empresa, nem por uma família, nem por publicidade praticamente. A nossa maior fonte de arrecadação são os leitores e acho que isso permite que a gente seja independente. [...] E alternativo também acho que é, porque está fora do mainstream... (Leonardo Santos, 2018)
\end{abstract}

A independência é fator crucial para o jornalismo e para a concepção de notícia como conhecimento e não mercadoria. Hoje, de forma geral, esses sites são sustentados por pessoas relacionadas pelo conjunto de ideias expresso no conteúdo do site e coletivo ou por movimentos. Vimos que esse dado geral intervém na formação desse tipo de experiência. Os quatro arranjos analisados tiveram a sua origem em embates sociais.

Se a gente falar de Pressenza, acho que a gente pode falar que é uma agência de notícias, independente do sistema capitalista, mas dependente dos movimentos sociais que a impulsionam, que fazem parte disso. Se não tivessem movimentos, também não faria sentido, porque ela faz parte disso também. Ela nasce desses movimentos e serve para reportar as notícias desse movimento. Então, ela é independente em relação ao sistema, mas ela é dependente desse conjunto de movimentos, que são organizações que a impulsionam. Então, ela é uma alternativa de informação aos meios tradicionais. (Guilherme Almeida, 2018)

Mesmo fazendo parte sistematizando e reportando a pauta dos movimentos, há um limitador que separa a mídia alternativa do movimento social geral, mas não é atribuição da comunicação criar a luta social em si em termos práticos, mas fornecer as bases para uma cultura de resistência.

Não é função da mídia independente criar a luta, é função da mídia independente reportar a luta, visibilizar os invisíveis, fazer a contra narrativa ao que está colocado pela grande mídia. Isso nós podemos fazer e estamos fazendo lindamente. [...] Agora por gente na rua, fazer uma greve geral não vai ser a gente que vai por. (Mônica Galvão, 2018)

A comunicação é alternativa por cumprir papel fundamental na luta de ideias e embates sociais, por isso se contrapõe à comunicação das grandes corporações de mídia, principalmente quanto ao modo de produção e organização de financiamento dos dispositivos comunicacionais para disputar narrativas. 


\section{CONCLUSÕES FINAIS}


Após o tempo determinado para realizar a pesquisa, chegamos até esse ponto com algumas respostas, novas perguntas e muitas reflexões sobre a relação sujeito-objeto, sobre a importância da comunicação, mas também sobre a universidade e o país. Importante destacar que o objeto e a prática conduzem, junto com o sujeito, os rumos da pesquisa.

A primeira consideração é sobre a reflexão permanente durante todo o trajeto da pesquisa. Devido à escolha da combinação de técnicas e da linha etnográfica seguida com observação participante, o percurso até esse ponto foi marcado por tensionamentos, incômodo intelectual e atenção cujo objeto parecia nos tirar para dançar exigindo distância e aproximação, como duas faces do mesmo movimento de estímulo ao pensamento crítico.

A observação participante dos arranjos alternativos à comunicação, os quais compreendemos serem essenciais para a pluralidade e diversidade de opinião e ao funcionamento da democracia, exigiu ainda mais vigilância e até certo despojamento de 'certezas' empíricas, tendo a dúvida como nossa parceira de campo em um processo de permanente autocrítica e reflexão sobre o métodos, caminhos e embates.

Um desses confrontos, à primeira vista, parecia ser sobre o léxico utilizado na escrita, porém, ao ser encarado sobre suas diversas dimensões, percebemos que o problema era muito mais profundo. Deparamo-nos com as seguintes questões: por que não utilizar expressões como luta de classes, classes sociais, classes subalternas? Como falar de hegemonia sem falar de Lênin? Sem falar do objetivo da construção do bloco histórico? Ou ainda como citar esses autores sem parecer dogmático? Por que toda vez que o argumento requeria essas referências a vigilância epistemológica era transvestida de tantas dúvidas como essas?

Se a academia for considerada um campo independente, não vamos encontrar essas respostas nela mesma. Contudo, se percebemos a universidade como um espaço cujas relações sociais dominantes agem, predominam e se perpetuam entenderemos a ênfase geral dada a determinados paradigmas e à invisibilidade conferida a outros autores e outras linhas de pensamentos.

No entanto, ao entrar em contato com autores decididos de seu lugar na ciência como alguns usados como referência, adquirimos envergadura teórica para seguir a linha de análise em que o compromisso é exclusivamente com a produção de conhecimento. 
A vigilância epistemológica também é necessária para descortinar os caminhos e deixar o problema de pesquisa fazer esse processo conjuntamente com o pesquisador na seleção de técnicas e da abordagem teórica e metodológica.

Dessa forma, um dos compromissos gnosiológicos desde o primeiro passo da análise era colocar no foco da pesquisa um pedaço do Brasil, uma parte da comunicação social que ainda é estudada de forma lateral na academia.

Posicionar a comunicação alternativa, explorar os seus aspectos, escutar o objeto, identificar o que ele tem para mostrar e fazer isso com metodologia dentro de uma das principais universidades do país corrobora para colocar a ciência a serviço da sociedade. A análise é o apoio para transformação da realidade social. Como Karl Marx (1986) apontou, não cabe só ao cientista interpretar, mas mudar o mundo.

Um dos empecilhos para mudanças mais radicalizadas é o alto nível de individualismo, segregação cuja expressão popular "cada um no seu quadrado" é emblemática do nível de segmentação da sociedade.

A busca por diversidade ao invés de igualdade é fator que divide e separa na prática cotidiana forças que estão posicionadas no mesmo bloco. $\mathrm{O}$ chamado jornalismo de nicho também é, em certa medida, reflexo do aprofundamento das diferenças em busca da diversidade.

Portanto, é importante reafirmar que, através do binômio comunicação e trabalho, conseguimos identificar o que une, estrutura e generaliza o conceito de comunicação alternativa. Desse modo, uma das considerações é sobre o potencial dessa abordagem teórica e metodológica.

Sem essa concepção de pesquisa não teríamos feito um mergulho em experiências históricas para procurar os elementos gerais e particulares, utilizando o materialismo histórico e dialético como escafandro para aprofundamento da análise.

\section{A mídia alternativa para além de 1964}

Ao definir o binômio comunicação e trabalho como aporte teórico e metodológico de pesquisa do processo produtivo e o uso dos meios de produção em determinados contextos históricos, podemos inferir que as várias experiências alternativas estão alocadas sob o 
conceito-sede (CANCLINI, 2016) de comunicação alternativa, sendo esta não um tipo de mídia, mas o sentido maior que abriga as iniciativas e experiências contra-hegemônicas.

A utilização de um espaço conceitual mais amplo não significa a minimização das nuances existentes entre o jornalismo independente, mídia alternativa, comunicação comunitária e popular, mídia sindical e tantas outras definições que possuem mais articulação do que distinção quanto às práticas produtivas e ao posicionamento dentro de um bloco histórico que busca ser hegemônico.

A discussão que fizemos no Capítulo II, sobre mídia alternativa seguindo um caminho histórico cujos veículos de comunicação de outrora se aproximam de arranjos atuais com características estruturantes semelhantes como a produção marcada por trabalho militante e voluntário, problemas estruturais para manter a periodicidade, os objetivos atrelados a embates políticos de contextos predeterminados, entre outros aspectos levantados, demonstrou-se importante para percebermos que a mídia alternativa existiu antes, durante e depois de 1964.

Portanto, o caminho histórico percorrido e a utilização da chave analítica comunicação e trabalho proporcionaram identificar o discurso alternativo atrelado somente ao contexto de resistência. Esse fato, no cenário atual de rebaixamento da política, faz com que o próprio sentido de mídia alternativa seja refratado. Alargar o conceito contribui também para o reencontro da memória e da história dessas experiências.

Dessa maneira, a situação micro e macrossocial do trabalho revelam essas diferenças sem colocá-las em oposição. O clássico exemplo da rádio comunitária que é instrumentalizada por lideranças políticas ou comerciantes locais pode ser encarado como uma atividade que, ao mesmo tempo em que tem essas influências, atua na constituição cultural da comunidade em que está inserida. Isso demonstra como interesses hegemônicos atuam de forma diversificada em organizações populares e comunitárias como espaço e forma de reiteração de discursos conservadores.

As diferenças entre as experiências não as invalidam no sentido geral de comunicação alternativa e, por isso, não vamos classificar de forma arbitrária e dogmática qual é legítima ou não. O objetivo foi refletir sobre as questões que podem aglutinar a ponto de fazer emergir categorias de análise capazes de proporcionar distanciamento e generalização de feições estruturantes para compreensão dos arranjos alternativos.

Sem analisar a correlação de forças da arena de lutas sociais e a tradução dessa relação no processo de produção não é possível demarcar e identificar as características contra- 
hegemônicas. É fato que no hegemônico há sempre aspecto contra-hegemônico, assim como o contrário também é verdadeiro.

O exemplo que utilizamos do primeiro jornal independente do país de Hipólito da Costa nos mostra o potencial da generalização do conceito de alternativo ao analisar a situação concreta, dentro de uma correlação de forças específica. O jornalista precisava trabalhar em outro local para manter a sua atividade no jornal, para aquela circunstância específica, o 'Correio Brasiliense' está em bloco distinto daqueles que estavam no poder durante a fase colonial em que os jornais existentes defendiam o país como subsidiário de Portugal.

Da mesma forma se verificarmos a comunicação feita nas comunidades eclesiais de base, nos jornais que buscavam abolir a escravatura, nos primeiros meios de comunicação cuja base editorial era igualdade de gênero, os veículos anarquistas, sindical vamos encontrar seus 'herdeiros' hoje no jornalismo feito nas periferias, nos que buscam falar com mulheres etc. São inúmeros exemplos existentes cujos elos podem ser estabelecidos.

Se analisados longe de um método histórico e dialético, com base apenas em categorias subjetivas, teremos dificuldades em constatar os elementos gerais que os aproximam de experiências e ficam sob o guarda-chuva da comunicação alternativa.

Dividir a mídia alternativa em muitas caixas nos deixa em múltiplos lugares, porém isolados dentro das singularidades de cada uma. Fizemos o movimento contrário no qual as incursões e particularidades puderam reverberar numa conjugação mais ampla, com um olhar ampliado onde o trânsito entre as experiências é rico e necessário.

\section{A dialética do trabalho do jornalista: contradições e inovações}

A questão que dá linha lógica à pesquisa é como se dão as relações de comunicação e trabalho dos jornalistas que atuam em arranjos de comunicação alternativos às corporações monopolizadas e oligopolizadas de mídia? Ancoradas no problema chave, outras questões secundárias complementaram nossa análise como, por exemplo, as relações de produção da forma discursiva jornalística, a descrição do processo desde a seleção do assunto até a elaboração final do discurso jornalístico, as noções e pilares do jornalismo acionados para construção da matéria e, por fim, quanto ao financiamento, as relações e recursos mobilizados para garantir o financiamento desses veículos e qual a influência dessas relações na produção. 
É importante considerar que há contradições importantes nesse processo. Uma delas é a distância geracional entre quem dirige esses arranjos e os outros membros que geralmente são mais novos. Após anos trabalhando numa grande corporação, algumas práticas desse espaço passam a ser também característica da redação da mídia alternativa.

Por exemplo, em todos os principais eventos, a jornalista Mônica Galvão é quem representa o coletivo Jornalistas Livres. Considerando que o capital simbólico é o principal ativo da relação entre os membros, ser o rosto e a "marca" JL diz muito sobre o processo de constituição do arranjo e sobre a sua organização.

Também é uma contradição latente o fato de uma esfera do Jornalistas Livres, o grupo "Vegetarianos", considerada a secretaria administrativa, não estar clara para todos os voluntários do arranjo. Isso faz com que a atividade de trabalho tenha uma parte alienada do conjunto da atividade.

Contudo, é necessário ressaltar que apreendemos muitas inovações jornalísticas e organizativas na atividade de trabalho do JL. O fato de ter um grupo que tensiona o tempo todo o jornalismo é uma das principais renovações.

Outra antítese é a forma como a abertura para novos membros é realizada no Opera Mundi. A maioria da redação é de estagiários (três de cinco jornalistas) que passaram por uma entrevista de contratação bastante exigente na qual o editor-chefe orgulha-se de ser parecida com a prova de focas $^{88}$ das grandes empresas de mídia. Por ter atuado muito tempo em redações das grandes corporações de mídia, Paulo Correia aplica no arranjo o processo seletivo igual ao da empresa corporativa.

A divisão entre as feições de um negócio próprio e um projeto coletivo que atua através da mídia para conquistar hegemonia são embaralhadas no Outras Palavras. A concepção de trabalho por parte dos comunicadores do arranjo é um embate permanente que esbarra na excessiva centralização do coordenador de redação nas decisões ao mesmo tempo em que ele concede liberdade e autonomia para produção jornalística.

A naturalização da precarização da Agência Pressenza é uma dura realidade. Trabalhar tendo várias funções, polivalência em jornada tripla é considerada pelos comunicadores do arranjo como privilégio. Os entrevistados julgam ser melhor trabalhar em um local que condiz

\footnotetext{
${ }^{88}$ Processo de seleção de estagiários que ocorre nas redações da mídia monopolizada.
} 
com a sua crença e visão de mundo, do que trabalhar sob as mesmas condições em um emprego contrário ao que acreditam.

Para três dos quatro arranjos, é natural não haver divisão entre o tempo de trabalho e não trabalho e as consequências da jornada $24 \times 7$ para a saúde do jornalista que está sempre premido pelo momento, seja o tempo do furo da matéria ou o ciclo da profissão. A mudança sobre a percepção do tempo é um dos temas que merece ser aprofundado. As tecnologias de informação e comunicação contribuem para sua aceleração ou a flexibilidade do modo de acumulação está mudando paradigmaticamente a noção de tempo?

Consideramos esse engajamento total como influência do modo de acumulação flexível e muitas vezes é apresentado pelo mercado como "atributo diferencial do profissional". Contudo, estabelecer como equivalentes o trabalho precarizado simplesmente com o trabalho militante não condiz com a verificação da pesquisa.

Isso porque entre outros objetivos, a concepção de vida e visão de mundo são itens que aproximam os jornalistas na prática profissional. O engajamento militante está relacionado à subjetividade e intenções e devido à sua 'fé' nesses ideais, também tem compromisso com o coletivo no qual está inserido.

Embora seja uma palavra presente nos documentos do espectro da esquerda, militar a “[...] organização do movimento segundo a lógica da guerra" (VALVERDE, 1986, p. 60) pressupõe um campo de embates, com atores posicionados em diferentes posições. $\mathrm{O}$ militante é engajado através de ideias, ele organiza, planeja e atua em ações com uma visão mais ampliada do sistema de forças em que está inserido.

A relação de trabalho pode até ser mediada pelo salário, mas não é a única determinante. Por isso, mesmo compreendendo que o trabalho é sempre estranhado, o conjunto do coletivo em que está inserido o jornalista precisa buscar entender o seu papel no embate entre a classe que detém os meios de produção e a classe que vende a sua força de trabalho no sistema global da cadeia de valor, mas também no processo produtivo da sua própria atividade de trabalho.

Como evidenciamos nos capítulos III e IV, não é o salário que vai significar a relação do jornalista militante, mas o conjunto do processo produtivo. Ademais, tornar aparente a produção jornalística e o trabalho nos arranjos alternativos auxilia para que a sociedade perceba valor de troca, além do valor de uso no trabalho feito pela mídia alternativa. 
Algumas dessas contradições arroladas estão articuladas com as transformações no mundo do trabalho que ensejam em difíceis condições para o jornalista desempenhar o seu trabalho. Contudo, também apontam inovações para a organização do trabalho e para as práticas jornalísticas.

\section{Um novo espaço social do trabalho do jornalista}

Primeiramente é preciso considerar que durante o curso da pesquisa, consideramos todos os profissionais da notícia, que tratam a informação com técnicas e certa normatividade, como jornalistas. Dessa forma, temos como princípio definidor a atividade de trabalho executada. São esses profissionais que formam a redação virtual.

No trajeto da pesquisa, após apresentação da ideia-chave "redação" em congressos e seminários, refletimos se a nomenclatura deveria conter a palavra "virtual" ou redação de plataforma. Como as redações estavam posicionadas em sites de redes sociais fechados como o Telegram, WhatsApp e G-Talk e não especificamente em uma plataforma como Uber e outros serviços, por representar determinada oposição ao espaço físico e se encaixar na chave de análise de trabalho virtual, escolhemos denominar redação virtual o espaço que é destinado para organização da produção jornalística, tendo no mínimo três pessoas. A redação também apresenta características próprias conforme a descrição do Capítulo III e o aprofundamento no Capítulo IV.

É preciso considerar que quanto mais precário do ponto de vista da manutenção, mais dependente é o arranjo de tecnologia para exercer a atividade jornalística, ao mesmo tempo em que essas dificuldades motivam soluções criativas e inovadores.

Em um cenário em que a flexibidade, a mobilidade e o aumento do ritmo do trabalho são crescentes, a redação virtual também cumpre papel de controle das atividades laborais. É o espaço que concentra as práticas inovadoras, mas também as contradições e conflitos particulares dos jornalistas, bem como aspectos gerais existentes nas relações sociais, visto que a redação não está isolada da sociedade.

São nesses espaços, onde encontramos um jornalismo pulsante, que sobrevivem às pressões da falta de financiamento e às tentativas de cooptação das grandes corporações de mídia, cuja lógica da produção é diferente e governa as decisões da elaboração da matéria noticiosa. 
Para os arranjos alternativos analisados, jornalismo é uma forma de transmissão de conhecimento acerca do cotidiano, um espaço comum para que as pessoas possam obter informações e formular a sua opinião.

Diferentemente da estrutura "militarizada" das redações tradicionais, o processo de produção da matéria jornalística da apuração até a distribuição é feito em rede. Muitas vezes a elaboração da notícia é feita entre diferentes arranjos. A colaboração entre a mídia alternativa já existe e é necessária para ampliar a realização de diferentes linguagens e gêneros do jornalismo, como a reportagem que requer mais esforço, concentração e recursos para ser realizada.

Nesse transcurso da produção, o leitor assume papel ativo. Seja como fonte, pauteiro ou mesmo colaborador de matérias com assuntos em que acredita ser importante, para dar visibilidade para tema que elabora ou para receber reconhecimento por escrever para um veículo de comunicação.

As práticas inovadoras do fazer jornalismo também se traduzem em novas atribuições, como vimos no capítulo anterior. Fazer base, facebookar, telegramar, guardiã das senhas, responsável pelo fluxo do conteúdo fazem parte da nova realidade do jornalismo que tem as tecnologias de informação e comunicação como a principal mediação do trabalho. A fala de uma das entrevistadas que sente como as telefonistas do século passado conectando cabos para transmitir ligações evidencia o que é conectar as diferentes editorias na redação virtual.

Parte das inovações implantadas por esses arranjos foi adotada pelas grandes empresas como em outros momentos históricos. Por exemplo, a chamada feita pelo jornalista Willian Bonner com um tutorial para gravação de vídeos e envio ao Jornal Nacional já circulava, pelo menos, há três anos nos veículos alternativos. Casos como esses também aconteceram com a adesão aos conselhos editoriais, a entrada de articulistas nos jornais impressos 'copiados' dos jornais da chamada imprensa alternativa que resistiu à ditadura militar.

Apesar de conter aspectos que são traduzidos por profissionais que trabalharam durante muitos anos na redação tradicional, implicantes principalmente na organização do trabalho, as relações de trabalho nos arranjos alternativos são marcadas por mais horizontalidade, liberdade, autonomia e sentido ético no processo produtivo. 
A organização dessa rotina produtiva que representa alto custo para empresas de comunicação, nos veículos alternativos são encaradas como responsabilidade coletiva. Isso não significa que todos fazem a mesma função, ou a ausência de decisões e métodos engessados que travam o desenvolvimento do arranjo, mas sim que há atribuições diferenciadas que seguem o mesmo sentido de ampliar o alcance, relevância e intervenção da produção na realidade.

Esse fator demonstra o potencial da utilização da tecnologia na configuração de relações de produção inovadoras e horizontais que podem ser apropriadas para conquista da hegemonia e identificar forças que podem contribuir para transformar a sociedade. Os movimentos sociais e sindicais estão longe desse entendimento e representam relações obsoletas ao mesmo tempo em que não apresentam proposições para esta nova realidade do trabalho.

Isso porque a concepção de um modo de produção fordista ainda é muito presente no ideário organizacional dessas entidades que não sabem lidar com a desconfiguração do trabalho, muitas vezes tendo a cadeia de produção dividida em diferentes locais do mundo. A verticalização e certa militarização com posicionamentos engessados são opostas à organização em rede cuja horizontalização é uma marca estrutural que predomina nas relações intermediadas pelas plataformas de redes sociais.

A burocratização em longos e intermináveis processos para ações simples é fator que afasta os jovens da atividade sindical e social. As mulheres são alvos de assédio moral e sexual constante em um cenário que chega a $51 \%$ na sociedade brasileira. Somada a esses fatores, o mais grave é a ausência de discussão sobre as transformações do mundo do trabalho por secretários sindicais, em sua maioria, liberados do local do trabalho há décadas para exercer a função de representatividade da categoria.

Em que pese serem empresas e constituírem uma esfera privada, os sites de redes sociais possuem também dimensões de socialização de conhecimento e novas relações produtivas que podem constituir uma cultura de resistência cujo papel é contribuir com a diversidade e pluralidade de informação para a sociedade em busca de avanços civilizatórios.

Durante o percurso da pesquisa, identificamos que a estratégia do capital para extrair mais valor se dá ao tornar o valor invisível (ANTUNES, 2018), isso se aplica na cadeia de valor global em que estão inseridos os arranjos pesquisados. 
O trabalho do jornalista ao tratar a informação, fazer a mediação entre acontecimentos e um público mais amplo é utilizado pelas plataformas para ampliar seus arquivos com esse tipo diferenciado de matéria que só pode ser produzida com a participação de um profissional. Além disso, os veículos jornalísticos geram volume maior de dados para essas empresas que expropriam o valor gerado pelo trabalho digital.

As formas de extração de valor feitas a partir de sistema privado de governança e gestão, baseada em ampla coleta de dados e interações “datificadas' são pontos a serem explorados de forma aprofundada e articulada às discussões atuais sobre "capitalismo de plataforma" (LOBO, 2014; SRNICEK, 2017) ou "capitalismo de vigilância" (ZUBOFF, 2015).

O que já sabemos é que o "capitalismo de plataforma é a protoforma do capitalismo"89 ao seguir os objetivos originários do capital de gerar lucro, controlar mercados, concentração extrema de renda e, consequentemente, desigualdade social através de um modelo econômico que captura a produção massiva de dados.

Compreender e ampliar a discussão sobre o trabalho digital e os espaços virtuais de trabalho são necessários para apreender mudanças desses tempos de transição do modo capitalista de produção e os impactos nas relações sociais como forma de interpretar e gerar mudanças estruturais na realidade.

Esses apontamentos evidenciam que regular a comunicação é preciso. Com o crescimento desses sites de redes sociais cuja condensação de tráfego de usuários tem servido para impactar processos democráticos, a proposta de regulamentação da comunicação também se complexifica.

Além de estabelecer normas para evitar o monopólio e a propriedade cruzada de meios de comunicação das cinco famílias que detém as principais corporações de mídia no Brasil, é necessário elaborar ajustamentos para, inclusive, fazer retornar o valor do trabalho do jornalista exercido nesses espaços da internet.

Por fim, consideramos fundamental discutir a pesquisa com os arranjos que foram objetos desta análise para que as questões principais apontadas na pesquisa circulem, possam adquirir novas dimensões, gere novas dúvidas e estudos sobre o tema.

\footnotetext{
${ }^{89}$ Ricardo Antunes (2018). Informação verbal coletada em sala de aula na disciplina Sociologia do Trabalho I, na Unicamp.
} 
Retornar para a sociedade a produção científica é uma das formas de combater o produtivismo e a disputa por visibilidade acadêmica. O que precisa ser aparente e exibido é o sentido da produção, o objeto, procedimentos, considerações da pesquisa e o conhecimento fruto dos embates teóricos e metodológicos. Ter esses objetivos é uma importante bússola para o pesquisador. 


\section{Referências Bibliográficas}

ABRAMO, PERSEU. Padrões de manipulação da grande imprensa. São Paulo. Fundação Perseu Abramo, 2008.

ABRAÃO, Cláudia. Entrevista número 8. Entrevistadora. Ana Flávia Marques da Silva. 2018.

ALMEIDA, Guilherme. Entrevista número 4. Entrevistadora. Ana Flávia Marques da Silva. 2018.

AMARAL, Tarso. Entrevista número 5. Entrevistadora. Ana Flávia Marques da Silva. 2018.

ANDERSON, C.W.; BELL, Emily; SHIRKY, Clay. Jornalismo Pós-Industrial: adaptação aos novos tempos. Tradução Ada Felix. Revista de Jornalismo da ESPM, São Paulo, ano 2, n 5 , p. $30-89,2013$.

ANDERSON, CW. Beyond journalism in the present tense. Cambridge, 2014. Disponível em: https://www.niemanlab.org/author/canderson/Acesso em: 16 mar 2017.

ALTHUSSER, Louis. Aparelhos ideológicos de Estado. Nota sobre os Aparelhos Ideológicos de Estado. Graal. RJ. 2001

ALVES, GIOVANNI. Trabalho e Subjetividade: o espírito do toyotismo na era do capitalismo manipulatório. São Paulo. Boitempo. 2011.

ANTUNES, R. Os sentidos do trabalho: ensaio sobre a afirmação da negação do trabalho. São Paulo: Editora Boitempo.1999.

e ALVES. G. As mutações no mundo do trabalho na era da mundialização

do capital. Disponível em http://www.scielo.br/pdf/es/v25n87/21460.pdf acesso em 20/09/2016

ATTON, Chris. Alternative Media. London: Sage, 2002.

ASSIS, Thiago. Entrevista número 13. Entrevistadora. Ana Flávia Marques da Silva. 2018.

BAKHTIN, MIKHAIL; VOLOCHINOV Marxismo e filosofia da linguagem. $11^{\mathrm{a}}$ edição. São Paulo: Editora HUCITEC, 2014.

BAKHTIN, MIKHAIL. Teoria do romance II: As formas do tempo e do cronotopo. São Paulo. Editora 34. 2018.

BARBOSA, Marialva. História cultural da imprensa: Brasil 1900-2000. Rio de Janeiro: Mauad X. 2007.

BASSO, Pietro. Tempos modernos, jornadas antigas. Vidas de trabalho no início do speculo XXI. Campinas. Editora Unicamp. 2018.

BENKLER, Y. Sharing nicely: On shareable goods and the emergence of sharing as a modality of economic production. The Yale Law Journal. 2004 
BIANCHI, Graziela In Metodologias de Pesquisa em Comunicação: olhares, trilhas e processos. Porto Alegre. Sulina. 2006.

BRANDÃO, Helena H. Nagamine. Introdução à Análise do Discurso. Campinas: Unicamp, 1991.

BOTSMAN, R.; ROGERS, R. What's mine is yours: The rise of collaborative consumption. New York: Harper Business. 2010

BREED, Warren. Controle social da redação: uma análise funcional In.: TRAQUINA, Nelson (Org.). Jornalismo: Questões, teorias e estórias. [s.1.] Vega, 1993.

BOURDIEU, Pierre O Campo científico. In: Pierre Bourdieu. SãoPaulo: Ática. 1983

BROOKE, Nigel. Os 40 anos da Fundação Ford no Brasil. São Paulo. Edusp. 2002

CANCLINI, Néstor García. O mundo inteiro como lugar estranho. Edusp. SP. 2016.

Carta do IV Fórum Mundial de Mídia Livre. Túnis, 2013, Disponível em http://www.intervozes.org.br/direitoacomunicacao/?p=28862 Acesso em 18/03/2014

CASTELLS, Manuel. A sociedade em rede. São Paulo: Paz e Terra, 2017. 18 edição

CHEPTULIN, Alexandre. A Dialética Materialista: categorias e leis da dialética. Ed. AlfaOmega, SP. 2004

CAPPELLI P; KELLER J. Classifying work in the new economy. Acad. Manag. 2013

CARDOSO, Univaldo Coelho. APL: arranjo produtivo local. Brasília. Biblioteca do Sebrae 2014

CERAVOLO, Haroldo; TERRA, Marina. O mundo em movimento. São Paulo. Ed. Alameda. 2014

COHEN, Julie E. The biopolitical public domain: the legal construction of the surveillance economy. Philosophy \& Technology, p. 1-21, 2017.

CORREA, Paulo. Entrevista número 11. Entrevistadora. Ana Flávia Marques da Silva. 2018.

COUTINHO, Eduardo Granja. Comunicação e contra-hegemonia. Rio de Janeiro. Editora UFRJ. 2008.

CRUZ, Olímpio. Entrevista número 10. Entrevistadora. Ana Flávia Marques da Silva. 2018.

DARDOT, P. E LAVAL, C. A nova razão do mundo: ensaio sobre a sociedade neoliberal. São Paulo: Editora Boitempo, 2016.

DESLANDES, Gabriel Carin; AFFONSO, Lucas Torres de Oliveira. Abolição da Escravatura sob a Prensa da Gazeta de Notícias. Trabalho apresentado no Grupo de Trabalho História da Mídia Impressa no III Encontro Regional Sudesse de História da Mídia. 2014. Disponível em www.gthistoriamidiaimpressa_gabriel_deslandes.pdf. Acesso 01/6/2017 
DOWNING, John.D.H., Mídia Radical: rebeldia nas comunicações e movimentos sociais. Ed. Senac. SP. 2002

DEL ROIO, Marcos (org). Gramsci - periferia e subalternidade. Edusp. SP. 2017.

FAÏTA, Daniel. A análise de práticas linguageiras e situações de trabalho: uma renovação metodológica imposta pelo objeto. In: SOUZA E SILVA, M. Cecília P., FAÏTA, Daniel. (orgs.) Linguagem e trabalho. Construção de objetos de análise no Brasil e na França. São Paulo: Cortez, 2002.

ESTELLÉS-AROLAS, E., \& GONZÁLEZ-Ladrón-de-Guevara, F. Towards an integrated crowdsourcing definition. Journal of Information Science, 2012. Disponível em https://journals.sagepub.com/doi/abs/10.1177/0165551512437638 Acesso em 03/03/2019

FELÍCIO, JOÃO. Entrevista número 15. Entrevistadora. Ana Flávia Marques da Silva. 2018.

FERREIRA, Maria Nazareth. A imprensa operária no Brasil. Ed. Ática. SP. 1988

FESTA, Regina; e LINS DA SILVA, Carlos Eduardo. Comunicação popular e alternativa no Brasil. São Paulo: Paulinas, 1986.

FESTA, Regina. Movimentos sociais, comunicação popular e alternativa. In: FESTA, Regina; e LINS DA SILVA, Carlos Eduardo. Comunicação popular e alternativa no Brasil. São Paulo: Paulinas, 1986.

FÍGARO, Roseli A. Comunicação e trabalho. Estudo de recepção: o mundo do trabalho como mediação da comunicação. São Paulo: Anita Garibaldi/Fapesp, 2001. 2008. Relações de comunicação no mundo do trabalho. São Paulo: AnnaBlume,

_. Atividade de Comunicação e trabalho. Revista Trabalho, Educação Saúde. Fiocruz, rio de Janeiro, v. $6 \quad$ n. $\quad 1 ., \quad 2008$.

Comunicação e Trabalho: binômio teórico produtivo para as pesquisas de recepção. Mediaciones Sociales. Revista de Ciencias Sociales y de la Comunicación, $\mathrm{n}^{\mathbf{0}} 4$, primer semestre de 2009, pp. 23-49. ISSN electrónico: 1989-0494. Universidad Complutense de

Madrid.

. Estudo de Recepção e Ergologia: novos desafios teórico-metodológicos. ECompós, Vol. 12, no 3 (2009) E-ISSN 1808-2599

As relações de comunicação e as condições de produção no trabalho de jornalistas em arranjos econômicos alternativos às corporações de mídia. São Paulo. Fapesp. 2018

FILOMENA, Maria. Entrevista número 6. Entrevistadora. Ana Flávia Marques da Silva. 2018.

FIORUCCI, Rodolfo. A nova geração do jornalismo crítico: mídia alternativa. Revista Diálogos, v. 15, n. 2, Maringá, maio / agosto 2011. Disponível em http://periodicos.uem.br/ojs/index.php/Dialogos/article/view/36208 Acesso em: 17 de janeiro de 2015. 
FOSCHINI, Ana Carmem; TADDEI, Roberto Romano. Jornalismo Cidadão: você faz a Notícia. Overmundo/Coleção Conquiste a Rede, São Paulo, 2006

FRANCISCATO, Carlos Eduardo. A tecnologia móvel como plataforma de inovação no jornalismo de cidades. Revista Líbero. Revista eletrônica do Programa de Mestrado em Comunicação da Faculdade Cásper Líbero. 2018 Disponível http://seer.casperlibero.edu.br/index.php/libero/article/view/952/973 Acesso em 08/05/2019

FUCHS, Christian; SANDOVAL, Marisol. Trabajadores Digitales del mundo, uníos! Un marco para teorizar críticamente y analizar el trabajo digital. Buenos Aires. Hipertexto. 2015. Disponível em http://www.triple-c.at Acesso em 25/04/2018

GALVÃO, Mônica. Entrevista número 7. Entrevistadora. Ana Flávia Marques da Silva. 2018.

GEERTZ, C. Local Knowledge: Further Essays in Interpretative Anthropology. Nova York. Basic Books. 1983.

GENRO FILHO, Adelmo. O Segredo da Pirâmide: para uma teoria marxista do jornalismo. Florianópolis: Insular, 2012.

GIDDENS, Anthony; BECK, Ulrich e LASH, Scott (1997). Modernização reflexiva. São Paulo: Ed. UNESP.

GIL, Antonio Carlos. Métodos e Técnicas de Pesquisa Social. Ed. Atlas. SP. 1999.

GOMES, Luiz. Entrevista número 3. Entrevistadora. Ana Flávia Marques da Silva. 2018.

GORGEN, James. Sistema central de mídia: proposta de um modelo de comunicação no Brasil. Dissertação de mestrado. Faculdade de Biblioteconomia e Comunicação. Universidade Federal do Rio Grande do Sul Disponível em http://hdl.handle.net/10183/17166. Acesso em 02/02/2018

GRACILIANO, Luiz. Entrevista número 14. Entrevistadora. Ana Flávia Marques da Silva. 2018.

Gramsci, Antonio. Cadernos do Cárcere. 6 Volumes. Civilização Brasileira. RJ. 2006.

GRINBERG, Máximo Simpson (org). A Comunicação Alternativa na América Latina. Vozes. Petropólis. 1987.

GRUPPI, Luciano. O conceito de hegemonia em Gramsci. Ed. Graal. RJ. 1978.

GRETCHEN, M. Spreitzer; CAMERON, Lindsey; GARRET, Lyndon. Alternative Work Arrangements: Two Imagens of the new world of work, 2017. The Annual Review of Organizational Psychology and Organizational Behavior. https://doi.org/10.1146/annurevorgpsych- 032516-113332, disponível em orgpsych.annualreviews.org. Acesso: em 12 de março de 2019

Guevara, E. C. O Partido Marxista-Leninista. In A. Bogo (Ed.), Teoria da organização política. São Paulo, SP: Expressão Popular. 2010.

HARVEY, David. Condição pós-moderna. São Paulo: Loyola, 1992. 
KARSENTY, L., LACOSTE, M. Comunicação e Trabalho. In: FALZON, P. (ed.) Ergonomia. São Paulo: Blucher, 2007.

HAUBRICH, Alexandre. Mídias Alternativas em Porto Alegre: processos comunicativos, midiatização digital e cidadania na perspectiva de seus comunicadores. Dissertação de Mestrado. Universidade do Vale do Rio dos Sinos. 2016. Disponível em http://www.repositorio.jesuita.org.br/handle/UNISINOS/5226. Acesso em 19/10/2017.

HEWLET, Ann Sylvia; LUCE, Buck Carolyn. Extreme Jobs: the dangerous allure of the 70 hour workweek. Harvard Business Review. Número 12. 2006

HESMONDHALGH, David, BAKER, Sarah. Creative labour. Media work in three cultural industries. New York: Routledge, 2011.

HJARVARD, S. Midiatização: conceituando a mudança social e cultural. Matrizes, V. 8 No 1 jan./jun. São Paulo. Brasil. 2014.

HOPKINS, T.; WALLERSTEIN, I. Commodity chains in the world economy prior to 1800. Review. 1986.

HOWE, J., \& Robinson, M. (2005, June). The rise of crowdsourcing. 2005

LAGE, Nilson. Ideologia e técnica da notícia. $4^{\mathrm{a}}$ ed. Série Jornalismo a Rigor. Vol. 5. Florianópolis. Insular, 2002

IANNI, Otavio in BACEGA, M. A. (Org). Gestão de Processos Comunicacionais. São Paulo: Editora Atlas, 2002.

KAGANER, E., CARMEL, E., HIRSCHHEIM, R., \& OLSEN, T. Managing the human cloud. MIT Sloan Management Review. 20012.

KAPLÚN, Gabriel. Comunicación educativa y comunitaria: construcción de nuevos vínculos y sentidos en y desde la universidad. Em: Comunicación para el desarrollo: una herramienta para el cambio social y la participación. Oficina Regional de Ciencia de la UNESCO para América Latina y el Caribe: Uruguay, 2010. Disponível em https://www.cmlk.cu/article/gabriel-kaplun /. Acesso em: 10 de janeiro de 2018.

KAPLÚN, Gabriel. La comunicación comunitária en América Latina. Buenos Aires (Argentina): Facultad de Ciencias Sociales de Buenos Aires, 2012. Disponível em del-taller-de-comunicacic3b3n-comunitaria-2012.pdf>. Acesso em: 3 de novembro de 2015.

KUCINSKI, Bernardo. Jornalistas e revolucionários: nos tempos da imprensa alternativa. São Paulo: Scritta, 2011

JENKINS, Henry. Cultura da Convergência. Lisboa: Editora Aleph, 2008 .; GREEN, J; FORD, S. Cultura da Conexão: criando valor e significado por meio da mídia propagável. São Paulo: Aleph, 2014. 
LABRIOLA, Antonio. Essays on the Materialist Conception of History. Editora Atena. 1956

LE CAM, Florence. Photographs of newsrooms: From the printing house to open space offices. Analyzing the transformation of workspaces and information production. Manchester. Sage. 2014. Disponível em jou.sagepub.com. Acesso em: 17/12/2017

LENIN, Vladimir Ilitch. Materialismo e Empiriocriticismo. Ed. Avante. Lisboa. 1982

As duas táticas in Obras Escolhidas. Tomo1. Ed. Avante. Lisboa.

1984

ENGELS, Friedrich. Anti-During. $2^{a}$ ed. Paz e Terra. Rio de Janeiro. 1979.

Dialética da Natureza. 1952, Disponível em

https://www.marxists.org/portugues/marx/1876/mes/macaco.htm. Acesso em 18/11/2016

LIMA, Venício A. de. Comunicação, poder e cidadania. Rastros - Revista do Núcleo de Estudos de Comunicação. Ano VII, N. 7, 2006, p. 8-16.

Liberdade de expressão x Liberdade da imprensa - Direito à comunicação e democraca. Publisher Brasil, 2012a.

e GUIMARÃES, Juarez. Liberdade de expressão: as várias faces de um desafio.

São Paulo. Ed. Paulus. 2013

Regulação das comunicações. São Paulo. Ed. Paulus. 2014

A de. Liberdade de Expressão x Liberdade de Imprensa. Direito à Comunicação e Democracia. São Paulo: Publisher Brasil, 2010.

de. Comunicação, poder e cidadania. Rastros - Revista do Núcleo de Estudos de Comunicação. Ano VII, N. 7, 2006.

LEONTIEV, Alex. O desenvolvimento do psiquismo. Lisboa: Livros Horizonte. 2004.

LIMA, Cláudia do Carmo Nonato. Jornalistas, blogueiros, migrantes da comunicação: em busca de novos arranjos econômicos para o trabalho jornalístico com maior autonomia e liberdade deexpressão. 2015.250 f. Tese (Doutorado em Ciências da Comunicação) -Escola de Comunicações e Artes, Universidade de São Paulo, 2015 Disponível em: http://www.teses.usp.br/teses/disponiveis/27/27152/tde-26062015112522/pt-br.php23 acesso em 18/08/2016

LOJKINE, J. A Revolução Informacional. São Paulo. Cortez, 1995

LOPES, Maria Immacolata V. Pesquisa em comunicação. São Paulo: Loyola, 12 ed. 2014 MAINGUENEAU, D. Análise de textos de comunicação. São Paulo: Cortez, 2001

MALDONADO, Alberto Efendy et. Al. Perspectivas metodológicas em comunicação: desafios na prática investigativa. João Pessoa: UFPB, 2008. 
MARTÍN-BARBERO, Jesús (2009). Uma aventura epistemológica. MATRIZes 2, Ano 2. Entrevista realizada por Maria Immacolata Vassallo de Lopes.

MATTELART, Armand e MATTELART, Michèle História das teorias da Comunicação. São Paulo: Loyola. 1998..

MARX, Karl. Manuscritos econômico-filosóficos. Lisboa: Edições 70, 1993.

O Capital. Crítica da economia política. Vol I, livro Primeiro, O processo de produção do Capital. Tomo I. São Paulo: Nova Cultural, 1985. (Coleção Os Economistas).

ENGELS, F. A ideologia alemã. São Paulo; Hucitec. 1985.

Cultura, arte e literatura. Textos escolhidos. São Paulo: Expressão popular, 2010, p. 97 a 101,113 a 117; 151 a 156.

1983

. Contribuição à Crítica da Economia Política. 2aed. Martins Fontes. SP.

. O 18 Brumário de Luís Bonaparte. Boitempo. SP. 2011

. Capital I, II e II. São Paulo. Boitempo. 2017

MENDES, Márcio. Entrevista número 1. Entrevistadora. Ana Flávia Marques da Silva. 2018.

MENDES, Nicole. Entrevista número 16. Entrevistadora. Ana Flávia Marques da Silva. 2018.

MORAES, D. O capital da mídia na lógica da globalização. In: Por uma outra comunicação: mídia, mundialização cultural e poder. Rio de Janeiro, São Paulo: Record, 2005, p. 187-216.

Crítica da Mídia e Hegemonia Cultural. Rio de Janeiro: Mauad X, 2016

. (org.). Por uma outra comunicação: mídia, mundialização cultural e poder. Rio de

Janeiro: Record, 2003. (org.). Sociedade midiatizada. Rio de Janeiro: Mauad, 2006

MOSCO, Vincent; MCKERCHER, Catherine. The Laboring of Communication. Will Knowledge Workers of the World Unite? Lanham. Lexington Books. 2009.

MOROZOV, Evgeny. To save everything, click here: The folly of technological solutionism. New York. Public Affairs. 2014.

. Big Tech. A ascensão dos dados e a morte da política. São Paulo. Ubu editora.

2018.

MOURÃO, Patricia. Entrevista número 2. Entrevistadora. Ana Flávia Marques da Silva. 2018

NEUMANN, Laurício. Educação e Comunicação Alternativa. Ed. Vozes. RJ, 1990. 
NOUROUDINE, Abdallah. A linguagem: dispositivo revelador da complexidade do trabalho. In: SOUZA E SILVA, M. Cecília P., FAÏTA, Daniel. (orgs.) Linguagem e trabalho. Construção de objetos de análise no Brasil e na França. São Paulo: Cortez, 2002.

OHNO, Taichi. O sistema Toyota de produção: além da produção em larga escala. São Paulo. Bookman. 1997.

OTRE, Maria Alice Campagnoli. A pesquisa acadêmica sobre comunicação popular, alternativa e comunitária no Brasil: análise das teses e dissertações produzidas nos programas de pós-graduação em comunicação 1972-2012. Tese de Doutorado defendida em 2015. Universidade Metodista. Disponível em http://tede.metodista.br/jspui/bitstream/tede/1496/2/Maria\%20Otre.pdf. Acesso em 05/10/2017

PEREIRA, Raimundo. Vive a Imprensa alternativa. Viva a imprensa alternativa! In

PERUZZO, Cicilia M. K. A comunicação no desenvolvimento comunitário e local, comcibercultur@. Anais do XXI Encontro Anual da Compós. Juiz de Fora (MG): Compós, 2012.

PERUZZO, Cicilia Maria Krohling. Aproximações entre a comunicação popular e comunitária e a imprensa alternativa no Brasil na era do ciberespaço. Revista Galáxia, n.17, São Paulo, 2009. Disponível em Acesso em:19/05/2017.

PERUZZO, Cicilia Maria Krohling. Comunicação Popular em seus aspectos teóricos. PERUZZO, Cicilia Maria Krohling. Comunicação nos movimentos populares: a participação na construção da cidadania. 2a edição. Petrópolis: Editora Vozes, 1998.

PERUZZO, Cicilia M. K. Rádios Comunitárias no Brasil: da desobediência civil e particularidades às propostas aprovadas na CONFECOM. XIX Encontro Anual da Compós. Rio de Janeiro, 2010. Disponível em rio.br/media/g6_cicilia_peruzzo.pdf >. Acesso em: 20 de outubro de 2015.

PERUZZO, Cicilia Maria Krohling. Revisitando os Conceitos de Comunicação Popular, Alternativa e Comunitária. XXIX Congresso Brasileiro de Ciências da Comunicação. UnB. Brasília, $2006 . \quad$ Disponível em http://www.portcom.intercom.org.br/pdfs/116338396152295824641433175392174965949.pd f>. Acesso em: 19 de janeiro de 2015.

PORTO, Mauro. Revista ComPolítica.Volume 2. Entrevista de Aldé, Alessandra. 2011

POUPART,Jean et al. A pesquisa qualitativa. Enfoques epistemológicos e (2008).

PORTER, M. Competitive advantage: Creating and sustaining superior performance. New York. 1985

RAMONET, I. A explosão do Jornalismo: das mídias de massas à massa de mídias. São Paulo: Publisher Brasil, 2012 
RAMOS, Daniela O. Formato: condição para a escrita do jornalismo digital de bases de dados. Uma contribuição da Semiótica da Cultura. Tese de Doutorado. Escola de Comunicações e Artes da Universidade de São Paulo, 2012.

RECKWITZ, A. Toward a theory of social practices: a development in social theorizing. European Journal of Social Theory, 2002.

REIS, Mariana Ferreira. Comunicação, Cultura e mobilização comunitária. Curitiba. Appris. 2018

RODRIGUES, Edgar. Sindicalismo e socialismo no Brasil. Ed. Laemert, 1969.

RODRIGUES, Albertino. Sindicato e desenvolvimento no Brasil. Ed. Difel. 1968

ROSENBAUM, S. (2011) Curation nation. Why the future of context is context. NY: McGraw Hill.

RUBIN, Isaak Illich. A teoria marxista do valor. São Paulo. Editora Brasiliense. 1980.

SAAD, Elizabeth; RAPOSO, João Francisco. Prosumers: colaboradores, cocriadores e influenciadores. Revista Comunicare. Volume 17. Disponível em https://casperlibero.edu.br/wp-content/uploads/2017/09/Artigo-6-Communicare-17-

Edi\%C3\%A7\%C3\%A3o-Especial.pdf Acesso em 10/01/2019

SADER, Emir. Apresentação. In: Karl \& ENGELS, Friedrich. A Ideologia Alemã. São Paulo: Boitempo Editorial, 2010

SANTOS, LEONARDO. Entrevista número 12. Entrevistadora. Ana Flávia Marques da Silva. 2018.

SILVA, Mariana da Rosa. Tensões entre o alternativo e o convencional: organização e financiamento nas novas experiências de jornalismo no brasil. Dissertação de mestrado. Universidade Federal de Santa Catarina. Disponível em https://repositorio.ufsc.br/handle/123456789/185627. Acesso em: 11/03/2018

SILVA, Ana Cláudia. Entrevista número 9. Entrevistadora. Ana Flávia Marques da Silva. 2018.

SILVERMAN, David. Qualitative research: meanings or practices. Information Systems Journal, v. 8.1985.

SLEE, TOM. Uberização: a nova onda do trabalho precarizado. São Paulo. Editora Elefante. 2017.

SCHERER-WARREN, I. "Redes sociales y de movimientos en la sociedad de la información”, Nueva Sociedad, Caracas, n¹96, março-abril de 2005, p. 77-92.

SRNICEK, Nick. Platform capitalism. John Wiley \& Sons, 2017.

SODRÉ, Nelson Werneck. História da Imprensa no Brasil. EdiPucRS. Rio Grande do Sul. 2011 
SCHAFF, Adam. Linguagem e conhecimento. Coimbra: Almedina, 1976. SCHWARTZ, Yves. DURRIVE, L. Trabalho \& Ergologia. Rio de Janeiro: Eduff, 2008. SCHWARTZ, Yves. Circulações, dramáticas, eficácias da atividade industriosa. Revista Trabalho, Educação, Saúde. Fiocruz, 2 (1), 33-55, 2004. http://www.revista.epsjv.fiocruz.br/

SOMEKH, Bridget e LEWIN, Cathy (orgs) Teoria e Métodos de Pesquisa Social. Ed. Vozes. Petrópolis. 2015

SODRÉ, Muniz. A ciência do comum. Notas para o método comunicacional. Petrópolis: Vozes, 2014.

Antropológica do Espelho: uma teoria da comunicação linear e em rede. 7. ed. Petrópolis, RJ: Vozes, 2012.

TUCHMAN, Gay. Making News by Doing Work: Routinizing the Unespected. Americam Journal of Sociology. 1979

VALVERDE, M. E. G. L. (1986). Militância e poder: Balizas para uma genealogia da militância (Dissertação de mestrado apresentada ao Departamento de História, Universidade Estadual de Campinas, SP, Brasil). Recuperado em http://www.bibliotecadigital.unicamp.br/document/?view=000017675

VAN DOORN, N. (2014). The neoliberal subject of value: Measuring human capital in information economies. Cultural Politics,

VAQUERO, L. M., Rodero-Merino, L., Caceres, J., \& Lindner, M. (2008). A break in the clouds: Towards a cloud definition. ACM SIGCOMM Computer Communication Review, 39

VISIBELLI, Janaina. Conglomerados Midiáticos Regionais: os meios de comunicação como meios de produção na territorialização do capital. Tese de doutorado. ECA. USP. Disponível http://www.teses.usp.br/teses/disponiveis/27/27152/tde-24052019-102718/ptbr.phpem Acesso em 07/07/2019

VYGOTSKI, L.S. Pensamento e linguagem. 3.ed. São Paulo: Martins Fontes, 2005.

WALKER, R. The conduct of education case study: Ethics, theory and procedures. 1974 [Reimp, em Torrance, H.(ed) 2010. The Sage Handbook of Qualitative Research Methods in Education. Londres: Sage

WILLIAMS, Raymond. Marxismo y literatura. Buenos Aires: las Cuarenta, 1979. Cultura e materialismo. São Paulo: Ed. Unesp, 2011.

WOLF, Mauro. Teorias da comunicação. 5. ed. Lisboa: Presença, 2012.

YIN, Robert K. Estudo de caso: planejamento e métodos. 4. ed. Porto Alegre: Bookman, 2010.

ZUBOFF, Shoshana. Big other: surveillance capitalism and the prospects of an information civilization. Journal of Information Technology, v. 30, n. 1. 2015 


\begin{abstract}
ANEXOS
Os arquivos com as entrevistas encontram-se em mídia em formato áudio e texto juntamente com o roteiro da entrevista.
\end{abstract}

